\title{
Sequenzierung, RFLP-Analyse und STR-Genotypisierung alter DNA aus archäologischen Funden und historischen Werkstoffen
}

\author{
Dissertation \\ zur Erlangung des Doktorgrades \\ der Mathematisch-Naturwissenschaftlichen Fakultäten \\ der Georg-August-Universität zu Göttingen
}

vorgelegt von

Joachim A. Burger

aus Aschaffenburg

Göttingen 2000 
D 7

Referent:

Prof. Dr. B. Herrmann

Korreferent:

Prof. Dr. H.-J. Fritz

Tag der mündlichen Prüfung: $\quad$ 26.04.2000 
Diese Arbeit wurde am Institut für Zoologie und Anthropologie der Universität Göttingen, Abteilung für Historische Anthropologie und Humanökologie, angefertigt.

Die Untersuchungen wurden aus Mitteln des BMBF gefördert. 


\section{Inhaltsverzeichnis}

$1 \quad$ Einleitung .............................................................................................. 1

$2 \quad$ Fragestellung und Zielsetzung..................................................................... 4

2.1 Restaurierung, Konservierung und Denkmalpflege .........................................5

2.2 Technik- und Materialkunde ............................................................................5

$2.3 \quad$ Kunstgeschichte .........................................................................................................

2.4 Pharmazie und Medizin .................................................................................6

2.5 Anthropologie und Archäologie............................................................................6

2.6 Handschriftenkunde und Kodikologie..............................................................7

2.6.1 Exkurs: Kurze Geschichte der Beschreibstoffe ................................................ 8

3 Bisherige Arbeiten über DNA aus Sachüberresten ........................................ 10

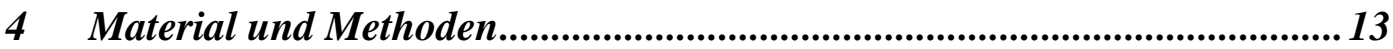

4.1 Methodenüberblick.........................................................................................13

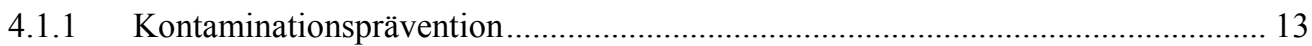

4.1.2 Voruntersuchung, Probennahme, Homogenisieren und Extraktion....................... 14

4.1.3 DNA-Extraktion ................................................................................ 15

4.2 Von der Entnahme zur Extraktion ..................................................................17

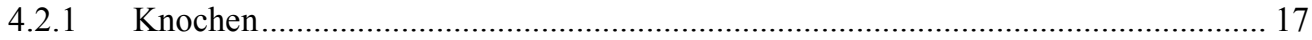

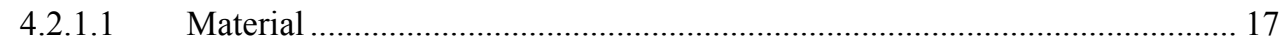

4.2.1.2 Methoden ................................................................................................. 18

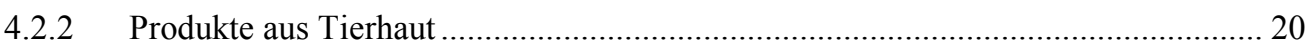

4.2.2.1 Pergament............................................................................................ 20

4.2.2.2 Getrocknete Haut ............................................................................... 21

4.2.2.3 (Buch-) Leder .................................................................................... 24

4.2.2.4 Archäologische Leder und stark gegerbte Buchleder ................................ 25

4.2.3 Leime, Bindemittel und Öle....................................................................... 27

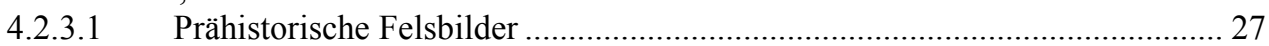

4.2.3.2 Historische Werkstoffe........................................................................ 28

4.2.4 Inhaltsreste (prä)historischer Behälter ........................................................ 30

4.2.4.1 Material ........................................................................................ 30

4.2.4.2 Methoden ..................................................................................... 31

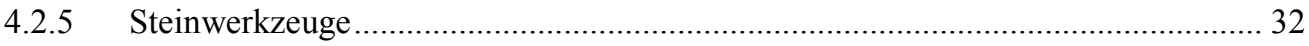

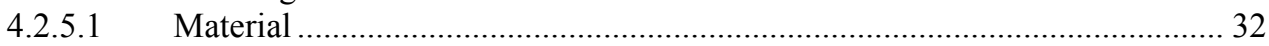

4.2.5.2 Methoden ............................................................................................ 32

4.2.6 Archäologische Textil- und Pflanzenfunde .............................................. 33

4.2.7 Positivkontrollen .................................................................................... 33

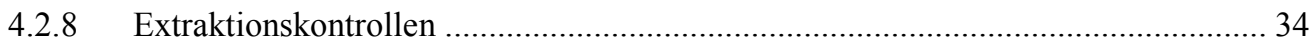

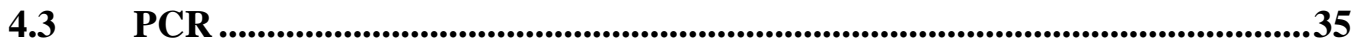

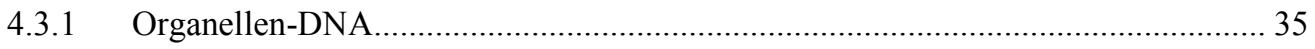

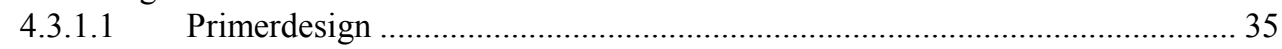

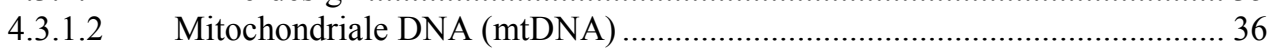

4.3.1.3 Chloroplasten-DNA (cpDNA) - Der rbcL locus ....................................... 41

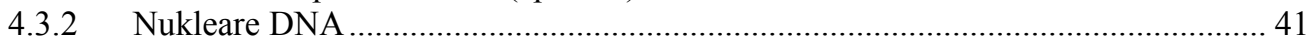


4.4 Restriktionsfragment-Längenpolymorphismus von PCR-Produkten (PCR-

RFLP)

4.4.1

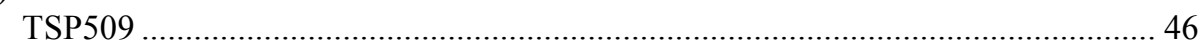

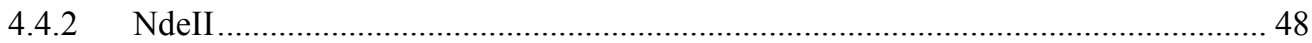

4.4.3 Duplex DdeI und NdeII ....................................................................................... 48

4.5 Agarose Gelelektrophorese .................................................................................52

4.6 Aufreinigung von PCR-Produkten....................................................................552

4.7 DNA Cycle Sequencing von PCR-Produkten................................................52

4.8 Kapillar-Elektrophorese für die DNA-Sequenzierung....................................53

4.9 Kapillar-Elektrophorese für die Fragmentlängendetektion .......................54

4.10 Plattengelelektrophorese für die Fragmentlängendetektion.......................54

4.11 Plattengelelektrophorese für die Sequenzierung .........................................55

4.12 Erfassung und Auswertung von DNA-Sequenzdaten .................................55

4.13 Erfassung und Auswertung von Microsatelliten-DNA-Daten .....................55

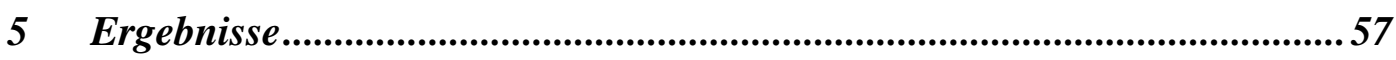

$5.1 \quad$ Knochen ..............................................................................................................................55

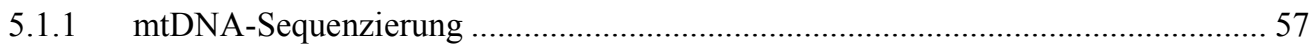

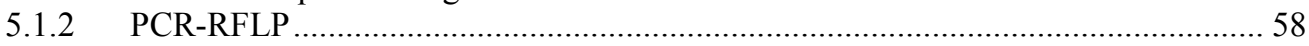

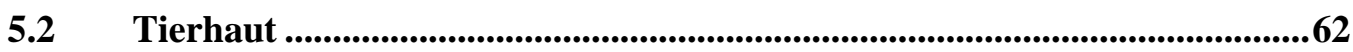

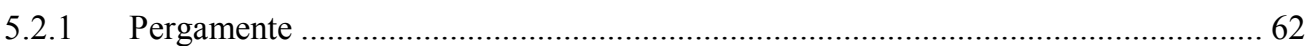

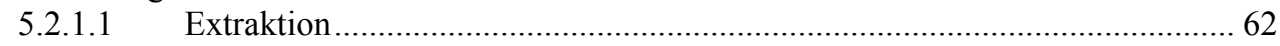

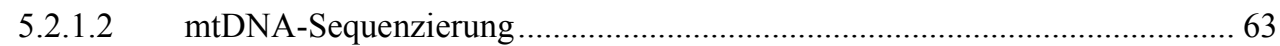

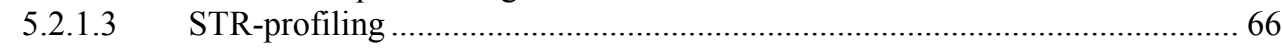

5.2.1.4 Allelvergleich mit modernen Populationen...................................................... 68

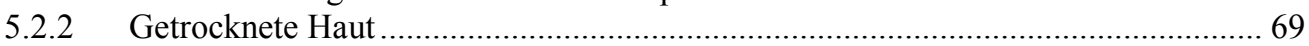

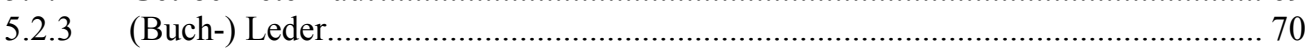

5.2.4 Archäologische Leder und stark gegerbte Buchleder ........................................... 71

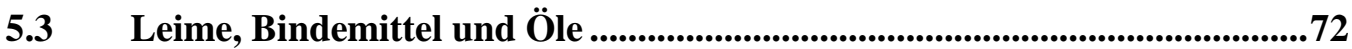

5.3.1 Prähistorische Felsbilder................................................................................. 72

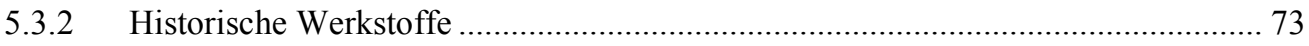

5.4 Inhaltsreste (prä)historischer Behälter .................................................................74

5.4.1 Die keltische Tierhaut von Dürrnberg/Österreich.................................................. 74

5.4.2 Mittel- und südamerikanische Behälter des Völkerkundemuseums in Berlin .......... 75

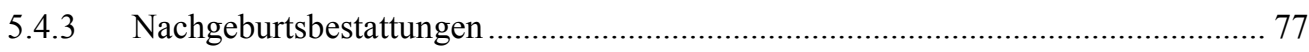

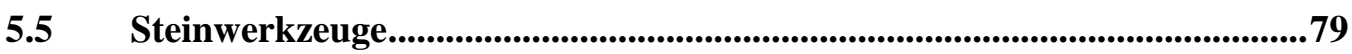

5.6 Archäologische Textil- und Pflanzenfunde..................................................80

5.7 PCR- und Extraktionskontrollen, Kontaminationen, Multiple Sequenzen ...81

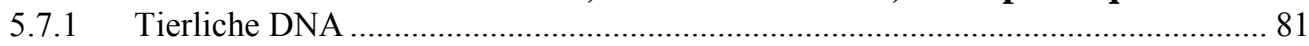

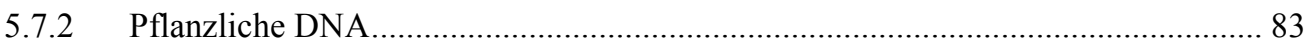

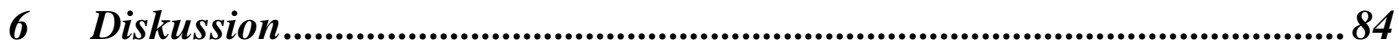

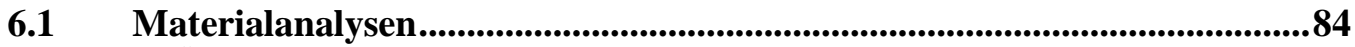

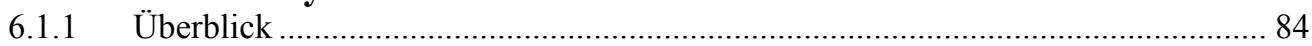

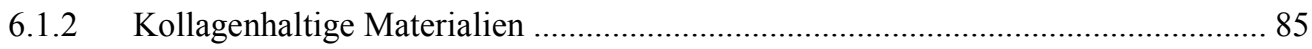

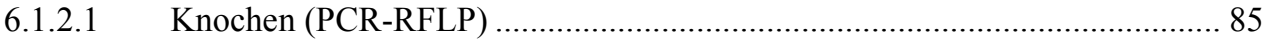

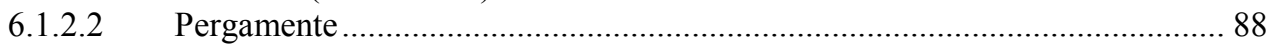




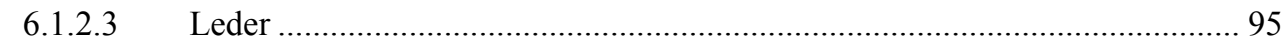

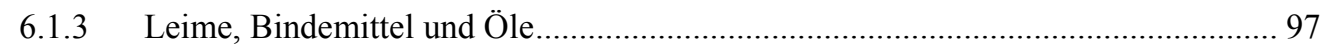

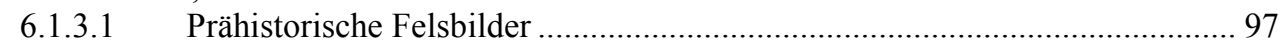

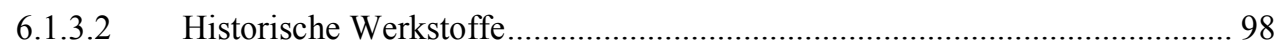

6.1.4 Inhaltsreste (prä)historischer Behälter ................................................................ 99

6.1.5 Archäologische Kleinfunde (Textile, Pflanzen, Leder) ………............................... 102

6.1.6 Ungeschützte Materialien (Felsbilder, Steinwerkzeuge) ....................................... 104

6.2 Methodendiskussion .....................................................................................106

6.2.1 Strategien zum Primerdesign - Theorie und Praxis................................................ 106

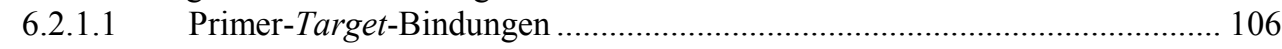

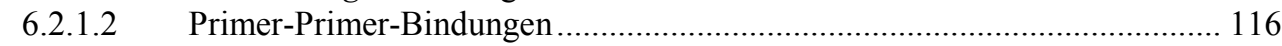

6.2.2 Kontaminationen und Gemische.................................................................. 117

6.2.2.1 Kontamination von Chemikalien und Reaktionsgefäßen ............................. 117

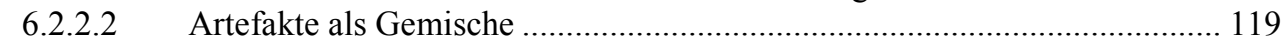

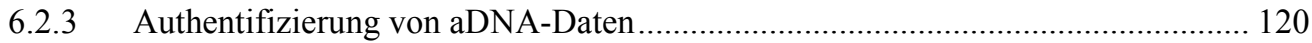

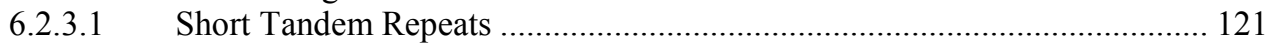

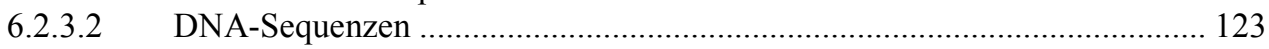

6.3 Zusammenfassende Bewertung und Perspektiven.........................................128

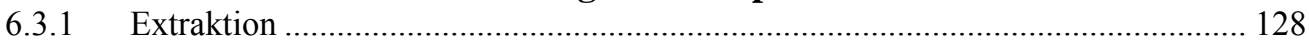

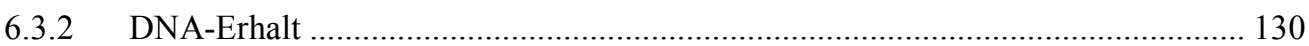

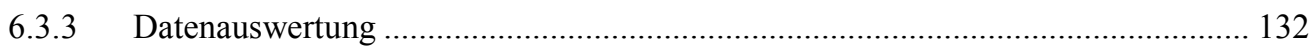

6.3.3.1 Speziesidentifizierung von Tieren durch mtDNA-Sequenzierung und PCR-

RFLP $\quad 132$

6.3.3.2 Taxonomische Identifikation von Pflanzen durch cpDNA-Sequenzierung.. 133

6.3.3.3 Individualidentifizierung durch STR-Genotypisierungen ............................ 135

6.3.3.4 Populationsgenetische Perspektiven....................................................... 135

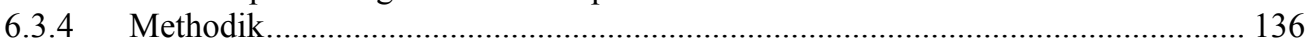

$7 \quad$ Kurzzusammenfassung.................................................................. 138

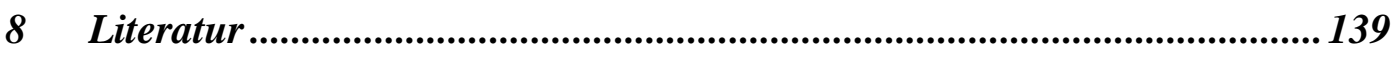

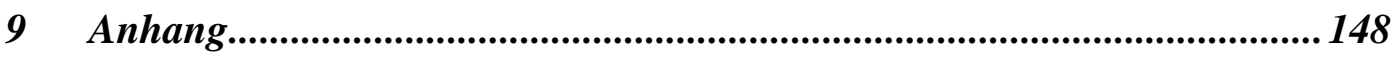

$9.1 \quad$ Einheiten und Abkürzungen ..............................................................................148

9.2 Verwendete Gräte, Chemikalien und Kits....................................................149

9.3 Eigene Publikationen ......................................................................................153 


\section{Einleitung}

Während die ersten Untersuchungen über die Isolierung alter DNA (ancient DNA; aDNA; Definition vgl. Herrmann \& Hummel 1994) noch ohne die enzymatische Amplifikation extrahierter DNA arbeiteten (Hunan medical college 1980, Higuchi et al. 1984, Pääbo 1984, Johnson et al. 1985, Doran et al. 1986), stützten sich alle folgenden Studien auf die 1985 von Saiki und seinen Mitarbeitern veröffentlichte Polymerase Kettenreaktion (PCR), der Technik, die die weitere Entwicklung des aDNA-Forschungsbereichs erst ermöglichte. Basierend auf der Überlegung, daß mitochondriale DNA verglichen mit nuklearer DNA in bis zu $10^{3}$-facher Kopienzahl vorliegt, beschränkten sich die meisten frühen aDNA-Veröffentlichungen auf die Analyse konservierter Regionen des Mitochondrions. Nachdem 1989 die Amplifikation von Fragmenten der mitochondrialen DNA (mtDNA) aus Knochen beschrieben wurde (Hagelberg et al. 1989) erschien im Jahr 1991 die erste Veröffentlichung über die Amplifikation nuklearer multicopy-DNA aus Knochen (Hummel \& Herrmann). Die erste Veröffentlichung über nukleare single copyFragmente aus prähistorischen Weichteilen war bereits 1986 erfolgt (Doran et al.). Die wesentlichen Publikationen der ersten Jahre bis 1995 befassten sich hauptsächlich mit DNA aus in Bernstein eingeschlossenen Insekten (Cano et al. 1992, DeSalle et al. 1992, inzwischen kritisch diskutiert in Austin et al. 1997, Sykes 1997), aus Knochen (Hagelberg 1989, Horai et al. 1989, Hummel \& Herrmann 1991) und aus Weichteilen von Museumstieren (Thomas et al. 1990, Cooper et al. 1992, Krajewski et al. 1992).

Die vorliegende Arbeit hat die aDNA-Analyse von Sachüberresten zum Gegenstand. Sie gliedert sich folglich in jenen Forschungsbereich ein, der die sachlichen Produkte der Menschheitsgeschichte mithilfe naturwissenschaftlicher Methoden auswertet - die Archäometrie (Herrmann 1994). Forschungsgeschichtlich beinhaltet die Archäometrie in erster Linie physikalisch-chemische Analyseverfahren, während molekulargenetische Techniken bislang kaum in Erscheinung traten (Hummel 1994). Die vorliegende Dissertation teilt mit dem Forschungsfeld der 
aDNA-Analytik die Methoden, und mit dem der Archäometrie den Untersuchungsgegenstand.

Welchen Umfang die molekulargenetischen Untersuchungen alter Sachüberreste bislang in beiden Bereichen einnehmen, kann folgende Aufzählung verdeutlichen:

Im Programm des vergangenen Archäometrie-Symposiums, das 1998 in Budapest stattfand, finden sich 290 Beiträge, davon 50 über „Biomaterialien“. Von diesen untersuchten nur drei alte DNA (Vargas-Sanders \& Salazar 2000, Burger et al. 2000c, De Reyer et al. 2000).

Von den 1995 bei der aDNA Konferenz in Oxford präsentierten Publikationen handelten acht von Pflanzen, 32 von Skeletten, sechs von Weichgeweben, zwei von Bernsteineinschlüssen, zwei von Viren, Pilzen und Bakterien und zwei beschäftigten sich mit einem archäometrischen Thema (Kahila Bar-Gal et al. 1995, Hodgins et al. 1995). Betrachtet man die Veröffentlichungslage des aDNA Kongresses in Göttingen 1997, verschob sich das Bild nur geringfügig, und zwar im Sinne eines breiteren Anwendungsspektrums. 38 Beiträge handelten von Skelettelementen, sechs von Pflanzen, fünf von Museumsstücken und Mumien, fünf von forensischen Spuren, wie getrocknetem Blut etc. Jeweils zwei Vorträge betrafen Organismen in Parafinschnitten bzw. das Thema Wildtierpopulationen und forensische Anwendungsmöglichkeiten. Über die Themen Lebensmittelanalyse, Kotreste, Bodenanalyse und DNA aus Öl wurde jeweils ein Beitrag präsentiert. Fünf Beiträge hatten ein archäometrisches Thema zum Gegenstand (Marota et al. 1997, De Reyer et al. 1997, Großkopf und Burger 1997, Hardy 1997, Kimura et al. 1997). Acht weitere Beiträge beschäftigten sich mit nicht zu klassifizierenden Themen. Kein Beitrag fand sich mehr über DNA aus Bernstein.

Von 1997 bis Ende 1999 fanden sich in Medline (http://www.ncbi.nlm.nih.gov/entrez/query.fcgi?db=PubMed) unter dem Suchbegriff „ancient $D N A^{\text {“ }} 135$ Zitate, von denen 63 von Knochen, 18 von Zähnen, 30 von mumifizierten Organismen, 15 von in Bernstein eingeschlossenen Organismen, acht von Pflanzen und einer von Koprolithen handelte. 
Aus der Aufzählung wird deutlich, daß in den ersten eineinhalb Jahrzehnten ihrer Existenz das Interesse der aDNA-Forschung in erster Linie den biologischen Organismen der Vergangenheit selbst und weniger den aus ihnen gefertigten Gegenständen galt. Die verstärkte Aufmerksamkeit, mit der zur Zeit das Thema „Kulturelles Erbe“ bedacht wird, weitet möglicherweise die Blickrichtung der Forschung auch auf Sachüberreste aus. Inwiefern die überlieferten Gegenstände unseres kulturellen Erbes sich dem molekulargenetischen Zugriff erschließen, will diese Arbeit zeigen. Zugleich wird sie deutlich machen, daß Gegenstände, Kunstprodukte und Werkstoffe nicht nur Objekte archäometrischer Fragestellungen sind, sondern ebenso Datenträger biologischer Informationen über die Organismen, aus denen sie hergestellt wurden. 


\section{Fragestellung und Zielsetzung}

Während sich aDNA-Arbeiten an Knochen seit 1989 kontinuierlich weiterentwickelten und stets Forschungsfortschritte vorweisen konnten, wurden Arbeiten an Sachüberresten vernachlässigt und blieben somit weiterhin in den physikalischchemisch-analytischen Labors angesiedelt. Eine der Aufgaben der vorliegenden Arbeit ist es, das Potential paläogenetischer Untersuchungen in der Analyse von Sachüberresten aufzuzeigen. Als Sachüberrest wird jeder Gegenstand verstanden, der als intentionelles anthropogenes Artefakt angesehen werden kann und (als basale Bedingung) eine organische Fraktion enthält. Bei Artefakten handelt es sich im Gegensatz zu primären Biomaterialien wie Skeletten oder natürlichen Sedimenteinschlüssen und Ablagerungen (z.B. Pollen) um prozessierte biologische Stoffe. Bei dem Prozessieren von Biomaterialien handelt es sich häufig um Konservierung oder Aufbereitung zur Nahrungsaufnahme. In beiden Fällen spielt die gezielte Denaturierung von Proteinen eine wesentliche Rolle. Dieses hat wiederum direkte Konsequenzen für die Präservierung bzw. Degradierung von DNA. Aber auch das Aufbereiten von Biomaterialien zu Werkstoffen beinhaltet in der Regel eine gezielte Modifizierung oder Degradierung von Biomolekülen. Insofern sind Sachüberreste im Sinne dieser Arbeit als diejenigen Gegenstände zu definieren, die vom Menschen im Rahmen seines Kulturschaffens zu einem bestimmten Zweck modifizierte Biomaterialien aufweisen.

Da diese Definition von Sachüberresten sehr weitreichend ist und Objekte unterschiedlichster Prägung und Provenienz einschließt, von der Katzen-Mumie bis zum Getreidekorn im eisenzeitlichen Tontopf, wird diese Untersuchung stellenweise nur exemplarischen Charakter haben können, aber versuchen, wesentliche Aspekte, die über den Einzelfall hinausweisen, zu beleuchten. Um nicht in den Exotismen paläontologischer und archäologischer Raritätenkabinette aufzugehen, gilt es zudem, die Fragestellungen, die (häufig von geisteswissenschaftlicher Seite) als interessant, dringend oder zukunftsweisend erachtet werden, herauszustellen. Im Folgenden werden zunächst die Arbeitsgebiete, aus denen Nachfragen nach paläogenetischen Lösungen entstehen, unterschieden. 


\subsection{Restaurierung, Konservierung und Denkmalpflege}

Im Bereich der Denkmalpflege ist es von wesentlicher Bedeutung, welcher Organismus zur Produktion eines Objekts beigetragen hat. Die grundlegenden Eigenschaften eines Materials können sich je nach Herkunftsspezies entscheidend ändern. So ist es z.B. für die Restaurierung einer Handschrift entscheidend, ob die ursprüngliche Leimung mit Leim aus Hausenblase oder dem einer anderen Fischart vorgenommen wurde. Oder: Um die Originalfarben eines alten Malers für eine Restaurierung treffend zu imitieren, ist es nötig, die verwendeten organischen Bindemittel exakt zu rekonstruieren. Darüber hinaus ist es bei der Restaurierung generelles Ziel, die Rekonstruktion bzw. Wiederherstellung erhaltenswerter Objekte möglichst authentisch durchzuführen.

\subsection{Technik- und Materialkunde}

Die Rekonstruktion alter Fertigungstechniken ist für die Technik- und Handwerksgeschichte von Interesse. Die Geschichte des Handwerks ist in Europa vom 12. bis zum 18. Jahrhundert wesentlicher Bestandteil der Sozialgeschichte. Mit der Verdrängung traditioneller Fertigungstechniken seit dem Ende des 18. Jahrhunderts durch die Massenerzeugung der Manufakturen und danach der Fabriken, sind zugleich handwerkliche Techniken und Kenntnisse verlorengegangen. Zwar werden diese durch industrielle Produktionsformen und neue Materialien ersetzt, aber aus kulturgeschichtlichem Interesse geraten alte Techniken und Materialien wieder in den Blickpunkt. Daneben spielt traditionelle Materialverarbeitung im Rahmen der sogenannten ökologischen Bewegung eine gesellschaftliche Rolle.

\subsection{Kunstgeschichte}

Die Ansprüche der Kunstgeschichte sind auf das engste verknüpft mit Fragen der Materialkunde, der Denkmalpflege, und der Restaurierung. Dennoch besteht auch ein Eigeninteresse ohne konservatorischen, praktisch-musealen Hintergrund, wenn es gilt, den künstlerischen Schaffensprozess zu beleuchten. Insofern ist die Frage, welche Bindemittel Dürer verwendete und woher sie kamen (Burmester \& Krekel 1998, Rebel 1999, Krekel \& Burmester 1998) zwar eine genuin materialkundlich- 
denkmalpflegerische, erhält aber in Verbindung mit der Künstlerbiographie eine eigene kunstgeschichtliche Bedeutung.

\subsection{Pharmazie und Medizin}

Gerade im letzten Jahrzehnt hat die Erforschung traditioneller Heilverfahren eine große finanzielle Unterstützung von Seiten der pharmazeutischen Industrie erfahren. Dies spiegelt die Einsicht wieder, daß (pflanzliche) Heilmittel der "Vorväter" pharmakologisch wirksame Stoffe enthalten können, die im ökonomischen Sinn genutzt und umgesetzt werden können. Aufgrund des Siegeszugs der modernen pharmazeutischen Industrie ist zumindest in der westlichen Welt das Tradieren konventioneller Heilmittel unterbrochen worden und das Wissen um ihre Wirkungen teilweise verlorengegangen. Möglicherweise bieten aDNA-analytische Methoden die Perspektive, einen Teil dieses Wissens zu rekonstruieren.

\subsection{Anthropologie und Archäologie}

Im Mittelpunkt anthropologischen Erkenntnisinteresses steht der Mensch als Wesen und nicht etwa als Gestalt. Insofern stellt der Mensch samt seiner Überreste nur eine von vielen anthropologischen Quellen dar. Jede weitere Quelle, die zu Antworten auf Fragestellungen über den Menschen beiträgt, ist insofern auch eine anthropologische. Folglich sind alle Produkte und Hinterlassenschaften menschlicher Tätigkeit potentielle Quellen, da sie den Menschen in seinem Verhalten und Kulturschaffen kennzeichnen. So wie der Mensch ein Teil seiner Umwelt ist, ist auch die von ihm geprägte Umwelt ein Teil des Menschen, existiert nicht ohne ihn und ist ohne ihn nicht denkbar. Jeder anthropologische Ansatz, der den nach außen verlagerten Teil des physischen Daseins des Menschen unberücksichtigt lässt, ist unvollkommen. Insofern sind Nahrungsreste in einem Grab oder Werkzeuge aus einer prähistorischen Siedlung nicht allein Objekte der Archäologie, sondern ebenso der Anthropologie. Unter diesem Gesichtspunkt ist die Zweiteilung der beiden Fächer Archäologie und Anthropologie nur eine pragmatische, aber keine inhaltlich sinnvolle. Die vorliegende Arbeit ist selbst ein Plädoyer für eine Erweiterung und Überlagerung überkommener Fächergrenzen. Das Erkenntnisinteresse bleibt 
prinzipiell ein historisch-anthropologisches, doch werden hierfür herkömmliche Fachgrenzen bereitwillig verlassen.

Das Fach Archäologie zeigt traditionell mehr Interesse an den materiellen Produkten menschlicher Aktivität als an Skeletten, Mumien und Leichenbränden. Wollte man die Definition der Archäologie als materialorientierte Altertumswissenschaft weitertragen, so ist die vorliegende Untersuchung gerade für diese Archäologie von hohem Nutzen und Stellenwert, indem sie nämlich neue Zugangswege zu archäologischen Funden aufzeigt. Organische Fraktionen archäologischer Funde können genetisch auf ihren Ursprung, auf ihre Verwandtschaft zu anderen Funden und auf ihre Funktionalität untersucht werden.

\subsection{Handschriftenkunde und Kodikologie}

Der Bereich der Handschriftenkunde bzw. Kodikologie sei aus dem weiten Feld der Kultur- und Geisteswissenschaften, die ihre Existenz der Bewahrung materieller Grundlagen verdanken, besonders herausgestellt. Zum einen weil er im Rahmen dieser Untersuchung einen Schwerpunkt darstellen wird, zum anderen weil schriftliche Erzeugnisse in der Geschichte der Kulturgüter eine herausragende Rolle einnehmen, wie folgender Exkurs verdeutlichen soll. 
Die Geschichte der Zivilisation kennt folgende Beschreibstoffe: Steine, Abris, Tontafeln, Backsteine, Rinde (z.B. Mittelamerikanisches Hieroglyphen-Manuskript auf Feigenbaumrinde, Völkerkundemuseum, Berlin s. 4.2.2.1.1, S. 20), Holz, Palmenblätter, Papyrus, Leinen, Wachstafeln, Metall, Elfenbein, Knochen und Geweih (z.B. jungpaläolithischer Lochstab aus Rentiergeweih mit Wildpferden und Ornamenten vom Petersfels), Abris (z.B. jungpaläolithische Felszeichnungen), Steine (z.B. Schieferplatten von Gönnersdorf/Neuwied, Magdalénien), Leder, Pergament und Papier. Als erste Zeugnisse einer Schrift gelten frühbabylonische Siegel aus Stein, die in Lehm gedrückt wurden. Noch in der römischen Kaiserzeit waren Steine als Beschreibstoff üblich. Verträge wurden in Stein gehauen und zur Vertragsfestigung geteilt. Diese Praxis ist bis ins 11 . Jahrhundert AD belegt. Die Ägypter führten während der IV. Dynastie Papyrus und Hautprodukte (2000-2500 v. Ch., erste belegte beschriebene Tierhaut) wohl nach assyrischem oder babylonischem Vorbild ein. Papyrus war, wie später auch bei Griechen und Römern, Hauptbeschreibstoff und herrschte mengenmäßig vor. Leder wurde wegen seiner überlegenen Qualitäten in der Handhabung und Haltbarkeit für wichtige, insbesondere sakrale Inschriften verwendet. Ktesias (405-398/7 v. Chr.), griechischer Arzt und Historiker, berichtet, daß Schaf- und Ziegenhaut von den alten Persern zur Niederschrift benutzt wurde. So sollen z.B. die Schriften von Zoroaster (9. Jh. v. Chr.) auf Rinderhaut geschrieben worden sein. Die ersten bekannten Pergamente sind die Rollen vom Toten Meer aus Qumran, die von $250-68$ v. Chr. datieren. Zeichnungen auf Grabwänden und Papyrus zeugen jedoch davon, daß Pergament bereits seit $2500 \mathrm{v}$. Chr. im Vorderen Orient und in Ägypten in Gebrauch war. Im kaiserzeitlichen Rom war Pergament in Rollenform verbreitet. Die heutige Form des Buches geht wahrscheinlich auch auf die kaiserzeitlichen Römer zurück; allerdings bestanden diese „Bücher“ nur aus zwei oder mehr zusammengehefteten Wachstafeln, die ursprünglich als „,codex“ bezeichnet wurden. Später wurden nach diesem Vorbild 
auch Pergamente zusammengeheftet. Im vierten Jahrhundert wurde Pergament dominant über Papyrus. Tatsächlich weisen Produkte aus Tierhaut mehrere Vorteile gegenüber dem pflanzlichen Papyrus auf. Leder und Pergament bieten eine hellere und flexiblere Schreiboberfläche und sind zudem leicht und gut transportierbar (Fuchs 1991). Im Gegensatz zu Papyrus sind sie beidseitig und - im Fall von Palimpsesten - sogar mehrfach beschreibbar und können zusammengebunden oder genäht werden. Außerdem sind sie länger haltbar. ${ }^{1}$

In China wurde im zweiten Jahrhundert AD das Papier erfunden. Im achten Jahrhundert wurde es von Arabern nach Spanien eingeführt. Früheste Erzeugnisse aus Papier finden sich in der okzidentalen Kultur in Griechenland (9. Jh.), in West-Europa (11. Jh.) und im Nahen Osten (13. Jh.). Bis in heutige Zeiten wird Leder als Bucheinband verwendet. Pergament als Beschreibstoff ist seit der zweiten Hälfte des 19. Jahrhunderts außer Mode gekommen und wird nur noch in seltenen Fällen gebraucht.

Die Geschichte der Beschreibstoffe, der Manuskripte, Codices, Buchrollen und Bücher ist also zugleich eine Geschichte organischer Ressourcen, im wesentlichen von Papyrus und Tierhaut. Produkte aus Tierhaut in ihren Erscheinungsformen Pergament, Leder und unbehandelte Haut begleiten die Menschheitgeschichte somit bereits seit vier Jahrtausenden. Bisher waren für die Wissenschaft nur die geschriebenen Inhalte von Bedeutung. Kodikologie, Literaturwissenschaften, Philologie und Kunstgeschichte sind nur einige der vielen Disziplinen, die sich von jeher mit Texten und Zeichen beschäftigen. Die Erforschung der materiellen Grundlagen schriftlicher und graphischer Hinterlassenschaften ist dagegen ein neues Feld (Reed \& Poole 1964, Reed 1972). Inzwischen ist Tierhaut Gegenstand zahlreicher naturwissenschaftlicher Untersuchungen, die von klassischen proteinchemischen und elektrophoretischen Aminosäurenanalysemethoden (z.B. Larsen et al. 1989) über Raman-Spektrometrie (Boghosian et al. 1999) und Elektronenresonanzspektrometrie (Rasmussen et al. 1999) bis zur Röntgen-Difraktometrie (Wess

\footnotetext{
${ }^{1}$ Angaben aus Rück 1991 und Reed 1972.
} 
et al. 1999) reichen. Die Untersuchungen haben in erster Linie neue Erkenntnisse über die Struktur von Kollagen und seine Degradierungsformen erbracht. Drei wesentliche Fragen haben die genannten naturwissenschaftlichen Methoden jedoch nicht eindeutig beantwortet: Von welcher Spezies stammt die Tierhaut, aus welchem Individuum wurde sie gefertigt und woher kommt sie? Die Nachfrage an die aDNA-Techniken besteht darin, festzustellen, ob molekulargenetische Methoden in der Lage sind, Objekte aus Tierhaut nicht nur hinsichtlich der Ähnlichkeit ihres physiko-chemischen Verhaltens zu beurteilen, sondern eindeutige Identifizierungen vorzunehmen, und zwar hinsichtlich der Spezies, des Individuums und der Population.

\section{Bisherige Arbeiten über DNA aus Sachüberresten}

Die Analyse archäologischer und kulturhistorischer Artefakte war bislang eine Domäne der Chemie, Physik und Geologie/Mineralogie. Neben Rasterelektronenmikroskopie, Spurenelementanalysen, und Diffraktometrie u.v.a. werden vor allem gaschromatographische und massenspektrometrische Methoden in der Archäometrie zur Materialanalyse und Datierung herangezogen. Gerade bei der Analyse biologischer Substanzen stoßen traditionelle physikalisch-chemische Nachweismethoden bisweilen an ihre Grenzen. Koller und Baumer (1998) haben dies exemplarisch an der Analyse von Bindemitteln ausgeführt, indem sie zeigen, daß die konventionelle Analyse gesättigter Fettsäuren zu einem verzerrten Bild der historischen Bindemittelsysteme geführt hat.

Die Veröffentlichungen zur molekulargenetischen Archäometrie sind bislang spärlich - wie in der Einleitung angedeutet - und beschränken sich darüber hinaus zum Teil auf Konferenzbeiträge.

Auf der dritten Fachkonferenz für aDNA, die 1995 in Oxford abgehalten wurde, präsentierten Kahila Bar-Gal und ihre Mitarbeiter eine Arbeit, die die Analyse 
mitochondrialer DNA aus Pergamentrollen aus der Judäischen Wüste zum Gegenstand hatte. Mittels Sequenzierung eines Abschnitts des Cytochrom B-Gens wurde Ziege als die Spezies festgestellt, aus der die Pergamente gefertigt wurden. Mit dieser Arbeit konnte gezeigt werden, daß prozessierte Biomaterialien auch nach zwei Jahrtausenden alte DNA enthalten können.

Auf derselben Konferenz stellten Hodgins und seine Mitarbeiter eine Arbeit vor, in der sie nachweisen konnten, daß alte Leime noch DNA enthalten können. In historischen Zeiten wurden Leime durch Auskochen kollagener Materialien (Knochen, Gräten, Haut, Leder- und Pergamentabfälle) hergestellt. Eine verbreitete Herstellungsweise verwendete Fischabfälle für die Leimherstellung. Hodgins und seine Mitarbeiter identifizierten aus Hausenblasenleim die Hause, eine Störspezies der kaspischen See, auf dem Speziesniveau. Da Leime und die nahe verwandten Bindemittel eine erheblich Rolle bei der Herstellung vieler Kunstwerke und Handwerksprodukte spielen, stellt diese Arbeit einen Meilenstein für die molekulargenetische Archäometrie dar. Leider wurde sie außerhalb der erwähnten Tagung und abgesehen von einer Dissertation (Hodgings 1999) bislang noch nicht veröffentlicht.

Auf der vierten aDNA Konferenz 1997 in Göttingen zeigten Marota und ihre Mitarbeiter, daß aus Papyrus entsprechende pflanzliche DNA-Sequenzen zu gewinnen sind. Die Pflanze Papyrus ist allerdings weder genetisch noch in sonstigen $\mathrm{Zu}-$ sammenhängen Gegenstand ungelöster Fragestellungen. Doch mag die Arbeit im Zusammenhang mit biochemischen Fragen der DNA-Degradierung im Rahmen von Herstellungsprozessen von Interesse sein.

De Reyer und Kollegen präsentierten die Identifizierung organischer Bestandteile in mittelalterlichen Textilien mit Goldlanen. Hardy und Kollegen zeigten daß es ihnen möglich war, von mittelpaläolithischen Steinwerkzeugen des Fundplatzes La Quina in Frankreich amplifizierbare DNA zu isolieren (Hardy et al. 1997). Bereits in den vorangegangenen Jahren waren Untersuchungen dieser Art auf scharfe Kritik gestoßen. Vor allem die Veröffentlichungen von Thomas Loy über alte Proteine und alte DNA von prähistorischen Steinwerkzeugen und Felsbildern (Loy 1983, 1990, 1993, Loy et al. 1990, Loy \& Hardy 1992, Loy \& Matthaei 1994) stießen 
auf Ablehnung und Widerstand (Downs \& Lowenstein 1990, Hyland et al. 1990, Smith \& Wilson 1990, Nelson 1991, Smith \& Wilson 1992, Fiedel 1996, Gillespie 1997) Die Kritik betraf zum ersten die Objektivität und Validität der Methode der Proteinrekristallisationsspektrometrie, da die Methode in anderen Labors nicht nachvollziehbar war. Später stellte sich heraus, daß an Stellen, von denen Proben für die Analyse von Proteinen aus Felsbildbindemitteln genommen wurden, nie Pigmente vorhanden waren. Letztendlich unglaubwürdig wurden die Arbeiten, als einer der Co-Autoren seine Beteiligung an einer Veröffentlichung zurückzog (Nelson 1991). Gillespie wies zuletzt sehr plausibel nach, daß die massenspektrometrisch festgestellten Kohlenstoffverbindungen in Felsbildern nicht aus Proteinen, sondern aus Kalziumoxalat stammen.

Die Kritik an Loys Arbeiten, die sich vor allem auf die seit 1983 veröffentlichten Proteindaten bezog, griff auch auf die folgenden aDNA-Veröffentlichungen desselben Autors über und schadete letztendlich so dem gesamten Forschungsfeld. 1996 berichtete eine unabhängige Arbeitsgruppe (Reese et al. 1996) vom erfolgreichen Nachweis boviner DNA-Sequenzen aus texanischen prähistorischen Felsbildern aus der Lower Pecos River Region.

Zusammenfassend kann festgestellt werden, daß selbst die wenigen Ansätze in der molekulargenetischen Archäometrie nicht weiterverfolgt wurden und Publikationen auf sich warten lassen. Als Ursache hierfür kann die Tatsache gelten, daß es sich bei den Arbeiten mit den kaiserzeitlichen judäischen Pergamenten, den mittelpaläolithischen Steinwerkzeugen und den paläolithischen Felsbildern durchweg um „schwieriges“ Material handelte. Dennoch besteht wie im vorigen Kapitel dargelegt, über kasuistische Untersuchungen hinausgehend Forschungsbedarf vor allem hinsichtlich der Identifizierung historischer Werkstoffe und der funktionellen Einordnung archäologischer Fundstücke. 


\section{Material und Methoden}

\subsection{Methodenüberblick}

\subsubsection{Kontaminationsprävention}

Da alte DNA in der Regel nur im Mikrospurenbereich vorliegt, erfordert die Analyse besondere Vorsichtsmaßnahmen, um Kontaminationen zu vermeiden. Man unterscheidet folgende Möglichkeiten der Kontamination bzw. deren Vermeidung (vgl. Bramanti \& Pacciani 1999):

- Eintrag rezenter DNA durch den Bearbeiter. Dieser Art von Kontamination wurde durch Tragen von Kittel, Gesichtsmaske, Einmalhandschuhen und Haarhaube entgegengewirkt.

- Eintrag rezenter DNA durch Einwegmaterialien (Schmidt et al. 1995) oder Laborgegenstände. Um die Kontaminationsgefahr zu minimieren, wurden alle Probenbehältnisse und andere Einwegmaterialien, die im Zusammenhang mit Extraktion und Amplifikation stehen, 30 min mit 254nm langem ultraviolettem Licht bestrahlt. Der Effekt der UV-Bestrahlung besteht in der Bildung von Pyrimidindimeren zwischen benachbarten Basen der oberflächlichen DNA, die folglich nicht mehr als Matrize (template) in der PCR dienen kann (z.B. Cone \& Fairfax 1993, Buoncristiani et al. 1990). Probengefäße, Lösungsbehältnisse, Meßzylinder, Glastrichter u.ä. wurden einer Reinigung in einer Extran-Lösung mit anschließender Säurebehandlung unterzogen (Schmidt 1995).

- Kreuzkontamination durch Übertragung von DNA-Spuren zwischen den Proben. Dem wurde entgegengewirkt, indem Apparaturen und Werkzeuge, die mit Probenmaterial in Berührung gekommen waren, unmittelbar danach mit Seifenlösung, aqua bidestillata und Ethanol oberflächlich gereinigt wurden. Arbeitsflächen wurden mit Seifenlösung und aqua bidestillata gereinigt. Für die Probenbehältnisse im automatischen Extraktor wurde ein Programm angewendet, das unterschiedliche u.a. auf Salpetersäure basierende Reinigungsschritte beinhaltet. 
- "carry-over"-Kontamination durch Übertragung von Amplifikationsprodukten (z.B. Cimino et al. 1990, Niehaus \& Gehrmann 1991). Um dies zu vermeiden, ist der Arbeitsbereich, der Präamplifikationsschritte enthält, räumlich von dem der Amplifikation bzw. Postamplifikation getrennt.

- Kontaminationen der Probenoberfläche. Um Oberflächenkontaminationen zu entfernen, wurden diese soweit als möglich mit einem Skalpell äußerlich abgeschabt und danach je 30 min auf zwei Seiten mit UV-Licht (254 nm) aus kurzer Entfernung (ca. $10 \mathrm{~cm}$ ) bestrahlt. Im Fall von Pergamenten und Felsbildern (s.u.) wurden diese nur abgekratzt und nicht bestrahlt, da aufgrund fehlender Oberflächen die Bestrahlung möglicherweise zu große Schäden an endogener DNA hätte führen können.

- Kontamination durch menschliche DNA. Sie stellt einen besonderen Aspekt dar und betrifft die bereits erwähnten Kontaminationen durch Bearbeiter, durch Reaktionsgefäße und darüber hinaus eventuell auch der Chemikalien während des Produktionsprozesses und die der Proben durch verschiedene Bearbeiter vor und während der Analyse. Zusätzlich zu den beschriebenen Methoden der Kontaminationsvermeidung wurde menschlichen Kontaminationen durch diskriminierendes Primerdesign entgegengewirkt (s. 6.2.1.1.1, S. 110).

\subsubsection{Voruntersuchung, Probennahme, Homogenisieren und Extraktion}

Die Vielzahl von Quellenmaterialien erfordert jeweils angepaßte Methoden der Probennahme. Bei Materialien rein organischen Ursprungs (z.B. Pergament, Leder, Knochen) wurde ein Teilstück entnommen. Bei Anhaftungen organischer Herkunft wurde die Oberfläche entweder mechanisch entfernt (z.B. mit einem Skalpell, Beispiel: Felsbilder) oder mit Hilfe eines Trägermaterials (Wattestäbchen mit Phosphatpufferlösung, Beispiel: Steinwerkzeuge) abgenommen; die Nucleinsäuren werden daraufhin aus dem Trägermaterial extrahiert. Optimal ist die Inkubation des gesamten Trägerstoffes in einer Pufferlösung zur Ablösung der Anhaf- 
tungen, da sich Reste bevorzugt in kleinen Vertiefungen erhalten (Beispiel: Steinartefakte, Felsbilder). Diese Vorgehensweise konnte allerdings nur bei sehr kleinen Artefakten, bei denen wenig Inkubationslösung benötigt wird, angewandt werden.

In den meisten Fällen gingen makro- und mikroskopische Untersuchungen des Quellenmaterials den weiteren Analysen voran, um Stellen für die Probenentnahme näher zu definieren (z.B. Gebrauchsspuren an Werkzeugen), erste Hypothesen zu generieren oder zu verwerfen und darüber hinaus Verunreinigungen und Auflagerungen zu erkennen.

\subsubsection{DNA-Extraktion}

Der besseren Übersicht wegen werden die folgenden Methoden und Vorgehensweisen der Isolation und Aufreinigung getrennt nach Materialgruppen aufgeführt. Die einzelnen Extraktionsprotokolle befinden sich in den Kapiteln zu den jeweiligen Materialgruppen (vgl. Übersicht 1).

Das Protokoll der Standard-Phenol/Chloroform-Extraktion findet sich unter „Knochen“" in Kapitel 4.2.1.2.2, das Protokoll für die Chelex- bzw. Instagen-Extraktion unter „Pergament““ in Kapitel 4.2.2.1.2, die QIAamp Tissue-Kit-Extraktion (Qiagen) und die DNeasy Plant-Kit-Extraktion (Qiagen) unter „Getrocknet Haut“ in Kapitel 4.2.2.2.2, die ATL-Lyse-Puffer/Phenol/Chloroform-Extraktion unter „Archäologische Leder und stark gegerbte Buchleder" in Kapitel 4.2.2.4.2, die CTABPhenol/Chloroform-Extraktion unter „Historische Werkstoffe“ in Kapitel 4.2.3.2.2.1, die kombinierte Chelex/Wizard-Prep-Extraktion unter „Historische Werkstoffe" in Kapitel 4.2.3.2.2.2, die Guanidinthiozyanat/Phenol/ChloroformExtraktion unter „Inhaltsreste (prä)historischer Behälter“ in Kapitel 4.2.4.2.1, das Protokoll für den Standard-Lyse-Puffer unter Steinwerkzeuge 4.2.5.2 und das Protokoll für die $\mathrm{CTAB} /$ Chloroform-Extraktion von rezenten Pflanzenproben unter „Positivkontrollen“ in Kapitel 4.2.7. 
Übersicht 1

\begin{tabular}{|c|c|c|c|}
\hline Chemikalie bzw. Extraktionsmethode & Kapitel & Kapitelnr. & Seite \\
\hline Standard-Phenol/Chloroform-Extraktion & Knochen & 4.2.1.2.2 & 18 \\
\hline Chelex- bzw. Instagen-Extraktion & Pergament & 4.2.2.1.2 & 21 \\
\hline QIAamp Tissue-Kit-Extraktion (Qiagen) & Getrocknet Haut & 4.2.2.2.2 & 23 \\
\hline DNeasy Plant-Kit-Extraktion (Qiagen) & Getrocknet Haut & 4.2.2.2.2 & 23 \\
\hline ATL-Lyse-Puffer/Phenol/Chloroform & $\begin{array}{l}\text { Archäologische Leder und } \\
\text { stark gegerbte Buchleder }\end{array}$ & 4.2.2.4.2 & 26 \\
\hline CTAB-Phenol/Chloroform-Extraktion & Historische Werkstoffe & 4.2.3.2.2.1 & 28 \\
\hline $\begin{array}{l}\text { Guanidinthiozyanat/Phenol/Chloroform- } \\
\text { Extraktion }\end{array}$ & $\begin{array}{l}\text { Inhaltsreste (prä)historischer } \\
\text { Behälter }\end{array}$ & 4.2.4.2.1 & 31 \\
\hline Standard-Lyse-Puffer & Steinwerkzeuge & 4.2.5.2 & 32 \\
\hline Chelex/Wizard-Prep-Extraktion & Historische Werkstoffe & 4.2.3.2.2.2 & 29 \\
\hline CTAB/Chloroform-Extraktion & Positivkontrollen & 4.2.7 & 33 \\
\hline
\end{tabular}




\subsection{Von der Entnahme zur Extraktion}

\subsubsection{Knochen}

\subsubsection{Material}

Bei den untersuchten Knochen handelt es sich vornehmlich um tierliches Material aus der Lichtensteinhöhle bei Osterode am Harz (Tab. 1). Der Komplex samt seiner Faunenfunde datiert in die Jüngere Bronzezeit (Unstrutgruppe, ca. 800-550 v. Chr.). Die Lichtensteinhöhle liegt zwischen der 4. Zechsteinserie und dem unteren Buntsandstein in bis zu 40m mächtigen Gipsen der 3. Zechsteinserie. Die Höhle befindet sich 2-8 m unter der heutigen Hangoberfläche (Flindt 1996). Im Inneren der Höhle wurden die an der Oberfläche befindlichen Funde durch eine mehrere Millimeter dicke Schicht Gipssinter überzogen. Die Temperatur in der Höhle liegt konstant bei $6-8{ }^{\circ} \mathrm{C}$. Die Tierfunde aus der Lichtensteinhöhle wurden nach der Bergung maximal zwei Jahre bei RT, ansonsten aber bei $-20^{\circ} \mathrm{C}$ gelagert. Die ursprüngliche Speziesbestimmung wurde nach morphologischen Kriterien vorgenommen (Bearbeiter: R. Schoon). Neun Probenindividuen wurden als Schaf bzw. Ziege bestimmt. Bei zwei Individuen konnte die Unterscheidung zwischen Schaf und Ziege nicht getroffen werden. Zwei weitere Individuen wurden als Rind bestimmt.

Tabelle 1: Knochenproben. DoT= Tierknochen aus der Lichtensteinhöhle bei Osterode/Harz. 41VV= Fund aus Texas/USA, Lower Pecos River Region

$\begin{array}{lll}\text { Probennummer } & \text { Morphologisches Taxon } & \text { Skelettelement } \\ \text { DoT 926 } & \text { Ovis aries } & \text { metacarpus } \\ \text { DoT 904 } & \text { Ovis aries } & \text { radius } \\ \text { DoT 7 } & \text { Ovis aries } & ? \\ \text { DoT 1491 } & \text { Bos taurus } & \text { metacarpus } \\ \text { DoT 1285 } & \text { Bos taurus } & \text { Wirbel } \\ \text { DoT 1584a } & \text { Capra hircus } & \text { metatarsus } \\ \text { DoT 1584b } & \text { Capra hircus } & \text { metacarpus } \\ \text { DoT 1584c } & \text { Capra hircus } & \text { femur } \\ \text { DoT 1566 } & \text { Capra hircus } & \text { ulna } \\ \text { DoT 1468 } & \text { C. hircus oder O. aries } & \text { femur } \\ \text { DoT 1477 } & \text { C. hircus oder O. aries } & \text { femur } \\ \text { 41VV-Arthi } & \text { Ruminantia } & \text { metacarpus }\end{array}$


Ein weiterer Knochenfund ist ein Sammelfund aus der texanischen Region Lower Pecos River. Gemäß den Angaben der Archäologin S. Turpin war er assoziiert mit Funden des späten amerikanischen Paläolithikums. Die Spezies konnte morphologisch nicht genauer als auf dem Niveau der Unterordnung der Ruminantia bestimmt werden.

\subsubsection{Methoden}

\subsection{Entnahme, Pulverisieren und Dekalzifizieren}

Die Proben wurden vornehmlich aus den Diaphysen von Langknochen mit Hilfe einer Rotationssäge (Typ K10 EWL, KaVa) in Form von ca. 0,5-1 $\mathrm{cm}^{3}$ großen Würfeln herausgesägt. Danach wurden die Proben in einem Stahlmörser grob zerkleinert und darauf in einer Kugelschwingmühle zu pulvriger Konsistenz gemahlen. Das Pulver wurde auf Aliquots von 0,3g in Eppendorf-Gefäße verteilt und tiefgefroren.

Die Aliquots von 0,3 g Pulver wurden in 5ml/g 0,5 M EDTA (pH 8,3) aufgenommen und die Suspension $21 \mathrm{~h}$ bei RT in einem Rotationsgerät inkubiert. Der polydentale Chelatbildner EDTA bindet die $\mathrm{Ca}^{2+}$-Ionen aus dem Hydroxylapatit des Knochens. Die Dekalzifikation der mineralischen Matrix führt zu einem Ausspülen von Zellen und organischen Zellresten aus dem suspendierten Knochenpulver. Die nicht gelösten Reste des Knochenpulvers wurden durch Zentrifugieren (4000U/min, $4 \mathrm{~min}$ ) von der Lösung getrennt und der Überstand in die Phenol/Chloroform-Extraktion überführt.

\subsection{Automatisierte Phenol/Chloroform-Extraktion}

Die Extraktionsmethode besteht im wesentlichen aus einer klassischen Phenol/Chloroform-Extraktion mit vorhergehendem Proteinase-"Verdau" und nachfolgender Fällung der Nucleinsäuren in Anwesenheit von Natriumacetat und I- 
sopropanol. Das Besondere der Methode besteht darin, daß die Fällung der Nucleinsäuren durch den Zusatz einer silikathaltigen Lösung (Glasmilch ${ }^{\mathrm{TM}}$, Dianova) unterstützt wird. Die spezifische Bindung der Nucleinsäuren an unversiegelte Glasoberflächen ermöglicht eine höhere Ausbeute und stabilere Lagerung von DNA (Hummel et al. 1995).

Die 7ml-Probenbehältnisse des automatischen DNA-Extraktors (NucleinsäureExtraktor Typ 341A, PE Biosystems) werden nach jeder zehnten Extraktion an den Innenflächen silanversiegelt, um ungewollte Bindungen an der Glasoberfläche zu vermeiden. Die programmierten Schritte der Nucleinsäurenextraktion lauten im einzelnen (nach Lassen 1993):

1. $\quad$ Beschickung der vessels mit 1,3-1,8ml Ampuwa ${ }^{\circledR}$ (Fresenius).

2. Manuelle Zugabe von 1,3ml des Überstands aus dem Dekalzifikationsschritt.

3. Zuführung von 380-650 $\mu 1$ Proteinase-K-Lösung.

4. $\quad 1 \mathrm{~h}$ Inkubation bei $60^{\circ} \mathrm{C}$ unter permanenter Durchmischung.

5. Zuführung von 2,7-3,5ml Phenol/Chloroform/Isoamylalkohol (25/24/1; $\mathrm{pH} 7,5-8,0)$.

6. 6 min Durchmischung bei RT.

7. $8 \mathrm{~min}$ Phasentrennung bei $60^{\circ} \mathrm{C}$.

8. Abzug der organischen Phase und der Interphase.

9. Zuführung von 4,0-5,3ml Chloroform (100\%).

10. 6 min Durchmischung bei RT.

11. $8 \mathrm{~min}$ Phasentrennung bei $60^{\circ} \mathrm{C}$.

12. Abzug der organischen Phase.

13. Zuführung von 64-120 $\mu 12 \mathrm{M}$ Natriumacetat $(\mathrm{pH} 4,5)$.

14. Zuführung von 2,8-3,8ml Isopropanol.

15. $75 \mathrm{sec}$ Durchmischung.

16. Manuelles Einsetzen einer Filtervorrichtung mit Teflonmembran (Präzipitette).

17. Manuelle Zugabe von $5 \mu$ l Glasmilch ${ }^{\mathrm{TM}}$ (Dianova).

18. $10 \mathrm{~min}$ Durchmischung bei RT.

19. Abzug der Flüssigkeit durch die Filtervorrichtung.

20. Zuführung von 2,8-3,8ml 80\% Ethanol.

21. 5 min Durchmischung bei RT.

22. Abzug des Ethanols durch die Filtervorrichtung.

23. Manuelle Entnahme der Filtervorrichtung mit darauf liegender DNA.

Die an die Glasmilch gebundenen Nucleinsäuren wurden mit 80\% Ethanol vom Filter gewaschen. Der Glasmilch-Nucleinsäuren-Komplex wurde abzentrifugiert (4000 U/min, $1 \mathrm{~min}$ ) und der Überstand dekantiert. Das verbliebene getrocknete Glasmilch-Nucleinsäuren-Pellet wurde in $50 \mu 1$ Ampuwa ${ }^{\circledR}$ eluiert und bei $50^{\circ} \mathrm{C}$ wurden die Nucleinsäuren in der Lösung von der Glasmilch getrennt. Die entstandene Lösung wurde bei $-20^{\circ} \mathrm{C}$ tiefgefroren; dabei wurde die Glasmilch in der Lösung belassen. 


\subsubsection{Produkte aus Tierhaut}

Produkte aus Tierhaut werden unterteilt in Pergamente, Buchleder, archäologische Leder und getrocknete, unbehandelte Tierhaut. Gemäß den spezifischen Materialeigenschaften dieser Untergruppen wurden entsprechende Extraktionsprotokolle gewählt.

\subsubsection{Pergament}

Zur Herstellung von Pergamenten sind die unterschiedlichsten Verfahrensweisen bekannt. Allen Pergamenten ist gemeinsam, daß es sich dabei um enthaarte, geglättete, ungegerbte Tierhaut handelt, die unter Spannung getrocknet wurde.

\subsection{Material}

Der größte Teil der untersuchten Pergamente entstammt einer Sammlung der Niedersächsischen Staats- und Universitätsbibliothek. Es handelt sich hierbei um neuzeitliche Fundstücke meist unbekannter Herkunft und unbekannter Fertigungsart.

Desweiteren wurde eine Probe der insularen Schrift Hs51 (Probe A4, 720-750 AD) des Skriptoriums des Klosters St. Gallen und eine weitere Probe von dem Klosterplan (A5, 850 AD) genommen. Beide Proben wurden mit einer Größe von etwa 9 $\mathrm{mm}^{2}$ der Extraktion zugeführt. Die Proben wurden von Stellen entnommen, die eine Kontamination des Materials durch andere Materialien, wie etwa Leime, unwahrscheinlich erscheinen ließen (R. Fuchs, pers. Mitteilung). Weitere Proben bestanden aus einem Pergament, von dem bekannt war, daß es ca. 10 Jahre alt war und entweder aus Hasen- oder Kaninchenhaut hergestellt worden ist. Ein anderes Pergament gleichen Alters ist angeblich aus Trampeltierhaut hergestellt worden.

Ein weiteres als PA-B bezeichnetes vermeintliches Pergament entstammt dem Museum für Völkerkunde in Berlin. Das ca. 60x90 cm große Stück stammt wahrscheinlich aus Zentralamerika und datiert vermutlich in vorspanische Zeit. Es ist mit polychromen Zeichnungen, aztekischen Hieroglyphen und einer gemalten ro- 
ten Borde versehen. Die Oberflächenstruktur lieferte keine eindeutigen Hinweise, ob es sich tatsächlich um Tierhaut handelt. Insgesamt wurden aus ca. $50 \mathrm{~mm}^{2}$ vier DNA-Extraktionen vorgenommen.

\subsection{Methoden}

3-25 mm² Pergament wurden mit einem Skalpell nach Abschürfen der Oberfläche in möglichst kleine Stücke geschnitten und dann $3 \mathrm{~h}-21 \mathrm{~h}$ entweder in Chelex ${ }^{\circledR}$ 100 Resin (Bio-Rad) oder InstaGene ${ }^{\mathrm{TM}}$ Matrix (Bio-Rad) bei $56^{\circ} \mathrm{C}$ inkubiert. Die Menge an Chelex ${ }^{\circledR} 100$ Resin bzw. InstaGene ${ }^{\mathrm{TM}}$ Matrix wurde so gewählt, daß die Probe in einem $2 \mathrm{ml}$ Eppendorf Reaktionsgefäß deutlich bedeckt war (150-600 $\mu 1)$. Danach wurde die Mischung $10 \mathrm{sec}$ in einem Vortexer geschüttelt und $8 \mathrm{~min}$ bei $97^{\circ} \mathrm{C}$ inkubiert. Nach wiederholtem zehnsekündigem Schütteln wurden die Proben mit $8.000 \mathrm{U} / \mathrm{min}$ für 3 min zentrifugiert. Von dem Überstand wurden 5 bzw. 10\% in die PCR-Reaktion überführt (vgl. Walsh et al. 1991).

Zur Methodenetablierung wurden Testreihen durchgeführt, die hinsichtlich folgender Parameter variierten: 1. Probengröße 2. Lösungsvolumen 3. Inkubationszeit (s. Tab. 7-9, S. 62)

\subsubsection{Getrocknete Haut}

Unbehandelte getrocknete Häute, wie sie in archäologischen und ethnographischen Zusammenhängen etwa als Decken vorkommen, sind gekennzeichnet durch nur oberflächlich abgeschabte Haar- und Fleischseiten. Zusätzliche chemische Prozeduren spielen keine Rolle. Die Haltbarkeit wird allein durch intensives Trocknen (in der Sonne oder an einer Heizquelle) und eventuell noch durch Salzen der Haut erreicht. 


\subsection{Material}

Im Rahmen dieser Untersuchung wurden vier Proben aus dieser Materialgruppe analysiert. Es handelt sich zum einen um eine ägyptische Tierhaut, die aus der Radverkleidung eines ägyptischen Streitwagens der frühen 18. Dynastie (ca. 1500 v. Chr.; Museo Archeologica in Florenz) stammt. Die zweite Probe (BD 578-95, Abb. 1) entstammt dem keltischen Salzbergwerk Dürrnberg, Österreich (Latène A, ca. 500 v.Chr.). Dieses Fundstück wurde mehrfach an unterschiedlichen Stellen beprobt:

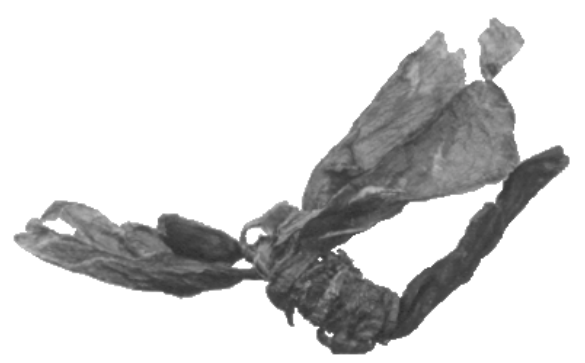

Abbildung 1: Das Fundstück BD 578-95 aus dem keltischen Salzbergwerk Dürrnberg (ca. 500 v.Chr.).

1. Die Tierhaut selbst (ursprünglich als „Wurstpelle“ angesprochen) wurde mit einem Skalpell beschnitten.

2. Die Verschnürung am unteren Ende wurde mit einem Skalpell beschnitten.

3. Die innere Oberfläche der Tierhaut wurde mit einem Skalpell abgeschürft. Dabei wurden auch kleine Bröckchen, die sich in den Faltungen in der Nähe der Verschnürung befanden aufgenommen. (Ergebnisse hierzu finden sich in Kap. 5.4 .1$, S. 74ff)

4. Die Oberfläche der Tierhaut wurde ebenso abgeschürft.

Zwei weitere Proben entstammen demselben Fundort. Bei dem Fund BD 578-K handelt es sich um ein ähnliches Stück wie bei BD 578-95, möglicherweise um einen Behälter aus Tierhaut mit pflanzlicher Verschnürung. Der Fund BD 2548 
könnte auch als Lederfund angesprochen werden. Das rechteckige Stück haftet einem Stein an und ist wahrscheinlich aufgrund seines hohen Salzgehaltes steif und hart.

\subsection{Methoden}

Das Extraktionsprotokoll für getrocknete, unbehandelte Haut ist fast identisch mit dem für Pergamente. Allein die Inkubationszeit wurde regelhaft auf $16 \mathrm{~h}$ gesetzt. Parallel wurden die Proben mit einem Extraktionskit für tierliche Gewebsproben (QiaAmp Tissue Kit, Qiagen) prozessiert. QIAamp Tissue Kit (Qiagen) ist ein kommerzielles Extraktionskit, das auf der selektiven Abtrennung von Oligonucleotiden aus Molekülgemischen mittels einer Silikamembran und anschließender Reinigung der immobilisierten DNA auf der Membran beruht.

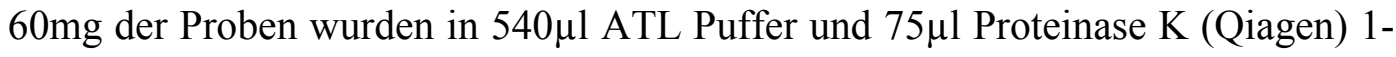
$3 \mathrm{~h}$ bei $55^{\circ} \mathrm{C}$ inkubiert. Danach wurden $600 \mu \mathrm{l}$ AL Puffer hinzugefügt und die Lösung bei $70^{\circ} \mathrm{C} 10$ min inkubiert. Nach Zugabe von $630 \mu 199 \%$ EtOH wurde die Lösung auf die membrantragende Säule gegeben und 1min bei 8000 U/min zentrifugiert. Es folgte das zweimalige Waschen mit jeweils 500 $\mu 1 \mathrm{AW}$ Puffer. Die Elu-

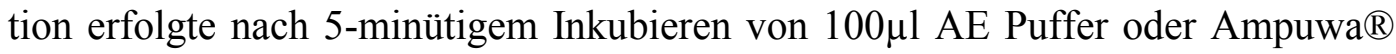
auf der Membran durch Zentrifugation bei 8000 U/min. Der letzte Schritt wurde einmal wiederholt.

Die DNA Extraktion aus der Verschnürung des Dürrnberger Fundes wurde mit einem Pflanzenextraktionskit (DNeasy Plant Kit, Qiagen) vorgenommen. Bei der Extraktion mit dem DNeasy Plant Kit wurde nach folgendem Protokoll verfahren: Mit einem Skalpell in kleine Stücke geschnittenes Material wird in der Menge an Inkubationspuffer (AP1), die ausreicht, um das Probenmaterial in einem $2 \mathrm{ml}$ Reaktionsgefäß zu überdecken, inkubiert. Nach $3 \mathrm{~h}$ Inkubation bei $65^{\circ} \mathrm{C}$ und zwischenzeitlichem Schütteln wurde $390 \mu 1$ Puffer AP2 hinzugegeben und weitere 10 min inkubiert. Grobe Reste des Lysats wurden über einen physikalischen Filter (QIAshredder) abgetrennt und das Zentrifugat (ohne Pellet) zu 0,5 Vol. Puffer AP3 und 1 Vol. Ethanol (99\%) gegeben. Die Lösung wurde durch einen Silikatfil- 
ter, der Oligonucleotide selektiv bindet, zentrifugiert. Die auf dem Filter sitzende DNA wurde mit dem Puffer AW gewaschen (dreimal) und mit $\mathrm{H}_{2} \mathrm{O}$ vom Filter eluiert.

\subsubsection{3 (Buch-) Leder}

Die Fertigung von Leder aus Tierhaut unterscheidet sich von der von Pergament wie in Kapitel 6.1.2.3 (S. 95ff) dargestellt. Besonders für Leder können die Fertigungsmethoden sehr unterschiedlich sein. Allen Verfahren gemeinsam ist die Prozedur des Gerbens mit Hilfe von Gerbsäuren (s. Kap. 6.1.2.3, S. 95).

\subsection{Material}

Als Proben wurden verschiedene neuzeitliche Bucheinbände aus der Niedersächsischen Staats- und Universitätsbibliothek, Göttingen, verwendet (z.B. Abb. 2).

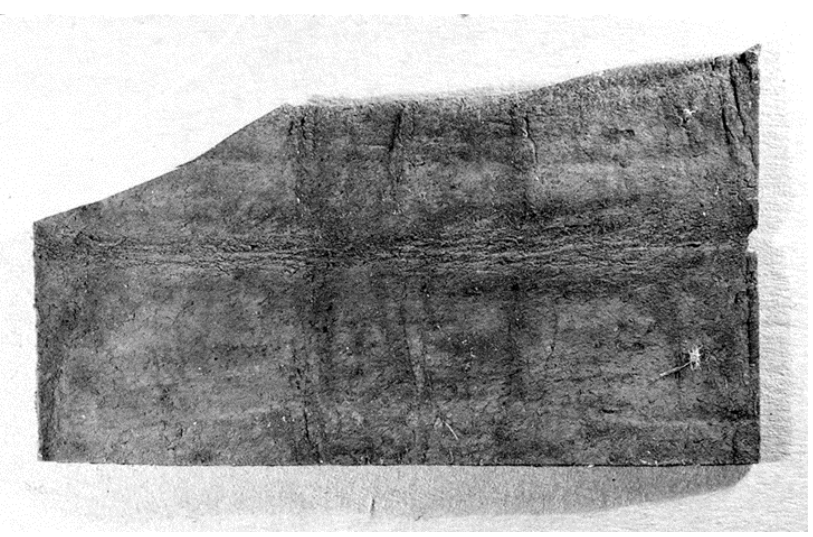

Abbildung 2: Buchleder, ca. 70 BP 


\subsection{Methoden}

Buchleder wurde mit einem Skalpell in 4-15 $\mathrm{mm}^{2}$ Probenstücke geschnitten und danach mit dem Skalpell in möglichst kleine Fragmente zerteilt. Diese wurden 1520h in ATL Lysis Puffer (Qiagen $\left.{ }^{\circledR}\right)$ und Proteinase K (Qiagen ${ }^{\circledR}$ ) inkubiert. Die Menge an Lysis Puffer und Proteinase K wurde so gewählt, daß sie die Probe deutlich überdeckte (200-600 $\mu$ l Lysepuffer, 75-225 $\mu$ l Proteinase K). Danach wurden die verbleibenden festen Bestandteile des Leders mit Hilfe eine Säulenfilters (QIAshredder, Qiagen ${ }^{\circledR}$ ) von der flüssigen Lösung getrennt. Die Lösung wurde gemäß den Angaben des Herstellers einer Extraktion unterzogen, die auf dem selektiven Abtrennen von Oligonucleotiden von anderen Substanzen mit Hilfe eines Silikafilters und auf anschließenden Reinigungsschritten der auf dem Filter immo-

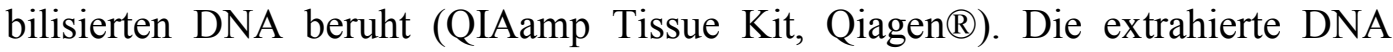
wurde mit $100 \mu 1$ Elutionspuffer von der Membran eluiert. Das erste Eluat wurde für eine zweite Elution wiederverwendet (vgl. 4.2.2.2.2, S. 23).

Buchleder, welches durch stark dunkle Färbung oder PCR-Inhibition des Extrakts auffiel, wurde behandelt wie archäologische Leder (s.u.).

\subsubsection{Archäologische Leder und stark gegerbte Buchleder}

Archäologisches Leder ist aufgrund der langen Liegezeit im Boden dadurch gekennzeichnet, daß es während der Diagenese organische Geopolymere aufgenommen hat (Burger et al. 2000d). Als stark gegerbtes Buchleder wurde das angesehen, welches durch eine dunkelbraune Färbung auffiel. Archäologisches Leder hat die starke Kontamination mit Polymeren phenolischer Natur mit stark gegerbtem Buchleder gemeinsam, weswegen beide dem gleichen Extraktionsprotokoll unterzogen wurden. 


\subsection{Material}

Ein Lederfund der Jüngeren Bronzezeit (800-550 v.Chr.) aus der Lichtensteinhöhle bei Osterode/Harz (Flindt 1996) wurde beprobt. Desweiteren wurden drei stark gefärbte Buchleder aus der Sammlung der Staats- und Universitätsbibliothek Göttingen untersucht.

Daneben wurden Lederproben aus dem frühkeltischen Fürstengrabhügel am Glauberg (Wetteraukreis, Latène A, 5. Jh. v. Chr.) untersucht. Die Begräbnisstätte eines reich mit Goldschmuck und eisernen und bronzenen Waffen ausgestatteten männlichen Individuums enthielt mehrere Fundstücke, die trotz schlechten Erhaltungszustandes als Leder bezeichnet werden können. Man kann eine weitere Unterteilung der Funde vornehmen in Stücke, die eindeutige morphologische Strukturen erkennen lassen („Leder") und solche, die nur mit hoher Wahrscheinlichkeit aber nicht mehr mit Sicherheit als Leder identifiziert werden können (,vergangenes Leder"). Insgesamt wurden 12 Proben untersucht:

- Leder: Wi237, Wi267

- Vergangenes Leder: Wi49, Wi50a, Wi50b, Wi50d, Wi76/1, Wi76/3, Wi76/6, Wi76/8, Wi76/9, Wi91,

\subsection{Methoden}

Archäologische Lederfunde und Buchleder mit hohem Gerbstoffanteil wurden folgendem Protokoll unterzogen:

Proben wurden mit einem Skalpell in 4-15 $\mathrm{mm}^{2}$ Stücke geschnitten und danach mit dem Skalpell in möglichst kleine Fragmente zerteilt. Diese wurden 16h in ATL Lysis Puffer (Qiagen $\left.{ }^{\circledR}\right)$ und Proteinase K (Qiagen $\left.®\right)$ inkubiert. Die Menge an Lysis Puffer und Proteinase K wurde so gewählt, daß sie die Probe deutlich überdeckte (200-600 $\mu$ l Lysepuffer, 75-225 $\mu$ l Proteinase K). Danach erfolgte eine zweiminütige Zentrifugation mit $4.000 \mathrm{U} / \mathrm{min}$. Der Überstand wurde in ein automatisches DNA Extraktionsgerät (Genepure 341 A, PE Biosystems) überführt. Dort wurde die Probe einer Phenol/Chloroform-Extraktion mit Präzipitation in 
Anwesenheit von Glasmilch (Glasmilk ${ }^{\mathrm{TM}}$, Geneclean ${ }^{\circledR}$ Bio101), 2-Propanol und Natriumacetat unterzogen (genaues Protokoll s. 4.2.1.2.2, S. 18f). Die Elution erfolgte mit $50 \mu 1 \mathrm{H}_{2} \mathrm{O}$ (Ampuwa ${ }^{\circledR}$, Fresenius).

\subsubsection{Leime, Bindemittel und Öle}

\subsubsection{Prähistorische Felsbilder}

\subsection{Material}

Proben von Felsbildpigmenten wurden an einem Abris (41VV75) der Lower Pecos River Region, Texas, USA genommen. Dabei wurden 2 bis $50 \mathrm{~cm}^{2}$ große Platten unterschiedlicher Pigmentfarben (rot, schwarz, braun, ocker) aus dem Kalkstein gelöst. Zusätzlich wurden Kontrollproben von nicht pigmentierten Stellen genommen. Die Probenentnahme wurde an Stellen vollzogen, an denen mit möglichst geringer Sonneneinstrahlung im Jahresverlauf $\mathrm{zu}$ rechnen war und die so hoch lagen, daß größeren Tieren der Kontakt mit dem Felsbild unmöglich war.

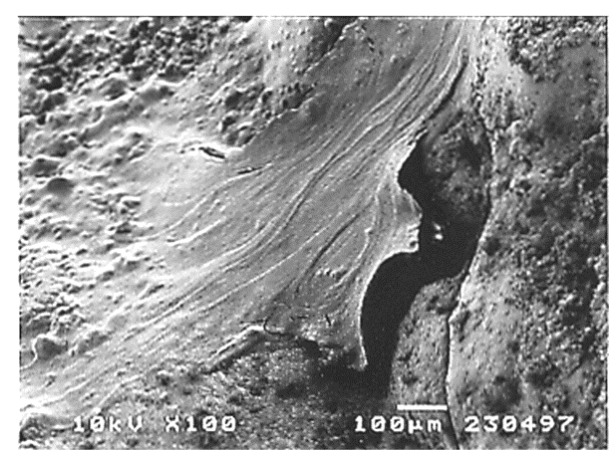

Abbildung 3: Rasterelektronenmikroskopische Aufnahme (Jeol JSM-5400, ca. x70) der Oberfläche eines texanischen Felsbilds. Dargestellt ist der Übergang von pigmentierten Stellen (Mitte) zu reinem Kalkstein. 


\subsection{Methoden}

Die Oberfläche der pigmentierten und nichtpigmentierten Kalksteine wurde rasterelektronenmikroskopisch untersucht (Jeol JSM-5400, Abb. 3). Danach wurde die Oberfläche sorgfältig bis auf die Pigmentschicht abgekratzt und der Abrieb verworfen. Darauf wurde die Pigmentschicht selbst abgekratzt und der Abrieb (0,2g) in die Extraktion überführt. Die Felsbildproben wurden mit folgenden Extraktionsmethoden untersucht: Lyse-Puffer/Phenol/Chloroform-Extraktion (Kap. 4.2.5.2, S. 32 u. 4.2.1.2.2, S. 18f), CTAB-Puffer-Phenol/Chloroform-Extraktion (4.2.2.3.2, S. 25f) QIAamp Tissue-Kit (4.2.2.2.2, S. 23) und Chelex-Extraktion (4.2.2.1.2, S. 21).

\subsubsection{Historische Werkstoffe}

\subsection{Material}

Zur Methodenetablierung wurden eine etwa 5-10-jährige Probe von Hausenblasenleim und eine Probe von der rohen Hausenblase verwendet. Von Letzterer wurden ca. $9 \mathrm{~mm}^{2}$ sowohl ungelöst als auch ,ausgekocht“ $\left(1 \mathrm{~h}, 80^{\circ} \mathrm{C}\right)$ in die Reaktionen eingesetzt. Desweiteren wurden moderner Hasen- und Körnerhautleim, modernes Kasein und Walnußöl beprobt.

\subsection{Methoden}

DNA wurde aus Leimen, Bindemitteln und Ölen mit drei unterschiedlichen Methoden gewonnen, wobei die kombinierte Chelex ${ }^{\circledR} 100$ Resin (Bio-Rad)/Wizard PCR Prep ${ }^{\mathrm{TM}}$ - Methode in direktem Vergleich mit der Qiagen-Methode getestet wurde.

\subsection{CTAB-Puffer und Phenol/Chloroform Extraktion} O,5 g bzw. 0,5ml Probe wurden bei $60^{\circ} \mathrm{C}$ in 1,5ml CTAB-Puffer $18 \mathrm{~h}$ inkubiert.

CTAB-Puffer: $\quad 2 \%$ CTAB (Hexadecyltrimethylammoniumbromid) 0,2\% Mercaptoethanol 


\section{$1,4 \mathrm{M} \mathrm{NaCl}$ \\ 20mM EDTA \\ $100 \mathrm{mM}$ Tris}

Nach kurzem Anzentrifugieren wurde der flüssige Überstand in eine automatische Phenol/Chlorophorm-Extraktion überführt, wie sie unter 4.2.1.2.2 (S. 18f) dargestellt ist.

\subsection{Chelex ${ }^{\circledR} 100$ Resin / Wizard PCR Prep ${ }^{\mathrm{TM}}$ - Extraktion}

$0,15 \mathrm{~g}$ der Proben wurden in $350 \mu 1$ PBS Puffer, $10 \mu 1$ Proteinase K und $200 \mu 1$ 0,5 M EDTA bei $56^{\circ} \mathrm{C}$ aufgenommen bzw. gelöst. Nach Zugabe von $250 \mu 15 \%$ Chelex ${ }^{\circledR}$ 100 Resin (Bio-Rad) Lösung inkubierten die Proben $45 \mathrm{~min}$ bei $56{ }^{\circ} \mathrm{C}$. Nach 10 sec Abzentrifugieren wurden die Lösungen 8 min auf $95{ }^{\circ} \mathrm{C}$ erhitzt und danach 10 sec gevortext. Die Lösungen wurden danach $3 \mathrm{~min}$ bei $8000 \mathrm{U} / \mathrm{min}$ zentrifugiert. $350 \mu 1$ des Überstands wurden mit $100 \mu 1$ Direct Purification Buffer gemischt. Danach wurde $1 \mathrm{ml}$ Magic PCR Prep Resin hinzugegeben und die Lösung innerhalb einer Minute drei Mal kurz gevortext. Die Lösung wurde daraufhin mithilfe einer Spritze durch eine minicolum gedrückt. Nach dem Waschen mit 80 \% Isopropanol und anschließendem $20 \mathrm{sec}$ Zentrifugieren bei $10.000 \mathrm{U} / \mathrm{min}$ wurde nach zehn Minuten die DNA nach Zugabe von 50 $\mu$ l Ampuwa ${ }^{\circledR}$ (Fresenius) durch $20 \mathrm{sec}$ $10000 \mathrm{U} / \mathrm{min}$ Zentrifugation eluiert.

\subsection{QiaAmp Tissue Kit-Extraktion}

Die QiaAmp Tissue Kit-Extraktion wurde mit jeweils 0,15g Probenmaterial wie in 4.2.2.2.2 (S. 23) dargestellt durchgeführt. 


\subsubsection{Inhaltsreste (prä)historischer Behälter}

\subsubsection{Material}

\subsection{Mittel- und südamerikanische Behälter des Museums für Völkerkunde in Berlin}

Die Proben wurden im Berliner Museum für Völkerkunde aus süd- und zentralamerikanischen Gefäßen entnommen. Die Gefäße stammen aus vorspanischer Zeit und befinden sich in ungewaschenem Zustand. Die Beschreibungen der Behälter und Proben finden sich in Tabelle 2.

\section{Tabelle 2:}

VA 40054

VA 40178

VA 16822

VA 39997

VA 7040

VA 31110a

VA 65266

VA 28404

VA 8913

VA 36594

VA 36593

VA 45220

VA 40336

IVCa 1855

IVCa 9227

IVC21119a

IVCA 19050

IVCA $1905 \mathrm{c}$

IVCA 25480

IVCA 28048
Ovales Gefäß mit verbackener "Weihrauch"-Mischung

Kleiner Topf aus Holz, randvoll mit brauner korkartiger Masse

Sehr kleines Töpfchen, geschlossen, mit "Kokons"

Holzteller mit korkartiger Innenverkleidung

8-förmiges Gefäß mit kakaofarbigem Innenüberzug

Gefäß mit Holzfigur und Perlmutteinlagen. Unter diesen Leim (?)

Verbackenes geologisches Material, evtl. Ocker oder Eisenoxid (Pigmente?)

Hoher Holztopf mit gekittetem Riss u. Leder (?)-Resten

Großer Holztrog mit Floraresten in den Ritzen

Kleiner Topf mit "Weihrauch"

Kleiner Topf mit duftigem Inhalt.

"Würfelbecher" aus Holz mit braunem, hartem Inhalt.

Holzmörser mit Federn

Dreifüßiger polychromer Kelch mit rötlichem und grauen Inhalt (Abbildung 4)

Kopfgefäß mit 2 Löchern am Rücken

Wie IVCa 9227, 1 Loch

Mittelgroßer Tontopf, randvoll mit schwarzer, kotiger Masse, harzig u. haarig

Ausgebrochene Tonschale mit dünner Schicht schwarzer Masse

Wie IVCA 19050, aber Masse härter und kristalliner

Tongefäß mit Maske. Auf dem Boden schwarze, verklebte Masse, glänzend, Glasaugen aus Muschel mit Erdballen als Pupille

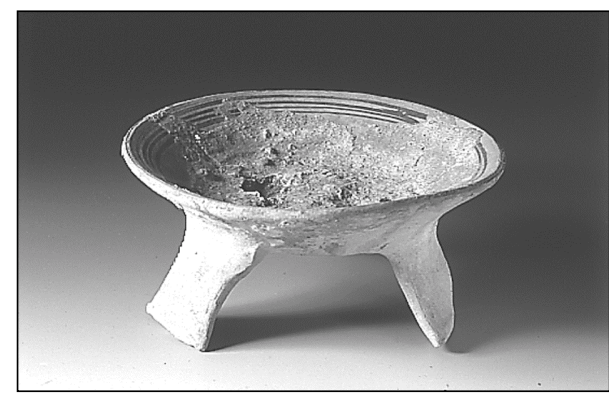

Abbildung 4: Dreifüßiger polychromer Kelch mit rötlichem und grauen Inhalt (IVCa 1855) 


\subsection{Nachgeburtsbestattungen}

Die vermeintlichen Nachgeburtstöpfe der frühen Neuzeit wurden aus Kellerböden südwestdeutscher Gemeinden (Stadt Bönigheim) geborgen. Die Proben wurden aus den mit Erde verfüllten Gefäßen entnommen, indem die Bereiche an der Gefäßwand großzügig abgetragen wurden. Offensichtlich bestanden die Proben in erster Linie aus Erdreich.

\subsubsection{Methoden}

Nachdem die Oberfläche der Probenentnahmestelle abgekratzt worden war, wurden die Proben mit Spateln ausgekratzt. Bei den Proben VA 47280, VA 8913, VA 40336 IVCA, 28048 und den Nachgeburtsbestattungen konnten keine entsprechenden Oberflächendekontaminationen vorgenommen werden.

\subsection{Guanidinthiocyanat-Phenol/Chlorophorm-Methode}

0,5g der Probe wurde mit 1,5ml Extraktionspuffer $18 \mathrm{~h}$ bei $56{ }^{\circ} \mathrm{C}$ inkubiert

Extraktionspuffer (pH7): $\quad 4 \mathrm{M}$ Guanidinthiocyanat

$0,5 \%$ Nonidet $\mathrm{P} 40$

$25 \mathrm{mM}$ EDTA

$100 \mathrm{mM} \mathrm{NaCl}$

100mM Mercaptoethanol

Nach kurzem Abzentrifugieren wurde der Überstand der Lösung in eine automatische Phenol/Chloroform-Extraktion überführt, wie sie unter 4.2.1.2.2 (S. 18f) beschrieben ist.

\subsection{QIAamp Tissue Kit - MagicPrep-Extraktion}

$75 \mathrm{mg}$ Probe wurde $18 \mathrm{~h}$ bei $56^{\circ} \mathrm{C}$ mit $540 \mu \mathrm{l}$ ATL Puffer (Qiagen) und $75 \mu 1$ Proteinase K (Qiagen) inkubiert und danach entsprechend dem Protokoll, wie es in 4.2.2.2.2 (S. 23) dargestellt ist weiter behandelt. Die Aufreinigung des Extrakts erfolgte nach dem MagicPrep Purification System Extraktionsprotokoll, wie es in 
4.2.3.2.2.2 (S. 28) beschrieben wurde. Die Elution erfolgte mit 50 $\mu 1$ Ampuwa ${ }^{\circledR}$ (Fresenius). Mit dem ersten Eluat wurde eine zweite Elution vorgenommen.

\subsubsection{Steinwerkzeuge}

\subsubsection{Material}

Rezente Silexknollen wurden vom Bearbeiter zu scharfen Klingen geschlagen und mit humanen Blutabstrichen versehen. Die Klingen wurden nach einwöchigem Trocknen analysiert. Eine Klinge wurde vor der Analyse eine Woche in einem humösen Gartenboden nahe der Oberfläche im Freien vergraben.

\subsubsection{Methoden}

Von den Klingen und dem Faustkeil wurden Reste des Blutabstrichs mithilfe eines mit Phosphatpuffer (PBS-Puffer) getränkten synthetischen „Wattestäbchens“ abgenommen. Die DNA Extraktion erfolgte danach aus den synthetischen Fasern des Stäbchens. Kleinere Abschläge $(<2 \mathrm{~cm})$ wurden vollständig in Lysepuffer gelegt. Lysepuffer: $\quad$ 10mM Tris

$1 \mathrm{mM}$ EDTA

$0,001 \%$ SDS

$100 \mu 1$ Proteinase K

Der Lysepuffer bzw. der „Watte“-Teil des Stäbchens wurden in ATL-Puffer (Qiagen) überführt und daraufhin gemäß dem in 4.2.2.2.2 (S. 23) dargestellten Protokoll prozessiert. Eine Probe wurde mit dem Extraktionskit von Boehringer gemäß den Angaben des Herstellers prozessiert. 


\subsubsection{Archäologische Textil- und Pflanzenfunde}

Hierunter werden Funde verstanden, die nicht eindeutig morphologisch identifiziert oder einem bestimmten Zusammenhang zugeordnet werden können. Es wurden Textil- und Bastfunde vom keltischen Fundplatz „Am Glauberg“ (Wetteraukreis, Latène A) untersucht, die alle kürzer als $0,5 \mathrm{~cm}$ waren und zudem nur mit einer gewissen Unsicherheit als Textil oder Bast angesprochen werden konnten.

Tabelle 3: Proben vom keltischen Fundplatz Glauburg und ihre morphologische Einordnung

\begin{tabular}{|c|c|}
\hline Fd.-Nr. & Art \\
\hline Wi127 & Bast \\
\hline Wi128 & Bast \\
\hline Wi132 & Bast \\
\hline Wi129 & Textil? \\
\hline Wi130 & Textil? \\
\hline Wi133 & Textil? \\
\hline Wi134 & Textil? \\
\hline
\end{tabular}

\subsubsection{Positivkontrollen}

Tierliche und menschliche Positivkontrollen aus Tierfleisch bzw. humanem Sputum oder peripherem Blut wurden nach dem QIAamp Tissue Kit (Qiagen)Extraktionsprotokoll prozessiert.

Zur Methodenetablierung des PCR-RFLP (s.u.) wurde eine forensische Probe herangezogen. Dabei handelte es sich um mit Blut behaftete Baumblätter, die bei einer Jagdhundprüfung als Schleifspur gelegt wurden. Drei unabhängige Extrakte wurden mit der QIAamp Tissue Kit Methode erstellt (IP1.1, 2, 3). Ergebnisse hierzu finden sich in Kapitel 5.1.2 („Knochen“, S. 58ff), in dem sich alle Ergebnisse des PCR-RFLP wiederfinden.

Pflanzliche Kontrollproben wurden nach folgendem Protokoll hergestellt: 
0,5g gemörserte oder geschnittene Probe wurde in 5ml CTAB-Puffer gegeben und bei $60^{\circ} \mathrm{C} 30 \mathrm{~min}$ geschüttelt. Danach wurden $5 \mathrm{ml}$ Chloroform/Isoamylalkohol zugegeben, die Lösung gemischt und bei $13.000 \mathrm{U} / \mathrm{min} 10 \mathrm{~min}$ zentrifugiert. Der Überstand wurde mit $10 \mathrm{ml}$ kaltem Isopropanol versetzt und nach Mischen bei $8000 \mathrm{U} / \mathrm{min} 2 \mathrm{~min}$ zentrifugiert. Das Pellet wurde in 10ml Waschpuffer (76\% EtOH, 10mM Ammoniumacetat) aufgeschüttelt und nach $20 \mathrm{~min}$ bei $8000 \mathrm{U} / \mathrm{min}$ zentrifugiert. Nach Abnahme des Überstands wurde das Pellet luftgetrocknet und in $1 \mathrm{ml}$ TE-Puffer bzw. 500 $\mu 1$ Ampuwa ${ }^{\circledR}$ aufgenommen.

\subsubsection{Extraktionskontrollen}

- Phenol/Chloroform-Extraktion: 1. Anstelle des Überstands aus der Zentrifugation des dekalzifizierten Knochens wurde reines EDTA eingesetzt. 2. Für Lederproben mit hohem Anteil an Gerbstoffen bzw. Huminsäuren und für archäologisches Leder wurden $360 \mu$ ATL-Puffer (Qiagen) in die Extraktion eingeführt. 3. Bei Leimen, Bindemitteln und Ölen wurden 1,5ml CTAB-Puffer eingesetzt. 4. Bei den mittel- und südamerikanischen Proben aus Berlin wurde 1,5ml Extraktionspuffer eingesetzt.

- Chelex ${ }^{\circledR} 100$ Resin (Bio-Rad) bzw. InstaGene ${ }^{\mathrm{TM}}$-Etraktion: Der Überstand einer nicht mit Probe versehenen Chelex ${ }^{\circledR} 100$ Resin (Bio-Rad)/ InstaGene ${ }^{\mathrm{TM}}$ Negativextraktion wurde verwendet. Im Falle einer folgenden Aufreinigung wurde der Überstand im MagicPrep Purification System mitgeführt.

- QIAamp Tissue Kit (Qiagen): Es wurde eine Negativextraktion ausgehend von $360 \mu 1$ ATL-Puffer durchgeführt. 


\subsection{PCR}

Alle Amplifikationen wurden in den Thermocyclern „DNA Thermal Cycler 480“ von Perkin Elmer durchgeführt. Im Folgenden werden die Protokolle getrennt nach Organellen-DNA (mtDNA und cpDNA) und nuklearer DNA aufgeführt.

\subsubsection{Organellen-DNA}

\subsubsection{Primerdesign}

Um universelle bzw. semiuniverselle Primer zur taxonomischen Identifizierung tierlicher und pflanzlicher organischer Spuren herzustellen, wurde folgende Vorgehensweise angewandt: Mit Hilfe des vom National Center for Biotechnology Information (NCBI; http://www.ncbi.nlm.nih.gov/) bereitgestellten Programms Taxonomy Browser wurden die mitochondrialen Sequenzen der jeweiligen loci von unterschiedlichen Spezies in GenBank lokalisiert. Die Auswahl der Spezies erfolgte bei Tieren in erster Linie unter dem Kriterium, ob die Tiere in historischen Zeiten als Nutztiere oder Haustiere verwendet werden konnten. Außerdem wurde darauf geachtet, von unterschiedlichen Familien aus unterschiedlichen Ökotopen und Kontinenten jeweils repräsentative Vertreter zu finden. Soweit möglich, wurden für jede Spezies zwei Individuen verwendet. Pflanzenreferenzen wurden allein nach dem Kriterium unterschiedlicher kontinentaler Herkunft ausgewählt. Anfänglich wurden die Sequenzen im Programm Seq-App per Hand nach homologen Positionen geordnet (sogenanntes Sequenz-alignment). Später erfolgte dies mit Hilfe des Programms MegAlign aus dem Softwarepaket von DNASTAR, Inc. Die Strategie beim Erstellen von Primern bestand aus folgenden Einzelkriterien²

- Primer sollen etwa 18-24bp lang sein

\footnotetext{
${ }^{2}$ In Kapitel 6.2.1.2 werden diese Strategien im Spiegel der während der Arbeit gewonnenen Erkenntnisse teilweise neu formuliert.
} 
- Die von den Primern eingeschlossene Sequenz soll inklusive der Primer nicht länger als 400bp, in den meisten Fällen kleiner als 200bp sein.

- Primer sollen sich an Stellen befinden, die zwischen Spezies (Genera) eine geringe Variabilität zeigen.

- Zwischen den beiden Primern sollen sich Sequenzen hoher Variabilität hinsichtlich der Spezies (Genera) befinden.

- Die loci sollen keine Variabilität zwischen Individuen gleicher Spezies aufweisen.

- Am 3'-Ende sollen, wenn möglich, beide Primer Nichtbindungsstellen (mismatches) von 1-3bp mit Homo sapiens aufweisen.

Letzteres gilt nur für mitochondriale DNA, da beim Nachweis von Pflanzen-DNA kontaminierende Hintergrund-DNA von Menschen kaum eine Rolle spielt. Ein weiterer Unterschied zwischen Pflanzen- und Tier-Primern ist der Umstand, daß nur wenige Pflanzen mit Hilfe des rbcL-locus auf dem Speziesniveau diskriminiert werden können (Soltis et al. 1990). Wenn die Diskriminierung auf dem Speziesniveau nicht möglich ist, gelten die genannten Kriterien für die nächst höheren taxonomischen Einheiten (Genus, Familie, etc.).

Im Folgenden werden die loci kurz beschrieben und die entsprechenden Primer mit ihren Protokollen aufgeführt.

\subsubsection{Mitochondriale DNA (mtDNA)}

\subsection{S ribosomale RNA codierender locus}

Dieses Gen codiert die kleine Untereinheit ribosomaler RNA des Mitochondrions und befindet sich auf dem Mitochondrion auf Position 648-1601.

Primersystem rR4

Primer a: 5'AAC TGG GAT TAG ATA CCC CAC TA 3' (Position 1068-1098)

Primer b: 5'CGA TTA TAG GAC AGG CTC CTC T 3' (1196-1217)

Primer c: 5'GAA GCA CCG CCA AGT CCT 3' (1168-1185) 
rR4ac: 118 Basenpaare, rR4ab: 150 Basenpaare

Amplifikationsbedingungen: $94^{\circ} \mathrm{C} 1 \mathrm{~min} ., 56^{\circ} \mathrm{C} 1 \mathrm{~min} ., 72^{\circ} \mathrm{C} 1 \mathrm{~min}$.

$60 \mathrm{mM} \mathrm{KCl} ; 12 \mathrm{mM}$ Tris-HCl; $2.5 \mathrm{mM} \mathrm{MgCl} 2 ; 150 \mu \mathrm{M}$ dNTPs; $0.18 \mu \mathrm{M}$ jeder Primer; 2U AmpliTaq Gold ${ }^{\mathrm{TM}}$ (PE Biosystems).

Eigenschaften: Das Primersystem amplifiziert Mammalia und einige nicht näher definierte Spezies anderer Klassen.

\subsection{Cytochrom b}

Das Gen codiert ein Protein, welches in der Elektronentransportkette eine Rolle spielt. Ausnahmsweise handelt es sich bei diesem mitochondrialen Gen nicht wie bei anderen Proteinen des Mitochondrions um eine Untereinheit eines größeren Enzymkomplexes, sondern um ein voll funktionsfähiges Monomer. Es befindet sich auf Position 14747-15887 (vgl. Irwin et al. 1991).

Primersystem cyB:

Primer a: 5'- GAA TCT GCC TAA TCC TAC AAA TCC -3'

Primer b: 5'- CTC CGT TTG CGT GTA TGT ATC G -3'

Position: 113 bis 259

Länge: 147 Basenpaare

Amplifikationsbedingungen: $94^{\circ} \mathrm{C} 1 \mathrm{~min}, 51^{\circ} \mathrm{C} 1 \mathrm{~min}, 72^{\circ} \mathrm{C} 1 \mathrm{~min}$

$60 \mathrm{mM} \mathrm{KCl} ; 12 \mathrm{mM}$ Tris- $\mathrm{HCl} ; 2,5 \mathrm{mM} \mathrm{MgCl}_{2} ; 200 \mu \mathrm{M}$ dNTPs; $0,2 \mu \mathrm{M}$ Primer; $2 \mathrm{U}$ AmpliTaq Gold ${ }^{\mathrm{TM}}$.

Eigenschaften: Der Primer amplifiziert Mammalia, v.a. die gängigen Haustierspezies.

Primersystem CB 1:

Primer a: 5'- GAT GGA ATT TCG GTT CCC TCC T-3' 
Primer b: 5'-CGT ATC CTA TGA ATG CTG TGG C-3'

Position: 89-394

Länge: 306 bp

Amplifikationsbedingungen: $94^{\circ} \mathrm{C} 1 \mathrm{~min}, 52^{\circ} \mathrm{C} 1 \mathrm{~min}, 72^{\circ} \mathrm{C} 1 \mathrm{~min}$

$60 \mathrm{mM} \mathrm{KCl} ; 12 \mathrm{mM}$ Tris- $\mathrm{HCl} ; 2,5 \mathrm{mM} \mathrm{MgCl}_{2} ; 200 \mu \mathrm{M}$ dNTPs; $0,2 \mu \mathrm{M}$ Primer; $2 \mathrm{U}$ AmpliTaq Gold ${ }^{\mathrm{TM}}$.

Eigenschaften: Die amplifizierte Sequenz enthält Restriktionsschnittstellen (Enzyme: CviI, NdeII, DdeI, TSP509) zur potentiellen Differenzierung der gängigen Haustierarten.

Primersystem CB 2:

Primer a: 5' - TAT TTG CAT ACG CAA TCC T -3'

Primer b: 5'- TCC AAT TCA TGT GAG TGT TA-3'

Position: 824-1017

Länge: 194 bp

Amplifikationsbedingungen: $94^{\circ} \mathrm{C} 1 \mathrm{~min}, 56^{\circ} \mathrm{C} 1 \mathrm{~min}, 72^{\circ} \mathrm{C} 1 \mathrm{~min}$

$60 \mathrm{mM} \mathrm{KCl} ; 12 \mathrm{mM}$ Tris-HCl; 2,5mM $\mathrm{MgCl}_{2} ; 150 \mu \mathrm{M}$ dNTPs; 0,18$\mu \mathrm{M}$ Primer; $2 \mathrm{U}$ AmpliTaq Gold ${ }^{\mathrm{TM}}$.

Eigenschaften: Die amplifizierte Sequenz enthält Restriktionsschnittstellen zur Differenzierung der Spezies Homo sapiens, Ovis aries, Capra hircus, Bos taurus, Cervus elaphus, Capreolus capreolus, u.a.

Primersystem CB3

Primer a: 5'TCT AAC AAT CCC TCA GGA AT 3'

Primer b: 5'GTG TAG TTG TCT GGG TCT CC 3'

Position: 613-770 
Länge: $158 \mathrm{bp}$

Amplifikationsbedingungen: $94^{\circ} \mathrm{C} 1 \mathrm{~min} ., 56^{\circ} \mathrm{C} 1 \mathrm{~min} ., 72^{\circ} \mathrm{C} 1 \mathrm{~min}$.

$60 \mathrm{mM} \mathrm{KCl} ; 12 \mathrm{mM}$ Tris-HCl; $2.5 \mathrm{mM} \mathrm{MgCl} 2 ; 150 \mu \mathrm{M}$ dNTPs; $0.18 \mu \mathrm{M}$ jeder Primer; 2U AmpliTaq Gold ${ }^{\mathrm{TM}}$

Eigenschaften: Das Primersystem amplifiziert eine große Bandbreite von Mammalia-Spezies.

Primersystem CB7

Primer u: 5'GCG TAC GCA ATC TTA CGA TCA A 3'

Primer 1: 5'CTG GCC TCC AAT TCA TGT GAG 3'

Position: 829-1023

Länge: 195 bp

Amplifikationsbedingungen: $94^{\circ} \mathrm{C} 1 \mathrm{~min}, 62^{\circ} \mathrm{C} 1 \mathrm{~min}, 72^{\circ} \mathrm{C} 1 \mathrm{~min}$

$60 \mathrm{mM} \mathrm{KCl} ; 12 \mathrm{mM}$ Tris-HCl; 2,5mM $\mathrm{MgCl}_{2} ; 150 \mu \mathrm{M}$ dNTPs; $0,18 \mu \mathrm{M}$ Primer; $2 \mathrm{U}$ AmpliTaq Gold ${ }^{\mathrm{TM}}$.

Eigenschaften: Die amplifizierte Sequenz enthält Restriktionsschnittstellen zur Differenzierung der Spezies Homo sapiens, Ovis aries, Capra hircus Bos taurus, Cervus elaphus, Capreolus capreolus, u.a. Bei CB7 handelt es sich um eine Modifikation des Systems CB2.

Ein mitochondriales Primerpaar wurde direkt aus der Literatur übernommen:

Primersystem cyt b (nach Hardy et al. 1997)

Primer a: 5'-CTC CAC ACA TCC AAA CAA CG-3'

Primer b: 5'-TGT TCG ACT GGT TGT CCT CC-3'

Position: 919 bis 1034

Länge: 116 Basenpaare 
Amplifikationsbedingungen: $94^{\circ} \mathrm{C} 1 \mathrm{~min}, 51^{\circ} \mathrm{C} 1 \mathrm{~min}, 72^{\circ} \mathrm{C} 1 \mathrm{~min}$

$60 \mathrm{mM} \mathrm{KCl} ; 12 \mathrm{mM}$ Tris-HCl; 2,5mM $\mathrm{MgCl}_{2} ; 175 \mu \mathrm{M}$ dNTPs; $0,36 \mu \mathrm{M}$ Primer; $2 \mathrm{U}$ AmpliTaq Gold ${ }^{\mathrm{TM}}$.

Eigenschaften: Der Primer passt v.a. auf Mammalia-Genome.

\subsection{Primertabellen}

Tabelle 4: Primer, mitochondriale DNA

\begin{tabular}{|l|l|l|l|l|}
\hline Primer & Länge & Sequenz & $\begin{array}{l}\text { Position* } \\
\text { mtDNA }\end{array}$ & $\begin{array}{l}\text { Position } \\
\text { Cyt B }\end{array}$ \\
\hline CB1a & 22 & GATGGAATTTCGGTTCCCTCCT & $14602-14623$ & $89-110$ \\
\hline CB1b & 22 & CGTATCCTATGAATGCTGTGGC & $14886-14907$ & $373-394$ \\
\hline CB2a & 19 & TATTTGCATACGCAATCCT & $15337-15355$ & $824-842$ \\
\hline CB2b & 20 & TCCAATTCATGTGAGTGTTA & $15511-15530$ & $998-1017$ \\
\hline CB3a & 20 & TCTAACAATCCCTCAGGAAT & $15126-15145$ & $613-632$ \\
\hline CB3b & 20 & GTGTAGTTGTCTGGGTCTCC & $15264-15283$ & $751-770$ \\
\hline CB7u & 23 & GCGTACGCAATCTTACGATCAA & $15342-15364$ & $829-850$ \\
\hline CB71 & 21 & CTGGCCTCCAATTCATGTGAG & $15516-15536$ & $1003-1023$ \\
\hline CyBa & 24 & GAATCTGCCTAATCCTACAAATCC & $14626-14649$ & $113-136$ \\
\hline CyBb & 22 & CTCCGTTTGCGTGTATGTATCG & $14751-14772$ & $238-259$ \\
\hline CytL & 20 & CTCCACACATCCAAACAACG & $15432-15451$ & $919-938$ \\
\hline CytH & 20 & TGTTCGACTGGTTGTCCTCC & $15528-15547$ & $1015-1034$ \\
\hline rR4a & 23 & AACTGGGATTAGATACCCCACTA & $844-866$ & - \\
\hline rR4b & 22 & CGATTATAGGACAGGCTCCTCT & $972-993$ & - \\
\hline rR4c & 18 & GAAGCACCGCCAAGTCCT & $944-961$ & - \\
\hline
\end{tabular}

*Referenzsequenzen: JO1394 (B. taurus) und NC001567 (B. taurus)

Tabelle 5: Primersysteme. Name, Position und Länge des Amplifikats

\begin{tabular}{|l|l|l|}
\hline Primersystem & Position & Produktlänge (bp) \\
\hline CB1 & $14602-14907$ & 306 \\
\hline CB2 & $15337-15530$ & 194 \\
\hline CB3 & $15126-15283$ & 158 \\
\hline CB7 & $15342-15536$ & 195 \\
\hline CyB & $14626-14772$ & 147 \\
\hline Cyt & $15432-15547$ & 116 \\
\hline rR4ac & $844-961$ & 118 \\
\hline rR4ab & $844-993$ & 150 \\
\hline
\end{tabular}




\subsubsection{Chloroplasten-DNA (cpDNA) - Der rbcL locus}

Das Gen codiert die große Untereinheit von Ribulose 1,5-biphosphat Carboxylase und ist Bestandteil eines Enzyms, das den Umbau von $\mathrm{CO}_{2}$ und Ribulose 1,5Biphosphat in zwei 3-Phosphoglyzerate katalysiert. Die Untereinheit ist $1400 \mathrm{bp}$ lang (Annals of the Missouri Botanical Gardens 1993).

Primer rbcLB:

rbcLB 478: 5'-GAT AAA TTG AAC AAG TAT GGT CGT CC-3'

rbcLB 724R: 5'-CTT CGC ATG TAC CTG CAG TAG C-3'

Position: 478-724

Länge: $247 \mathrm{bp}$

Amplifikationsbedingungen: $94^{\circ} \mathrm{C} 1 \mathrm{~min}, 53^{\circ} \mathrm{C} 1 \mathrm{~min}, 72^{\circ} \mathrm{C} 1 \mathrm{~min}$

$60 \mathrm{mM} \mathrm{KCl} ; 12 \mathrm{mM}$ Tris-HCl; 2,5mM $\mathrm{MgCl}_{2} ; 175 \mu \mathrm{M}$ dNTPs; 0,36 $\mu \mathrm{M}$ Primer; $2 \mathrm{U}$ AmpliTaq Gold ${ }^{\mathrm{TM}}$.

Eigenschaften: Der Primer passt theoretisch auf fast alle Spezies der höheren Pflanzen.

\subsubsection{Nukleare DNA}

Folgende Microsatelliten-Primersysteme wurden für die Analyse von Rind, Schaf, Ziege, Huhn und Schwein aus der Literatur übernommen:

Hel 1, Chromosom 15, CA-repeat, (Kaukinen \& Varvio 1993)

Primer a: 5'-AGG CTA CAG TCC ATG GGA TT-3'

Primer b: 5'-CAA CAG CTA TTT AAC AAG GA-3

Mittlere Länge: 110 Basenpaare

Amplifikationsbedingungen: $60 \mathrm{mM} \mathrm{KCl} ; 12 \mathrm{mM}$ Tris- $\mathrm{HCl} ; 2,5 \mathrm{mM} \mathrm{MgCl} 2 ; 200 \mu \mathrm{M}$ dNTPs; 0,1 $\mu \mathrm{M}$ Primer; 2U AmpliTaq Gold ${ }^{\mathrm{TM}}$. 
Eigenschaften: Der Primer passt auf viele Mammalia ist aber speziell auf Bos taurus und phylogenetisch Verwandte angepasst, wo er einen Microsatelliten-locus amplifiziert.

Hel 5, Chromosom 21, CA-repeat, (Kaukinen \& Varvio 1993)

Primer a: GCA GGA TCA CTT GTT AGG GA -3'

Primer b: 5'- AGA CGT TAG TGT ACA TTA AC -3'

Mittlere Länge: 161 Basenpaare

Amplifikationsbedingungen:

$60 \mathrm{mM} \mathrm{KCl} ; 12 \mathrm{mM}$ Tris-HCl; $2,5 \mathrm{mM} \mathrm{MgCl}_{2} ; 200 \mu \mathrm{M}$ dNTPs; $0,1 \mu \mathrm{M}$ Primer; $2 \mathrm{U}$ AmpliTaq Gold ${ }^{\mathrm{TM}}$.

Eigenschaften: Der Primer passt auf viele Mammalia ist aber speziell auf Bos taurus und phylogenetisch Verwandte angepasst, wo er einen Microsatelliten-locus amplifiziert.

OarCP34, Chromosom 3, GT-repeat, (Ede et al. 1994)

Primer a: 5'-GGG ACA ATA CTG TCT TAG ATG CTG C -3'

Primer b: 5'- GCT GAA CAA TGT GAT ATG TTC AGG-3'

Mittlere Länge: 120 Basenpaare

Amplifikationsbedingungen:

$60 \mathrm{mM} \mathrm{KCl} ; 12 \mathrm{mM}$ Tris- $\mathrm{HCl} ; 2,5 \mathrm{mM} \mathrm{MgCl} 2 ; 200 \mu \mathrm{M}$ dNTPs; $0,08 \mu \mathrm{M}$ Primer; $2 \mathrm{U}$ AmpliTaq Gold ${ }^{\mathrm{TM}}$.

Eigenschaften: Der Primer passt auf viele Mammalia ist aber speziell auf Ovis aries und phylogenetisch Verwandte angepasst, wo er einen Microsatelliten-locus amplifiziert. 
McW43, Chromosom 4, (Crooijmans et al. 1995)

Primer a: 5'-TGA CTA CTT TGA TAC GCA TGG AGA-3'

Primer b: 5'-CAC CAA GTA GAC GAA AAC ACA TTT-3'

Mittlere Länge: 147 Basenpaare

Amplifikationsbedingungen:

$60 \mathrm{mM} \mathrm{KCl} ; 12 \mathrm{mM}$ Tris-HCl; 2,5mM MgCl $2 ; 200 \mu \mathrm{M}$ dNTPs; $0,08 \mu \mathrm{M}$ Primer; 2U AmpliTaq Gold ${ }^{\mathrm{TM}}$.

Eigenschaften: Der Primer passt auf viele Mammalia ist aber speziell auf gallus gallus und phylogenetisch Verwandte angepasst, wo er einen Microsatelliten-locus amplifiziert.

Für die folgenden beiden Primer wurde ein Duplex-Protokoll entwickelt:

Primer HUJ616, (Barendse \& Armitage 1994)

Primer a: 5'AAA CTA CAC ATT GAC AGG G 3'

Primer b: 5'GGA CCT TTG GCA ATG GAA GG 3'

Primer CSSM31 (Moore \& Byrne 1994)

Primer a: 5'CCA AGT TTA GTA CTT GTA AGT AGA 3'

Primer b: 5'GAC TCT CTA GCA CTT TAT CTG TGT 3'

Eigenschaften: Bei beiden Primersystemen handelt es sich um ursprünglich bovine Microsatelliten, die allerdings auch für Schaf und Ziege polymorph sind. Amplifikationsbedingungen Duplex: $94^{\circ} \mathrm{C} 1 \mathrm{~min}, 58^{\circ} \mathrm{C} 1 \mathrm{~min}, 72^{\circ} \mathrm{C} 1 \mathrm{~min}$ $60 \mathrm{mM} \mathrm{KCl} ; 12 \mathrm{mM}$ Tris-HCl; $2 \mathrm{mM} \mathrm{MgCl}_{2} ; 175 \mu \mathrm{M}$ dNTPs; $0,2 \mu \mathrm{M}$ Primer; $1,5 \mathrm{U}$ AmpliTaq Gold ${ }^{\mathrm{TM}}$. 
ISAG-Primersysteme (vgl. Pfeiffer \& Brenig 1998, Burger et al. 2000a)

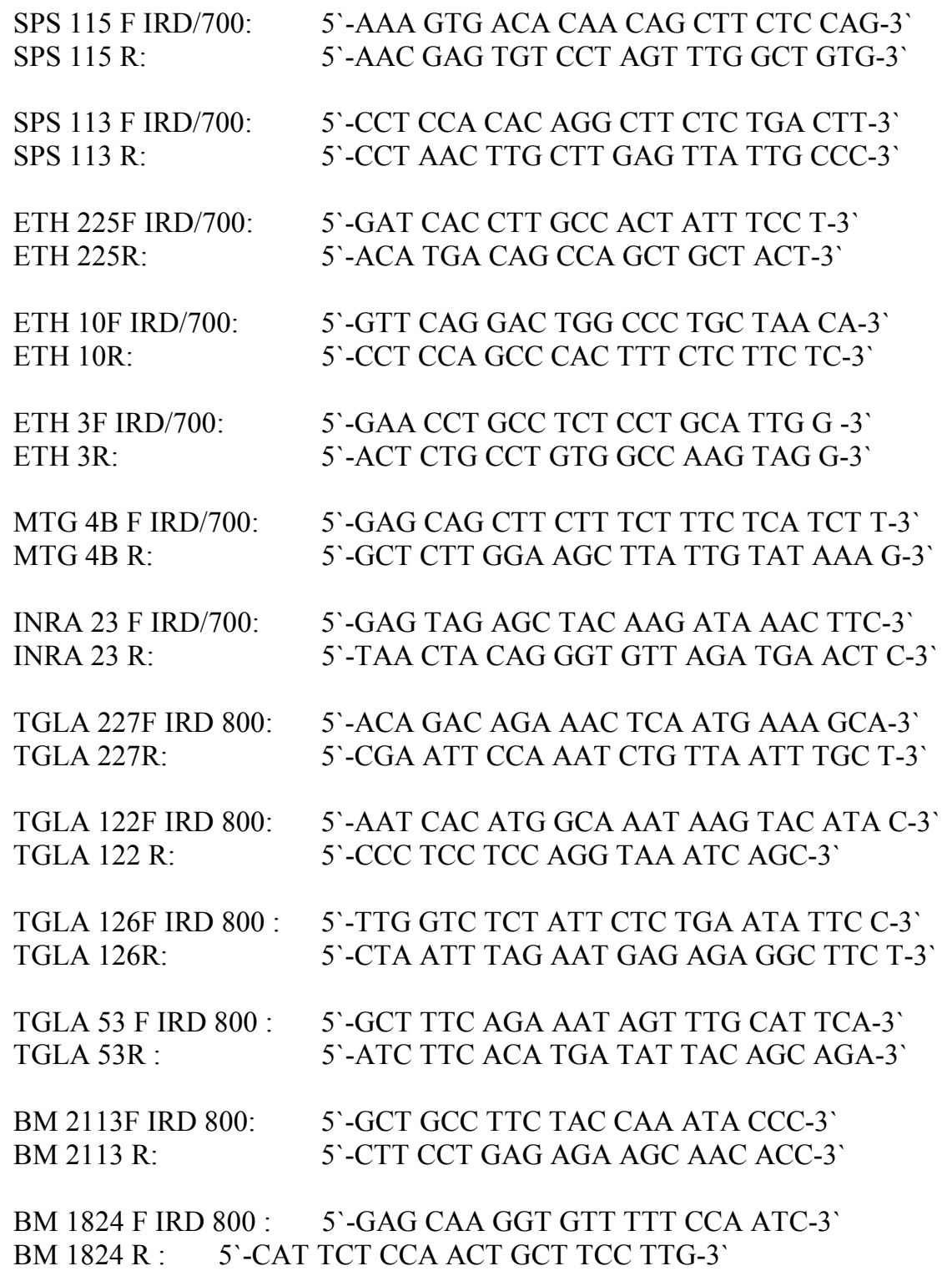

Eigenschaften: Die Primer amplifizieren Microsatelliten-loci und sind speziell zur Identifikation in der Rinderzucht entwickelt.

Die Primer wurde in unterschiedlichen Kombinationen zu Multiplex-Ansätzen verwendet.

Amplifikationsbedingungen: $94^{\circ} \mathrm{C} 1 \mathrm{~min}, 50-56^{\circ} \mathrm{C} 30 \mathrm{sec}, 72^{\circ} \mathrm{C} 1 \mathrm{~min}, 10 \mathrm{~min}$ finale Elongation. 
$50 \mathrm{mM} \mathrm{KCl} ; 10 \mathrm{mM}$ Tris-HCl pH 9; $2 \mathrm{mM} \mathrm{MgCl}_{2} ; 200 \mu \mathrm{M}$ dNTPs; $0,2 \mu \mathrm{M}$ je Primer; 1,5U AmpliTaq Gold ${ }^{\mathrm{TM}}$.

Die Allelbereiche der erfolgreich amplifizierten ISAG-STRs sind Tabelle 10 (Kapitel 5.2.1.3, S. 66ff) zu entnehmen.

Folgende Primersysteme wurden zur Amplifikation humaner Microsatelliten-DNA verwendet:

Duplex-Amplifikation HUMVWA31A/HUMFESFPS

Amplifikationsbedingungen Duplex: $94^{\circ} \mathrm{C} 1 \mathrm{~min}, 51^{\circ} \mathrm{C} 1 \mathrm{~min}, 72^{\circ} \mathrm{C} 1 \mathrm{~min}$

$60 \mathrm{mM} \quad \mathrm{KCl} ; \quad 12 \mathrm{mM}$ Tris-HCl; $2 \mathrm{mM} \quad \mathrm{MgCl}_{2} ; 175 \mu \mathrm{M} \quad \mathrm{dNTPs} ; \quad 0,14 \mu \mathrm{M}$ HUMVWA31A (Hex) (Kimpton et al. 1992); 0,2 $\mu$ M HUMFESFPS (6-Fam) (Polymeropoulus 1991); 2,5U AmpliTaq Gold ${ }^{\mathrm{TM}}$.

Multiplex-Amplifikation mit dem AmpFlSTR Profiler Plus Kit (PE Biosystems, vgl. Hummel et al. 1999a)

Amplifikationsbedingungen Multiplex: $94^{\circ} \mathrm{C} 1 \mathrm{~min}, 59^{\circ} \mathrm{C} 1 \mathrm{~min}, 72^{\circ} \mathrm{C} 1 \mathrm{~min}, 35$ Zyklen und abschließende $45 \mathrm{~min}$ bei $60^{\circ} \mathrm{C}$

$10 \mu 1$ AmpFlSTR PCR Reaction Mix ${ }^{\mathrm{TM}}$, $5 \mu 1$ AmpFlSTR Profiler Plus Primer Set $^{\mathrm{TM}}$, 2.5 U AmpliTaq Gold ${ }^{\mathrm{TM}}, 5 \mu 1$ DNA-Extrakt, $5 \mu 1$ Ampuwa ${ }^{\circledR}$ (Fresenius) 


\subsection{Restriktionsfragment-Längenpolymorphismus von PCR- Produkten (PCR-RFLP)}

Auf den Cytochrom b -Sequenzen von Rind, Ziege, Schaf, Hirsch, Reh und Mensch wurden Abschnitte gewählt, die polymorphe Restriktionsstellen enthalten. Daraufhin wurden die Primersysteme CB2 (194 bp), und CB1 (306 bp) und CB7 (195 bp) konzipiert. Die Bestimmung der Restriktionsfragmentlängen erfolgte mit dem Programm DNasis V2.0 (Hitachi Ltd. 1992). Folgende Enzyme und Protokolle kamen zur Anwendung (graphisch dargestellt sind die Schnittstellen für die oben genannten Spezies):

\subsubsection{TSP509}

(Schnittstellen s. Abb. 5)

TSP509: 5' - ^AATT -3’ bzw. 3'- TTAA^ -5' (New England Biolabs)

Puffer: $2 \mu \mathrm{l}$; PCR-Produkt $7 \mu 1$; Enzym: $12 \mathrm{U}$; $2 \mathrm{~h}$ bei $65^{\circ} \mathrm{C}$

\section{$\underline{\text { Ovis aries }}$}

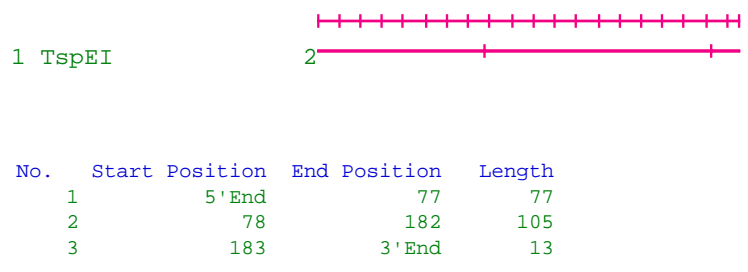

$\underline{\text { Capra hircus }}$

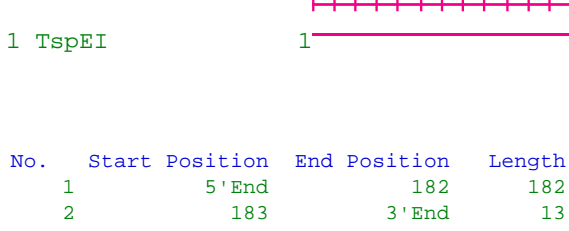

$\underline{\text { Bos taurus }}$

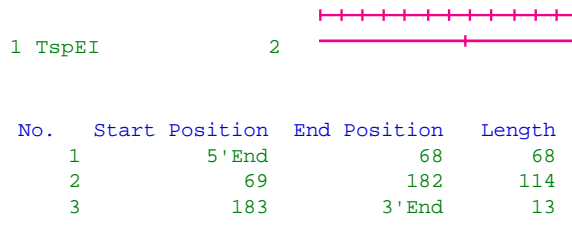




\section{Cervus elaphus}

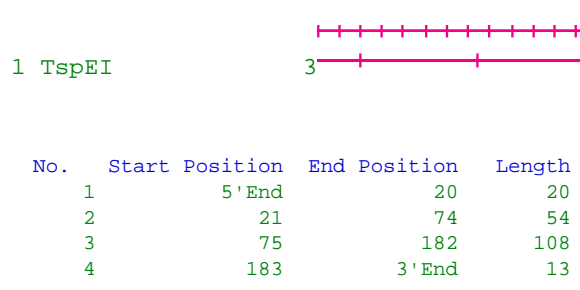

\section{$\underline{\text { Capreolus capreolus }}$}

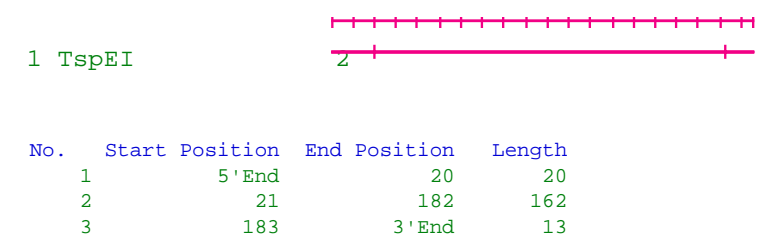

$\underline{\text { Homo sapiens }}$

1 TspEI

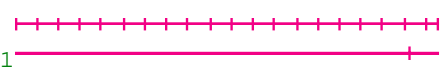

$\begin{array}{rrrr}\text { No. Start Position } & \text { End Position } & \text { Length } \\ 1 & 5 \text { 'End } & 182 & 182 \\ 2 & 183 & 3^{\prime} \text { End } & 13\end{array}$

Abbildung 5: TSP509-Schnittstellen des CB7-locus der Spezies Ovis aries (Schaf), Capra hircus (Ziege), Bos taurus (Rind), Cervus elaphus (Hirsch), Capreolus capreolus (Reh) und Homo sapiens (Mensch) 


\subsubsection{NdeII}

(Schnittstellen s. Abb. 6)

Nde II: 5'- ^GATC -3' bzw. 3'- GATC^ ${ }^{\wedge} 5^{\prime}$ (Boehringer)

Puffer: $2 \mu \mathrm{l}$; PCR-Produkt $5 \mu \mathrm{l}$; Enzym: $15 \mathrm{U}$; $2 \mathrm{~h}$ bei $37^{\circ} \mathrm{C}$

(Ein Isoschizomer zu NdeII ist: Sau 3AI: $5^{\prime}-{ }^{\wedge}$ GATC $-3^{\prime}$ bzw. $3^{\prime}-$ GATC $^{\wedge}-5^{\prime}$ (New England Biolabs)

\subsubsection{Duplex DdeI und NdeII}

(Schnittstellen s. Abb. 6)

Dde I : $5^{\prime}-\mathrm{C}^{\wedge}$ TNAG $-3^{\prime}$ bzw. $3^{\prime}-\mathrm{GANT}{ }^{\wedge} \mathrm{C}-5^{\prime}$ (New England Biolabs)

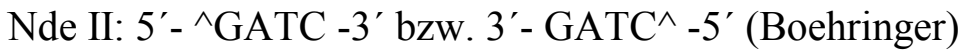

Puffer: $1,2 \mu 1$ Puffer DdeI $+1,2 \mu 1$ Puffer NdeII; $4 \mu 1$ PCR-Produkt

16U DdeI, $1 \mathrm{~h}$ bei $37^{\circ} \mathrm{C}$

$13 \mathrm{U}$ NdeII, $1,5 \mathrm{~h}$ bei $37^{\circ} \mathrm{C}$

Alle Reaktionen wurden mit einem Tropfen Öl überschichtet. Die Auftrennung der Fragmente erfolgte auf Agarosegel (2,5\%, 2,5h). Die Restriktionsanalysen wurden exemplarisch an Tierknochen aus der Lichtensteinhöhle (Rind, Ziege, Schaf und morphologisch nicht eindeutig zwischen Schaf und Ziege unterscheidbare Knochenelemente, vgl. Tabelle 1, Kap. 4.2.1.1, S. 17), an der in Kapitel 4.2.7 (S. 33) beschrieben forensischen Probe und an Rezentproben durchgeführt. Die Ergebnisse hierzu finden sich in Kapitel 5.1.2. (S. 58ff). 


\section{Ovis aries}

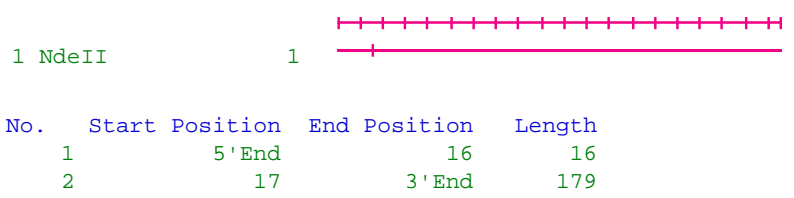

Capra hircus

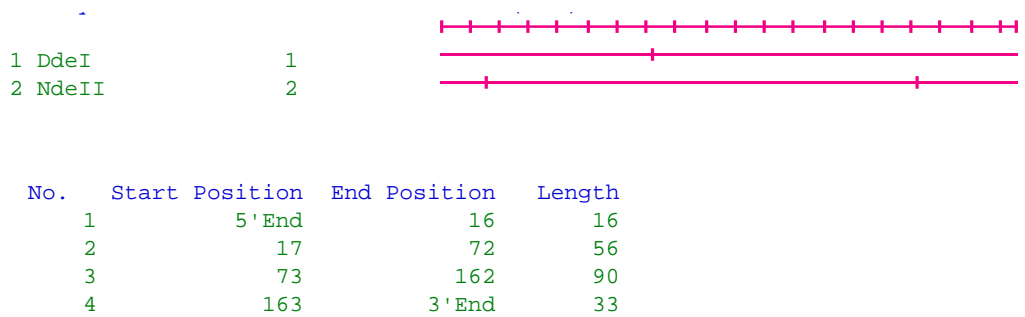

Bos taurus

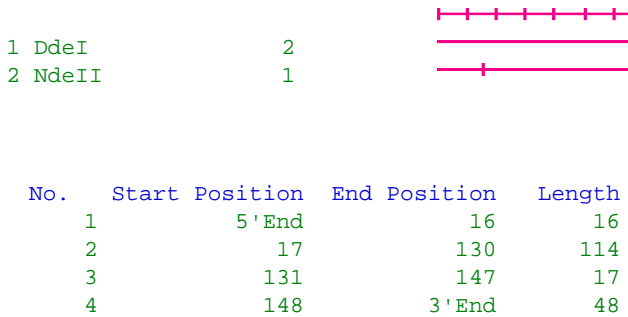

\section{Cervus elaphus}

1 DdeI

2 NdeII

No.

$\begin{array}{lr} & \text { Start Position } \\ 1 & 5 \\ 2 & 17 \text { En } \\ 3 & 46 \\ 4 & 154 \\ 5 & 163\end{array}$

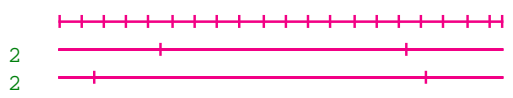

Length

$\begin{array}{rr}16 & 16 \\ 45 & 29 \\ 153 & 108 \\ 162 & 9 \\ \text { 3'End } & 33\end{array}$

$\underline{\text { Capreolus capreolus }}$
1 NdeII

No.

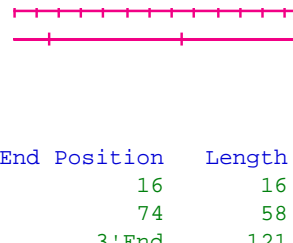




\section{Homo sapiens}
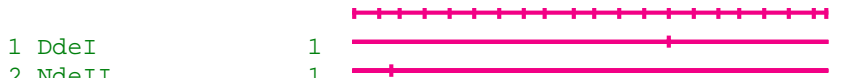

No.

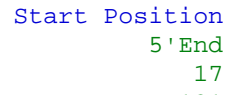

Abbildung 6: DdeI- und NdeII-Schnittstellen des CB7-locus der Spezies Ovis aries (Schaf), Capra hircus (Ziege), Bos taurus (Rind), Cervus elaphus (Hirsch), Capreolus capreolus (Reh) und Homo sapiens (Mensch).

Abbildung 7 (nächste Seite) zeigt das alignment von acht Spezies für den CB7 locus mit den beiden Primern. Der locus besitzt hohe Variabilität für die Sequenzen, die zwischen den Primern liegen und gute Primerpasstellen für die Spezies Ovis aries (Schaf), Ovis musonii (Mufflonschaf), Capra hircus (Ziege), Bos taurus (Rind). Weniger gut sind die Passtellen für Cervus elaphus (Rothirsch) und Capreolus capreolus (Reh). Schlechte Passtellen besitzen Homo sapiens und Gallus gallus (Haushuhn). 


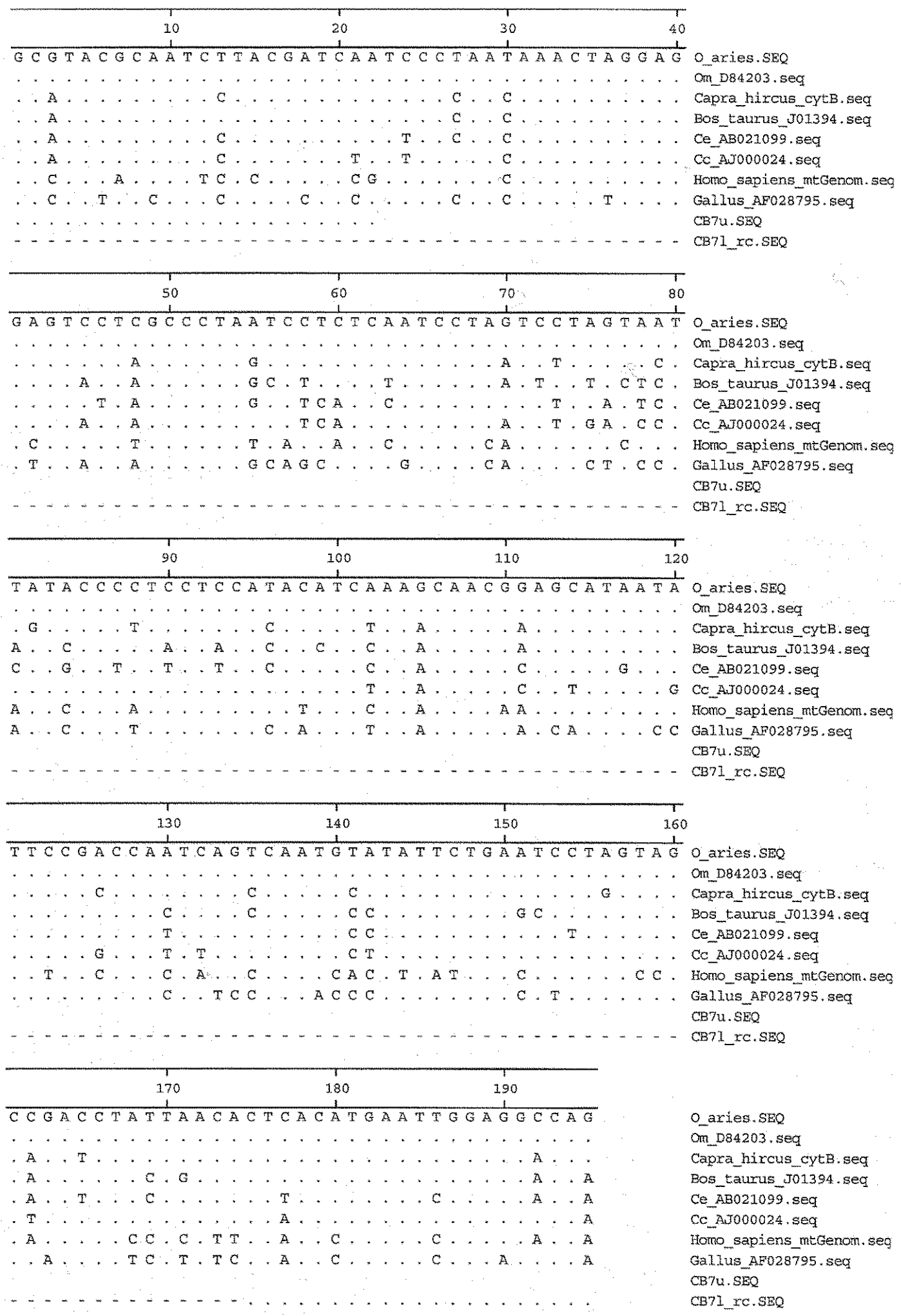

Abbildung 7: Alignment der Referenzsequenzen verschiedener Spezies zwischen Primern CB7u und CB7l (Ovis aries $=$ Schaf, Om: Ovis musonii $=$ Mufflonschaf, Bos taurus $=$ Rind, Capra hircus $=$ Ziege, Ce: Cervus elaphus = Rothirsch, Cc: Capreolus capreolus $=$ Reh, Gallus: Gallus gallus $=$ Haushuhn). 


\subsection{Agarose Gelelektrophorese}

Der Nachweis der PCR-Produkte und der PCR-RFLP-Produkte fand auf 2,5\% Agarosegel statt. Die Auftrennung von 10 $\mu$ l PCR-Produkten erfolgte auf etwa $4 \mathrm{~mm}$ starken Gelen, die mit $3 \mu 1$ 1\% w/v Ethidiumbromid gefärbt waren. Als Gelund Laufpuffer wurde 1xTBE-Puffer (90mM Tris, 90mM Borsäure, 2,5mM EDTA, pH 8,3) verwendet. Die DNA-Extrakte wurden mit 1,5 $\mu 1$ Schwerelösung (0,25\% w/v Bromphenolblau; $40 \% \mathrm{w} / \mathrm{v}$ Sacharose, Ampuwa $\left.{ }^{\circledR}\right)$ versetzt und auf das Gel aufgetragen. Nach einer Laufzeit von etwa 1 h (RFLP: 2,5 h) bei 100V und 20-30 mA wurden die Gele im UV-Durchlicht (254nm) unter Verwendung eines Orange-Filters photographiert (Polaroid ${ }^{\mathrm{TM}}$ Film 667; Blende 11, 3 sec, Polaroid $^{\mathrm{TM}}$ Landkamera MP4).

\subsection{Aufreinigung von PCR-Produkten}

PCR-Produkte wurden vor der Sequenzierreaktion, dem sogenannten Cycle Sequencing (s.u.), von ihren Puffersalzen, überschüssigen Primern, dNTPs und Polymerase mithilfe des kommerziellen QIAquick PCR Purification Kits getrennt. Das Prinzip beruht auf einer Zentrifugationssäulentechnik mit einer Silikagelmembran, die selektiv größere Mengen und Längen von Nucleinsäuren bindet. Während die DNA an die Membran bindet, werden Oligonucleotide kleiner als 50 bp, Salze und andere Moleküle abzentrifugiert.

30-40 $\mu 1$ PCR-Produkt wurde in den Vorgang eingesetzt, wobei sich das Protokoll genau nach den Angaben des Herstellers richtete. Das Elutionsvolumen entsprach dem Ausgangsvolumen.

\subsection{DNA Cycle Sequencing von PCR-Produkten}

Das sogenannte Cycle Sequencing basiert auf der enzymatischen Reaktion nach Sanger (Sanger et al. 1977). Das Prinzip des Cycle Sequencing von PCRProdukten ist folgendermaßen (Engelke et al. 1988): In einem Reaktionsansatz 
befinden sich die DNA-Matrize (template) in Form von gereinigten PCRProdukten (s.o.), ein Primer, die Polymerase, farbstoffmarkierte Didesoxynukleotide (ddNTPs), Tris-HCl und $\mathrm{MgCl}_{2}$. Nach 30 Sekunden thermischer Denaturierung bei $96^{\circ} \mathrm{C}$ erfolgt das Annealing des Primers bei $50-60^{\circ} \mathrm{C}$ und die 4-minütige Phase der Extension. Bei der Extension bauen sich sowohl unmarkierte dNTPs als auch markierte ddNTPs ein, wobei letztere zum Extensionsabbruch führen. Da die vier Didesoxynukleotide mit unterschiedlichen Farbstoffen markiert sind $\left(3^{\prime}\right.$-dye terminators) kann die Reaktion in einem Ansatz stattfinden (Smith et al. 1986). BigDyes bestehen aus dem Energiedonor Fluoreszin und dem daran gebundenen Akzeptor Dichlorrhodamin (Lee et al. 1997).

Nach dem Cycle Sequencing werden die Produkte von überschüssigen Reaktionskomponenten gereinigt und volumenmäßig gefällt. Der komplette Cycle Sequencing-Ansatz wird mit 50 41 95\% EtOH und $2 \mu 13 \mathrm{M} \mathrm{NaOAc} \mathrm{pH} \mathrm{4,6} \mathrm{gefällt} \mathrm{und} \mathrm{da-}$ nach bis zur Pelletierung zentrifugiert. Das Pellet wird mit 70 \% EtOH gewaschen und durch Zentrifugation erneut pelletiert. Das getrocknete Pellet wird in $20 \mu 1$ TSR-Puffer (PE Biosystems) aufgenommen und ist nach 2-minütiger Denaturierung bei $90^{\circ} \mathrm{C}$ bereit für die Injizierung in die Kapillar-Elektrophorese.

Das Protokoll für die Sequenzierung mit der Plattengelelektrophorese ist identisch mit der Ausnahme, daß das Pellet zuletzt in $1 \mu 1$ Ladepuffer (Formamid; $50 \mathrm{mg} / \mathrm{ml}$ Dextran blau in 25mM EDTA, PE Biosystems) aufgenommen wird.

\subsection{Kapillar-Elektrophorese für die DNA-Sequenzierung}

Bei der Kapillarelektrophorese (ABI Prism 310 Genetic Analyzer) werden die markierten Produkte über einen Autosampler in eine mit Polymer (Pop 6, PE Biosystems) gefüllte Kapillare injiziert. Die markierte DNA wird - ebenso wie beim Gel - in der Kapillare elektrophoretisch nach der Länge aufgetrennt und passiert dabei ein Fenster, wo die Fluoreszenzstoffe, durch einen Laser angeregt, Licht unterschiedlicher Wellenlänge emittieren. Das spektrographisch separierte Licht wird mit einer CCD-Kamera aufgenommen und von der „collection software“ als elektrisches Signal gespeichert. Diese Daten werden mit der Analyse-Software 
ABI Prism ${ }^{\mathrm{TM}}$ Sequenzing Analysis ${ }^{\mathrm{TM}} 3.0$ (PE Biosystems) zu vierfarbigen Elektropherogrammen verrechnet. Die Elektropherogramme repräsentieren die Basen der DNA durch peaks in unterschiedlichen Farben.

\subsection{Kapillar-Elektrophorese für die Fragmentlängendetektion}

Das Protokoll für die Kapillar-Elektrophorese für die Fragmentlängendetektion mit dem ABI Prism 310 Genetic Analyzer ist identisch mit dem für die Sequenzierung, mit den Ausnahmen, daß für die Fragmentlängendetektion das Polymer Pop 4 und für die Analyse das Programm GenScan (PE Biosystems) verwendet wurde.

\subsection{Plattengelelektrophorese für die Fragmentlängendetektion}

Längenbestimmung von Dinucleotid-Microsatellitenfragmenten wurden auf dem automatischen Sequenzer LICOR 4000L vorgenommen. Die Auftrennung erfolgte auf einem $8 \%$ und 2,5mM Gel Polyacylamidgel. Die Daten wurden mithilfe der Software Scanalytics 3.3 Plus verrechnet.

\subsection{Plattengelelektrophorese für die Sequenzierung}

Für die Plattengelelektrophorese auf dem Automated Sequenzer ABI 373 (PE Biosystems) mit dem Gelsystem 24/12cm WTR (50 B/h) wurde ein $6 \%$ Polyacrylamidgel / 8 M Harnstoff hergestellt. Dabei wurde, wie bei allen Reaktionen und Ansätzen im Zusammenhang mit Fluoreszenzdetektionssystemen reines HPLC$\mathrm{H}_{2} \mathrm{O}$ verwendet. Reguläre Laufbedingungen für Sequenzierprodukte bis 200 bp: 27 Watt, $5 \mathrm{~h}$. 


\subsection{Erfassung und Auswertung von DNA-Sequenzdaten}

Sowohl bei der Kapillar- als auch bei der Plattengelelektrophorese erfolgte die Sequenzerfassung EDV-gestützt mithilfe der Programme ABI Prism ${ }^{\mathrm{TM}}$ Collection Software und ABI Prism ${ }^{\mathrm{TM}}$ Sequenzing Analysis ${ }^{\mathrm{TM}} 3.0$ (PE Biosystems). Während die Collection Software allein für die Datenaufnahme und die Kommunikation mit dem automatischen Sequenzer zuständig ist, besorgt Sequenzing Analysis ${ }^{\mathrm{TM}} 3.0$ die Darstellung der Sequenzierungsdaten und die Verechnung der Rohdaten in lesbare DNA-Sequenzen mithilfe des sogenannten Bascallers.

Die Bestimmungen des Bascallers wurden für alle Sequenzen überprüft und gegebenenfalls korrigiert. Im Falle von Unklarheiten wurden IUB-code-Buchstaben verwendet.

Das alignment von DNA-Sequenzen erfolgte zunächst per Hand mit dem Programm SeqApp ${ }^{\mathrm{TM}}$, dann mit dem Programm Sequence Navigator ${ }^{\mathrm{TM}}$ (PE Biosystems) und letztendlich mithilfe des Softwarepakets DNAStar. Bei letzterem wurden Sequenzen zusammen mit ihrer graphischen Auflösung in Seqman geprüft und reanalysiert, in EditSeq gespeichert und mit Megalign einem Alignment unterzogen. Ähnlichkeitsdiagramme mit vorhandenen Referenzsequenzen wurden mithilfe der Funktion „Phylogenetic Tree“ erstellt. Um taxonomische Informationen über die ermittelte Sequenz und Referenzsequenzen aus GenBank zu erhalten, wurde das Programm Blast Search (Altschul et al. 1997) benutzt. Weitere Informationen über die Phylogenie eines durch Sequenzanalyse ermittelten Taxons wurden durch einschlägige Nachschlagwerke oder das Programm Taxonomy Browser (NCBI) erlangt.

\subsection{Erfassung und Auswertung von Microsatelliten-DNA-Daten}

Unabhängig vom Detektionssystem wurden bei der Microsatellitenanalyse jeweils die beiden höchsten peaks als Allel gewertet (vgl. Burger 1997). Wenn ein deutlich dominierender peak vorhanden war, wurde das Allel als homozygot notiert. 
War die offensichtliche Stotterbande eines dominierenden peaks höher als ein weiterer hoher peak, so wurde dieser als Allel gewertet. Ein Genotyp wurde dann festgestellt, wenn mindestens drei Allelbestimmungen aus mindestens drei Amplifikationen und zwei DNA-Extraktionen vorgenommen werden konnten. Im Automated Sequenzer 310 (PE Biosystems) wurden die Rohdaten mithilfe der Software 672 Genescan-Analysis und im LICOR mit Scanalytics 3.3 Plus ausgewertet. 


\section{Ergebnisse}

\subsection{Knochen}

\subsection{1 mtDNA-Sequenzierung}

Abbildung 8 zeigt zwei aDNA Sequenzen eines prähistorischen Knochenfragments aus Texas im Vergleich mit der entsprechenden Sequenz der Spezies Odocoileus viriginianus (Trughirsch, Cervidae, Odocoileinae; Burger et al. 2000c). Die beiden aDNA Sequenzen entstammen demselben Extrakt und zwei unabhängigen PCR-Reaktionen. Beide weichen an der Position 89 von der Referenzsequenz ab (Transition $\mathrm{T}$ zu C). Die Sequenz ist in der Umgebung des Sequenzierprimers rR4a 12 bzw. 16 Basenpaare unleserlich. Die universellen Primer rR4a und rR4c passen bis auf eine Position am 5'-Ende von rR4c exakt auf die Spezies.

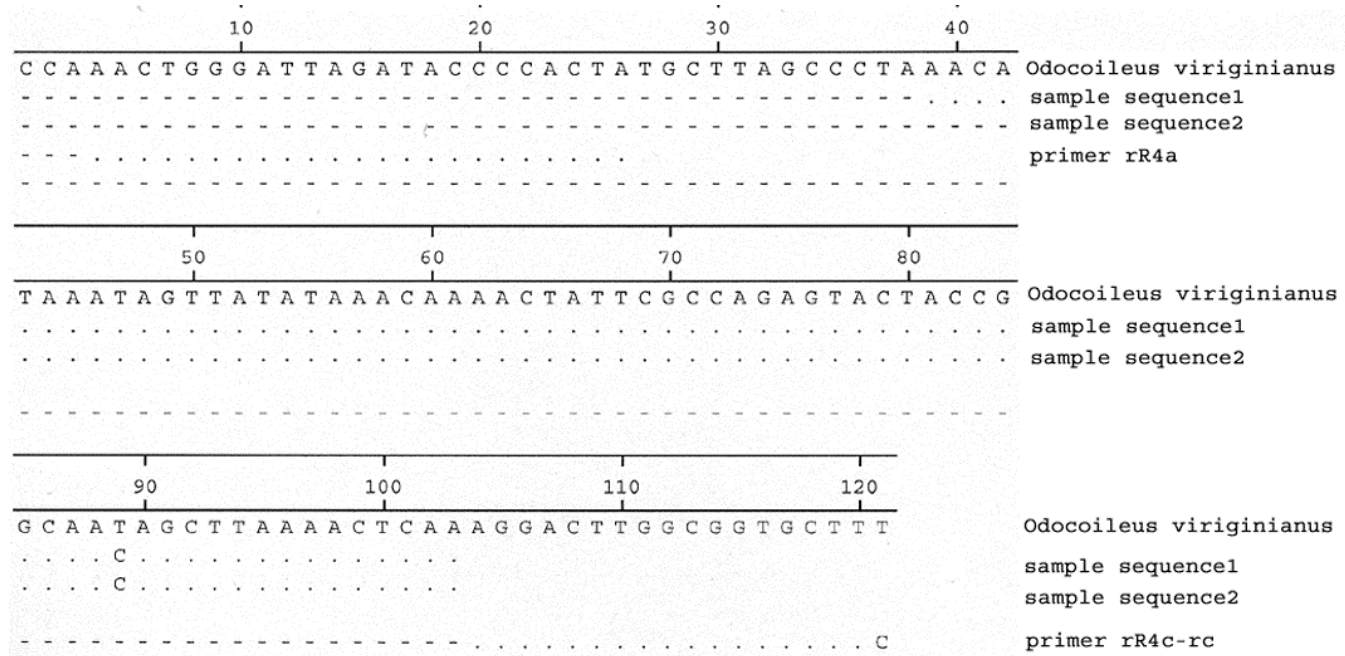

Abbildung 8: Zwei DNA-Sequenzen aus einem prähistorischen Fußknochen aus Texas (ca. 1000 BC) im Vergleich zur Referenzsequenz eines Trughirschen (white tailed deer). 


\subsubsection{PCR-RFLP}

Abbildung 9 zeigt das CB7-Amplifikationsergebnis unter stringenten $\left(\mathrm{A}: 61^{\circ} \mathrm{C}\right)$ und weniger stringenten Bedingungen (B: $54^{\circ} \mathrm{C}$ ) für die Spezies $O$. aries, $C$. hircus und B. taurus, G. gallus und H. sapiens. O. aries, C. hircus und B. taurus ergeben bei beiden annealing-Temperaturen deutliche und G. gallus keine Banden. H. sapiens zeigt unter stringenten Bedingungen kein Amplifikationsprodukt auf, bei $54^{\circ} \mathrm{C}$ zeigt sich allerdings eine schwache Bande.

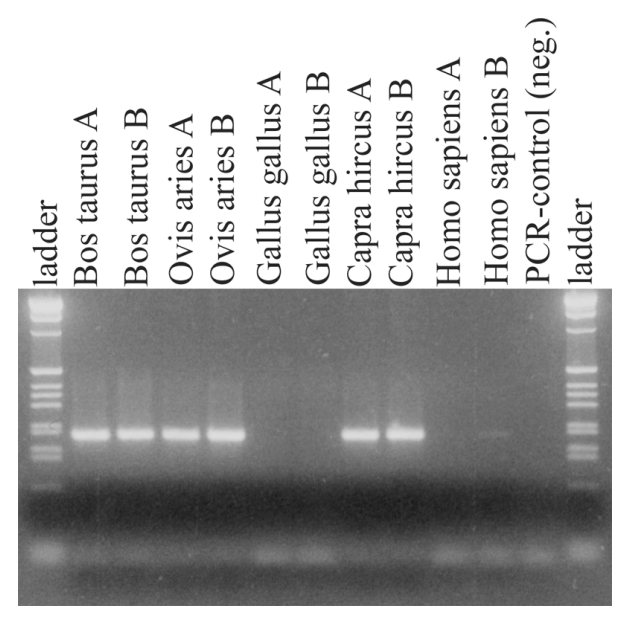

Abbildung 9: Amplifikation des CB7 locus (195bp) unterschiedlicher Spezies unter stringenten $\left(A: 61^{\circ} \mathrm{C}\right)$ und weniger stringenten $\left(B: 54^{\circ} \mathrm{C}\right)$ Bedingungen.

Abbildung 10 zeigt das CB7-Amplifikationsprodukt eines Schafs-, eines Rinds-, eines Ziegenknochens und der forensischen Probe IP $1^{3}$ nach Endonucleasebehandlung mit dem Enzym NdeII. Alle Amplifikate werden im oberen Primer nach 16bp geschnitten. Die Ziegenprobe weist darüber hinaus eine Schnittstelle an Position 162 auf, wodurch ein sichtbares, kürzeres Fragment mit 146bp Länge entsteht. Es sind somit zwar Ziege und Schaf deutlich zu unterscheiden, aber Schaf ist iden-

\footnotetext{
${ }^{3} \mathrm{Da}$ es sich in diesem Kapitel in erster Linie um die Darstellung einer Methode und nicht einer Materialgruppe handelt, wird auch die Probe IP1 hier behandelt.
} 
tisch mit Rind und somit nicht unterscheidbar. ${ }^{4}$ Die Probe IP1 verhält sich wie Schaf und Rind und hat eine Bande bei 179bp. Dies entspricht nicht den theoretisch für Hirsch oder Reh erwarteten Fragmentlängen, die sichtbare Fragmente bei 146bp bzw. 121 bp zeigen müßten (vgl. 4.4.3, S. 48f).

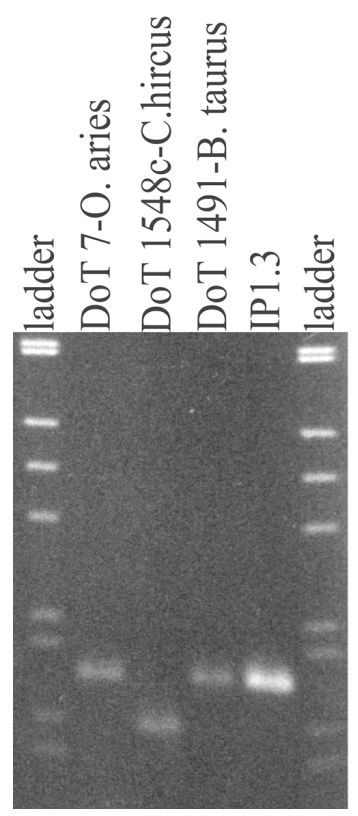

\begin{abstract}
Abbildung 10: Restriktionspolymorphismen der Restriktionsendonuclease NdeII zwischen Schaf, Ziege und Rind. Als Proben wurden mit dem Enzym TSP509 (s.u.) bereits identifizierte Knochen aus der Lichtensteinhöhle verwendet (DoT 7, 1548c, 1491). Bei der Probe IP1.3 handelt es sich um das dritte Extrakt der forensischen Probe der Jagdspur.
\end{abstract}

Abbildung 11 zeigt sechs weitere Tierproben aus der Lichtensteinhöhle mit den entsprechenden Positivkontrollen, nun nach Verdau des CB7-Amplifikats mit der Endonuclease TSP509. Jede Probe ist mit zwei Amplifikationen und Enzymreaktionen aus zwei unabhängigen DNA-Extraktionen dargestellt. Der Vergleich der alten Proben mit den Positivkontrollen daneben zeigt, um welche Spezies es sich jeweils handelt. Die empirischen Fragmentlängen stimmen mit den in der Theorie postulierten überein. Abbildung 12 verdeutlicht dies an Rezentkontrollen fünf unterschiedlicher Spezies. Während das Ursprungsprodukt 195bp lang ist, hat die

\footnotetext{
${ }^{4}$ Korrekt wäre, statt z.B. „Ziege und Schaf“ jeweils „,die Restriktionsfragmentlängenmuster von Schaf und Ziege“ zu schreiben. Im Sinne einer besseren Lesbarkeit wird im Folgenden abkürzend der Artenname als Metonym verwendet.
} 
Ziege ihre kennzeichnende Fragmenlänge bei 182bp. Das Schaf ist über die Fragmente bei $105 \mathrm{bp}$ und $77 \mathrm{bp}$, Rind bei $114 \mathrm{bp}$ und 68bp zu identifizieren. Hirsch ist gekennzeichnet durch Banden von 108bp und 54bp Länge, Reh durch eine Bande bei 162bp (vgl. 4.4.1, S. 46f). Die Probe IP1 in derselben Abbildung zeigt aus drei Extraktionen dreimal das gleiche Ergebnis. Es sind vier Banden zu beobachten, von denen jeweils zwei gleicher Länge zu sein scheinen wie die Fragmente von Rind und Schaf. Die Probe IP ist aber auf jeden Fall unterschiedlich zu Hirsch und Reh.

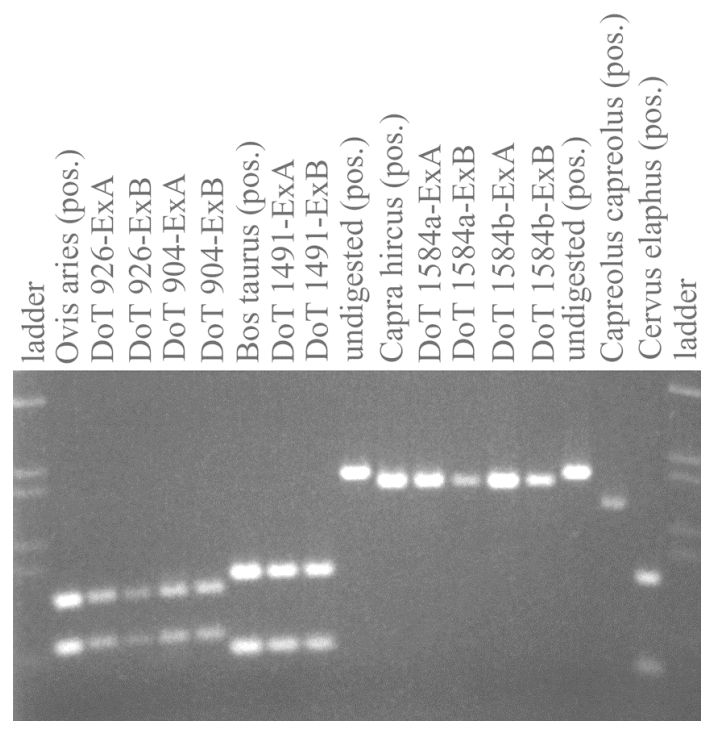

Abbildung 11: Restriktionsanalyse (TSP509) von Tierknochen aus der Lichtensteinhöhle (DoT) im Vergleich mit Rezentproben (pos.) von Schaf, Rind, Ziege, Reh und Hirsch. Jedes alte Probenindividuum wurde aus zwei unterschiedlichen DNAExtraktionen (ExA, ExB) analysiert. (undigested: Original-Amplikon ungeschnitten 195bp) 


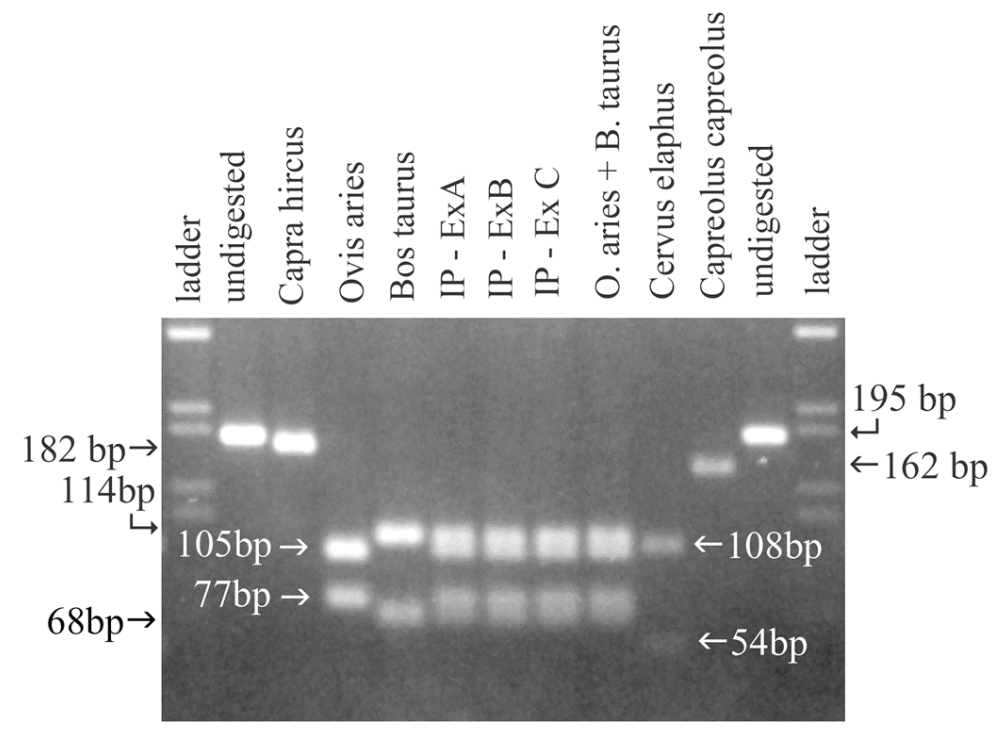

Abbildung 12: TSP 509-RFLP des CB7-locus mit Angaben der Fragmentlängen in Basenpaaren. Dargestellt sind zwischen den Allelleitern (,,ladder") v.l.n.r. ein ungeschnittenes Original-Amplikon (,,undigested“), eine Ziege, ein Schaf, ein Rind, dreimal die forensische Probe IP1 aus drei unabhängigen Extraktionen, ein 1:1 Gemisch aus PCR-Produkten von Schaf und Rind, ein Hirsch, ein Reh und ein unverdautes Amplikon.

In Tabelle 6 ist zusammenfassend der Vergleich zwischen morphologischer und molekulargenetischer Speziesbestimmung der Tierknochen aus der Lichtensteinhöhle dargestellt. Die Bestimmungen stimmen überein. In zwei Fällen war kein DNA-Ergebnis zu erzielen. In einem Fall konnte eine morphologisch unsichere Bestimmung molekulargenetisch sicher als Ziege bestimmt werden.

Tabelle 6: Morphologische und molekulargenetische Speziesbestimmung von bronzezeitlichen Tierknochen aus der Lichtensteinhöhle, Osterode am Harz, im Vergleich.

$\begin{array}{lll}\text { Probennummer } & \text { Morphologisches Taxon } & \text { Genetisches Taxon } \\ \text { DoT 926 } & \text { Ovis aries } & \text { Ovis aries } \\ \text { DoT 904 } & \text { Ovis aries } & \text { Ovis aries } \\ \text { DoT } 7 & \text { Ovis aries } & \text { Ovis aries } \\ \text { DoT 1491 } & \text { Bos taurus } & \text { Bos taurus } \\ \text { DoT 1285 } & \text { Bos taurus } & / \\ \text { DoT 1584a } & \text { Capra hircus } & \text { Capra hircus } \\ \text { DoT 1584b } & \text { Capra hircus } & \text { Capra hircus } \\ \text { DoT 1584c } & \text { Capra hircus } & \text { Capra hircus } \\ \text { DoT 1566 } & \text { Capra hircus } & \text { Capra hircus } \\ \text { DoT } 1468 & \text { C. hircus oder O. aries } & \text { Capra hircus } \\ \text { DoT } 1477 & \text { C. hircus oder O. aries } & /\end{array}$




\subsection{Tierhaut}

\subsubsection{Pergamente}

\subsubsection{Extraktion}

Die folgenden drei Tabellen (Tab.7-9) beinhalten die Ergebnisse von Extraktionsstestreihen einer Chelexextraktion (nach Walsh et al. 1991) unter variierenden Bedingungen:

Tabelle 7: DNA-Ausbeute in Abhängigkeit von der Pergamentgröße nach 3 h Inkubationszeit (Chelex-Extraktion)

\begin{tabular}{|c|c|c|c|c|}
\hline Größe & $25 \mathrm{~mm}^{2}$ & $12,5 \mathrm{~mm}^{2}$ & ca. $6 \mathrm{~mm}^{2}$ & ca. $3 \mathrm{~mm}^{2}$ \\
\hline PA 16 & $390 \mathrm{ng} / \mu \mathrm{l}$ & $120 \mathrm{ng} / \mu \mathrm{l}$ & $100 \mathrm{ng} / \mu \mathrm{l}$ & $10 \mathrm{ng} / \mu \mathrm{l}$ \\
\hline PA 2 & / & $110 \mathrm{ng} / \mu \mathrm{l}$ & $22,5 \mathrm{ng} / \mu \mathrm{l}$ & $20 \mathrm{ng} / \mu \mathrm{l}$ \\
\hline PA 12 & $410 \mathrm{ng} / \mu \mathrm{l}$ & $190 \mathrm{ng} / \mu \mathrm{l}$ & $60 \mathrm{ng} / \mu \mathrm{l}$ & $60 \mathrm{ng} / \mu \mathrm{l}$ \\
\hline
\end{tabular}

Tabelle 8: DNA-Ausbeute in Abhängigkeit vom Volumen Chelex

\begin{tabular}{|c|c|c|c|c|c|c|}
\hline \multirow[t]{2}{*}{ Volumen } & \multicolumn{2}{|c|}{$400 \mu \mathrm{l}$} & \multicolumn{2}{|c|}{$200 \mu \mathrm{L}$} & \multicolumn{2}{|c|}{$100 \mu \mathrm{l}$} \\
\hline & Konzentr. & absolut & Konzentr. & absolut & Konzentr. & absolut \\
\hline PA 8 & $97,5 \mathrm{ng} / \mu \mathrm{l}$ & $39 \mu \mathrm{g}$ & $180 \mathrm{ng} / \mu \mathrm{l}$ & $36 \mu \mathrm{g}$ & $400 \mathrm{ng} / \mu \mathrm{l}$ & $40 \mu \mathrm{g}$ \\
\hline PA 15 & $332,5 \mathrm{ng} / \mu \mathrm{l}$ & $133 \mu \mathrm{g}$ & $630 \mathrm{ng} / \mu \mathrm{l}$ & $126 \mu \mathrm{g}$ & $1000 \mathrm{ng} / \mu \mathrm{l}$ & $100 \mu \mathrm{g}$ \\
\hline
\end{tabular}

Tabelle 9: DNA-Ausbeute von Pergamentproben unterschiedli-

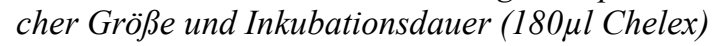

\begin{tabular}{|c|c|c|c|}
\hline & $3 \mathrm{~h}$ & $21 \mathrm{~h}$ & $\Delta$ \\
\hline PA $16-25 \mathrm{~mm}^{2}$ & $390 \mathrm{ng} / \mu \mathrm{l}$ & $430 \mathrm{ng} / \mu \mathrm{l}$ & $110 \%$ \\
\hline PA $16-12,5 \mathrm{~mm}^{2}$ & $120 \mathrm{ng} / \mu \mathrm{l}$ & $180 \mathrm{ng} / \mu \mathrm{l}$ & $150 \%$ \\
\hline PA 16 - ca. $7 \mathrm{~mm}^{2}$ & $100 \mathrm{ng} / \mu \mathrm{l}$ & $180 \mathrm{ng} / \mu \mathrm{l}$ & $180 \%$ \\
\hline PA 16 - ca. $3 \mathrm{~mm}^{2}$ & $10 \mathrm{ng} / \mu \mathrm{l}$ & $45 \mathrm{ng} / \mu \mathrm{l}$ & $450 \%$ \\
\hline PA $12-25 \mathrm{~mm}^{2}$ & $410 \mathrm{ng} / \mu \mathrm{l}$ & $900 \mathrm{ng} / \mu \mathrm{l}$ & $220 \%$ \\
\hline PA $12-12,5 \mathrm{~mm}^{2}$ & $190 \mathrm{ng} / \mu \mathrm{l}$ & $470 \mathrm{ng} / \mu \mathrm{l}$ & $247 \%$ \\
\hline PA 12 - ca. $7 \mathrm{~mm}^{2}$ & $60 \mathrm{ng} / \mu \mathrm{l}$ & $260 \mathrm{ng} / \mu \mathrm{l}$ & $433 \%$ \\
\hline PA 12 - ca. 3 mm$^{2}$ & $60 \mathrm{ng} / \mu \mathrm{l}$ & 1 & 1 \\
\hline PA $2-12,5 \mathrm{~mm}^{2}$ & $110 \mathrm{ng} / \mu \mathrm{l}$ & $150 \mathrm{ng} / \mu \mathrm{l}$ & $136 \%$ \\
\hline PA 2 - ca. $7 \mathrm{~mm}^{2}$ & $22,5 \mathrm{ng} / \mu \mathrm{l}$ & $85 \mathrm{ng} / \mu \mathrm{l}$ & $377 \%$ \\
\hline PA 2 - ca. 3 mm$^{2}$ & $20 \mathrm{ng} / \mu \mathrm{l}$ & $30 \mathrm{ng} / \mu \mathrm{l}$ & $150 \%$ \\
\hline
\end{tabular}




\subsubsection{2 mtDNA-Sequenzierung}

Abbildung 13 zeigt die 158bp lange Sequenz einer DNA, die aus einem Manuskript aus Tierhaut gewonnen wurde, auf welchem der Klosterplan von St. Gallen gezeichnet ist (850 AD). Bei der Sequenz handelt es sich um einen Abschnitt des Cytochrom B-Gens der mtDNA, wie er von dem Primersystem CB3 amplifiziert wird.

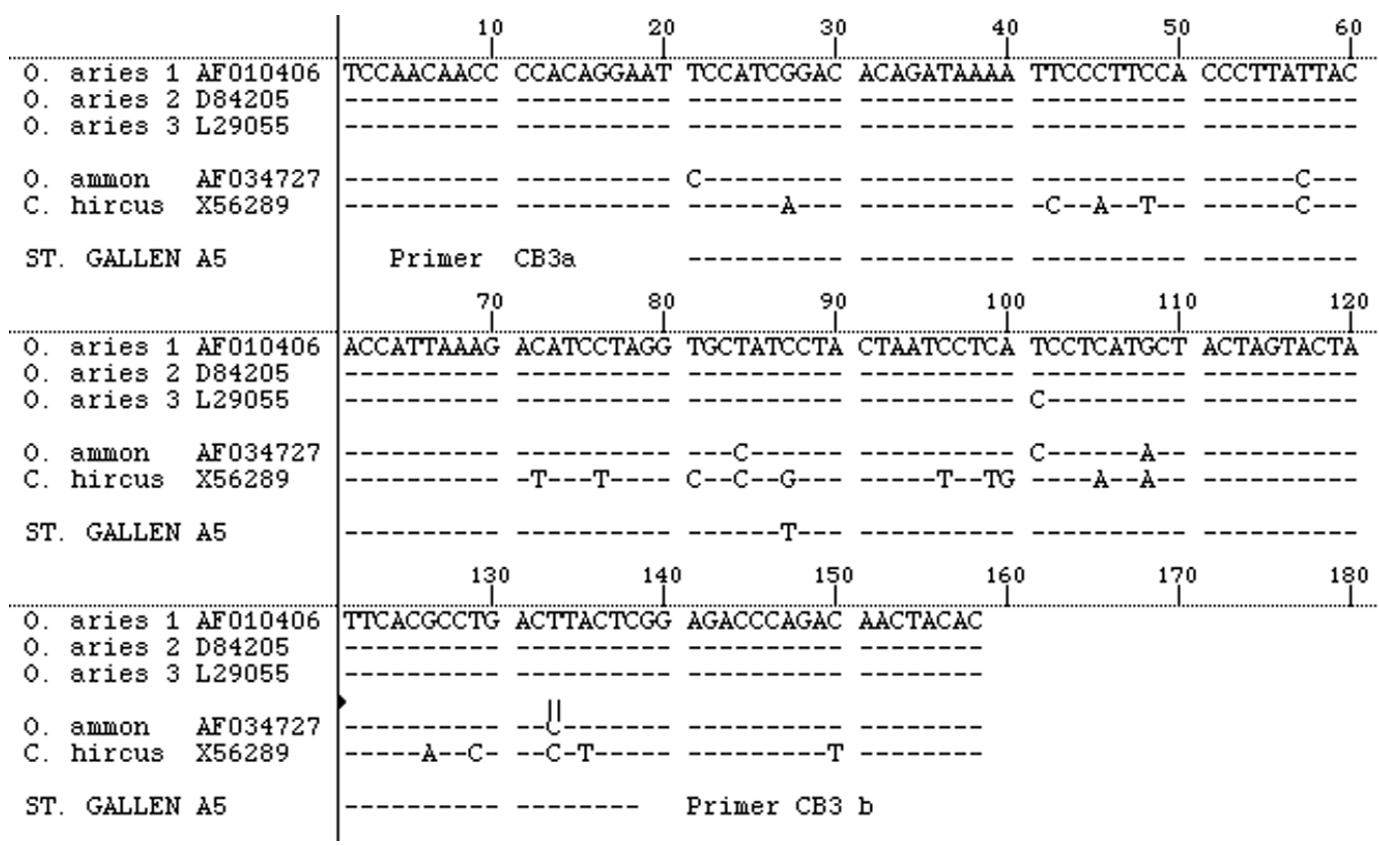

Abbildung 13. Sequenz aus dem Klosterplan von St. Gallen im Vergleich zu drei Individuen der Spezies Ovis aries (Hausschaf), und jeweils einmal Ovis ammon (Wildschaf) und Capra hircus (Ziege).

Die Sequenz wurde mit drei Schafindividuen (Ovis aries), einer Ziege (Capra hircus) und einem Wildschaf (Ovis ammon) aus GenBank verglichen. Während $O$. aries 1 und $O$. aries 2 an diesem locus identisch sind, weicht $O$. aries 3 an Position 101 der Sequenz von den O. aries 1 und 2 ab (Transition). Die aDNA-Sequenz der Probe St. Gallen A5 weicht an Position 87 von O. aries 1 und 2 ab (Transition), ist aber ansonsten identisch. Abbildung 14 zeigt diese Verhältnisse in einem Ähnlichkeitsdiagramm, welches zeigt, daß sich die Sequenz St. Gallen A5 im Rahmen der 
Variabilität von Hausschafen befindet, während das Wildschaf sich deutlich unterscheidet. Bei der Probe handelt es sich folglich um ein Pergament, das aus der Haut eines Hausschafes gefertigt wurde.

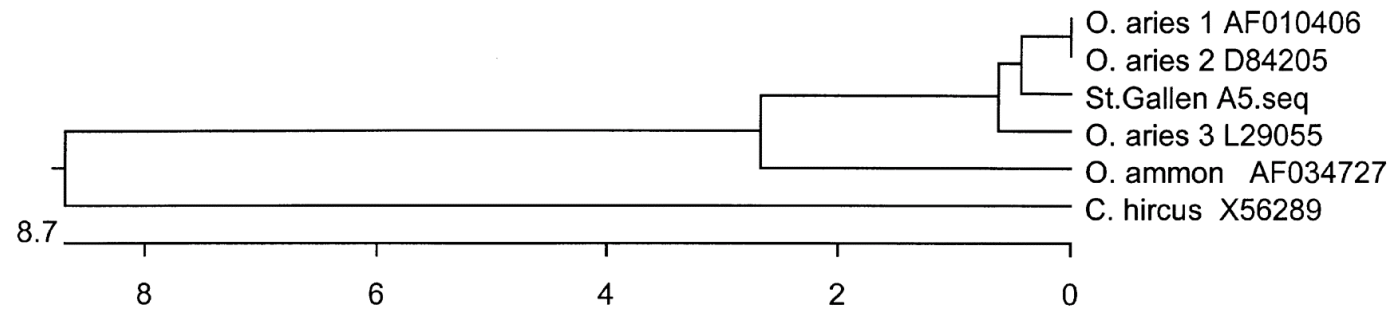

Abbildung 14: Ähnlichkeitscluster der Sequenz aus dem Klosterplan von St. Gallen und den Referenzsequenzen von Ovis aries (3x), Ovis ammon und Capra hircus

Abbildung 15 zeigt, als „Parchment“ bezeichnet, eine 56bp lange Sequenz eines Fragments der 12S rRNA-DNA (ohne Primer) aus einem $9 \mathrm{~mm}^{2}$ großen Pergamentfragment. Der Vergleich mit Referenzsequenzen von vier nahe verwandten Kaninchenspezies zeigt, daß die Probensequenz identisch ist mit derjenigen der Spezies Oryctolagus cuniculus, des europäischen Hauskaninchens. Die anderen drei Kaninchen-Spezies (Sylvilagus nuttallii, S. palustris, S. audobonii) weichen um jeweils vier Basenpaare ab. Die Sequenz wurde aus einem unabhängigen Extrakt und einer zweiten Amplifikation mit demselben Primersystem bestätigt.

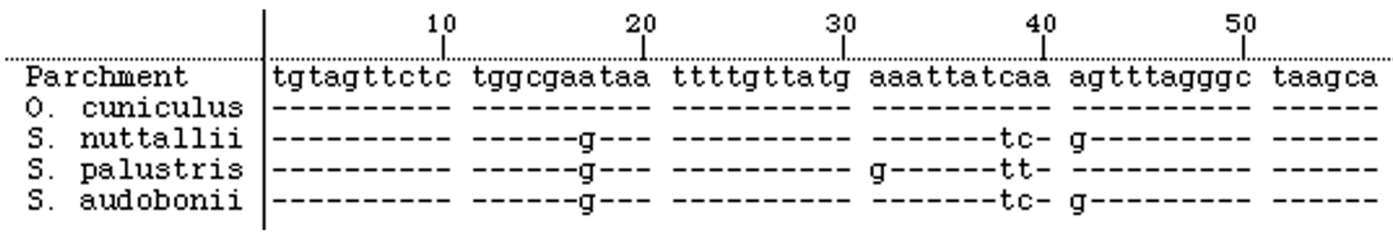

Abbildung 15: 56bp lange Sequenz aus einem Pergament im Vergleich mit Sequenzen von vier Kaninchen-Spezies

Abbildung 16 zeigt Sequenzen, die aus zwei $9 \mathrm{~mm}^{2}$ großen Fragmenten eines Pergaments gewonnen wurden. Die Sequenzen entstammen zwei unabhängigen Extrakten (Ex A, B), von denen jeweils zwei unabhängige PCR-Amplifikationen 
(PCR 1, 2, 3, 4) durchgeführt wurden. Jedes PCR-Produkt wurde sowohl forward als reverse sequenziert (seq $\mathrm{F}, \mathrm{R}$ ).

Die (ohne Primer rR4a, c) 77bp langen Sequenzen sind bis auf wenige Ausnahmen identisch. An Position 85 sind zwei von acht Sequenzen abweichend (G statt A). An Position 91 sind vier der Sequenzen unleserlich. Alle abweichenden Phänomene sind bei Cycle-Sequencing Reaktionen mit dem Primer rR4c zu beobachten. Ebenso fällt auf, daß die ersten vier bis sechs Nukleotide nach dem Primer nicht zu lesen sind. Bis auf die geschilderten Ausnahmen sind die gefundenen Sequenzen und somit auch ihre Consensus-Sequenz beim Vergleich mit Referenzsequenzen aus GenBank identisch mit der Spezies Camelus bactrianus, dem Trampeltier. Die nächst verwandten Spezies Camelus dromedarius (Dromedar) und Lama guanicoe (Lama) weichen in zwei bzw. sechs Nucleotiden von der C. bactrianus-Sequenz ab.

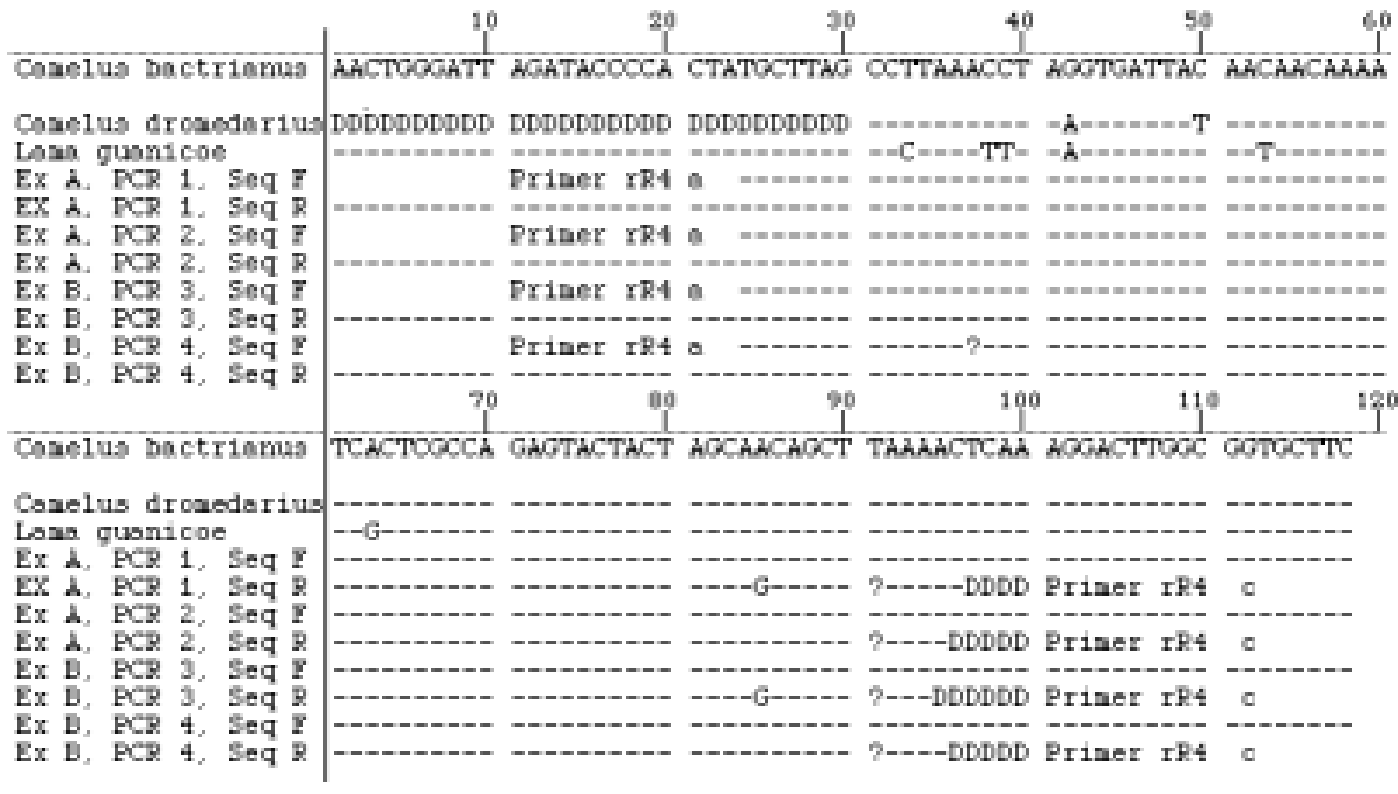

Abbildung 16: Die acht im Vergleich zu drei Kameliden-Referenzsequenzen dargestellten aDNASequenzen aus einem Pergament entstammen zwei Extraktionen und vier Amplifikationen, die jeweils forward und reverse sequenziert wurden. Von C. dromedarius war die Sequenz erst ab Position 31 in GenBank erhältlich. 


\subsubsection{STR-profiling}

Tabelle 10 zeigt die Ergebnisse der STR-Multiplex Analyse von drei historischen Pergamenten (PA 2, 13, 14). Die Alleltypisierungen, die in einem Blindverfahren aus jeweils 6 bzw. 8 Fragmenten eines Pergamentes nach insgesamt 6 unabhängigen DNA-Extraktionen gewonnen wurden, weisen unterschiedliche Qualitäten auf. Während die Allele von PA 2 und 14 fast vollständig reproduzierbar sind und in den meisten Systemen Ergebnisse zeigen, fallen die Allele bei PA 13 in den meisten Systemen aus und sind weniger reproduzierbar.

PA 2 weist in allen Systemen außer ETH225 und TGLA 122 vollständig reproduzierbare Allele auf. In den beiden genannten Systemen finden sich zum einen unsichere Allele (in Klammern), die einmal ein tatsächliches Allel darstellen (Allel 144, ETH225) und einmal ein scheinbares Artefakt, welches allerdings in zwei unabhängigen Extraktionen und PCRs reproduziert wird (Allel 155, TGLA 122). Zum andern findet sich ein Fall von Stotterbande (Allel 141, TGLA 122), die das tatsächliche Allel (143) ersetzt. Ein einziges Mal tritt ein Allel größer als 190bp auf (Allel 196, INRA 23), ansonsten gibt es keine Ergebnisse für die beiden größten Systeme INRA 23 und SPS 115. Das längste reproduzierbare Allel ist 190bp lang.

PA 14 zeigt ähnliche Muster. Die meisten Allele sind reproduzierbar, es finden sich unsichere Allele, vor allem in den längern Systemen, und ein Fall von Stotterbande, die eine Wiederholungseinheit länger ist als das tatsächliche Allel (Allel 190, BM 1824). Die Systeme über 196bp zeigen nie ein Ergebnis.

PA 13 zeigt hauptsächlich singuläre, nicht reproduzierbare Allelbestimmungen. Im System TGLA 227 lassen sich die Allele 83 und 89 aus zwei Extraktionen (C1 und C2) wiederholen. Auch die Duplex-Ergebnisse aus Extraktion C3 sind in einer PCR einmal reproduziert, allerdings nicht aus einer zweiten Reaktion. 
Tabelle 10: STR-Allelbestimmung und Genotypisierung dreier Pergamente

\begin{tabular}{|c|c|c|c|c|c|c|c|c|c|c|c|c|}
\hline & SPEZIES & $\mathbf{E X}$ & NR. & TGLA 227 & BM 2113 & ETH 225 & MTG 4B & TGLA 53 & TGLA 122 & BM 1824 & INRA 23 & SPS 115 \\
\hline & & & & (75-107 bp) & \begin{tabular}{|l}
$(125-143)$ \\
\end{tabular} & \begin{tabular}{|c|}
$(140-156$ bp $)$ \\
\end{tabular} & (132-162 bp) & (144-186 bp) & (137-183 bp) & $\mid(178-190$ bp $)$ & 196-224 bp) & $(240-262$ bp) \\
\hline \multirow[t]{6}{*}{ PA13 } & bos taurus & $*$ II & 1 & $91 /(105)$ & $135 / 139$ & $138 / 140$ & 1 & 1 & $155 / 157$ & $182 / 190$ & 1 & 1 \\
\hline & & $\mathrm{C} 2$ & 13 & $83 / 89$ & I & - & - & - & 1 & 1 & $214 / 224$ & I \\
\hline & & $\mathrm{C} 1$ & 14 & $83 / 89$ & 1 & - & - & - & 1 & 1 & - & 1 \\
\hline & & $\mathrm{C} 1$ & 19 & $83 / 89$ & 137 & - & - & - & 1 & 180 & - & 1 \\
\hline & & $\mathrm{C} 3$ & 33 & - & - & - & 148 & - & - & - & $218 / 220$ & 1 \\
\hline & & & & & & & & & & & & \\
\hline \multirow[t]{4}{*}{ PA2 } & bos taurus & $*$ & 2 & $93 / 97$ & $129 / 137$ & $(144) / 148$ & 134 & 1 & $143 /(155)$ & $182 / 190$ & 1 & I \\
\hline & & $*$ & 7 & $93 / 97$ & $129 / 137$ & $144 / 148$ & 134 & $156 / 158$ & 143 & $182 / 190$ & 196 & l \\
\hline & & *II & 3 & $93 / 97$ & $129 / 137$ & $(144) / 148$ & 134 & $156 / 158$ & $143 /(155)$ & $182 / 190$ & 1 & 1 \\
\hline & & $*$ III & 6 & $93 / 97$ & $129 / 137$ & $144 / 148$ & 134 & $156 / 158$ & 143 & $182 / 190$ & 7 & 1 \\
\hline \multirow[t]{6}{*}{ PA14 } & bos taurus & *II & 4 & $89 / 91$ & $139 / 141$ & $142 / 150$ & $134 / 144$ & $164 / 180$ & $139 / 151$ & $178 /(188)$ & 1 & 1 \\
\hline & & *II & 5 & $89 / 91$ & $139 / 141$ & $142 / 150$ & $134 / 144$ & $164 / 180$ & $139 / 151$ & $178 /(188)$ & l & 1 \\
\hline & & $*$ & 9 & $89 / 91$ & $139 / 141$ & $142 / 150$ & $134 /(144)$ & $164 /(180)$ & $139 / 151$ & $178 /(188)$ & I & 1 \\
\hline & & $*$ & 10 & $89 / 91$ & $139 / 141$ & $142 / 150$ & $134 / 144$ & $164 /(180)$ & $139 / 151$ & $178 / 190$ & l & 1 \\
\hline & & $\mathrm{C} 1$ & 15 & $89 / 91$ & $139 / 141$ & - & - & - & $139 / 151$ & $178 / 188$ & - & - \\
\hline & & $\mathrm{C} 2$ & 16 & $87 / 91$ & $139 / 141$ & - & - & - & $139 / 151$ & $178 /(188)$ & - & - \\
\hline \multicolumn{4}{|c|}{ Genotyp } & $89 / 91$ & $139 / 141$ & $142 / 150$ & $134 / 144$ & $164 / 180$ & $139 / 151$ & $178 /(188)$ & & \\
\hline
\end{tabular}




\subsubsection{Allelvergleich mit modernen Populationen}

Tabelle 11 zeigt, wie häufig Allele, die in den historischen Pergamenten PA 2 und PA 14 gefunden wurden (s. Tab. 10), in modernen Norddeutschen HolsteinFriesen Rassen vorkommen (Datenbank Institut für Tiergenetik, Göttingen). Der Vergleich ergab, daß die historischen Allele in modernen Populationen fast gar nicht $(0,005-0,03)$ oder sehr selten $(0,03-0,1)$ zu finden sind. Nur vier von 22 Allelen zeigen eine höhere Allelfrequenz als 0,1 .

Tabelle 11: Allelfrequenzen historischer Allele aus Pergamenten in modernen Populationen

\begin{tabular}{|l|l|l|l|l|}
\cline { 2 - 5 } \multicolumn{1}{c|}{} & \multicolumn{2}{c|}{ Pergament 2 } & \multicolumn{2}{c|}{ Pergament 14 } \\
\hline STR-locus & Allel (bp) & Frequenz & Allel (bp) & Frequenz* \\
\hline TGLA277 & 93 & 0,06 & 89 & 0,11 \\
\hline & 97 & 0,03 & 91 & 0,09 \\
\hline BM 2113 & 129 & 0,08 & 139 & 0,13 \\
\hline & 137 & 0,01 & 141 & 0,04 \\
\hline ETH 225 & 144 & 0,06 & 142 & 0,06 \\
\hline & 148 & 0,27 & 150 & 0,15 \\
\hline MTG 4B & 134 & 0,1 & 134 & 0,1 \\
\hline & & & 144 & 0,03 \\
\hline TGLA 53 & 156 & 0,1 & 164 & 0,03 \\
\hline & 158 & 0,09 & 180 & 0,03 \\
\hline TGLA 122 & 143 & 0,11 & 139 & 0,005 \\
\hline & & & 151 & 0,05 \\
\hline BM 1824 & 182 & 0,05 & 178 & 0,14 \\
\hline & 190 & 0,08 & $(188)$ & $(0,13)$ \\
\hline
\end{tabular}

* in einer Population moderner Holstein-Friesen Rinder (Datenbank Institut für Tiergenetik, Göttingen) 


\subsubsection{Getrocknete Haut}

Die Abbildungen 17 und 18 zeigen in je zwei Bahnen die Amplifikate einer getrockneten Tierhaut von einem ägyptischen Streitwagen (ca. 1500 v. Chr.). Die Amplifikate haben eine Länge von 158bp (CB3) bzw. 116bp (cytB). Die Extraktion der Probe erfolgte wie in 4.2.2.2.2 dargestellt. In den Bahnen rechts daneben sind zum Vergleich Amplifikate unterschiedlicher Pergamentproben aufgetragen. In allen vier Proben der getrockneten Haut sind Primerdimere, aber keine spezifischen Produkte erkennbar.

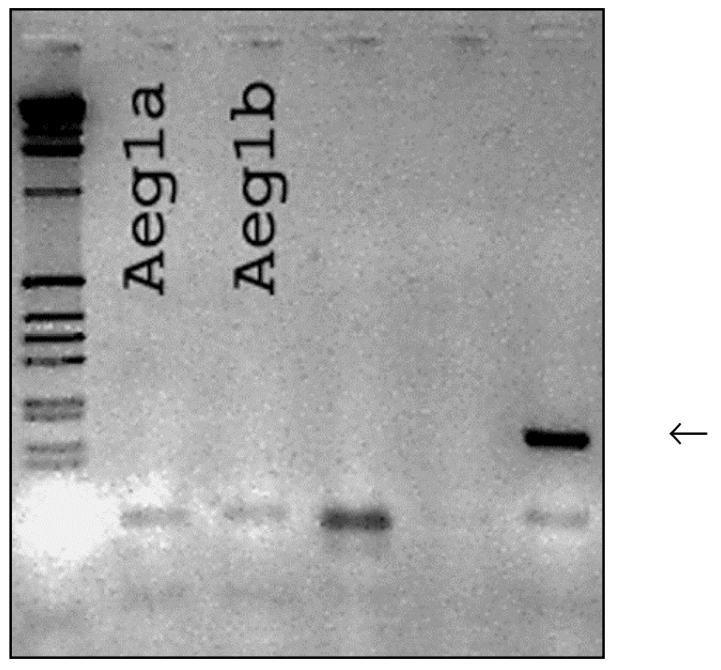

Abbildung 17: Agarosegel (negativ) von PCR-Produkten die bei der Amplifikation eines $158 \mathrm{bp}$ langen Segments des Cytochrom B-Gens mit den Primern CB3a und $b$ entstehen. Die Probe ganz rechts und der Pfeil verdeutlichen die erwartete Länge des PCR-Produkts. Bei den beiden ägyptischen Hautproben (Aegla, b) ist keine Bande im erwarteten Bereich zu sehen. Primerdimere deuten an, daß die Reaktion nicht inhibiert war.

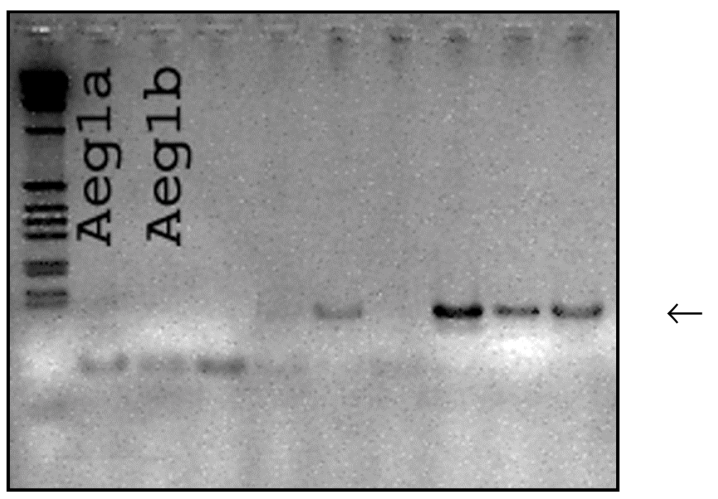

Abbildung 18: Agarosegel (negativ) von PCR-Produkten, welche bei der Amplifikation eines $116 \mathrm{bp}$ langen Segments des Cytochrom B-Gens mit den Primern Cyt a und b entstehen. Vier der sieben Proben ganz rechts und der Pfeil zeigen an, auf welcher Höhe das PCR Produkt zu erwarten ist. Die beiden ägyptischen Hautproben (Aegla, b) zeigen Primerdimere, aber kein spezifisches PCR-Produkt. 
Die Funde BD 578-95, BD 578-K und BD 2548 aus dem keltischen Salzbergwerk Dürrnberg/Bad Dürrnberg (Latène A, ca. 500 v.Chr) ergaben bei den Amplifikationen regelmäßig positive Ergebnisse, die sich aber immer als multiple Sequenzen und somit als unleserlich herausstellten (s. 6.2.2, S. 117f).

\subsection{3 (Buch-) Leder}

Spektralphotometrische Analysen von DNA-Extrakten aus rezenten ca. $10 \mathrm{~mm}^{2}$ großen Ledern ergaben nach Spezies aufgeteilt folgende Ergebnisse: Schwein: 72

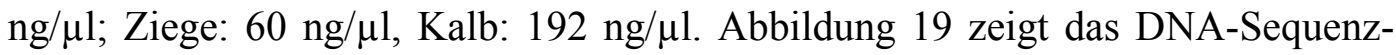
Alignment einer alten Buchlederprobe (ca. 100bp), welche morphologisch als Rinderleder bestimmt wurde. Die beiden Sequenzen stammen aus einem Extrakt und von zwei Amplifikationen. Die aDNA-Sequenzen unterscheiden sich je in einer unterschiedlichen Base von der Referenzsequenz Bos taurus. PCR- und Extraktionskontrollen waren negativ.

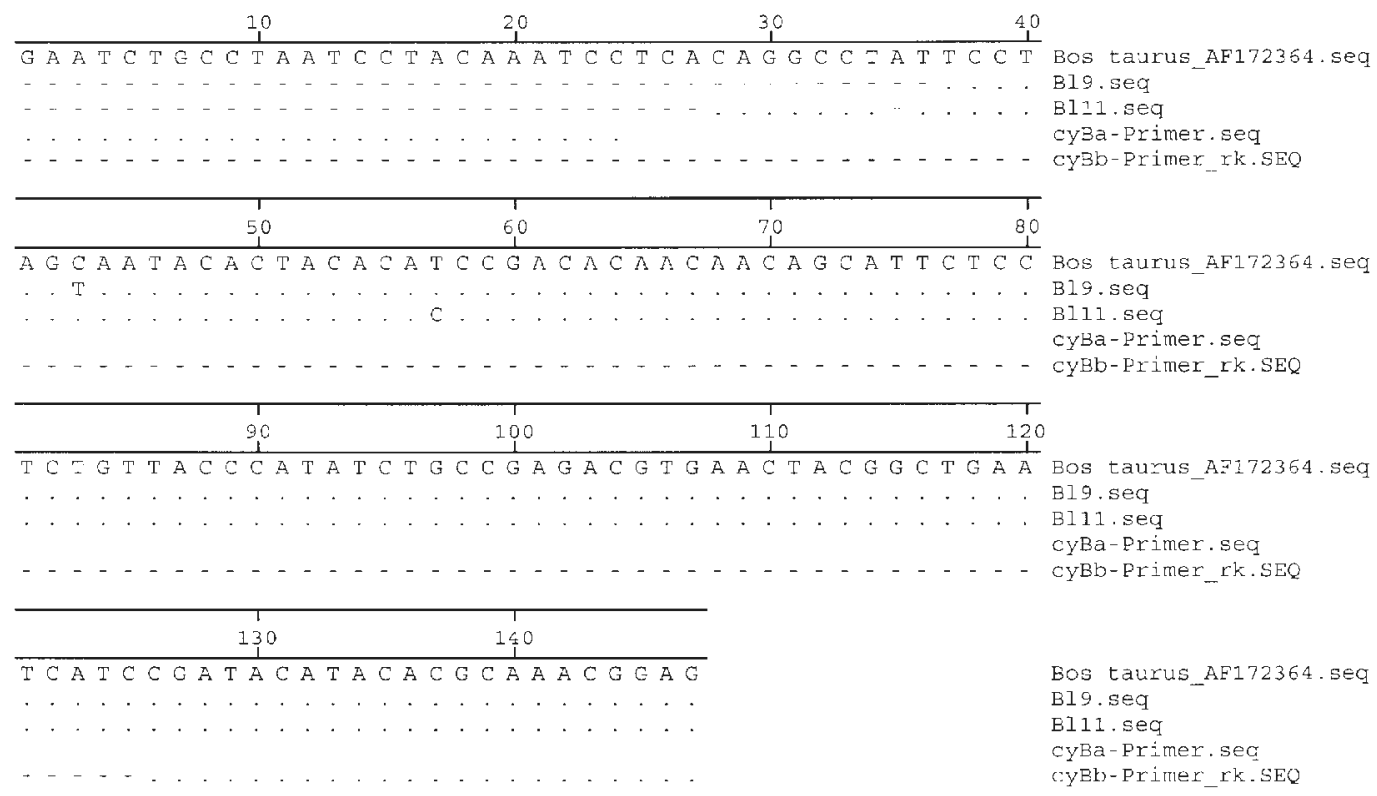

Abbildung 19: Zwei DNA-Sequenzen aus einem Buchleder im Vergleich mit der Referenzsequenz von Bos taurus. Bl9 weicht an Position 43 und Bl11 an Position 57 von der Referenzsequenz ab. 


\subsubsection{Archäologische Leder und stark gegerbte Buchleder}

Das Agarose-Gel in Abbildung 20 zeigt ein typisches Beispiel für eine PCR eines archäologischen Lederextraktes. Die Ergebnisse zweier Amplifikationen (rR4a/c) eines archäologischen Lederfundes aus der Lichtensteinhöhle (DO Le 8) ist in zwei Bahnen dargestellt. Links und rechts daneben sind Amplifikate unterschiedlicher Pergamentproben zum Vergleich aufgetragen. Die DNA-Extraktion der Lederprobe basierte auf einem $25 \mathrm{~mm}^{2}$ großen Fragment und wurde mit der QiagenMethode vorgenommen. Lederproben, die mit anderen Extraktionsmethoden, wie der Phenol/Chlorophorm-Methode, extrahiert wurden, stellen sich im Agarosebild ähnlich dar. Allen archäologischen Ledern gemeinsam ist, daß keine oder schwache Primerdimerbildung in der PCR zu beobachten ist, und selbst wenn deutlichere Primerdimere sichtbar sind (also keine vollständige Inhibition zu erwarten ist) keine spezifischen Produkte erscheinen.

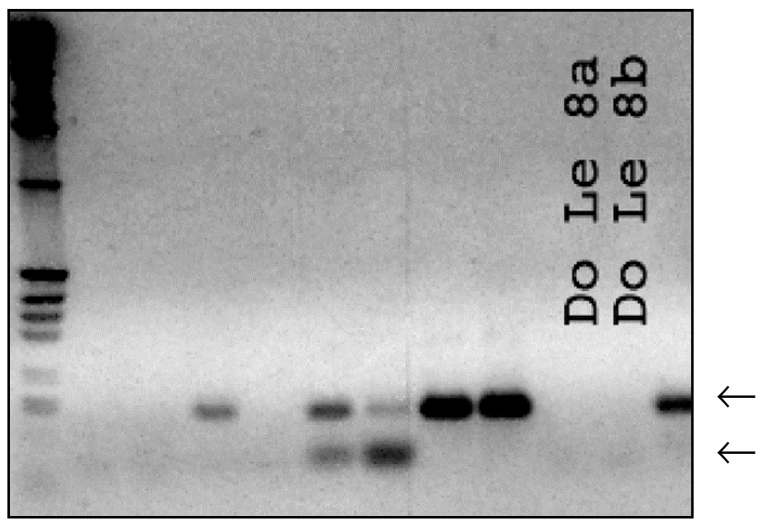

Abbildung 20: Das Agarosegelbild (negativ) zeigt zwei Amplifikationsergebnisse für den Lederfund aus der Lichtensteinhöhle (Spur 9 u. 10, DoL $8 a, b)$. Der obere Pfeil zeigt die erwartete Produktlänge (150bp), der untere die Stelle, wo sich Primerdimere befinden.

Spur 1: Längenstandard

Spur 2-6: Pergamentproben (hier zur Kontrolle)

Spur 7, 8u. 11: Positivkontrollen

Tabelle 12 zeigt die Ergebnisse der Analysen der keltischen Lederfunde von Glauburg. Keine der Proben ergab ein Amplifikations- oder Sequenzierprodukt. 
Tabelle 12: Dargestellt sind die Ergebnisse für Lederfunde des Fundorts Glauburg/Hessen (Gb). Es wird unterschieden zwischen besser erhaltenem Leder (Leder) und morphologisch stark degradiertem Leder (verg. Leder). ,,- “ und ,, + “ in der Kopfzeile stehen für PCR-Negativ- und Positivkontrollen. „PCR“ bedeutet, ob ein Amplifikationsprodukt vorhanden (+) oder nicht vorhanden (-) war. „Seq“ bezeichnet ob eine Sequenzierungsreaktion vorgenommen wurde (+) oder nicht ( $x)$.

\begin{tabular}{|l|l|l|l|l|l|l|l|l|l|l|l|l|l|}
\hline Fd.-Nr. & Art & Ort & Extrakt. & PCR 1 & - & + & PCR & Seq & PCR 2 & - & + & PCR & Seq \\
\hline Wi49 & verg. Leder & Gb & QiaAmp & rR4a,c & - & + & - & x & rR4a,c & + & + & - & x \\
\hline Wi50a & verg. Leder & Gb & QiaAmp & rR4a,c & - & + & - & x & rR4a,c & + & + & - & x \\
\hline Wi50b & verg. Leder & Gb & QiaAmp & rR4a,c & - & + & - & X & rR4a,c & + & + & - & x \\
\hline Wi50d & verg. Leder & Gb & QiaAmp & rR4a,c & - & + & - & x & rR4a,c & + & + & - & x \\
\hline Wi76/1 & verg. Leder & Gb & QiaAmp & rR4a,c & - & + & - & x & rR4a,c & + & + & - & x \\
\hline Wi76/3 & verg. Leder & Gb & QiaAmp & rR4a,c & - & + & - & x & rR4a,c & + & + & - & x \\
\hline Wi76/6 & verg. Leder & Gb & QiaAmp & rR4a,c & - & + & - & x & rR4a,c & + & + & - & x \\
\hline Wi76/8 & verg. Leder & Gb & QiaAmp & rR4a,c & - & + & - & x & rR4a,c & + & + & - & x \\
\hline Wi76/9 & verg. Leder & Gb & QiaAmp & rR4a,c & - & + & - & x & rR4a,c & + & + & - & x \\
\hline Wi91 & verg. Leder & Gb & QiaAmp & rR4a,c & - & + & - & x & rR4a,c & + & + & - & x \\
\hline Wi237 & Leder & Gb & QiaAmp & rR4a,c & - & + & - & x & rR4a,c & + & + & - & x \\
\hline Wi267 & Leder & Gb & QiaAmp & rR4a,c & - & + & - & x & rR4a,c & + & + & - & x \\
\hline
\end{tabular}

\subsection{Leime, Bindemittel und Öle}

\subsubsection{Prähistorische Felsbilder}

Abbildung 29 in Kap. 6.1.6 (S. 104f) zeigt eine rasterelektronenmikroskopische Aufnahme einer Felsbildprobe, auf der eine pflanzliche Struktur sichtbar ist, die offensichtlich nicht integrativer Bestandteil des Pigments ist.

Die folgenden Spezies zeigten eine Homologie von über 95\% mit rbcl-Sequenzen von Felsbildproben: Pinus krempfii (Coniferales, Pinaceae), Picea abies (Coniferales, Pinaceae) (2x), Picea sitchensis (Coniferales, Pinaceae), Pinus pinea (Coniferales, Pinaceae) (5x), Pinus radiata (Coniferales, Pinaceae), Brotherella recurvens (Sematophyllaceae, Brotherella). 
Pinus radiata ist in Kalifornien, Afrika, Südamerika und Großbritannien, Brotherella recurvens nur außerhalb Europas heimisch. Alle anderen Arten sind auch in Mitteleuropa anzutreffen.

Häufig waren bovine Sequenzen Ergebnis der mtDNA-Sequenzierung. In keinem Fall wich die Sequenz von modernen Bos taurus-Sequenzen ab. Desweiteren konnte aus einer Amplifikation eine feline Sequenz festgestellt werden. Diese Sequenz, die aus einer Amplifikation mit dem Primersystem Cyb entstanden ist, zeigt deutliche Nähe zur Sequenz der Hauskatze, Felis catus, (1bp Differenz) und weicht von der nächsten Panthera-Spezies in $6 \mathrm{bp}$ ab.

\subsubsection{Historische Werkstoffe}

Nachdem intensive Färbung der reinen Chelex-Extraktion aus Leimen, Bindemitteln und Ölen noch auf starke Verunreinigungen schließen ließen, wurde das erhaltene Extrakt mit dem Wizard PCR Prep ${ }^{\mathrm{TM}}$ aufgereinigt.

Tabelle 13 zeigt das Ergebnis des spektralphotometrischen Vergleichs der beiden Extraktionsmethoden. Aus der Tabelle läßt sich ersehen, daß das kommerzielle QIAamp Tissue Kit bis zu 9-fache Ausbeute an DNA im Vergleich zur kombinierten Chelex/Wizard PCR Prep ${ }^{\mathrm{TM}}$-Methode erbringt.

Tabelle 13: Vergleich zweier Extraktionsmethoden hinsichtlich der absoluten Extraktionmengen

\begin{tabular}{|l|c|l|}
\hline & \multicolumn{2}{|c|}{ DNA Menge / 0,15g Probe } \\
\hline & Chelex+Wizard PCR Prep & Qiagen \\
\hline Kasein & $3,25 \mu \mathrm{g}$ & $24 \mu \mathrm{g}$ \\
\hline Körnerhautleim & $4,5 \mu \mathrm{g}$ & $40 \mu \mathrm{g}$ \\
\hline Hasenleim & $7,4 \mu \mathrm{g}$ & $60 \mu \mathrm{g}$ \\
\hline Hausenblasenleim & $14,5 \mu \mathrm{g}$ & $\mathbf{7 0 \mu g}$ \\
\hline
\end{tabular}


Die mtDNA-Analysen der entsprechenden Proben ergaben für Kasein, Körnerhautleim und Hasenleim eindeutige Bos taurus-Sequenzen. Der vermeintliche Hausenblasenleim erwies sich der Spezies Rhodeus ocellatus zugehörig, einer Spezies aus der Superfamilie der Karpfenartigen (Cyprinoidea). Die Amplifikationen erfolgten mit dem Primersystem rR4ac.

\subsection{Inhaltsreste (prä)historischer Behälter}

\subsubsection{Die keltische Tierhaut von Dürrnberg/Österreich}

Die Abbildung 21 zeigt die mikroskopische Aufnahme der äußeren Oberfläche des Fundes BD1151-I4 aus Dürrnberg/Salzkammergut/Österreich. Entgegen der archäologischen Ansprache des Fundes als „Wurstpelle“ zeigen typische Strukturen wie Haare und Poren, daß es sich bei dem Fund um eine Tierhaut handelt und nicht um Darm wie der Terminus „Pelle“ unterstellt.

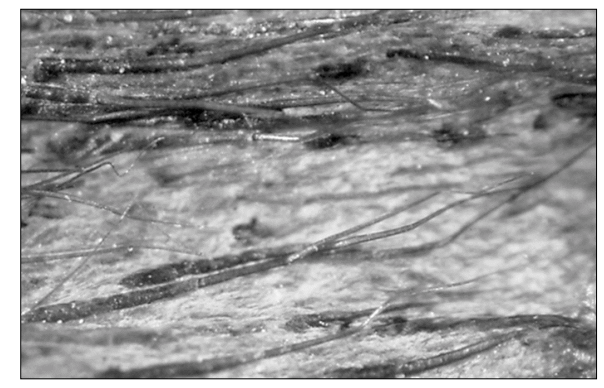

Abbildung 21: Mikroskopische Aufnahme (20-fach) der Haarseite des Fundes BD1151-I4.

- Die Haut selbst ergab keine reproduzierbaren Amplifikationsergebnisse für mtDNA (vgl. 5.2.2, S. 69).

- Die abgekratzte äußere Oberfläche ergab keine Amplifikationsergebnisse für cpDNA und mtDNA. 
- Die faserne Verschnürung ergab keine Amplifikationsergebnisse für cpDNA und mtDNA.

- Die abgekratzte innere Oberfläche samt kleiner Bröckchen in den Falten der Haut ergab eine rbcL-Sequenz. Das alignment der Sequenz der Probe erfolgte mit den drei nächst verwandten Organismen, bei denen es sich allesamt um wilde Formen von Salbei handelt (Salvia uliginosa, S. hispanica, S. divinorum, jeweils 2 Nucleotide Abweichung) und der Sequenz des heute gebräuchlichen Küchensalbeis (S. officinialis, 8 Abweichungen). Abbildung 22 zeigt die Clusterdarstellung der Sequenzen der Probe und von vier Salbeispezies basierend auf vollständig homologen Positionen. Das Ähnlichkeitsdiagramm verdeutlicht, daß die Probe mit den wilden Salvia-Spezies fast identisch ist, aber entfernter zum Küchensalbei (S. officinialis).

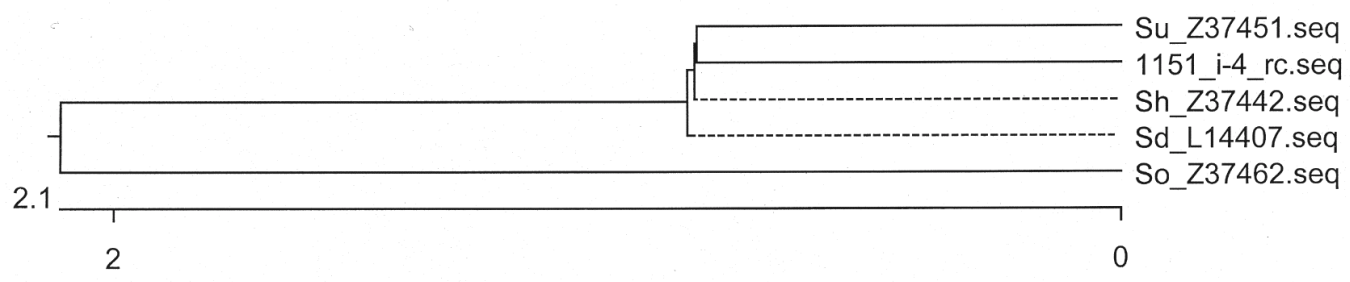

Abbildung 22: Die Probe 1151-I4 steht den wilden Formen von Salbei (Salvia uliginosa, S. hispanica, S. divinorum) näher als dem Gartensalbei (S. officinialis)

\subsubsection{Mittel- und südamerikanische Behälter des Völkerkundemuseums in Berlin}

DNA Sequenzierung der DNA aus Inkrustationen der Probe IVCa 1855, eines dreifüßigen, polychromen, tellerförmigen Gefäßes mit bis zu $1 \mathrm{~cm}$ dicken Krusten, ergab eine Sequenz, die gemäß dem Programm Blast Search (Altschul et al. 1997) größte Ähnlichkeit mit dem Genus Martinella zeigte. Innerhalb des Genus war die Spezies Martinella obovata der aDNA-Sequenz am ähnlichsten. Abbildung 23 zeigt die Probe nach dem alignment in einem Ähnlichkeitscluster mit den nächst verwandten Spezies aus GenBank. 


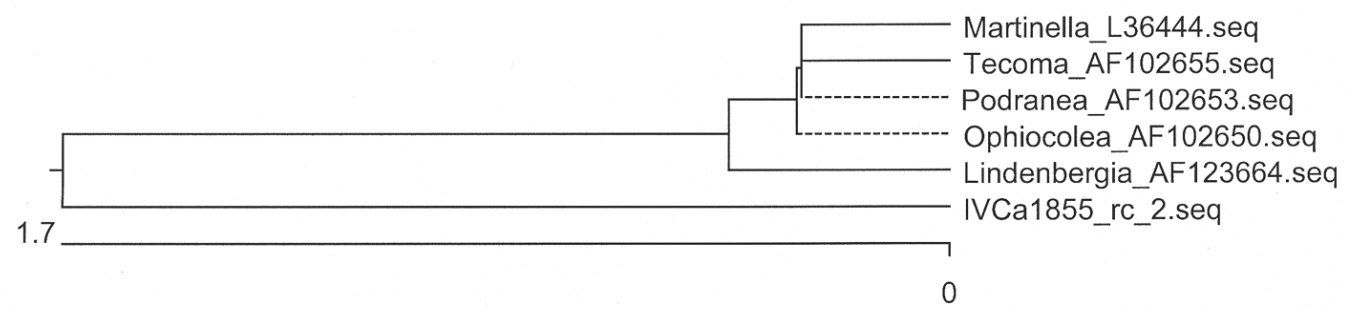

Abbildung 23: Die Probe IVCa1855 im rbcL-Sequenzvergleich zu vier Spezies der Bigoniaceae und einer Spezies der Scrophulariacea (Lindenbergia philippinensis).

Während Martinella obovata, Podranea ricasoliana, Tecoma stans, Ophiocolea floribunda zur Familie der Bigoniaceae gehören ist die Spezies Lindenbergia philippinensis Mitglied der Familie Scrophulariaceae. Abbildung 24 zeigt dasselbe Cluster mit der Sequenz von Castanea sativa (M94936, Edelkastanie) als Außenspezies. Das Cluster, das nun hervortritt, besteht aus Spezies gleicher Ordnung (Lamiales, Thorne 1992) und relativiert damit die in Abbildung 23 gezeigten Unterschiede.

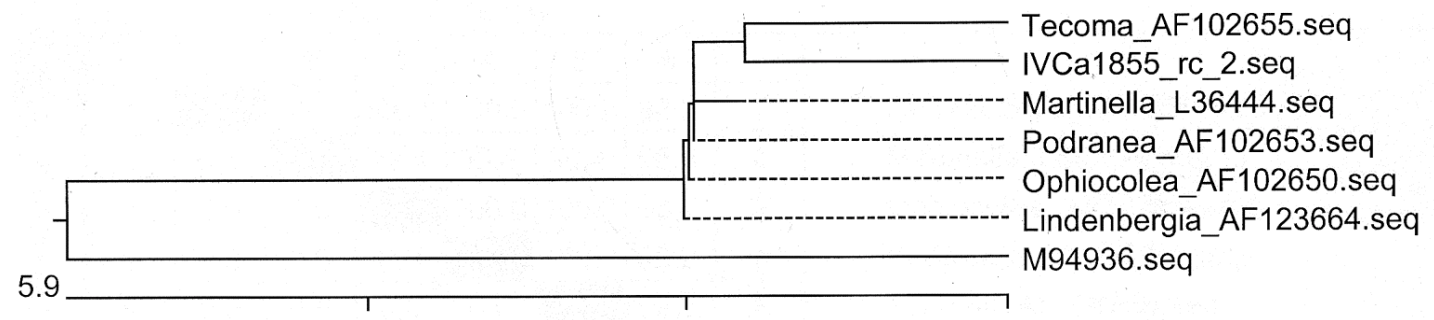

Abbildung 24: Die Probe IVCa1855 im Vergleich zu Spezies der Ordo Lamiales und der Edelkastanie (M94936) als Außenspezies.

Abbildung 25 zeigt das Sequenzcluster der Probe IVCa 1905c zusammen mit Proben, die die höchste Ähnlichkeit nach einer Blast Search Analyse gezeigt haben, und einer Edelkastanie als Außenspezies. Alle Spezies gehören zur Klasse der Li- 
liopsida (= Monocotyledoneae, d.h. einkeimblättrige Pflanzen). Die Spezies Comospermum yedoense und die beiden Hypoxidaceae Hypoxis leptocarpa und Rhodohypoxis milloides ergeben ein Cluster mit dem Konsensus-Taxon der Ordnung der Asparagales. Die restlichen Spezies Canna tuerckheimii, Heliconia latispatha und Strelitzia nicolai entstammen unterschiedlichen Familien, gehören aber alle zur Ordnung der Zingiberales, in welche sich auch die Probe aus dem Völkerkundemuseum gruppiert.

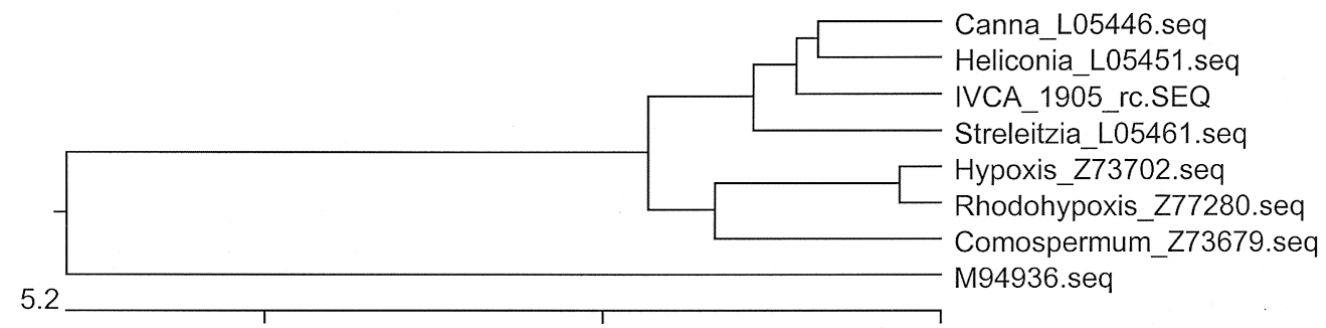

Abbildung 25: Die Probe CAIV 1905c gruppiert sich zu Referenzsequenzen der Ordnung Zingiberales.

Die Probe V8913, bestehend aus Floraresten, die aus den Ritzen eines großen Holztrogs gekratzt wurden, ergab nach Amplifikation mit dem Primer CB3 völlige Sequenzidentität zur Sequenz von Felis catus (Hauskatze).

\subsubsection{Nachgeburtsbestattungen}

Spektralphotometrische Analysen von DNA-Extrakten der vermeintlichen Plazentareste ergaben deutliche Signale bei $260 \mathrm{~nm}$ und DNA-Gehalte bis zu 490 ng/ $\mu 1$. Da die Proben nicht vom Erdreich zu trennen waren, sind bodenlebende Microorganismen als Kontributoren wahrscheinlich.

Abbildung 26 zeigt das Agarosegelbild einer Duplex PCR mit zwei humanen Microsatelliten HUMVWA31A und HUMFESFPS nach einer Qiagen-Extraktion von Resten von Nachgeburtsbestattungen. Abbildung 27 zeigt ein ähnliches Bild; in diesem Fall wurde die DNA mit einem Guanidinthiocyanat-Phenol/Chloroform- 
Methode isoliert. Auf beiden Bildern befindet sich neben der Leiter eine Positivkontrolle; die letzten drei Proben sind jeweils PCR-Negativkontrollen. Primermultimere sind bei den Proben in unterschiedlichem Maße gebildet. Während bei der Qiagen-Extraktion (Abb. 26) kaum Dimere (zweimal) entstehen, sind bei der Guanidinthiocyanat-Methode (Abb. 27) Primerdimere in 19 von 33 Fällen zu sehen, die Amplifikationen folglich weniger inhibiert. Sporadisch zeigen sich Banden im Allelbereich der verwendeten Systeme, jedoch keine Probe ergab reproduzierbare Microsatelliten-Fragmente.

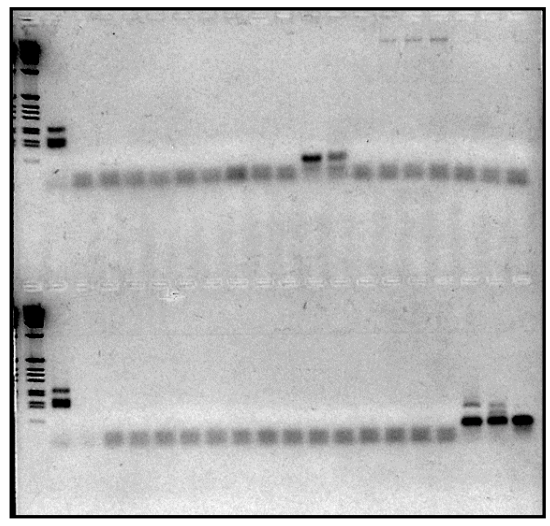

Abbildung 26: Das Agarosegelbild (negativ) zeigt die Amplifikationsergebnisse von Nachgeburtsbestattungen, die mit dem QiaAmp Tissue Kit bearbeitet worden sind.

Links befinden sich jeweils die $1 \mathrm{~kb}$-Leiter und eine Positivkontrolle. Die Amplifikationsergebnisse aller Proben sind negativ.

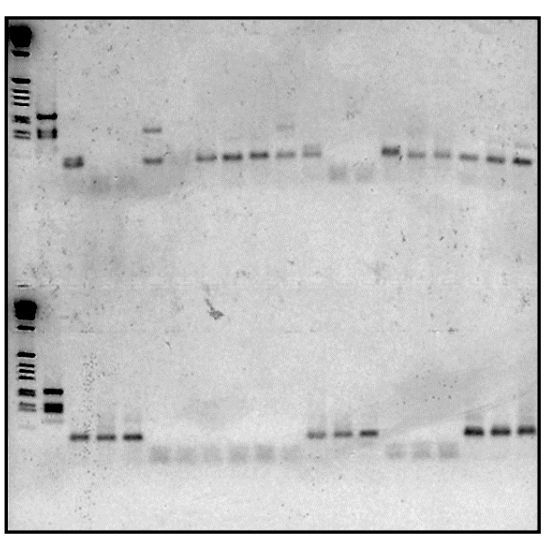

Abbildung 27: Das Agarosegelbild (negativ) zeigt die Amplifikationsergebnisse von Nachgeburtsbestattungen, die mit der Guanidinthiocyanat-Phenol/ChloroformMethode bearbeitet worden sind.

Links befinden sich jeweils die $1 \mathrm{~kb}$-Leiter und eine Positivkontrolle. Die Amplifikationsergebnisse aller Proben sind bis auf sporadische Artefakte negativ. 


\subsection{Steinwerkzeuge}

Abbildung 28 zeigt das Agarosegelbild eines Versuches, dem die Präparierung von Silexabschlägen mit rezentem Blut vorausgegangen war. Während bei St 1 und St 3 noch sichtbare Bluflecken auf dem Stein eine Woche getrocknet wurden, wurde St 2 mit einer kaum sichtbaren Menge Blutes versehen, einen Tag lang getrocknet und danach eine Woche in feuchter Humuserde vergraben. Die Proben, die mithilfe eines synthetischen „Wattestäbchens“, der mit PBS-Puffer getränkt war, vom Stein abgenommen wurden, zeigten alle die entsprechenden Banden für die Microsatellitensysteme HUMVWA31A und HUMFESFPS. Die Fragmentlängenanalyse der Microsatelliten-DNA konnte die bekannten Allele der aufgetragenen Probanden-DNA wiederidentifizieren. Eine Bande in der PCR-Leerkontrolle ergab ein Signal außerhalb des Allesbereichs von HUMVWA31A.

Die für Steinwerkzeuge etablierte Methode wurde im Rahmen der vorliegenden Arbeit nicht auf prähistorische Fundstücke angewendet. Das Thema Steinwerkzeuge wird in der Diskussion (Kap. 6.1.6, S. 104f) unter „Ungeschützte Materialien" besprochen.

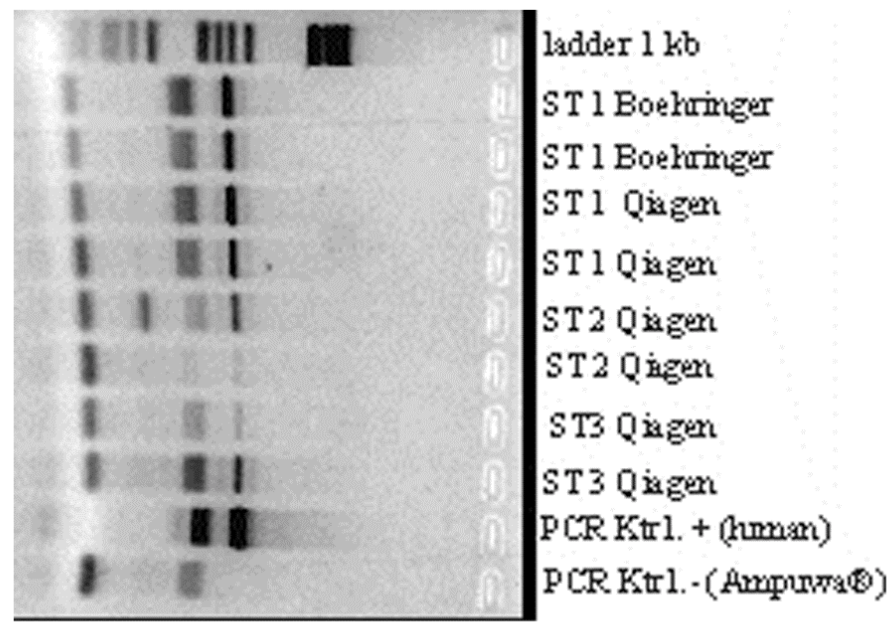

Abbildung 28: Agarosegelbild (negativ) mit STRFragmenten einer HUMVWA31AHUMFES/FPS-Duplex-Amplifikation von Blutabstrichen auf Steinwerkzeugen. 


\subsection{Archäologische Textil- und Pflanzenfunde}

In Tabelle 14 sind die Analysen an den keltischen Bast- und Textilfunden vom Fundplatz Glauberg, Wetteraukreis, dargestellt. Die einzige erfolgreiche Amplifikation (Wi 134) führte zu einer Nonsenssequenz. Alle anderen Proben zeigten weder für mtDNA nach für cpDNA positive Resultate. PCR 3 zeigte in der Leerkontrolle undeutliche Signale. PCR 4 war in der Leerkontrolle kontaminiert, was bei dem Primersystem rR4ac aufgrund seiner Primerpasstellen zu H. sapiens häufig der Fall war.

Tabelle 14: Dargestellt sind die Ergebnisse für Bast- und Textilfunde des Fundorts Glauburg/Hessen (Gb). Es wird unterschieden zwischen besser erhaltenem Leder (Leder) und morphologisch stark degradiertem Leder (verg. Leder). ,-“" und „,+ “ in der Kopfzeile stehen für PCRNegativ- und Positivkontrollen. „PCR" bedeutet, ob ein Amplifikationsprodukt vorhanden (+) oder nicht vorhanden (-) war. „Seq“ bezeichnet ob eine Sequenzierungsreaktion vorgenommen wurde (+) oder nicht (x). „Aufr." besagt, ob eine Wizard Prep Aufreinigung des ersten DNAExtrakts vorgenommen wurde.

\begin{tabular}{|l|l|l|l|l|l|l|l|l|l|l|l|l|l|}
\hline Fd.-Nr. & Art & Ort & Extrakt. & PCR 1 & - & + & PCR & Seq & PCR 2 & - & + & PCR & Seq \\
\hline Wi127 & Bast & Gb & Qia-plant & rbcL & - & + & - & - & & & & & \\
\hline Wi128 & Bast & Gb & Qia-plant & rbcL & - & + & - & - & & & & & \\
\hline Wi132 & Bast & Gb & Qia-plant & rbcL & - & + & - & - & & & & & \\
\hline Wi129 & Textil? & Gb & Chelex & rR4a,c & - & + & - & - & rbcL & - & + & - & x \\
\hline Wi130 & Textil? & Gb & Chelex & rR4a,c & - & + & - & - & rbcL & - & + & - & x \\
\hline Wi133 & Textil? & Gb & Chelex & rR4a,c & - & + & - & - & rbcL & - & + & - & x \\
\hline Wi134 & Textil? & Gb & Chelex & rR4a,c & - & + & - & - & rbcL & - & + & - & x \\
\hline
\end{tabular}

Fortsetzung:

\begin{tabular}{|l|l|l|l|l|l|l|l|l|l|l|l|}
\hline Fd.-Nr. & Aufr. & PCR 3 & - & + & PCR & Seq & PCR 4 & - & + & PCR & Seq \\
\hline Wi127 & + & rbcL & +- & + & - & - & rR4a,c & + & + & - & x \\
\hline Wi128 & + & rbcL & +- & + & - & - & rR4a,c & + & + & - & x \\
\hline Wi132 & + & rbcL & +- & + & - & - & rR4a,c & + & + & - & x \\
\hline Wi129 & + & rbcL & +- & + & - & - & rR4a,c & + & + & - & x \\
\hline Wi130 & + & rbcL & +- & + & - & - & rR4a,c & + & + & - & x \\
\hline Wi133 & + & rbcL & +- & + & - & - & rR4a,c & + & + & - & x \\
\hline Wi134 & + & rbcL & +- & + & - & - & rR4a,c & + & + & + & + \\
\hline
\end{tabular}




\subsection{PCR- und Extraktionskontrollen, Kontaminationen, Multiple Sequenzen}

\subsubsection{Tierliche DNA}

PCR-Negativkontrollen von Amplifikationen mitochondrialer DNA ergaben in 1015\% der Fälle spezifische Banden in der erwarteten Länge. Dieser Mittelwert variiert zwischen den verwendeten PCR-Systemen, zwischen den Herstellern der Reaktionsgefäße und zeitlich beträchtlich. Wenn die PCR-Produkte sequenziert wurden, ergaben sie in fast allen Fällen Sequenzen der Spezies Bos taurus, Homo sapiens oder unleserliche Sequenzen - seltener Sus scrofa oder Ovis aries. Unleserliche Sequenzen waren entweder multiple Sequenzen oder Nonsens-Sequenzen. Gerade diejenigen Proben, die nie zu einem eindeutigen Sequenzergebniss führten, aber dennoch häufig PCR-Produkte im Agarosegelbild aufwiesen, lieferten meistens multiple Sequenzen, also das Produkt unterschiedlicher Organismen bzw. Moleküle.

Extraktionskontrollen zeigten in 30\% aller Fälle positive Resultate im Agarosegelbild. Auch hier ergaben sich die bereits genannten Spezies durch die Sequenzanalyse. Dieselben Phänomene waren in wenig geringerem Umfang auch in Amplifikationen von Probenextrakten zu beobachten, und zwar gerade in denjenigen Proben, die ansonsten keine positiven Resultate lieferten.

Probenkontaminationen durch menschliche Bearbeiter sind bei der Suche nach tierlichen Organismen leicht zu erkennen und auszuschließen, vorausgesetzt sie treten nicht additiv auf und führen $\mathrm{zu}$ multiplen Sequenzen (vgl. Handt et al. 1996). Im folgenden Fall, bei dem menschliche DNA selbst Untersuchungsgegenstand sein sollte, wurden humane Microsatelliten-Polymorphismen hinzugezogen, um eventuelle Kontaminationen aufzudecken.

Von einem aztekischen Manuskript, das sich im Berliner Museum für Völkerkunde befindet, wurde angenommen, daß es möglicherweise aus Menschenhaut gefertigt sei. Die DNA-Sequenzierungen mitochondrialer DNA (Primersysteme CyB und Cyt), die aus einer Hälfte eines $12 \mathrm{~mm}^{2}$ großen Fragments des Mansukripts gewonnen wurde, ergaben zweimal eine menschliche Sequenz. Daraufhin wurde 
das verbleibende Fragment in zwei Proben geteilt, diese unabhängig voneinander extrahiert und aus beiden Extrakten je zwei STR-Amplifikationen mit dem AmpFl STR ProfilerPlus ${ }^{\mathrm{TM}}$ (PE Biosystems) vorgenommen. Die einzelnen Alleltypisierungen für alle vier Amplifikationen und die daraus resultierende Genotypisierung des Fundstücks sind in Tabelle 15 dargestellt.

Um das Ergebnis zu überprüfen, wurden von den Bearbeiterinnen (Amelogenin = $\mathrm{X})$ der letzten Jahre Blutproben genommen, Genotypisierungen vorgenommen und diese mit dem gefundenen Resultat aus dem Berliner Manuskript verglichen. In der Tabelle ist die Probe einer Bearbeiterin dargestellt, auf die der Genotyp der Probe zurückgeführt werden kann. Die Bearbeiterin hat das Manuskript etwa sechs Wochen vor der Analyse in den Händen gehabt und dabei kontaminiert. Inzwischen hat sich durch rasterelektronenmikroskopische Analyse ergeben, daß das Manuskript pflanzlichen Ursprungs ist und aus dem Bast eines Feigenbaums hergestellt wurde (J. Wouters, pers. Mitteilung).

Tabelle 15: STR-Allelbestimmungen der Probe PA B aus zwei Extraktionen (I, II) und vier Amplifikationen (a-d) mit Konsensus-Genotypisierung und Vergleich mit dem Genotyp eines Bearbeiters.

\begin{tabular}{|c|c|c|c|c|c|c|c|c|c|c|c|}
\hline Extr. & Probe & $\mathbf{X} / \mathbf{Y}$ & $\begin{array}{c}\text { D35 } \\
1358 \\
\end{array}$ & VWA & FGA & $\begin{array}{c}\text { D8 } \\
\text { S179 }\end{array}$ & $\begin{array}{l}\text { D21 } \\
\text { S11 } \\
\end{array}$ & $\begin{array}{l}\text { D18 } \\
\text { S51 } \\
\end{array}$ & $\begin{array}{c}\text { D5 } \\
\text { S818 }\end{array}$ & $\begin{array}{c}\text { D13 } \\
\text { S317 }\end{array}$ & $\begin{array}{c}\text { D7 } \\
\text { S820 } \\
\end{array}$ \\
\hline I & PA B a & $\mathrm{X}$ & $16 / 18$ & I & 22 & 13 & 36 & $16 / 17$ & 11 & $8 /(15)$ & I \\
\hline I & PA B b & I & I & I & 1 & 13 & 1 & I & 1 & I & I \\
\hline II & PA B c & $X$ & 16 & I & 22 & 13 & $27 / 28$ & $(15) / 16$ & $(8) / 9 / 11$ & $8 / 11 / 12$ & 10 \\
\hline II & PA B d & $\mathrm{X}$ & 16 & $16 / 17$ & 22 & 13 & $28 / 29$ & 16 & $9 / 11 / 12$ & 8 & 1 \\
\hline \multicolumn{2}{|c|}{ Genotyp } & $\mathbf{X}$ & 16 & I & 22 & 13 & I & $16 /-$ & 11 & 8/- & I \\
\hline III & Bearb. & $\mathbf{X}$ & 16 & $16 / 17$ & 22 & 13 & $28 / 29$ & $12 / 16$ & 11 & 8 & $10 / 12$ \\
\hline
\end{tabular}




\subsubsection{Pflanzliche DNA}

PCR-Amplifikationskontrollen und Extraktionskontrollen von Chloroplast-DNAReaktionen ergaben in 50-60\% der Fälle positive Resultate. Dieser Mittelwert schwankte saisonbedingt stark. Unter den Sequenzen, die nach Blast Search die höchste Ähnlichkeit aufwiesen, befanden sich Picea abies (Coniferales, Pinaceae) (Fichte), Picea sitchensis (Coniferales, Pinaceae) („Sitka spruce“), Pinus pinea (Coniferales, Pinaceae) (Kiefer) und Avena sative (Poaceae, Avena) (Hafer). 


\section{Diskussion}

\subsection{Materialanalysen}

\subsection{1 Überblick}

In 6.1.2 werden unter dem Titel „Kollagenhaltigen Materialien“ Knochen und Produkte aus Tierhaut aufgrund ähnlicher Ergebnisse zusammengefasst. Dabei werden die Ergebnisse an Knochen nur noch in Hinsicht auf die Methode des PCR-RFLP diskutiert, da sie als Material selbst nicht Gegenstand intensiver Betrachtung sein sollen. Dasselbe gilt für die forensische Probe (IP1), die exemplarisch für das Thema „Speziesidentifikation von gemischten Spuren“ stehen soll.

In 6.1.3 werden unter „Leime, Bindemittel und Öle“ historische Werkstoffe sowie Prähistorische Felsbilder abgehandelt; die letzteren erscheinen unter anderem As-

pekt auch in Kapitel 6.1.6 (S. 104ff) unter „Ungeschützte Materialien“, in dem auch auf die Steinwerkzeuge eingegangen wird.

In Kapitel 6.1.4 werden unter „Inhaltsreste (prä)historischer Behälter“ nicht nur die Ergebnisse der völkerkundlichen Behälter und der Nachgeburtsbestattungen, sondern auch die sogenannte „Wurstpelle“ von Dürrnberg diskutiert. Letztere erscheint hier und nicht unter „Getrocknete Haut“, da nicht sie selbst, sondern ihr Inhalt ein Ergebnis erbracht hatte.

In Kapitel 6.1.5 werden unter dem Titel „Archäologische Kleinfunde“ nicht nur Textil- und Pflanzenfunde, sondern auch archäologische Lederfunde abgehandelt. 


\subsubsection{Kollagenhaltige Materialien}

Das Hydroxylapatit des Knochens bietet wie kaum eine andere Matrix DNAMolekülen Schutz vor chemischen und physikalischen Schäden (Lassen et al. 1994, Burger et al. 1999a). Welche interagierende Rolle dabei Proteine allgemein und Kollagen im besonderen spielen, ist kaum erörtert. Lediglich auf analytischer Ebene wird das Phänomen diskutiert, ob Korrelationen zwischen dem Verfall von Proteinen, genauer der Enantiomerisierung v.a. von Asparaginsäure (Asp), und dem von DNA bestehen (Bada et al. 1994, Poinar et al. 1996, Bada et al. 1999, Poinar \& Stankiewicz 1999). Dem liegt die Ammahme zugrunde, daß die Rate von DNA-Depurinierungen den gleichen Ursachen unterworfen ist, wie die Rate der Isomerisierung von Aminosäuren (Asp, Val, Ala). Collins et al. (1999) weißen indessen nach, daß es sich hierbei nur um eine sehr schwache Korrelation handelt, v.a. weil freie Aminosäuren in vitro sich anders verhalten als in Peptiden gebundene Aminogruppen.

Bada et al. 1999 stellen die Theorie auf, daß die Zucker apurinischer Stellen der DNA mit freien Aminosäuren Maillard-Reaktionen eingehen können und dabei Teil von Polymeren werden, die Huminsäuren ähnliche Eigenschaften aufweisen und vor hydrolytischen Schäden geschützt sind (vgl. Poinar et al. 1998). Insofern könnte sich die Anwesenheit von Proteinen im Gewebe positiv auf den DNAErhalt auswirken. Letztlich handelt es sich hierbei um ein Modell und es gilt zu prüfen, ob nicht etwa andere Komponenten, wie etwa die schützenden Eigenschaften der mineralischen Matrix im Falle von Knochen oder der spezielle Herstellungsprozess bei Pergamenten den wesentlichen Einfluß auf den DNA-Erhalt haben.

\subsubsection{Knochen (PCR-RFLP)}

Knochen sind bereits Gegenstand zahlreicher Untersuchungen und sollen hier nur zur Exemplifizierung der Methode der Speziesidentifizierung mittels PCR-RFLP herangezogen werden. Am Material der bronzezeitlichen Tierknochen aus der 
Lichtensteinhöhle konnte gezeigt werden, daß Restriktionspolymorphismen auf dem Cytochrom B-locus geeignet sind, um hypothesengeleitet Tierspezies zu identifizieren. Die konkrete Fragestellung stammte in diesem Fall aus der Archäozoologie. Während bei den meisten Skelettelementen Ziege und Schaf morphologisch differenzierbar sind, ist dies vor allem bei stark fragmentierten Funden und bei gewissen Skelettelementen (z.B. mandibula) nicht mehr möglich (Schoon, pers. Mitteilung). Der PCR-RFLP eines 195bp langen Segments (CB7) konnte von zehn untersuchten Individuen acht mit der Endonuclease TSP509 im ersten Versuch identifizieren. Alle morphologisch als Schafe bestimmten Individuen erwiesen sich auch durch die genetische Analyse als Schafe. Gleiches gilt für die Ziegen. Ein morphologisch nicht zu identifizierendes Individuum konnte als Ziege identifiziert werden. Darüber hinaus konnte die morphologische Identifizierung eines Rinderknochens genetisch bestätigt werden. Der locus CB7 beinhaltet neben Restriktionspolymorphismen des Enzyms TSP509 für Ziege, Schaf und Rind auch solche für Reh und Hirsch. Aus den beiden Agarosegelbildern in Abbildungen 11 und 12 (S.) wird deutlich, daß alle genannten Spezies auch ohne Wissen um die Fragmentlängen allein durch Vergleich mit Rezentkontrollen zu unterscheiden sind. Die PCR-RFLP Methode, die bereits Anwendung in der Lebensmittelanalytik findet (z.B. Plath et al. 1997: 253bp, Unterscheidung zwischen Milchprodukten bovinen und ovicaprinen Ursprungs; Meyer et al. 1995: 359bp, Unterscheidung von bis zu vier Spezies aus Fleischprodukten), bietet somit eine kosten- und aufwandsgünstige Alternative für die DNA-Sequenzierung phylogenetisch bekannter Organismen (z.B. Burger et al. 1998, Bartlett \& Davidson 1992).

Von der forensischen Probe IP1 liegen PCR-RFLP -Ergebnisse aus drei Extraktionen (EX A, B, C; vgl. Abb. 12. S. 58ff), Amplifikationen und Enzymbehandlungen vor. Alle drei zeigen das gleiche Resultat. Zum einen konnte positiv gezeigt werden, daß es sich weder um Hirsch noch um Reh handelt, wie die Hypothese für die Probe besagt hatte. Zum anderen handelt es sich mit Sicherheit um zwei unterschiedliche Organismen, da die Gesamtsumme der Basenlänge ihrer Fragmente die des Ausgangsprodukt übersteigt und bei mindestens 350bp liegt. Die Bandenstruktur legt die Vermutung nahe, daß es sich bei der Probe um ein Gemisch aus Schaf und Rind handelt. Diese Aussage wird auch durch das Ergebnis mit dem Enzym 
NdeII (Abb. 10, S. 58f) gestützt. Hier besitzt die Probe IP1 dieselbe Schnittstelle wie Rind und Schaf. Die Hypothese, daß es sich bei der gelegten Spur für die Wildjagd mit Jagdhunden um Hirschblut handelte, kann folglich eindeutig widerlegt werden. Stattdessen handelt es sich bei der Probe mit an Sicherheit grenzender Wahrscheinlichkeit um eine Mischung aus Schafs- und Rinderblut. Diese Aussage wird gestützt durch externe Ergebnisse, die sowohl mtDNA-Sequenzen vom Schaf als auch Microsatelliten-DNA vom Rind nachweisen konnten (I. Pfeiffer pers. Mitteilung). Die Anwendung der PCR-RFLP Methode macht in diesem Fall einen Vorteil deutlich, den sie gegenüber der direkten Sequenzierung hat. Die direkte Sequenzierung eines DNA-Gemisches würde in der Regel zu einer multiplen und unleserlichen Sequenz führen. Der PCR-RFLP löst die Überlagerung der Signale in Fragmente unterschiedlicher Länge auf und kann somit eine Alternative zur aufwendigen Sequenzierung von klonierten PCR-Produkten werden.

Es gilt bei der Interpretation von RFLP-Bandenmustern zu bedenken, daß eine unerwartete Spezies zufällig mit einer bekannten, erwarteten übereinstimmen und verwechselt werden könnte. Um diesen, für die meisten Anwendungen eher unwahrscheinlichen Vorgang zu verhindern, bedarf es bei der RFLP-Analyse, wie schon erwähnt, sinnvoller Hypothesen. Für ansatzfreies screening ist die Methode nicht geeignet.

Kontaminationen der Reaktion durch menschliche DNA konnten bei dem speziell für den PCR-RFLP etablierten System CB7 durch gezieltes Primerdesign ausgeschlossen werden (s. Abb. 9, S. 58). Die Möglichkeit, mehrere Enzyme zu kombinieren und somit Schnittstellenpolymorphismen anzureichern, wie es mit dem Duplex-Ansatz von NdeII und DdeI exemplarisch an alten Knochen gelungen ist, ermöglicht die Erweiterung des Anwendungsspektrums auf eine größere Anzahl von Spezies. Mit einer Amplikonlänge von 195bp sind der weiteren Addition von Restriktionsendonucleasen jedoch physikalische Grenzen gesetzt. Dennoch scheint es in Anbetracht der großen Anzahl unterschiedlicher Restriktionsenzyme bei Wahl des geeigneten mitochondrialen locus möglich, fast jede beliebige Fragestellung der Speziesidentifizierung mit dem PCR-RFLP zu lösen. Durch die Verkürzung der Produktlänge auf 195bp konnte damit zum ersten Mal ein relativ schnel- 
ler und praktikabler Zugang zur mengenmäßigen Auswertung archäozoologischer Fragestellungen mit molekulargenetischen Methoden gewonnen werden.

\subsubsection{Pergamente}

Inzwischen liegen zahlreich Veröffentlichungen zum Thema alte DNA aus Tierknochen vor (z.B. Loreille et al. 1997, Bailey et al. 1996, Hardy et al. 1994), während es über DNA aus historischen Pergamenten nur einen Konferenzbeitrag und einen vorläufigen Bericht im Zusammenhang mit der Bearbeitung der QumranRollen vom Toten Meer gibt (Kahila Bar-Gal 1995, Woodward et al. 1996). Dabei zeigen die Ergebnisse der vorliegenden Untersuchung, daß Pergament zu den Materialien gehört, die in den Erfolgsaussichten, alte DNA aus ihnen zu isolieren, an die guten Erfahrungen mit Knochen anschließen können.

\subsection{Herstellung, Lagerung und DNA-Erhalt}

Ursache für die guten Erhaltungsaussichten alter DNA in Pergamenten ist die Herstellungs- und Lagerungsart der Mehrzahl der Pergamente. Das mechanische Entfernen der Haut- und Fleischseite und das schnelle Trocknen der Haut in gespanntem Zustand verringert das Ausmaß autolytischen und mikroorganismischen Schadens an der DNA. Um die Haare und Fleischreste zu entfernen wurden Pergamente meist in 5-10\% Kalklauge (im Sommer drei im Winter sechs Wochen) eingelegt. Die Kalklauge wird hergestellt, indem Kalkstein $\left(\mathrm{CaCo}_{3}\right) \mathrm{zu}$ Calciumoxid $(\mathrm{CaO})$ verbrannt wird und durch Ablöschen mit Wasser Calciumhydroxid $\left(\mathrm{Ca}(\mathrm{OH})_{2}\right)$ entsteht (Fuchs 1991). Die Wirkung der stark alkalischen Kalklauge, die regelhafter Bestandteil historischer Pergamentherstellung in Europa war (Heidemann 1991), auf die DNA dürfte ambivalent sein. Zum einen führt sie zur hydrolytischen Spaltung der DNA, zum anderen stoppt sie die Autolyse, verringert oxidative Schäden und minimiert Befall durch Mikroorganismen auch nachträg- 
lich. Pergamente werden im Gegensatz zu Ledern nach der Lauge meistens nicht entkalkt. Der in der sogenannten „Blöße“ verbliebene Kalk wandelt sich an der Luft in Karbonat um (Heidemann 1991). Möglicherweise bindet das Kalziumkarbonat DNA und schützt sie somit vor Degradierung; hierbei handelte es sich vermutlich um eine ähnliche Schutzfunktion, wie sie das Bioapatit für die DNA im Knochen übernimmt (Eglinton \& Logan 1991, Eglinton 1997). Durch die Entstehung von Kalziumkarbonat aus Kalk würde der pH-Wert in der Haut sich von extrem alkalisch zu leicht alkalisch verschieben. Letztendlich würde die Haut ohne zusätzliche Einflüsse ihre Alkalität nie ganz verlieren. Bisher ist durch Untersuchungen an Knochen vor allem die negative Wirkung eines sauren pH-Werts auf das Mineral und die DNA bekannt (Burger et al. 1999a). Von einem neutralen bis leicht alkalischen pH-Wert kann angenommen werden, daß er dem DNA-Erhalt eher förderlich ist.

Möglicherweise sind es gerade diejenigen Pergamente, die zu lange in der Lauge lagen oder zu warm getrocknet wurden, die auch keine DNA aufweisen. Systematische Erkenntnisse hierzu sind aufgrund der unbekannten Herkunft und Fertigungsart der für diese Untersuchung vorliegenden Proben noch nicht zu gewinnen gewesen, wären aber für weitere Arbeiten von großem Interesse. Einen weiteren Vorteil für die DNA bietet die Lagerungsart von Pergamenten. Da Pergamente Wasser schnell und in großen Mengen aufzunehmen in der Lage sind (Reed 1972), wurden sie in der Regel vor Feuchtigkeit geschützt, um das Material und seinen Inhalt vor Zerstörungen zu bewahren. Aufgrund seiner großen Oberfläche ist Pergament allerdings auch stark durch freie Radikale gefährdet, die sich unter Licht und Wärme im Kollagen bilden können (Rasmussen et al. 1999). In den Bibliotheken der modernen Innenstädte werden freie Radikale darüber hinaus unter Einfluß von $\mathrm{SO}_{2}$ und Hitze produziert. Dies führt zu oxidativen Schäden der kollagenen Matrix (Rasmussen et al. 1999), sowie der DNA des Pergaments. $\mathrm{NO}_{2}$ Verschmutzung resultiert zwar nicht in der Bildung freier Radikale, führt aber zu hydrolytischen Schäden. Handelt es sich bei einer Probe um ein Buch, so ist diese Überlegung von Wert für die Probenentnahme, da die DNA am Schnitt (Buchblock) und am Außensteg der Seite des Buches eher oxidativen und hydrolytischen Umweltbeeinflussungen unterzogen ist (vgl. Schmidt \& Schram 1998). Auf der 
beschriebenen Seite selbst ist mit den Einflüssen von Tinte und Pigmenten zu rechnen. Zum einen können die metallhaltigen, toxischen historischen Tinten (z.B. $\mathrm{Pb}_{3} \mathrm{O}_{4}$ oder $\left.\mathrm{Cu}\left(\mathrm{CH}_{3} \mathrm{COO}\right)_{2} \cdot 2 \mathrm{H}_{2} \mathrm{O}\right)$ vor mikroorganismischer Degradierung schützen, zum anderen führen sie zu starken oxidativen Schäden, die in der Lage sind, nicht nur die DNA, sondern das ganze Material zu zerstören. Die Lagerungstemperatur von Pergamenten ist in den meisten Fällen keinen extremen Schwankungen über die jahreszeitlichen Innenraumwechsel hinaus unterworfen. Die mittelalterlichen und neuzeitlichen Skriptorien und Bibliotheken waren nur selten beheizt, so daß die Manuskripte zwar vermehrt Wasser aus der umgebenden Luft ziehen konnten, aber auch weniger hohen Temperaturen ausgesetzt waren. Dem Faktor Temperatur wird allgemein eine wesentliche Rolle für den Erhalt der DNA beigemessen (z.B. Lindahl 1993, Höss et al. 1996, Burger et al. 1997, Burger et al. 1999a). Zwei weitere Fundstücke, die im Rahmen der vorliegenden Arbeit untersucht wurden, sollen stellvertretend für das „Für und Wider“ in der Diskussion um den Einfluß der Temperatur bei Degradierungsprozessen von Biomolekülen (s. z.B. Collins et al. 1999) stehen. ${ }^{5}$ Die getrocknete Haut von einem ägyptischen Streitwagen, die einem warmen Klima entstammt, mag ein Beleg für den dominierenden Einfluß der Temperatur auf den DNA-Erhalt sein. Obwohl sie morphologisch in einwandfreiem Zustand war und große Mengen an Material der Analyse zugeführt werden konnten, wies sie keine endogene DNA auf. Insofern ist es wiederum überraschend, daß der prähistorische texanische Fußknochen, der als Trughirsch identifiziert wurde (vgl. 5.1.1, S. 57), eindeutige und reproduzierbare DNASequenzen aufwies, obwohl er über Jahrhunderte in einem warmen Steppenklima gelagert war. Dies kann im Widerspruch zu den Aussagen über den dominierenden Einfluß der Temperatur als Beleg dafür gewertet werden, daß schnelles Austrocknen eine wesentliche Rolle spielt und DNA auch vor hohen Temperaturen schützen kann. Insofern wäre es auch zu erklären, wie es dazu kommen kann, daß aus vielen Pergamenten, obwohl der Trocknungsvorgang sicherlich unter der Sonne oder in der Nähe einer Heizquelle stattgefunden hat, ausgesprochen deutliche mi-

\footnotetext{
${ }^{5}$ Zugleich wird hierdurch deutlich werden, daß die Suche nach Ursachen für den Erhalt oder NichtErhalt von alten Molekülen spekulativ bleiben wird, solange nicht mehr systematische Untersuchungsreihen zum DNA-Erhalt in Abhängigkeit von der Erhaltungshistorie von Fundstücken bekannt sind.
} 
tochondriale DNA-Sequenzen (vgl. 5.2.1.2, S. 63ff) wie auch STR-Fragmente (vgl. 5.2.1.3, S. 66ff) ohne übermäßige degradierungstypische Artefakte zu amplifizieren sind. Bemerkenswert ist allerdings, daß bei der Fragementlängendetektion aus Pergamenten, die Länge des reproduzierbaren Amplikons 190bp nie überschreitet. Dies spricht möglicherweise für schnelle, kurzfristige aber effektive hydrolytische Degradierung der DNA und anschließendes Ausbleiben weiterer intensiver Degradierungsschäden und kann vielleicht auf den Prozess des Entfleischens zurückgeführt werden, der durch den des Trocknens abgelöst wird.

\subsection{DNA-Extraktion}

Um historische Daten auch in größerem Maßstab sammeln zu können, bedarf es einer effizienten Extraktionsmethode. Mit der Chelexmethode (nach Walsh et al. 1991) konnte ein unkompliziertes und effektives Verfahren gewonnen werden, DNA aus Pergamenten zu isolieren. Da es sich bei dem Ausgangsmaterial häufig um kulturhistorisch wertvolle Objekte handelt, wurden Versuche unternommen, die notwendige Größe einer Probe zu ermitteln bzw. die Ausbeute aus kleinen Proben zu erhöhen. Die hierbei verwendete spektralphotometrische Analyse erfasst allerdings nur den absoluten Wert an DNA-Menge und berücksichtigt nicht den Ursprung bzw. den Degradierungsgrad der Moleküle.

Tabelle 7 (S. 62) zeigt, daß der anzunehmende lineare Zusammenhang zwischen Probengröße und DNA-Ausbeute Zufallsschwankungen unterworfen sein kann. Außerdem sind die absoluten Werte nicht unbedingt aussagekräftig im Sinne einer Vorhersage des PCR-Erfolgs. So konnte aus einem $25 \mathrm{~mm}^{2}$ großen Stück von PA12 ein STR-Profil gewonnen werden; aus einem gleich großen Stück der Probe PA 16 mit etwa gleicher DNA-Konzentration war dies nicht möglich. Ein weiterer Versuch (Tabelle 8, S. 62) zeigte, daß die Ausbeute an DNA vom Volumen der Inkubationslösung Chelex nicht abhängig ist.

Die Inkubationszeit spielt indessen eine wesentliche Rolle für die absolute DNAAusbeute. Tabelle 9 (S. 62) zeigt deutlich, daß ein Erhöhen der Inkubationszeit 
von $3 \mathrm{~h}$ auf $21 \mathrm{~h}$ die Ausbeute auf 110- 450\% der ursprünglichen Menge erhöht. Dabei ist zudem zu beobachten, daß die Verbesserung vor allem für kleinere Fragmente gilt. Während die $25 \mathrm{~mm}^{2}$ großen Proben Steigerungen um 10-110 \% aufweisen, enthalten die $7 \mathrm{~mm}^{2}$ großen Proben nach $21 \mathrm{~h}$ Inkubationszeit Zunahmen der Ausbeute an DNA von 277 bis 333\%. Zusammenfassend kann festgestellt werden, daß die Chelex-Extraktion einen schnellen und effektiven Zugang zu alter DNA in Pergamenten ermöglicht. Das Verfahren, das ohne die Inkubationszeit ca. 20 Minuten in Anspruch nimmt, bietet v.a. bei großen Probenzahlen in Populationsstudien die geeignete Methode. Es gilt allerdings zu bedenken, daß die ChelexExtraktion durch die hohen Temperaturen selbst auch degradierenden Effekt auf die DNA hat, so daß für kulturhistorisch wertvolle und stark degradierte Proben ein zeitintensiveres, dafür aber schonenderes Verfahren, wie etwa die Silikafiltertechnik von Qiagen, empfohlen wird.

\subsubsection{3 mtDNA-Sequenzierung}

Bei der mtDNA-Sequenzierung erwies sich Pergament als ausgesprochen unkompliziertes Ausgangsmaterial. Die wenigen Inkonsistenzen, die bei der Sequenzierung eines Trampeltierpergaments (Abb. 16, S. 63ff) zu sehen sind, sind letztlich eher auf Sequenzierartefakte zurückzuführen als auf Degradierungsphänomene, und beeinträchtigen die Identifikation solange nicht, als mehrere Sequenzen derselben Probe verglichen werden können. Die Speziesidentifikation eines Pergaments aus Kaninchenhaut (Oryctolagus cuniculus) zeigt, daß auch sehr kurze Sequenzen von nur 56bp (ohne Primer) zur eindeutigen taxonomischen Einordnung führen können. Die mtDNA-Sequenzierung des St. Gallener Klosterplans ergab Schaf als Ursprungsspezies, während ein morphologisches Gutachten bislang von einem Kalbspergament ausgegangen war (Jacobsen 1992). Während bei vielen Pergamenten die Spezies auch morphologisch eindeutig an typischen Strukturen der Porenbildung der Haut erkannt werden kann (Rück 1991), zeigt das Beispiel, daß selbst bei einem recht gut erhaltenen Stück wie dem des Klosterplans, Fehler 
unterlaufen können. In allen anderen Fällen stimmte die morphologische Bestimmung allerdings mit der molekulargenetischen überein.

\subsection{STR-profiling}

Im Rahmen der vorliegenden Untersuchung wurde zum ersten Mal das Verfahren der STR-Fragementlängenanalyse auf Pergamente erfolgreich angewendet. Die Technik entspricht weitestgehend dem Multiplex-Verfahren wie es bereits für humane Microsatelliten an prähistorischen Skelettelementen entwickelt wurde (Burger 1997, Burger et al. 1997). Für die Pergamente bovinen Ursprungs wurden allerdings Dinucleotid-Wiederholungseinheiten verwendet (Pfeiffer et al. 1999), welche erfahrungsgemäß in der Praxis gewisse Schwierigkeiten bei der Determinierung von Allelen gehäuft entstehen lassen (z.B. Hummel \& Schultes 2000). Es handelt sich hierbei vor allem um das Auftreten sogenannter Stotterbanden (z.B. Kimpton et al. 1993, als „shadow bands“ in Litt et al. 1993). Die favorisierte Theorie für ein Entstehen von Stotterbanden ist das PCR polymerase slippage (Weber \& May 1989); es wird dabei davon ausgegangen, daß repetitive DNA während der PCR vermehrt zur Bildung von Sekundärstrukturen neigt und die Polymerase im Rahmen der Neusynthetisierung des DNA-Doppelstrangs diese nicht erkennt und somit in der Regel eine Repeateinheit ausläßt. Findet dieser Ablesefehler in den frühen Zyklen statt, so wird das so synthetisierte Artefakt zum Competitor für authentische DNA-Stränge (Burger 1997, Schultes et al. 1997b). Da diese bei alter DNA ohnehin in geringer Kopienzahl vorliegen und alte DNA eventuell eher zur Bildung von Sekundärstrukturen neigt (Burger 1997), stellen Stotterbanden ein ernstzunehmendes Problem dar. Darüber hinaus ist bekannt daß das Auftreten von Stotterartefakten mit der Länge der Wiederholungseinheit negativ korreliert (z.B. Hummel \& Schultes 2000). Aus Tabelle 10 (S. 66ff) ist jedoch zu ersehen, daß bei gut erhaltener DNA in Pergamenten auch bei Verwendung von Dinucleotid-

Wiederholungseinheiten, typische STR-Artefakte die letztliche Genotypisierung aus mehreren Einzelallelbestimmungen nicht behindern. Von 144 Alleldetermina- 
tionen führten nur 14 zu STR-typischen Schwierigkeiten, wie allelic dropout, Stotterbanden oder unsicheren Allelen. Dennoch wäre es für zukünftige Untersuchungen von Vorteil, Systeme mit längeren Wiederholungseinheiten einzusetzen, um eventuelle Schwierigkeiten bei der Allelbestimmung auch für weniger gut erhaltene DNA zu reduzieren. Zum gegenwärtigen Zeitpunkt werden Routineuntersuchungen in der Zucht- und Haustiergenetik noch mit DinucleotidWiederholungseinheiten durchgeführt (z.B. Pfeiffer \& Brenig 1998) obwohl Tetranucleotid-Systeme aus technischer Sicht zu bevorzugen wären. Somit sind auch die meisten Vergleichsdaten auf Populationsebene nur für DinucleotidSysteme zu erhalten. Es gilt nun abzuwägen, ob die Vorteile, die der Einsatz von Tetranucleotid- Wiederholungseinheiten zweifellos bietet, das Fehlen von Vergleichsdaten aus modernen Rinderpopulationen überwiegt. Da die moderne Zuchtpraxis zu hohen Inzuchtsraten unter den Rindern führt, sind heutige Populationen ohnehin ein anthropogenes Artefakt, das eher moderne Wirtschaftsstrukturen widerspiegelt und wenige Aussagen über populationsgenetische Aspekte der Entwicklung historischer Rinderherden zuläßt. Tabelle 11 (S. 68) zeigt, daß Allele aus alten Pergamenten in modernen norddeutschen Rinderpopulationen nur sehr selten auftauchen. Wegen der zu hohen Diskrepanz wären statistische Vergleiche mit unterschiedlichen modernen Populationen folglich zwecklos. Insofern wären Untersuchungen an historischen Rinderpopulationen ohnehin auf eigene Referenzdaten angewiesen. Demnach sollten künftige aDNA-Untersuchungen boviner Microsatelliten den Weg der technisch unkomplizierteren TetranucleotidWiederholungseinheiten wählen.

\subsection{Bedeutung und Perspektiven}

Das DNA-Profiling von Pergamenten im Speziellen und von Sachüberresten im Allgemeinen ist ein Werkzeug, um isolierte Fragmente eines Gegenstandes einander zuzuordnen. Dieses Prinzip, das bereits in seiner Anwendung an menschlichen Skelettfunden vorgeführt wurde (Schultes et al. 1997a, Gerstenberger et al. 1998), wäre vor allem in Hinblick auf die Rekonstruktion der religiösen Texte der sogenannten Qumran-Rollen vom Toten Meer von Interesse (Reed \& Poole 1964, Par- 
ry \& Ricks 1996, Woodward et al. 1996). Die Möglichkeit, sowohl mtDNA als auch ncDNA aus historischen Pergamenten $\mathrm{zu}$ isolieren und $\mathrm{zu}$ analysieren, ist aber nicht nur ein nutzvolles Werkzeug für Restauratoren, Historiker und Kodikologen, sondern eröffnet zugleich Perspektiven für biologische Aspekte der Haustierkunde, Agrar- und Umweltgeschichte. Wie aus Tabelle 11 (S. 68) zu ersehen ist, sind die meisten historischen Allele in modernen Populationen sehr selten oder fast ganz abwesend. Sollte es möglich sein, die Datenlage für historische Tiere zu erweitern, so könnte ein Einblick in Herkunft und Handel von tierlichen Rohstoffen aber auch in Art und Umfang historischer Herdenhaltung und Zuchtpraxis gewonnen werden. Neben STR-Profilen würde sich D-loop-Sequenzen der mtDNA für solche populationsgenetischen Fragestellungen anbieten.

\subsubsection{Leder}

Eine besondere Rolle unter den kollagenhaltigen Materialien spielt das Leder. Der Degradierungsgrad von Leder unterscheidet sich wegen des Fertigungsprozesses von dem roher Haut oder Pergaments. Häufig werden Tierhäute vor der Lederherstellung mit Salz konserviert. Erst kurz vor dem Enthaaren werden die Häute wieder ,geweicht" und damit in den schlachtfrischen Zustand versetzt (Reed 1972). Der haarlockernden bzw. -entfernenden alkalischen Quellung bzw. Äscherung samt mechanischer Nachbehandlung kann eine Neutralisierung in Verbindung mit einer fermentativen Beize folgen. Dem schließt sich die eigentliche Gerbung nach unterschiedlichsten Verfahren an (pflanzliche, Alaun-, Tran-, kombinierte Gerbung) (Reed 1972).

Organische Gerbstoffe sind meist pflanzliche Gerbsäuren (wie alle Gerbsäuren phenolischer Natur), die aus Holz, Rinden, Früchten und Blättern gewonnen werden (Reed 1972). Eine weitere Form organischer Gerbstoffe sind Aldehyde, die bei der Sämischgerbung mit Seetiertranen entstehen. Seetiertrane werden darü- 
berhinaus neben Eigelb und anderen wasserverträglichen Fettungsmitteln zur Fettung der noch nassen Leder nach der Gerbung verwendet (Reed 1972).

An das Gerben und Fetten schließt sich bei der Lederherstellung die Trocknung und der als „Zurichten“ bezeichnete Prozess der Nachbehandlung (Pressen, Biegen, Färben etc.) an.

Der geschilderte Prozess der Lederherstellung macht deutlich, daß hierbei die DNA der Tierhaut, bedingt durch stark basische bzw. saure Lösungen, unterschiedlichen hydrolytischen und oxidativen Degradierungmechanismen unterzogen ist, die ein Überleben endogener DNA unwahrscheinlich machen (Burger et al. 1999a). Dies spiegelt sich in den Ergebnissen dieser Untersuchung wieder.

Während etwa die Hälfte aller untersuchten Pergamente reproduzierbare DNA aufwies, konnten für Leder nur wenige Ergebnisse erzielt werden, wobei diese darüber hinaus nie voll und ganz reproduzierbar waren. Abbildung 19 (S. 70) in Kapitel 5.2.3 verdeutlicht dies. Noch schlechter sind die Erhaltungsaussichten von archäologischem Leder, das meist unter nassen anaeroben Bedingungen gefunden wird. Hier tritt neben die feuchte Lagerung noch die Kontamination des Materials mit organischen Geopolymeren, Humin- und Fulvosäuren hinzu. Der Einfluß dieser hochvariablen Verbindungen auf die DNA kann ambivalent sein, zumindest verhindern sie aerobische Aktivität (Eglinton \& Logan 1991), was unter anaeroben Bedingungen keine Rolle spielt. Entscheidend ist allerdings die Tatsache, daß die Huminsäuren nur schwer vom Material zu trennen sind und ausgiebige Waschschritte nötig machen, da sie als Inhibitor der enzymatischen Reaktionen in der PCR auftreten. In Verbindung mit der Anwesenheit von zusätzlich inhibierenden Gerbstoffen (auch Polyphenole) führte dies in keinem Fall zu erfolgreichen Amplifikationen (vgl. Abb. 20 und Tabelle 12, Kapitel 5.2.4, S. 71f). 


\subsubsection{Leime, Bindemittel und Öle}

\subsubsection{Prähistorische Felsbilder}

Natürliche Pigmente können organischer (z.B. Sepia oder Indigo) oder anorganischer Natur sein. Anorganische Pigmente werden unterteilt in Erdpigmente (Kreide, Ocker, Umbra), Mineralpigmente (Chromgelb, Mennige) Metallpigmente (Bronzen) und Kohlenstoffpigmente (Graphit). Um natürliche Pigmente zu einer haftenden Farbe zu verarbeiten, bedarf es eines Bindemittels. Da anorganische Pigmente, die hier in erster Linie in Frage kommen, selbst keine DNA enthalten, kommen nur die organischen Bindemittel als potentielle DNA-Ressource in Frage. Für prähistorische Zeiten ist hierbei in erster Linie an pflanzliche Säfte, tierliches Fett oder Eiweiß zu denken (vgl. Reese et al. 1996). Die Suche nach aDNA aus Felsbildern begann, als Publikationen bekannt wurden, die Proteine in Felsbildern und auf Steinwerkzeugen nachgewiesen zu haben vorgaben (Loy 1983, 1990, 1993, Loy et al. 1990, Loy \& Hardy 1992, Loy \& Matthaei 1994). Darüber hinaus war es mehrfach gelungen, Felsbilder zu datieren (Valladas et al. 1990, Chaffee et al. 1994, Ilger et al. 1996). Reese et al. veröffentlichten daraufhin (1996) bovine Sequenzen aus einem Felsbild aus der Lower Pecos River Region, Texas, USA. Die Proteinnachweise v.a. der Arbeitsgruppe um Thomas Loy gerieten inzwischen mehr und mehr in Kritik (Downs \& Lowenstein 1990, Hyland et al. 1990, Smith \& Wilson 1990, Nelson 1991, Smith \& Wilson 1992, Gillespie 1997, Fiedel 1996). Die Frage, woher der Kohlenstoff für die Datierungen der Felsbilder stamme, wurde von Gillespie (1997) überzeugend beantwortet; weder Proteine noch DNA könnten mengenmäßig ausreichen, um Kohlenstoffdatierungen an Felsbildern vorzunehmen, vielmehr handelt es sich um Kalziumoxalat, welches zumindest bei den australischen Felsbildern die überwiegende organische Fraktion ausmacht. In Ausnahmefällen kommt auch Kohle als Pigment vor (Van Der Merwe et al. 1987, Valladas et al. 1990, Clottes 1996) und kann datiert werden.

Letztlich waren die angeblichen Nachweise von biologischen Spuren in Felsbildern nicht mehr plausibel. Auch der DNA-Nachweis von Reese et al. (1996) kann im Spiegel der Erfahrungen mit Kontaminationen durch bovine DNA und in An- 
betracht der Tatsache, daß es sich um ein Labor für Rindergenetik handelte, in dem die Untersuchungen ohne die einwandfreie Trennung von prae- und postPCR-Räumlichkeiten vorgenommen wurden, in Frage gestellt werden. Auch die vorliegende Untersuchung, der Felsbildproben vom selben Fundplatz zugrundelagen, konnte die Authentizität der Resultate von Reese und Kollegen nicht stützen. Alle tierlichen Sequenzen waren mit rezentem Bos taurus identisch und nicht zu unterscheiden von immer wieder auftretenden spontanen, unsystematischen Kontaminationen.

Darüber hinaus wurden Untersuchungen an den texanischen Felsbildern mit Chloroplasten-DNA durchgeführt. Dies leitet über zu einem prinzipiellen Problem, das in Kapitel 6.1.6 (S. 104f) unter „Ungeschützte Materialien“ näher ausgeführt wird.

\subsubsection{Historische Werkstoffe}

Historische Leime wurden in Europa durch Auskochen kollagenhaltigen Materials, wie Knochen, Fischgräten und Pergamentabfälle hergestellt (Hodgins 1999). Der Leim aus der Schwimmblase des kaspischen Störs, der Hause, gilt als bevorzugte organische Leimart, wie sie noch heute zur Restaurierung v.a. von Manuskripten verwendet wird. Die DNA-Sequenz eines gelösten kommerziellen Hausenblasenleims stellte sich allerdings als die der Spezies Rhodeus ocellatus (Cyprinoidea) heraus. Die Angaben des Herstellers waren folglich falsch.

Die Möglichkeit DNA aus Leimen und Bindemitteln zu isolieren, erschließt einen wesentlichen historischen Werkstoff der weiteren Analyse. Kaum ein Gegenstand des Handwerks, des Kunsthandwerks oder der bildenden Kunst kommt ohne Leime und Bindemittel aus. Sollte es weiterhin möglich sein, aus historischen Leimund Bindemittelspuren deren Identität und Herkunft bestimmen zu können, erfüllte dies ein wesentliches Desiderat archäometrischer Forschung.

Auch aus Kasein, Körnerhautleim und Hasenleim war DNA zu gewinnen. Alle rezenten Proben ergaben Bos taurus als Sequenz. Während in historischen Werkstoffen mit geringem DNA-Gehalt bovine Sequenzen potentiell als Kontaminatio- 
nen zu werten wären, kann dies für die rezenten Werkstoffe (bis zu 10 Jahre) in Anbetracht der relativ hohen DNA-Ausbeuten (s. Tabelle 13, Kap. 5.3.2, S. 73f) als unwahrscheinlich betrachtet werden. Es ist allerdings nicht erstaunlich, daß bei allen Stoffen Bos taurus festzustellen war, da nach Auskunft von Restauratoren in modernen organischen Bindemitteln immer ein hoher Anteil von „Rindergelatine“ $\mathrm{zu}$ finden ist. Möglicherweise geht dies auf die Abfallverwertung der modernen Massentierhaltung zurück.

\subsubsection{Inhaltsreste (prä)historischer Behälter}

Der klassische Zugang (in der Anthropologie und Archäologie) zur Rekonstruktion (prä)historischer Ernährungsweisen ist der der Analyse von Spurenelementen (z.B. Schutkowski 1995, Fabig 1998) oder stabilen Isotopen (z.B. Schwarcz \& Schoeninger 1991, Bocherens 1997) von Knochenfunden. Archäologische Nahrungsreste können darüber hinaus direkt in den Behältern zur Nahrungszubereitung bzw. -aufbewahrung befundet werden. Hierzu beschränken sich die Analysen bislang auf Pollenanalysen (z.B. Rösch 1997) und Lipidanalysen (z.B. Evershed et al. 1999).

Die ethnologische Sammlung des Völkerkundemuseums in Berlin/Dahlem bietet eine einmalige Gelegenheit, prähistorische Topfinhalte mittel- und südamerikanischer Herkunft hinsichtlich ihres organischen Inhaltes zu studieren. Es existieren eine Reihe ungewaschener Behälter, die bis zu mehrere Zentimeter dicke organische Inkrustierungen aufweisen. Das bisweilen harzige und manchmal duftende Material konnte erfolgreich mit einer kombinierten GuanidiniumthiozyanatCTAB-Phenol/Chloroform-Methode aufgereinigt werden. PCR-Amplifikationen führten zur Identifikation pflanzlicher DNA. Da die meisten Proben dickere Schichten Materials aufwiesen, konnte durch die Entfernung der Oberfläche eine spätere Kontamination der Proben durch Pollenflug ausgeschlossen werden. Die Tatsache, daß von 24 Proben nur zwei authentische Sequenzen lieferten, kann mit den Eigenschaften des Materials selbst, seiner Herkunft aus wärmeren Klimaten oder auch mit der durchaus harschen Extraktionsmethode, die nötig ist, um die 
ungeklärte harzig-schwarze Konsistenz der Proben aufzulösen, erklärt werden. Die Identifizierung der Proben ergab, daß es sich um Pflanzenreste aus den Ordnungen der Zingiberales (IVCa1905) und der Lamiales (IVCa1855) handelte. Eine höhere Auflösung ist für diese Taxa nicht möglich (s. in der Methodendiskussion Kap. 6.3.3.2, S. 133).

Die Zingiberales oder Blumenrohrartige sind eine tropisch-subtropische Ordnung der Commelinidae mit fünf Familien. Diese sind die Musaceae (Bananengewächse), die Cannaceae, die Zingiberaceae (Ingwergewächse), die Marantaceae (Pfeilwurzgewächse) und die Strelitzaceae. Während alle Spezies der Ingwer- und Bananengewächse paläotropisch sind, ist die Familie der Cannacea mit ihrer einzigen Gattung Canna (Blumenrohre) mit über 30 Arten in Mittelamerika heimisch. Eine Rolle als Nahrungsmittel spielen die Rhizomknollen von C. edulis, aus denen ein als Queensland-Arrowroot bekanntes Stärkemehl gewonnen wird. Von den Strelitzaceae existieren zwei Gattungen, die im tropischen Amerika heimisch sind. Es sind dies die Gattung Strelitzia mit vier Arten und Heliconia, die mit 50 Arten dort vertreten ist. Die Marantaceae sind weltweit verbreitet und bestehen vor allem aus Kräutern. Die Pfeilwurz (M. arundinacea) ist eine bis zu 3m hohe Staude, die $50 \mathrm{~cm}$ lange Ausläufer mit hohem Stärkegehalt hervorbringt. Sie wird in Südamerika wegen ihrer leichten Verdaulichkeit als Kleinkind- und Diätnahrung verwendet.

Die Lamiales oder Lippenblütlerartigen sind eine Ordnung der Asteridae mit fünf Familien und über 6000 Arten in fast 300 Gattungen. Wichtigste Familien sind die Verbenaceae (Eisenkrautgewächse), die Labiatae (Lippenblütler) und die Callitrichaceae (Wassersterngewächse).

Welchen Spezies oder Gattungen die gefundenen Sequenzen tatsächlich zuzuzordnen sind bleibt ungeklärt. Im besten Falle können, solange keine besser auflösenden Systeme zur Verfügung stehen, Hypothesen generiert werden, die entweder durch additive Sequenzierungen weiterer DNA-Fragmente oder durch den Nachweis nicht biologischer Moleküle mithilfe anderer Methoden (z.B. HPLC, GC/MS) überprüft werden können. Auch wenn sich der rbcL-locus gerade hier als besonders schwach auflösend erwiesen hat, so sind die Resultate dennoch erfolgverspre- 
chend für weitere Untersuchungen. Sollte die Erfolgsrate durch verfeinerte Extraktionsmethoden verbessert werden können, so bietet sich auf der Basis der vorliegenden Untersuchung ein überaus interessanter Zugang zu Fragen der Ernährungsrekonstruktion.

Ursprünglich ergab der Abgleich der Probe CaIV 1855 mit Sequenzen in GenBank mithilfe des Programms Blast Search (Altschul et al. 1997) die Spezies Martinella obovata als ähnlichstes Taxon. Bei dieser Spezies handelt es sich um eine lianenartige Pflanze Süd- und Mittelamerikas, die lange Kapseln bildet, deren Inhalt noch heute von Indianern als Augensalbe verwendet wird. Das Ergebnis mußte jedoch revidiert werden, nachdem, wie in Abbildungen 23 und 24 (S. 75f) gezeigt wird, neue Einträge in GenBank einen höheren Ähnlichkeitsgrad zeigten. Dennoch bleibt festzustellen, daß über die Identizierung pflanzlicher DNA aus Behältern die Möglichkeit besteht, nicht nur Nahrungsbestandteile, sondern auch alle anderen biologischen Stoffe, wie pharmakologische Substanzen, zu identifizieren.

Bei einem weiteren Fund, der sogenannten „Wurstpelle“ von Dürrnberg, Österreich (Latène A, Stöllner \& Dobiat 1998, Dobiat \& Stöllner 1997) konnten Inhaltsreste auf dem Genusniveau identifiziert werden. Es handelte sich hierbei um kleine Bröckchen, die in den Falten und an der Innenfläche einer zugeschnürten Tierhaut gefunden wurden. Die Ansprache als „Pelle“, die Darm als Material impliziert, erwies sich - wie bereits oben erwähnt - durch die mikroskopische Analyse, welche typische Hautsrukturen wie Haare und Poren erkennen lies, als falsch. Die cpDNA-Analyse konnte die Anhaftungen als dem Genus Salvia (Salbei) zugehörig identifizieren. Dabei steht die Sequenz den wilden Salbeiarten näher als dem heute gebräuchlichen Küchensalbei.

Die Kombination mikroskopischer und paläogenetischer Untersuchungen konnte somit zeigen, daß es sich bei der „Wurstpelle“ vom Dürrnberg um einen Behälter handelte, in dem wilder Salbei oder ein Gemisch, welches Salbei beinhaltete, aufbewahrt wurde und daß Salbei in seiner nicht domestizierten Form bei den Kelten Mitteleuropas als Nahrungsmittel benutzt wurde (Dobiat et al. 2000, Burger et al. 2000a, b). 
Einen besonderen Fall von Gefäßinhalten stellen die Nachgeburtsbestattungen dar. Der seit dem Mittelalter vor allem im südlichen Mitteleuropa bekannte Brauch, die Plazenta nach der Geburt eines Kindes in einem Gefäß unter einem Baum, in einem Keller und möglichst „wo weder Sonne noch Mond hinscheint“" zu begraben, ist bis ins 20 Jahrhundert zumindest für Südwest-Deutschland belegt (AdeRademacher \& Sartorius 1997). Bei den meisten angeblichen Nachgeburtstöpfen ist nicht mit eindeutiger Sicherheit belegt, ob es sich wirklich um solche handelt. Der Nachweis wäre mit der Isolierung reproduzierbarer Microsatelliten-DNA sowohl des Kindes als auch der Mutter zu führen gewesen. Die Verfüllung der Töpfe mit Erdmaterial stellte die Analysen vor technische Schwierigkeiten, die auch durch eine kombinierte Guanidiniumthiozyanat-CTAB-Phenol/ChloroformExtraktionsmethode nicht vollständig gelöst werden konnten. Aber selbst in Proben, deren enzymatische Amplifikation nach der Extraktion nicht inhibiert war, konnten keine reproduzierbaren Microsatelliten-Allele festgestellt werden (Burger \& Großkopf 1997a).

Mit der Guanidinthiocyanat-Phenol/Chlorophorm-Methode konnte eine Methode etabliert werden, die in der Lage ist, Proben mit großen Anteilen an Erdreich für die PCR aufzureinigen. Die Methode kann, auch wenn die Untersuchungen in diesem Fall erfolglos verliefen, als Basis genommen werden für die DNA-Isolation aus Böden oder für stark mit Erdreich kontaminierte Proben.

\subsubsection{Archäologische Kleinfunde (Textile, Pflanzen, Leder)}

Unter feuchten und anaeroben Bedingungen können sich organische Materialien in Erdbestattungen oder Siedlungen erhalten. Häufig handelt es sich um teildegradierte Überreste von Kleidung oder Grabbeigaben (z.B. Bartel 1998). Den in Tabelle 12 (Kap. 5.2.4, S. 71ff) und 14 (Kap. 5.6, S. 80f) dargestellten Funden aus Leder, Bast und Textilien ist ihre geringe Größe und ein feuchtes Liegemilieu gemeinsam. Die Tabellen zeigen, daß in allen Fällen weder cpDNA noch mtDNA 
meinsam. Die Tabellen zeigen, daß in allen Fällen weder cpDNA noch mtDNA erfolgreich amplifiziert und sequenziert werden konnte. Bodengelagerte Weichgewebe nehmen aufgrund ihrer durchlässigen Matrix Wasser, Sauerstoff und Mikroorganismen leicht auf. Zwar trägt die hohe Feuchtigkeit auch zu einem Anreichern von Huminsäuren im Fundstück bei, was aerobische Aktivität reduziert, aber zugleich führt sie selbst zu hydrolytischen und oxidativen Schäden der DNA. Folglich ist eine der Bedingungen, die $\mathrm{zu}$ einem morphologischen Erhalt von Weichgeweben führen können, nämlich die Feuchtigkeit, auch verantwortlich für die Degradierung der DNA in den Geweben.

Pflanzenteile wie Pollen, Blütenstaub oder Samen fallen in der Regel bereits frühzeitig der Microfauna und -flora des Bodens zum Opfer, wenn sie nicht unter besonderen Bedingungen erhalten bleiben (vgl. Rösch 1998). Besondere Erhaltungsbedingungen können ein metallhaltiges Liegemilieu (Glauburg), die Verkohlung des Materials oder der spezielle Fall eines Salzbergwerks (Dürrnberg) sein. Während die Verkohlung eines Fundes in der Regel mit der vollständigen Hitzedegradierung der DNA einhergeht und die Nähe von Metall zu hohen Oxidationsraten führt (abgesehen von den technischen Schwierigkeiten der Aufreinigung), bieten aus dem Salz geborgene Funde zumindest theoretisch bessere DNAErhaltungsbedingungen. Insofern sind von den organischen Materialien von Dürrnberg in Zukunft noch mehrere Ergebnisse zu erwarten, auch wenn bislang technische Schwierigkeiten diese noch verhinderten. Möglicherweise konnte bisher das Salz nicht vollständig aus den Tierhautfunden entfernt werden, ohne die DNA gleichzeitig auszuwaschen.

Zusammenfassend kann gesagt werden, daß kleinere bodengelagerte organische Funde ohne stabile Gewebsmatrix (wie bei Knochen und Zähnen) unter den meisten Umständen keine endogene DNA aufweisen. Dies gilt auch für artifiziell vor mikroorganismischen Befall geschützte Gewebe wie Leder. Nur unter besonderen Bedingungen wie trockenem und nicht $\mathrm{zu}$ feuchtem Liegemilieu sind positive Ergebnisse in Zukunft zu erwarten. 


\subsubsection{Ungeschützte Materialien (Felsbilder, Steinwerkzeuge)}

Materialien, die ungeschützte Oberflächen aufweisen, sind in zweifacher Hinsicht gefährdet. Zum einen durch Kontaminationen und zum anderen durch physikalisch-chemische Schäden, die unbehindert die Oberflächen des Materials passieren können. Während bei Knochen und Zähnen die gesamte mineralische Matrix schützende Oberflächen bietet, sind organische Gebrauchsspuren an Steinwerkzeugen oder Bindemittel in Felsbildern ungeschützt allen äußeren Einflüssen ausgesetzt. Die schädlichen Einflüsse auf die DNA von Felsbildern sind v.a. Photooxidation durch UV-Licht und Schäden, die durch den Metabolismus von Pilzen und Flechten verursacht werden. Daneben können (wie immer) Feuchtigkeit und hohe Temperatur eine entscheidende negative Rolle spielen. Für DNA in bodengelagerten Steinwerkzeugen stellen Mikroorganismen und Feuchtigkeit die entscheidenden Gefahren dar. Die Wahrscheinlichkeit, daß von der Benutzung herrührende DNA aus Blut- oder Weichgewebsresten an Werkzeugen ohne besonderen Schutz Jahrtausende in einem natürlichen Boden überleben kann, erscheint im Spiegel aller Erfahrungen sehr gering. Auch hier gilt in besonderem Maß, was bereits für die archäologischen Kleinfunde festgestellt wurde, daß nur unter besonders vorteilhaften trockenen und kühlen Bedingungen Einzelergebnisse erwartet werden können. Bei der Untersuchung von pflanzlicher DNA entsteht ein weiteres Problem. Werkzeuge und Felsbilder weisen keine tieferen geschützten organischen Schichten auf, wie etwa Koprolithen (Poinar et al. 1998) oder Gefäßinhalte, so daß keine Oberflächen mit möglichen Kontaminanten abgetragen werden können. Wenn also pflanzliche DNA in Felsbildern oder an Steinwerkzeugen nachgewiesen werden soll, wird es immer schwer fallen, die möglichen Ergebnisse in Abgrenzung zu Kontaminanten zu authentifizieren. Als Beispiel seien die texanischen Felsbilder dieser Untersuchung genannt. Zwei rbcL-Sequenzen, die aus Felsbildextrakten ermittelt werden konnten, wiesen Pflanzen-Genera auf, die beide nicht auf dem europäischen Kontinent, aber in Zentralamerika verbreitet sind. Folglich kann es sich nicht um Kontaminationen handeln, deren Eintrag während der Analyse im Labor stattfand. Jedoch bei einer ca. 1mm dicken Pigmentschicht, auch wenn die Oberflächen der Felsbildproben sorgfältig mit einem Skalpell abgekratzt wurden, kann aus pragmatischen Gründen eine Kontamination nicht 
wurden, kann aus pragmatischen Gründen eine Kontamination nicht ausgeschlossen werden.

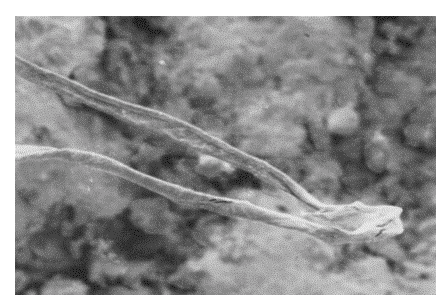

Abbildung 29: Rasterelektronenmikroskopische Aufnahme (ca. 100x) der Oberfläche eines Felsbildes (41VV75.4) mit nicht identifizierter pflanzlicher Auflagerung.

Abbildung 29 zeigt ein Beispiel einer kleinen pflanzlichen Struktur auf einem Felsbild, wie sie zu Dutzenden auf wenigen Quadratzentimetern zu sehen sind und als potentielle Kontaminatoren in Frage kommen. Außerdem ist damit zu rechnen, daß Pollen das Felsbild bereits kurz nach der Fertigstellung kontaminierten und somit zu einem scheinbar integrativen Bestandteil des Pigments wurden, bevor sich mineralische Überlagerungen bilden konnten (Burger \& Großkopf 1997b). Mit diesem Phänomen muß bei allen ungeschützten Oberflächen, die nicht von einem inneren Bereich deutlich zu trennen sind, also auch bei Pflanzenresten an Steinwerkzeugen gerechnet werden. 


\subsection{Methodendiskussion}

Die Methodendiskussion behandelt Aspekte, die zusätzlich zu denen, die im Zusammenhang mit den Materialien selbst entstanden sind, von Bedeutung sind. ${ }^{6}$ Zum einen handelt es sich hierbei um Grundlagen der molekularen Systematik, in erster Linie um die Wahl des richtigen locus und der optimalen Primer. Gerade im Bereich der taxonomischen Identifizierung von Spuren-DNA ist es von wesentlichem Interesse, zu wissen, wie sich Primer in einer Reaktion verhalten und welchen Einfluß die Basensequenzen von Primern und target auf das annealingVerhalten haben.

Desweitern werden im Folgenden Aspekte behandelt, die sowohl die vorliegende Arbeit selbst betreffen als auch als allgemeine aDNA-spezifische Fragestellungen über sie hinausweisen; darunter finden sich die Themen Kontaminationen, Gemische und Authentifizierung alter DNA.

\subsubsection{Strategien zum Primerdesign - Theorie und Praxis}

\subsubsection{Primer-Target-Bindungen}

Abbildung 30.1 zeigt das $\Delta$ G-Profil eines Primers wie es in der nicht mehr aktuellen Literatur (Erlich 1989, Saiki RK 1989, Innis MA et al. 1990, Innis \& Gelfand 1990, Rolfs et al. 1992, Diefenbach et al. 1995, Boehringer Mannheim 1995) empfohlen wurde. Neuere Literatur (z.B. Rychlik 1995a) empfiehlt inzwischen völlig unterschiedliche Profile für das Design von Primern (Abb. 30.3). Um die Diskussion hierüber führen zu können, müssen zuerst die für den Umgang mit der PCR wesentlichen Kriterienbegriffe (vgl. Diefenbach et al. 1995, Cha \& Thilly 1995, Burger 1997, Rameckers et al. 1997) rekapituliert werden (s. übernächste Seite).

\footnotetext{
${ }^{6}$ Stellenweise werden hierfür Resultate präsentiert, die sich nicht in Kapitel 5 unter „Ergebnisse“ wiederfinden, da sie nur hier im Zusammenhang einer weiterführenden Diskussion von Interesse sind.
} 

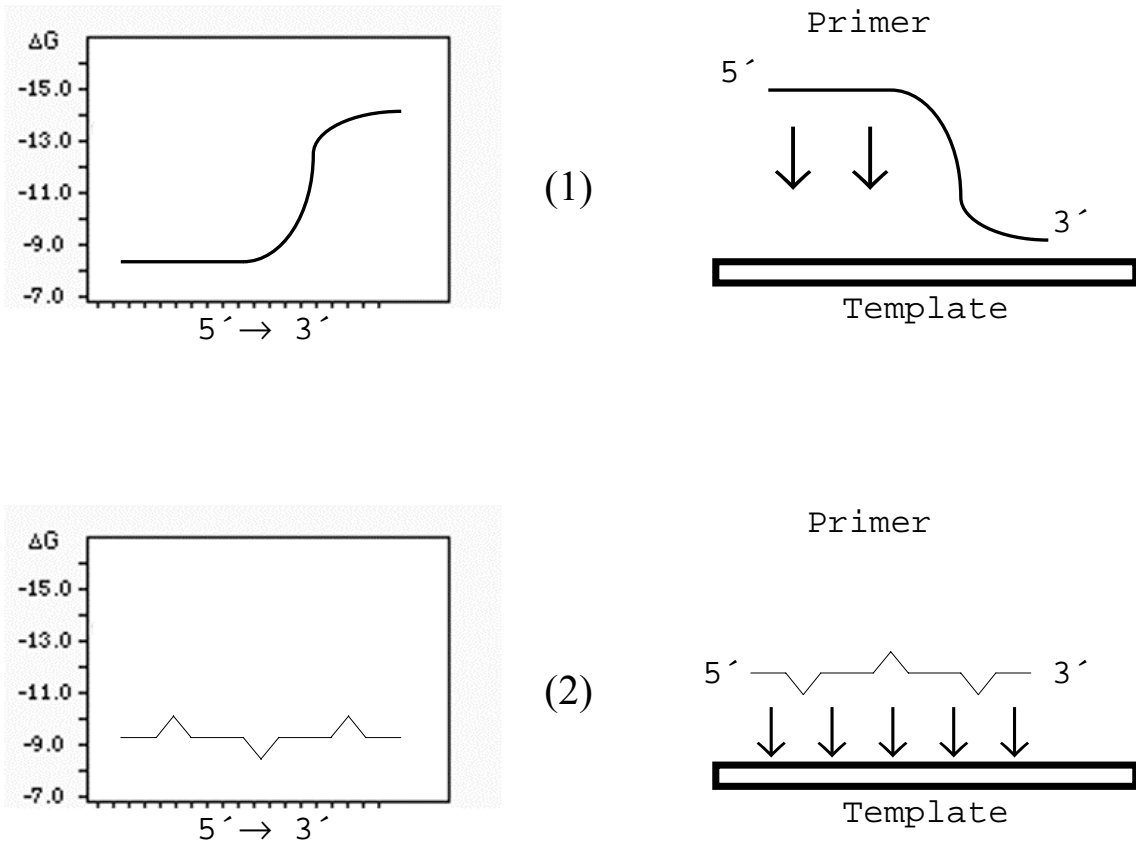

(1)

Template

(2)

Primer

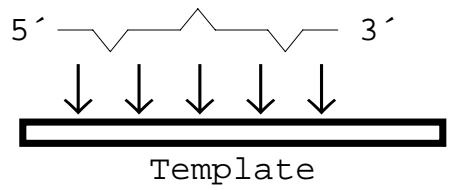

(3)
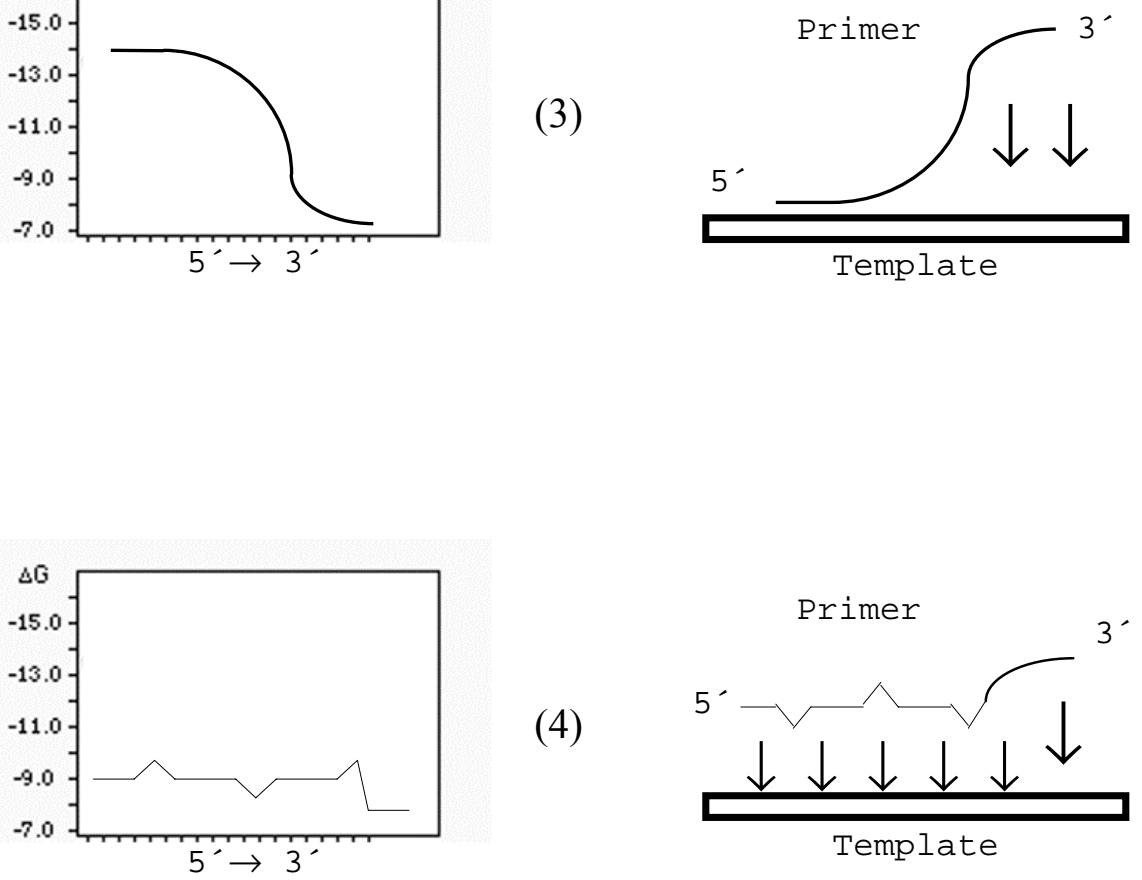

Abbildung 30.1-4: Vier theoretische Primermodelle. Links ist jeweils das $\Delta$ G-Profil dargestellt und rechts das anneal-Verhalten des Primers in der PCR. 
- Spezifität (bezüglich der zu amplifizierenden Sequenz)

- Sensitivität (bezüglich geringer Mengen an targets)

- Effizienz (die Ertragsmenge betreffend)

- Reproduzierbarkeit (aller Kriterien)

- Verläßlichkeit (im Sinne einer geringen Fehlerrate)

Die Kriterien sind nicht unabhängig voneinander zu betrachten. So sinkt die Effizienz bei allzu stringenter Spezifität bzw. Verläßlichkeit, sie sinkt aber auch bei mangelnder Spezifität. Die Sensitivität steigt mit steigender Spezifität, da durch einen hohen Grad an Spezifität konkurrierende, unspezifische Reaktionen verhindert werden, die Substrate verbrauchen und Enzyme blockieren. Mit steigender Sensitivität und Spezifität steigt auch die Reproduzierbarkeit, da auch geringe Mengen an targets spezifisch und verläßlich amplifiziert werden können. Bei der Amplifikation von aDNA sind Sensitivität und Spezifität die wichtigsten Kriterien. Auf Sensitivität der PCR-Parameter muß wegen der geringen Ausgangsmenge an targets geachtet werden. Spezifität ist wesentlich, da der Bildung unspezifischer Produkte in Folge des hohen Degradierungsgrades von aDNA entgegengewirkt werden muß.

Das Beispiel in Abbildung 30.1 zeigt einen theoretischen Primer, der sich durch ein vom $5^{\prime}$ - zum $3^{\prime}$-Ende aufsteigendes $\Delta \mathrm{G}$-Profil auszeichnet, dessen $\Delta \mathrm{G}$-Werte ${ }^{7}$ also sinken. Mit hoher Bindungsaffinität am 3'-Ende bindet der 3'-nahe Teil des Primers mit den ersten Basen schnell an jede komplementäre Sequenz und die Elongation kann erfolgen, ohne daß die Komplementarität für den Rest des Primers in Richtung 5'-Ende gewährleistet ist. Der Primer kann als effizient erscheinen, ist aber zugleich unspezifisch in seinem annealing-Verhalten und somit suboptimal. In Abbildung 30.3 ist idealtypisch das Profil der internen Stabilität eines Primers dargestellt, wie er in der neueren Literatur entworfen wird (Rychlik 1995a). Diese Primer zeichnen sich durch höhere $\Delta \mathrm{G}$-Werte am 3'-Ende aus und haben entsprechend eine niedrigere Bindungsaffinität. Am 5'-Ende fallen die $\Delta \mathrm{G}-\mathrm{Werte}$, so daß

\footnotetext{
${ }^{7}$ Die freie Energie $\Delta \mathrm{G}$ errechnet sich aus Enthalpie und Enthropie: $\Delta \mathrm{G}=\Delta \mathrm{H}-\mathrm{T} \Delta \mathrm{S}$, wobei $\Delta \mathrm{H}$ die Enthalpie, $\mathrm{T}$ die Temperatur und $\Delta \mathrm{S}$ Enthropie ist.
} 
der Primer von seinem 5'-Ende zuerst an das target bindet, und erst wenn zuletzt auch das 3'-Ende hybridisiert, kann eine Elongation erfolgen. Diese Strategie gewährleistet eine hohe Spezifität der Primer. Der Nachteil liegt darin, daß auch hier unspezifische Annealing-Vorgänge am 5'-Ende vonstattengehen. Primer werden an falsche Stellen gebunden und stehen dabei der richtigen Reaktion nicht zur Verfügung. Allerdings haben diese unspezifischen Bindungen in diesem Fall und im Gegensatz zu dem Beispiel in Abbildung 30.1 keine Folgen für die Entstehung unspezifischer Produkte, da das 3'-Ende für die Elongation nicht zur Verfügung steht.

Den theoretischen Idealfall stellt Abbildung 30.2 dar. Der hier dargestellte Primer zeichnet sich durch ein ausgewogenes $\Delta \mathrm{G}$ Profil aus. Idealer Weise sollte dieser Primer durchgängig gleichzeitig an das template binden und somit spezifischer reagieren, da alle Bereiche des Primers das Komplementaritätskriterium erfüllen müssen und nicht nur die letzten fünf oder ersten zehn Basenpaare.

Der Tatsache, daß dem 3'-Ende mehr Bedeutung beizumessen ist als anderen Teilen des Primers, trägt das Modell in Abbildung 30.4 Rechnung. Es stellt eine Modifikation von Abbildung 30.2 bzw. einen Kompromiß zwischen den Modellen von Abbildung 30.2 und 30.3 dar. Der Primer besitzt alle Vorteile wie der Primer in Abbildung 30.2 und zusätzlich eine Absicherung am 3'-Ende gegen unspezifische Elongation indem der $\Delta \mathrm{G}$-Wert gegenüber dem restlichen Primer ansteigt. Dies zieht wahrscheinlich einen gewissen Verlust an Effizienz gegenüber Modell 30.2 nach sich, trägt aber zu höherer Spezifität bei. 


\subsection{Sensitivität und Effizienz von (semi)universellen Primern in der Praxis}

Tabelle 16: Primer-target-Eigenschaften hinsichtlich der menschlichen Sequenz

\begin{tabular}{|l|l|c|c|c|}
\hline Primer & $\begin{array}{l}\text { Mismatch-Position } \\
\text { zu H. sapiens ab 3'-Ende }\end{array}$ & $\begin{array}{c}\text { Mismatch an } \\
\text { 3'-Position 1 }\end{array}$ & $\begin{array}{c}\text { Mismatch-Anzahl } \\
\text { des 3'-Pentamers }\end{array}$ & $\begin{array}{c}\text { Mismatch- } \\
\text { Anzahl gesamt }\end{array}$ \\
\hline & & & & 6 \\
\hline CyBa & $1,8,14,21,22,23$ & + & 1 & 6 \\
\hline CyBb & $3,7,9,15,18,21$ & - & 1 & 3 \\
\hline CytL & $1,13,15$ & + & 0 & 6 \\
\hline CytH & $6,15,16,17,18,19$ & - & 0 & 4 \\
\hline CB1a & $6,9,15,18$ & - & 1 & 4 \\
\hline CB1b & $3,9,18,21$ & - & 2 & 5 \\
\hline CB2a & $2,3,8,12,15$ & - & 3 & 6 \\
\hline CB2b & $2,4,5,8,11,17$ & - & 0 & 4 \\
\hline CB3a & $7,8,12,18$ & - & 1 & 4 \\
\hline CB3b & $3,15,18,20$ & - & 2 & 7 \\
\hline CB7u & $1,2,8,10,11,16,20$ & + & 1 & 5 \\
\hline CB71 & $3,6,12,18,21$ & - & 0 & 0 \\
\hline rR4a & - & - & 0 & 2 \\
\hline rR4b & 13,16 & - & 0 & 1 \\
\hline rR4c & 6 & - & & \\
\hline
\end{tabular}

Tabelle 16 listet die Primer-target-Eigenschaften der in dieser Untersuchung verwendeten Primer im Hinblick auf die menschliche Sequenz auf. Unter stringenten Amplifikationsbedingungen amplifizierten Primersysteme CyB und CB7 niemals eine menschliche Kontamination. Bei dem System Cyt wurden menschliche Kontaminationen selten, bei CB3 häufiger und bei rR4ac fast regelmäßig beobachtet. ${ }^{8}$ CyB und CB7 zeichnen sich durch einen 3'-mismatch des einen Primers und einen weiteren mismatch im 3'-Pentamer des zweiten Primers aus. Das Primersystem Cyt hat dagegen nur einen 3'-mismatch eines Primers aufzuweisen. Die Kontaminationsanfälligkeit von System rR4ac ist augenfällig, da es über keinen einzigen mismatch zur menschlichen Sequenz im 3'-Pentamer verfügt. Bei CB3 reicht ein mismatch im 3'-Pentamer immerhin aus, um die Kontaminationsrate zu senken. Die folgenden Ausführungen geben näheren Aufschluß über das Reaktionsverhal-

\footnotetext{
${ }^{8}$ Die Primersysteme CB1 und 2 bzw. rR4ab wurden zu selten benutzt um Aussagen treffen zu können.
} 
ten (semi)universeller Primer in Abhängigkeit von den jeweiligen Primer-targetBindungseigenschaften (vgl. auch Goodman 1995).

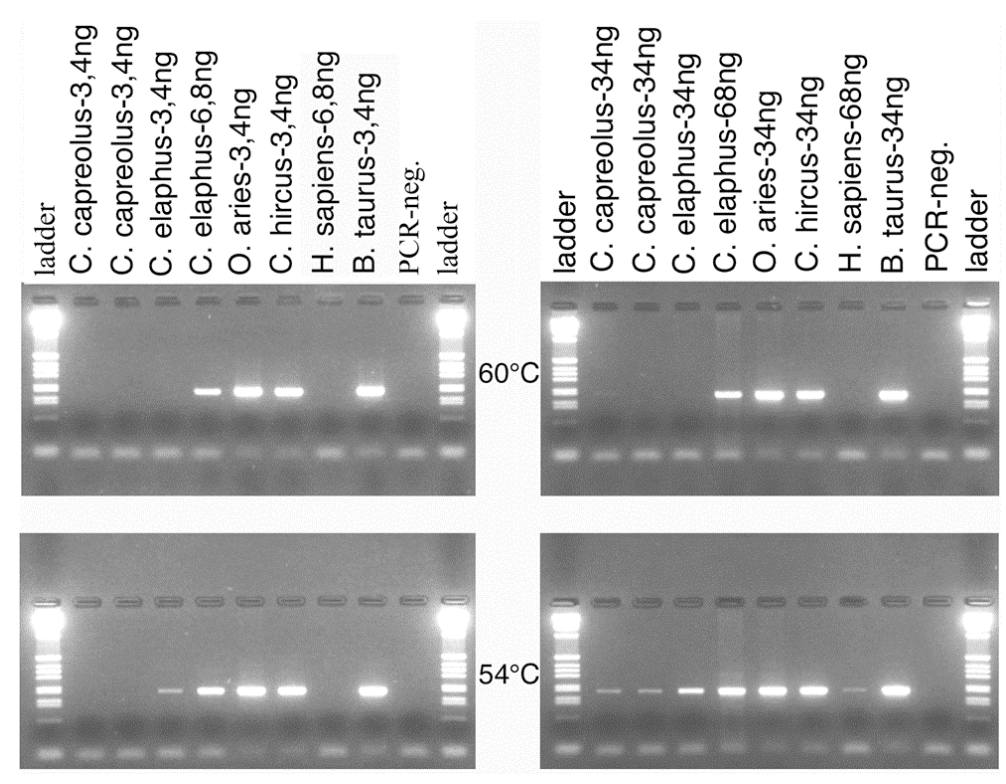

Abbildung 31: CB7-Amplifikation sieben unterschiedlicher Spezies mit variierenden DNAEinsatzmengen bei unterschiedlichen annealing-Temperaturen $\left(60^{\circ} \mathrm{C}, 54^{\circ} \mathrm{C}\right)$.

Abbildung 31 zeigt die Amplifikationsergebnisse einer CB7-PCR von sieben unterschiedlichen Spezies. Alle Proben mit Ausnahme der Ziegenprobe basieren auf einem Standard-Qiagen-Extraktionsprotokoll. Die Amplifikationen wurde mit zwei unterschiedlichen Temperaturen $\left(60^{\circ} \mathrm{C}\right.$ und $\left.54^{\circ} \mathrm{C}\right)$ und unterschiedlichen Einsatzmengen an DNA durchgeführt. Geht man davon aus, daß in $1 \mu \mathrm{g}$ DNA etwa 2-3 $\times 10^{5}$ templates einer Einzelkopiesequenz vorhanden sind (z.B. Rameckers et al. 1997, Findlay et al. 1997), so liegen den dargestellten Amplifikationen ca. $7 \times 10^{5}$ (3,4ng) bis $1,4 \times 10^{7}$ (68ng) mitochondriale templates zugrunde, unter der Annahme einer durchschnittlichen mtDNA-Kopienzahl von 700 pro Zelle. Die Agarosegelbilder sind im Zusammenhang mit dem Alignment der CB7-Primer in Abbildung 7 (Kap. 4.4, S. 46ff) zu sehen. 
Ziege, Schaf und Rind, die keine bedeutenden Fehlbindungsstellen mit den Primern aufweisen, reagieren unter allen Bedingungen und ergeben deutliche Banden. Reh, Hirsch und Mensch sind differenzierter zu betrachten. Die Sequenz des Rehs weist gegenüber Primer CB7u drei Fehlbindungsstellen auf, davon eine an zweiter 3'-Position. Gegenüber Primer CB71 existieren zwei Fehlbindungsstellen, eine davon an dritter 3'-Position. Die Sequenz des Hirschen weist gegenüber CB7u zwei (keine im 3'-Pentamer) und gegenüber CB71 vier Fehlbindungsstellen, davon eine an dritter 3'-Position. Die beiden Rehproben zeigen bei stringenten Bedingungen $\left(60^{\circ} \mathrm{C}\right)$ weder bei 3,4 ng Einsatz an DNA noch bei der zehnfachen Menge eine sichtbare Bande. Unter weniger stringenten Bedingungen $\left(54^{\circ} \mathrm{C}\right)$ weisen die Rehproben mit weniger DNA auch keine Bande auf, erst bei zehnfachem Einsatz (34ng) zeigen sich zwei schwache Banden. Hirschprobe 1 verhält sich ähnlich, zeigt aber bei $54^{\circ} \mathrm{C}$ auch mit der geringeren Menge DNA-Einsatzes $(3,4 n g)$ eine schwache Bande. Hirschprobe 2, die auf jeweils doppelter Menge DNAEinsatzes basiert (6,8ng bzw. 68ng), amplifiziert sowohl unter stringenten als auch weniger stringenten Bedingungen. ${ }^{9}$

Das Experiment verdeutlicht, daß beim Reh ein mismatch an zweiter Position bei beiden Primern die Spezies unter stringenten Bedingungen von der Amplifikation soweit ausschließt, daß die Nachweisgrenze des Agarosegels mit 32 Zyklen nicht erreicht wird. Die Sensitivität und damit die Effizienz der PCR sinkt erheblich. Ein mismatch an dritter 3'-Position bei nur einem Primer beim Hirsch behindert die Reaktion nicht in dem Maße, zumal es sich an dieser Stelle im Primer um ein G handelt, welches mit dem T des Hirschen eine wenn auch schwache Bindung eingehen kann (Hillis et al. 1996: 214). Sichere Ergebnisse sind indessen nur unter weniger stringenten Bedingungen gewährleistet. Auch ein mismatch der ersten beiden Positionen bei einem Primer und der dritten Position bei dem anderen, wie dies bei der menschlichen Sequenz der Fall ist, diskriminiert die Sequenz nicht völlig. Die Abbildung zeigt, daß bei nicht stringenten Bedingungen und der größeren DNA-Einsatzmenge eine schwache Bande zu sehen ist. Die Fehlbindungstellen

\footnotetext{
${ }^{9}$ Die Probe verhält sich an einer Stelle unregelhaft, da sie bei 6,8 ng eine Bande aufweist, während Hirschprobe 1 bei 34 ng keine zeigt
} 
am 5'-Ende der Primer scheinen theoriekonform nur eine untergeordnete Rolle zu spielen.

Das Gesagte wird ein weiteres Mal in Abbildung 32 verdeutlicht, in der das Ergebnis der Amplifikationen unterschiedlicher Mengen an Reh- und Hirsch-DNA sowohl für $62^{\circ} \mathrm{C}$ als auch $54^{\circ} \mathrm{C}$ annealing-Temperatur dargestellt ist. Bei $62^{\circ} \mathrm{C}$ amplifizierten zwei Rehproben und eine Hirschprobe extrem schwach. Bei $54^{\circ} \mathrm{C}$ ist $\mathrm{zu}$ beobachten, daß jeweils die Hirschprobe trotz gleicher Ausgangsmenge ein stärkeres Signal im Vergleich zu den Rehproben aufweist. Auch ist zu sehen, daß die Stärke des Signals deutlich mit der eingesetzten Menge an DNA korreliert. Bei Spezies, die keinen mismatch im 3'-Pentamer zu den beiden Primern aufweisen, wie Ziege, Schaf und Rind, konnte dieses Phänomen, das sicherlich einer Grenzsituation im Spurenbereich nahekommt, nicht beobachtet werden; hier ergeben auch kleinste Mengen DNA deutliche Banden (vgl. Abb. 31).

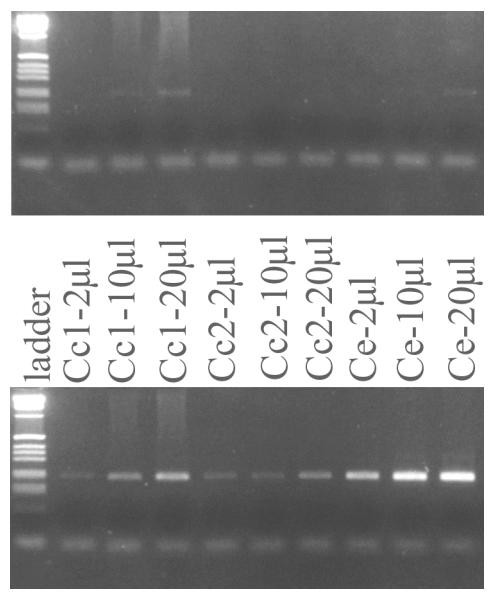

Abbildung 32: Amplifikate zweier Rehproben $(C c 1,2)$ und einer Hirschprobe (Ce) aus einer PCR mit annealing-Temperatur von $62^{\circ} \mathrm{C}$ (oben) bzw. $54{ }^{\circ} \mathrm{C}$ basierend auf unterschiedlichen Mengen DNA-Einsatzes (ca. 1,5 $n g / \mu l)$

Nachstehende Schlußfolgerungen können für aDNA-Analysen gezogen werden:

- Die Sensitivität eines Systems nimmt auch unter nicht stringenten Bedingungen bereits durch einen mismatch an dritter 3'-Position eines Primers deutlich ab (Beispiel Hirsch). 
- Unter stringenten Bedingungen reicht jeweils ein mismatch an zweiter 3'Position aus, um eine Spezies zu diskriminieren (Beispiel Reh).

- Unter nicht stringenten Bedingungen lautet die Mindestanforderung, um eine Spezies zu diskriminieren: Zwei 3'- mismatches an einem Primer und am anderen Primer ein mismatch an zweiter 3'-Position (Beispiel Mensch).

\subsection{Annealing-Temperatur in Theorie und Empirie}

Tabelle 17

\begin{tabular}{|l|l|l|}
\hline Primer & $\begin{array}{l}\text { Errechnete } \text { Annealing- } \\
\text { Temperatur* }\end{array}$ & $\begin{array}{l}\text { Empirische Annealing- } \\
\text { Temperatur }\end{array}$ \\
\hline $\mathrm{CyB}$ & $53{ }^{\circ} \mathrm{C}$ & $58^{\circ} \mathrm{C}$ \\
\hline $\mathrm{CB} 3$ & $49,9^{\circ} \mathrm{C}$ & $59^{\circ} \mathrm{C}$ \\
\hline $\mathrm{CB} 7$ & $52,2^{\circ} \mathrm{C}$ & $54^{\circ} \mathrm{C}-61^{\circ} \mathrm{C}$ \\
\hline
\end{tabular}

*nach Rychlik et al. (1990)

Tabelle 17 zeigt drei Primersysteme, für die mit dem Programm Primer Select (DNAStar Inc.) die theoretische annaeling-Temperatur nach Rychlik et al. (1990) berechnet werden konnte, im Vergleich zu denjenigen Temperaturen, die empirisch ermittelt wurden.

Die annealing-Temperatur wird in Abhängigkeit vom Schmelzpunkt berechnet. Für die Berechnung des Schmelzpunktes eines Oligonucleotids, Tm, wird im Datenpaket DNA-Star folgende Formel vorgeschlagen (nach Breslauer et al. 1986):

$$
\mathrm{Tm}=16,6 \log [\mathrm{Salz}]-273,15+\Delta \mathrm{H}:(\Delta \mathrm{S}+\mathrm{R} \ln (\mathrm{c}: 4))
$$

wobei „Salz“ die Konzentration an $\mathrm{Na}+$ in $\mathrm{Mol}$, $\mathrm{R}$ die molare Gaskonstante $1,987 \mathrm{cal} / \mathrm{mol}^{\circ} \mathrm{C}$ und $\mathrm{c}$ die Anfangskonzentration des Primers ist.

Die optimale annealing Temperatur, Ta, ist nach Rychlik et al. (1990)

$$
\mathrm{Ta}=0,3 \mathrm{Tm} \text { Primer }+0,7 \mathrm{Tm} \text { Produkt }-14,9
$$


wobei Tm Primer der minimale Tm der beiden Primer ist. Tm Produkt wird in Abhängigkeit vom GC-Gehalt der Sequenz nach Baldino et al. (1989) folgendermaßen berechnet:

$\mathrm{Tm}=81,5+16,6 \log [\mathrm{Salz}]+41(\mathrm{GC} \%): 100-65(\%$ Formamid $): 100-65$ :Länge des Produkts

Die Werte von errechneten und empirisch ermittelten Temperaturen weichen bei allen drei Primersystemen erheblich voneinander ab. Die Differenzen betragen $5^{\circ} \mathrm{C}, 9,1^{\circ} \mathrm{C}$ bzw. $8,8^{\circ} \mathrm{C}$ (unter stringenten Bedingungen). Für $\mathrm{CB} 7$ konnte oben gezeigt werden, daß eine annealing-Temperatur von $54^{\circ} \mathrm{C}$ sogar 3 '-Fehlbindungen von zwei Basenpaaren zuläßt. Der errechnete Wert von $52,2^{\circ} \mathrm{C}$ fällt folglich viel zu niedrig aus, um eine spezifische Reaktion zu gewährleisten. ${ }^{10}$ Unter diesen Gesichtspunkten müssen die theoretisch berechneten $\mathrm{T}_{\mathrm{a}}$-Werte nach Rychlik in Frage gestellt werden. Annealing-Temperaturen, die mit einem weiteren Programm (Oligo.4) errechnet wurden, lagen sogar noch unter den in Tabelle 17 aufgeführten nach Rychlik. Über die Gründe der Abweichung der Praxis von der Theorie läßt sich nur spekulieren. Sicherlich funktionieren die meisten PCR-Anwendungen vor allem im klinischen Bereich auch unter nicht stringenten Bedingungen, aber besonders für Anwendungen in Grenzbereichen der Nachweistechnik, muß die annealing-Temperatur empirisch genau ergründet werden. Das in Kapitel 6.2.1.1.1 vorgeführte Beispiel des Primers CB7 ist ein klassischer Beleg für die feinen Differenzierungen (und Fehler), die aus unterschiedlichen Temperaturen entstehen können.

\footnotetext{
${ }^{10}$ In manchen Fällen kann es erwünscht sein, daß unspezifische Reaktionen ablaufen, wie z.B. bei ansatzfreiem screening mit universellen Primern. Der errechnte $T_{a}$ sollte indessen auf eine spezifische und stringente Reaktion zielen.
} 


\subsubsection{Primer-Primer-Bindungen}

\subsection{Primerdimere}

Primer können während der PCR sowohl mit den gleichen Primern Bindungen eingehen als auch mit dem jeweils anderen Primer der Reaktion (z.B. Rychlik 1995b). In beiden Fällen stehen die gebundenen Primer der Reaktion nicht mehr zur Verfügung. Wenn ein 3'-Hydroxylende in die Bindung involviert ist, können Di- und Multimere entstehen, die in Konkurrenz zur erwünschten Reaktion treten und diese weniger spezifisch ablaufen lassen können. Folgende Kriterien haben sich als erfolgreich zur Vermeidung unspezifischer Primer-Primer-Bindungen erwiesen:

- Vermeiden von Bindungen näher als 3 Nucleotide vom 3'-Ende.

- Vermeiden von vier benachbarten Bindungen näher als fünf Nukleotide vom 3'Ende.

- Vermeiden von mehr als vier benachbarten Bindungen.

- Maximaler $\Delta \mathrm{G}-\mathrm{Wert}$ von $8,5 \mathrm{kcal} / \mathrm{mol}$.

\subsection{Hairpins}

Schleifen aufgrund von Selbstkomplementarität von Primern, sogenannte hairpins, ergeben zwar keine Produkte, die länger sind als die Primer selbst, hindern aber die Primer an der Bindung mit dem gewünschten target. Beim Primerdesign sollte daher frühzeitig auf Vermeidung von revers-komplementären Strukturen (z.B. AATT, GACT, AAGATCTT) an den Polen oder in der Mitte des Oligonucleotids geachtet werden. Sollten sich dennoch Hairpins bilden, so wird empfohlen, einen $\Delta \mathrm{G}-$ Wert von $8,5 \mathrm{kcal} / \mathrm{mol}$ nicht zu überschreiten.

Tatsächlich lassen sich in der Praxis nicht alle Forderungen erfüllen, vor allem dann nicht, wenn es sich um universelle Primer handelt, bei denen noch andere Kriterien hinzutreten (s.u.). Insofern kann als reduzierter Kriterienkatalog sowohl 
hinsichtlich der Primer-Dimer-Bildung als auch der Bildung von Hairpins Folgendes gelten:

- Vermeiden von mehr als einer Bindung innerhalb der ersten 3 Nucleotide des 3 '-Endes.

- Maximaler $\Delta \mathrm{G}-\mathrm{Wert}$ von $8,5 \mathrm{kcal} / \mathrm{mol}$.

\subsubsection{Kontaminationen und Gemische}

\subsubsection{Kontamination von Chemikalien und Reaktionsgefäßen}

Die ansatzfreie Identifizierung von DNA-Spuren bedingt den Einsatz universeller Primersysteme. Der hohe analytische Wert gut gewählter universeller Primer birgt zugleich ein Problem, das im Umgang mit fast allen Organismen besondere Beachtung verdient. Universelle Primer sind zwar theoretisch in der Lage, ein ganzes Spektrum vorher unbekannter Organismen zu amplifizieren, sind aber damit zugleich außerstande gegen eventuelle Kontaminationen zu diskriminieren. Potentielle Kontaminatoren wie Mensch (z.B. als Bearbeiter) oder Rind (z.B. in Form von unreinem BSA) können zwar durch diskriminierendes Primerdesign ausgeschlossen werden, sind dann aber auch nicht mehr nachweisbar.

Menschliche Kontaminationen in Reaktionsgefäßen treten gemäß früherer Untersuchungen (Schmidt et al. 1995) in nicht unerheblichem Maße auf. Da der Mensch als Fokusorganismus im Rahmen von archäometrischen Analysen von Sachüberresten nur in Ausnahmefällen eine Rolle spielen dürfte, wäre es vorteilhaft, ihn ganz aus der Analyse herausnehmen zu können. Die Untersuchung konnte zeigen, daß dies durch gezieltes Primerdesigns leicht möglich ist. Im Unterschied dazu zählen Rinder in Europa zu den wichtigsten historischen Nutztieren und spielen in vielen traditionellen Herstellungsverfahren eine wesentliche Rolle. So wäre es sinnlos, sie als archäometrischen Untersuchungsgegenstand generell auszuschließen. Dies sollte dennoch immer dann geschehen, wenn Rinder als Fokustiere nicht in Betracht kommen. 
Für Rinder müssen ebenso wie für Menschen andere Kriterien gefunden werden, um authentische Sequenzen von Kontaminationen $\mathrm{zu}$ unterscheiden. Hier bieten sich individualisierbare Systeme wie STRs (Hummel et al. 1999a, Hummel et al. 2000) oder die hypervariablen Abschnitte der mitochondrialen Kontrollregion zur Untersuchung parallel mit den konservierten loci an.

Am Beispiel des Berliner Manuskripts konnte gezeigt werden, wie STRGenotypisierungen in der Lage sind, einen singulären Kontaminanten (in diesem Fall einen Menschen) zu rekonstruieren, nachdem konservative mitochondriale Sequenzen alleine zu keiner Aussage über die Authentizität führen konnten (Kap. 5.7.1, S. 81f).

Beachtenswert ist die Tatsache, daß Extraktionskontrollen häufiger positive Resultate aufweisen als PCR-Leerkontrollen. Dies ist daruf zurückzuführen, daß Extraktionskontrollen vergleichbar mehreren Chemikalien und Reaktionsgefäßen, die Kontaminationen übertragen können, ausgesetzt sind als PCR-Kontrollen. Die Kontaminationen durch Schaf, Ziege und Schwein sind möglicherweise auf Kreuzkontaminationen zurückzuführen. Während Schaf, Ziege und Schwein mehrfach im Labor extrahiert und amplifiziert wurden, war Katze niemals Untersuchungsgegenstand. Die beiden Sequenzen von Felis catus, die Im Laufe dieser Untersuchung festgestellt wurden, müssen folglich von Bearbeitern oder über Gebrauchsgegenstände importiert worden sein.

Allgemein ist für die bevorzugte Verwendung von semiuniversellen Primern zu plädieren. Semiuniverselle Primer werden als solche definiert, die für bestimmte taxonomische Einheiten, wie z.B. Gattungen oder Familien, konzipiert sind. Im Vergleich dazu sind universelle Primer konservativer und amplifizieren eine größere Bandbreite von Taxa. Die Übergänge zwischen semiuniversellen und universellen Primern sind allerdings fließend und die Unterscheidung nur eine pragmatische. 
Eine besondere Schwierigkeit ist bei der Analyse von Pflanzen-DNA zu erwarten, da sie in der Regel über die Luft mobil ist. Ohne geschlossene Reinraumbedingungen ist demnach vermehrt mit Eintrag von Pflanzen-DNA zu rechnen. Aber auch unter extremen Reinraumbedingungen ist ein Eintrag von jeglicher DNA über den Produktions- und Versandweg nicht auszuschließen.

Die Ergebnisse in 5.7.2 (S. 83ff) verdeutlichen, daß Pflanzen-Sequenzen ein Spiegel des jeweiligen Labor-Standorts sein können. Die Kontaminationsrate entsprach darüber hinaus den erwarteten saisonalen Schwanken und stieg in Frühjahr und Sommer gegenüber der Winterzeit.

\subsubsection{Artefakte als Gemische}

Organische Sachüberreste oder sekundäre Biomaterialien haben gegenüber primären Biomaterialien, wie Skeletten, zwei Nachteile. Zum einen handelt es sich bei organischen Resten von Artefakten in der Regel um Spuren, die während des Herstellungsprozesses künstlich degradiert wurden, zum anderen bestehen Sachüberreste sehr häufig aus Mischungen unterschiedlicher Materialien. Dies sei am Beispiel eines traditionell hergestellten Kodexes verdeutlicht. Während die beschriebenen Pergamentseiten aus Schafshaut gefertigt sein könnten, könnte der Einband aus Schweinsleder gemacht sein, das mit pflanzlichen Tanninen gegerbt wurde. Ein weiteres pflanzliches Öl könnte zum Schutz des Leders auf dieses aufgetragen worden sein. Die Leimung der Seiten und des Buchrückens wiederum könnte mit Knochenleim aus mindestens einer Spezies (z.B. Ziege), vielleicht aber auch aus einem Gemisch aus Knochen- und Pergamentabfall (z.B. Ziege, Huhn und Schaf) vorgenommen worden sein. Bereits jetzt besteht das Buch aus einer genetischen Vielfalt von fünf bis sieben Organismen. Organische Bindemittel in Tinten und Farben oder nachträgliche Reparaturen und restauratorische Eingriffe mit organischem Material sind dabei noch nicht berücksichtigt. 
Im Rahmen der Untersuchungen traten häufig multiple Sequenzen auf. Dieses Phänomen ist zu beobachten, wenn mehrere Organismen in einer PCR coamplifiziert werden und keiner davon mengenmäßig deutlich vorherrscht. Ursache für multiple Sequenzen können Kontaminationen sein, die zusätzlich zur endogenen DNA der Probe in der Reaktion vorkommen oder endogene Gemische verschiedener Organismen. Bei der direkten Sequenzierung ist es bei mehr oder weniger ausgewogenem Verhältnis der Competitoren nicht möglich, auf die Sequenzen zurückzuschließen. In diesem Fall müßten PCR-Produkte kloniert und die Klone einzeln sequenziert werden (Krings et al. 1997, 1999, Greenwood et al. 1999).

Der PCR-RFLP bietet eine methodische Alternative. Da die Methode die Signale polymorpher Organismen voneinander trennt und nicht wie bei der direkten DNASequenzierung übereinanderlegt, können zumindest Organismen, deren Polymorphismen bekannt sind, identifiziert werden. Dies zeigt das forensische Beispiel von der gemischten Schaf-Rind-Spur. Für komplexere Fragestellungen und zur exakten Identifizierung einer individuellen Sequenz bleibt allerdings nur das aufwendige Verfahren der Sequenzierung von klonierten PCR-Produkten.

\subsubsection{Authentifizierung von aDNA-Daten}

Nicht immer ist es möglich, den direkten Nachweis alter DNA ohne enzymatische Amplifikationsschritte zu führen, wie dies aus 3.000 Jahre alten Knochen und einer in Ethanol eingelegten Mißgeburt gelungen ist (Hummel et al. 1999b). Nicht so verhält es sich, wenn sich PCR-Schritte zwischen Extraktion und Analyse befinden. Die Kriterien, die in der Literatur für die Authentifizierung alter DNADaten gefordert werden, treiben bisweilen wundersame Blüten (z.B. Ward \& Stringer 1997). Unbestritten ist, daß in Anbetracht der Kontaminationsanfälligkeit der PCR verbindliche Authentizitätskriterien vorhanden sein müssen. Dabei sind aus wissenschaftstheoretischen Gründen Verifizierungen der Ergebnisse einer Methode (aDNA) durch die einer anderen (Proteinchemie) (vgl. Krings et al. 1997, 
1999, Poinar et al. 1996, Poinar \& Stankiewicz 1999) nicht möglich. Wesentliches Kriterium ist, wie in jeder Naturwissenschaft, das der Reproduzierbarkeit eines Resultats in einem unabhängigen Versuch. Dabei ist das Kriterium der Unabhängigkeit eines Versuchs nicht damit zu erfüllen, daß eine Probe in ein anderes Labor transportiert wird. Vielmehr ist es hinreichend erfüllt durch ein standardisiertes Versuchsdesign unter Verwendung entsprechender Kontrollen, die die Existenz systematischer Fehler bei allen Versuchen ausschließen. Eine systematische Kontamination einer Probe würde in einem zweiten Labor nur ein zweites kontaminiertes Ergebnis liefern. Insofern gilt es, systematische Fehler durch Kontrollen zu erkennen und auszuschließen und Kriterien zu finden, die die Authentizität von Ergebnissen anhand der Ergebnisse selbst überprüfen, unabhängig von Ort und Untersucher, d.h. es muß ein objektives Verfahren gefunden werden. Im Folgenden soll für STR-Alleldaten und mitochondrialer Sequenzdaten ein Versuch unternommen werden.

\subsubsection{Short Tandem Repeats}

\subsection{Extraktions- und Amplifikationsleerkontrollen}

Im Spiegel der Erkenntnis, daß Einmalwaren bereits produktionsseitig kontaminiert sein können (Schmidt et al. 1995), ist es nicht verwunderlich, daß Amplifikationskontrollen bisweilen positiv sein können. Sollten Alledeterminierungen von Amplifikationsleerkontrollen mit Probenalleldeterminierungen übereinstimmen, dann müssen die betroffenen Proben für die Genotypisierung ausgeschlossen werden, bis das Phänomen beseitigt ist. Sollten Alleldeterminationen von Extraktionskontrollen positiv ausfallen, so gilt es entsprechende Alleldeterminationen von Proben auszuschließen. Insgesamt gilt für individualisierbare Daten, daß bei positiven Resultaten von Extraktions- und Amplifikationsleerkontrollen nicht die komplette Amplifikation oder Extraktion verworfen werden muß, sondern die Kontamination mit Probendaten verglichen werden kann (vgl. Hummel et al. 
2000). Nur wenn Anzeichen der Übereinstimmung von Kontamination und Probenergebnis zu bemerken sind, müssen diese Ergebnisse ausgeschlossen werden.

\subsection{Alleldeterminierung}

Die Annahme, daß das Auftreten und die Intensität eines tatsächlich in einem Organismus vorhandenen Allels wahrscheinlicher ist als das Auftreten eines unsystematischen Artefakts führt zu folgender Vorgehensweise:

Bei der Alleldeterminierung werden jeweils die beiden stärksten Signale im Allelbereich aufgenommen. Im Falle der Anwesenheit eines dritten oder vierten Signals mit nur wenig geringerer Intensität werden diese in Klammern aufgenommen, solange es sich nicht um einen offensichtlichen Fall von Stotterbande handelt. Im Falle eines prädominierenden Signals (4-fache peakheight im Vergleich zum zweitstärksten Signal) wird nur dieses aufgenommen. Bei nur 3- bis 4-facher peakheight des stärksten Signals zum zweitstärksten wurde das zweitstärkste Signal in Klammern aufgenommen. Desweiteren besteht die Möglichkeit, daß das zweitstärkste Signal eine offensichtliche Stotterbande eines sehr dominanten stärksten Signals ist, während das eigentliche zweite Allel als drittstärkstes Signal erscheint. In diesem Fall werden stärkstes und drittstärkstes Allel aufgenommen.

\subsection{Genotypisierung}

In der Regel wurden bei vorliegender Untersuchung mindestens zwei DNAExtraktionen vorgenommen, von denen jeweils zwei Amplifikationen durchgeführt wurden (Schema: 2 á 2). Hieraus ergaben sich bei erfolgreicher Amplifikation vier Alleldeterminationen. Allele, die dreimal von vier vorkamen, wurden zur Erstellung des Genotyps verwendet. Allele, die zweimal von vier erschienen, wurden in Klammern aufgenommen.

Das Schema 2 á 2 erwies sich als sehr praktikabel. Als Mindestanforderung zur Authentifizierung von STR-Daten wird das Schema 1 á $2+1$ á 1 vorgeschlagen, 
unter der Voraussetzung, daß sich die Allele in allen drei Reaktionen reproduzieren lassen.

\subsubsection{DNA-Sequenzen}

\subsection{Extraktions- und Amplifikationsleerkontrollen}

Im Falle von positiven Extraktions- und Amplifikationsleerkontrollen sind alle Sequenzen gleichen Ergebnisses auszuschließen. Da derselbe Kontaminant aufgrund unterschiedlicher Sequenzartefakte zu leicht unterschiedlichen Sequenzen führen kann, sind auch sehr ähnliche Sequenzen mit nur geringen Abweichungen von der Kontamination auszuschließen, solange die Abweichungen nicht durch

unabhängige Versuche bestätigt werden. Im Falle taxonomischer Identifizierung mit (semi)universellen Primern betrifft der Ausschluß alle Ergebnisse gleicher Spezies (bei Pflanzen: gleichen Genus, Familie, Ordnung, etc.).

\subsection{Sequenzdeterminierung}

Auch für Sequenzdaten gilt das Schema 1 á $2+1$ á 1 (d.h. zwei Amplifikationen aus der ersten Extraktion und eine weitere aus der zweiten Extraktion) als Mindestanforderung. Dies genügt nur dann, wenn alle Daten dreifach reproduziert wurden. Da wegen Dekompositionsdefekten (z.B. Modifizierung von Basen durch Deaminierung oder Depurinierung) oder durch Polymerase induzierte Fehler nur selten alle Basen dreifach reproduziert werden können, kann in vielen Fällen zwar nicht die exakte Sequenz, aber die Spezies bestimmt werden, da diese sich nicht unbedingt aufgrund einiger weniger Nucleotidvariationen ändern würde. Um die exakte Sequenz bestimmen zu können (etwa für phylogenetische Berechnungen), wurde zunächst angenommen, daß solange weitere Sequenzen zu bestimmen sind, bis jedes Nucleotid in mindestens 75\% aller Fälle reproduziert wurde. Folgende 
Aufstellung verdeutlicht beispielhaft, welche Ergebnisse zu Sequenzbestimmungen gemäß der aufgestellten Richtlinien herangezogen werden können:

3 von $3(100 \%)$;

3 von $4(75 \%), 4$ von $5(80 \%), \ldots, n-1$ von $n$;

8 von $10(80 \%)$;

9 von 12 (75\%), 12 von $16(75 \%), 15$ von $20(75 \%)$;

Die nicht kursiven Beispiele erscheinen unter der Annahme, daß biochemische Modifikationen von Basen bzw. Sequenzartefakte unsystematisch auftreten, a priori als akzeptabel. Die kursiven Beispiele, bei denen Abweichungen zwei bis fünfmal stattgefunden haben, führen $\mathrm{zu}$ folgenden Überlegungen: Tritt das Ereignis einer Substitution an einem Nucleotid-locus einmal auf, dann ist die Wahrscheinlichkeit für dieses Ereignis an diesem Ort bei einer Sequenz von 100bp gleich 1/100. Bei 8 von 10 Reproduktionen hat eine Base sich allerdings bereits zweimal nicht reproduzieren lassen. Das Ereignis tritt mit einer Wahrscheinlichkeit von 1/10.000 zufällig auf. Das Ereignis 15 von 20 tritt (obwohl es sich wie z.B. bei 3 von 4 um 75\% Reproduktionshäufigkeit handelt) bei einer 100bp langen Sequenz mit einer Wahrscheinlichkeit von $10^{-6}$ auf. Die Wahrscheinlichkeit, daß es sich hier noch um einen unsystematischen Zufall handelt, ist folglich sehr gering.

Die vorangegangen Simulationen zeigen, daß die Authentifizierung von Sequenzen nicht nach dem Kriterium der Reproduktionsrate (in Prozenten) erfolgen sollte (wie zunächst angenommen), sondern vielmehr nach Berechnungen der Wahrscheinlichkeit einer zufälligen Basensubstitution, die wiederum in Abhängigkeit von der Länge des sequenzierten Fragments steht. Bei einer Sequenzlänge (ohne Primer) von $b$ ist

$$
\mathrm{f}_{\text {mod }}=\mathrm{N} / \mathrm{b}^{\mathrm{n}}
$$

wobei n die Anzahl der Wiederholungen des Ereignisses Basensubstitution und N die Anzahl der verglichenen Sequenzen ist.

So ist z.B. bei einer Sequenz $(\mathrm{N}=1)$ von 100bp $(\mathrm{b}=100)$ die Wahrscheinlichkeit, daß eine zufällige Basensubstitution entsteht $10^{-2}$. Die Wahrscheinlichkeit, daß dieses Ereignis bei zehn Sequenzen derselben Probe einmal entsteht, ist $10 / 100^{1}=10^{-1}$. Die Wahrscheinlichkeit, daß es bei zehn Sequenzen zweimal ent- 
steht, ist $10 / 100^{2}=10^{-2}$. Am Beispiel des Pergaments aus Haut von Camelus bactrianus (vgl. Abb. 16, Kap. 5.2.1.2, S. 63ff) sei dies verdeutlicht: Ohne Primer ist die Sequenz 77bp lang. An Position 85 findet sich bei 2 von 8 Sequenzen eine Abweichungen von der Majorität, G statt A. Die Wahrscheinlichkeit der Zufälligkeit einer zweifachen Basensubstitution an derselben Stelle ist folglich:

$$
\mathrm{f}_{\text {mod }}=8 / 77^{2}=1,35 \times 10^{-3} \text {. }
$$

Bei einer 500bp langen Sequenz wäre die Wahrscheinlichkeit der Zufälligkeit desselben Ereignisses

$$
\mathrm{f}_{\text {mod }}=8 / 500^{2}=3,2 \times 10^{-5} \text {; }
$$

d.h. die Wahrscheinlichkeit, daß es sich um ein zufälliges Ereignis handelt, ist bei der längeren Sequenz geringer als bei der kürzeren. Welchen absoluten Wert $f_{\text {mod }}$ haben darf, ist vom Untersucher selbst festzulegen und bedarf weiterer empirischer Erfahrungen.

Es gilt zu berücksichtigen, ob der $\mathrm{f}_{\text {mod }}$-Wert von Sequenzen, die direkt aus PCRProdukten oder aus klonierten PCR-Produkten sequenziert wurden, errechnet wird. Bei ersteren werden unsystematische Nucleotidsubstitutionen nur dann feststellbar sein, wenn sie in frühen Zyklen der PCR geschehen sind. Auch bei klonierten PCR-Produkten ist die Häufigkeit des Ereignisses Substitution unter den Klonen im Zusammenhang mit dem Zeitpunkt seines Auftretens in der PCR-Reaktion zu sehen. Jedoch werden durch das Aufteilen der Molekülpopulation auf Klone auch seltenere Ereignisse, die bei der direkten Sequenzierung aufgrund von Nachweisgrenzen gar nicht oder als „Unterpeaks“ erscheinen, eindeutig detektierbar.

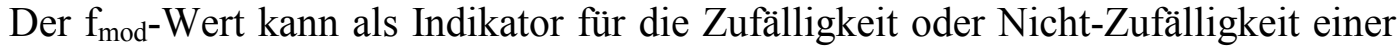
Nucleotidabweichung innerhalb einer definierten Sequenz genommen werden. Seinen praktischen Nutzen wird er in der Empirie erweisen müssen.

\subsection{Exkurs: $f_{\text {mod }}$ Berechnungen klonierter Sequenzdaten}

Die vorangegangen Überlegungen sollen an einem Beispiel aus der Literatur (Greenwood et al. 1999) exemplifiziert werden. Die folgenden Berechnungen sind zwar von keiner weiteren Relevanz für die in dieser Arbeit präsentierten Daten, sollen aber im Sinne einer differen- 
zierten Betrachtung dem weiteren Verständnis von aDNA-Sequenzen dienen.

Die Positionen beziehen sich auf Klone einer DNA-Sequenz aus ca. 14.000 Jahre altem Mammut-Dentin, wie sie in der genannten Veröffentlichung unter „Figure 2“ dargestellt sind.

1.An der Stelle ,a“ des vWF-Gens befindet sich bei 14 von 30 sequenzierten Klonen ein $\mathrm{T}$, bei 15 ein $\mathrm{C}$ und bei einem ein A. Die errechneten $\mathrm{f}_{\text {mod }}$-Wahrscheinlichkeiten für die Zufälligkeit der Ereignisse lauten

für T: $30 / 56^{14}=1,00575 \times 10^{-23}$

für C: $30 / 56^{15}=1,8 \times 10^{-25}$

für A: $30 / 56^{1}=0,54$

Die Werte für $\mathrm{T}$ und $\mathrm{C}$ sind so niedrig, daß die Zufälligkeit ihrer Existenz ausgeschlossen werden kann. Beide müssen eine tatsächliche Ursache haben oder aus einem systematischen Fehler entstehen. Die Autoren argumentieren entsprechend, daß $\mathrm{C}$ und $\mathrm{T}$ zwei Allele des vWFGens darstellen. Die $f_{\text {mod }}$-Wahrscheinlichkeit des Zufalls, daß an einer Stelle von 30 Klonen der Länge 56bp eine Substitution (hier A statt C oder T) stattfindet ist mit $f_{\text {mod }}=0,54 \mathrm{sehr}$ hoch. Insofern muß keine systematische Ursache, sondern vielmehr ein einmaliger Fall von Misinkorporation durch die Polymerase hierfür angenommen werden.

2. Drei Basenpaare vor der Stelle ,„a “ befindet sich bei 30 Klonen 28 mal ein $C$ und zweimal ein $T$. Die errechneten $f_{\text {mod }}$ Wahrscheinlichkeiten für die Zufälligkeit des Ereignisses $T$ statt $C^{11}$ ist:

$$
\mathrm{f}_{\text {mod }}=30 / 56^{2}=0,957 \times 10^{-3}
$$

Der Wert kommt demjenigen der T-Substitution der Trampeltiersequenz nahe, bei der es sich mit Sicherheit um ein Artefakt handelt. Folglich sind $\mathrm{f}_{\text {mod }}$-Werte mit dem Exponenten „-3“ aus empirischen Gründen noch hinreichend, um die Zufälligkeit eines Ereignisses anzunehmen.

3. Acht Basenpaare nach der Stelle „a“ finden sich unter 30 Klonen vier mit der abweichenden Base T:

$$
\mathrm{f}_{\text {mod }}=30 / 56^{4}=3,05 \times 10^{-6}
$$

In diesem Fall sollte der Wert nicht mehr für die Zufälligkeit des Ereignisses sprechen. Vielmehr muß eine systematische Ursache angenommen werden. Da die humane Sequenz an dieser Stelle ein T aufweist, handelt es sich an dieser Stelle möglicherweise um menschliche

${ }^{11}$ Tatsächlich berücksichtigt der $\mathrm{f}_{\text {mod }}$-Wert nicht, um welche Basensubstitution es sich im einzelnen handelt, sondern berrechnet nur das generelle Ereignis einer Abweichung. 
Kontaminationen. Gegen diese Annahme spricht die Tatsache, daß an anderen Stellen derselben Klone keine spezifisch menschlichen Basenabweichungen festgestellt wurden. Ohne Zuhilfenahme von molekulargenetischen Konstrukten, wie dem des „polymerase jumping“ wäre ein solches Mosaik nicht zu erklären. Es bleibt dahingestellt, welche Mechanismen zu reproduzierbaren Nucleotidsubstitutionen führen können. Das gezeigt Beispiel soll aber verdeutlichen, daß der $\mathrm{f}_{\text {mod }}$-Wert ein geeignetes Werkzeug darstellt, um auf ungewöhnliche Abweichungen aufmerksam zu machen.

4. Die Positionen 7 und 9 des A2AB-Gen haben für das Ereignis $\mathrm{T}$ statt $C$, bezogen auf die zweite Amplifikation des zweiten Extrakts einen $\mathrm{f}_{\text {mod }}$-Wert von $9 / 57^{8}=8,076 \times 10^{-14}$.

Bezogen auf alle drei Amplifikationen des A2AB-Gens ergibt $f_{\text {mod }}$ $=26 / 57^{8}=2,33 \times 10^{-13}$.

Der $\mathrm{f}_{\text {mod }}$-Wert zeigt an, daß in der zweiten Amplifikation des zweiten Extrakts eine systematischer Fehler geschehen ist, der wahrscheinlich auf eine Misinkorporation der Polymerase in frühen Zyklen der PCR zurückzuführen ist. Insofern muß diese Amplifikation wiederholt oder zumindest die entsprechende Nucleotidposition von der Sequenzdeterminierung ausgeschlossen werden. Entsprechendes gilt für alle von den Autoren mit „*“ gekennzeichneten Stellen, aber nur dann, wenn das Ereignis in einer einzigen PCR-Reaktion zu beobachten ist. Auffällig an den mit Stern gekennzeichneten Stellen ist die Tatsache, daß in fünf von zehn Fällen die Artefakt-Substitution in erster Linie in Klonen einer PCR zu beobachten sind, aber an derselben Stelle jeweils einmal auch in anderen Amplifikationen zu finden sind. Als Ursachen hierfür können entweder Hintergrund-Kontaminationen durch fremde Moleküle oder präferentielle DNA-Degradierungspositionen, die zu vermehrter polymeraseinduzierter Artefaktbildung führen, angenommen werden. 


\subsection{Zusammenfassende Bewertung und Perspektiven}

Ziel der vorliegenden Untersuchung war es, archäometrische Fragestellungen an Sachüberreste mit molekulargenetischen Methoden zu beantworten. Dabei wurden methodenbedingt nur die Sachüberreste berücksichtigt, die entweder aus organischem Material bestehen oder denen organisches Material anhaftete. Sachüberreste wurden danach als diejenigen Materialien definiert, deren organische Fraktionen zusätzlich zu diagenetischen Effekten, durch ein gezieltes Prozessieren durch den Menschen modifiziert wurden.

\subsubsection{Extraktion}

Die unterschiedlichen Materialien dieser Untersuchung erforderten jeweils angepaßte Methoden der DNA-Extraktion, wobei bei der Isolation von degradierter DNA stets ein Kompromiß zwischen Qualität der Aufreinigung und Verlust an DNA gefunden werden mußte. Bei Sachüberresten tritt der Umstand hinzu, daß viele der in Materialgruppen zusammengefaßten Proben zugleich ein individuelles physikalisch-chemisches „Profil“" besitzen, das durch unterschiedliche Fertigungstechniken bzw. eine einmalige Erhaltungshistorie entstanden ist. Trotz der hohen Variabilität der chemischen Zusammensetzung von Einzelstücken galt es, Protokolle zu finden, die für ganze Materialgruppen als praktikable Basis dienen und im Einzelfall gegebenenfalls angepasst werden können.

Für bodengelagerte Knochen hat sich die Phenol/Chloroform-Methode in vielen Zusammenhängen bereits als geeignet erwiesen (Hummel et al. 1995, Krings et al. 1997, Schultes et al. 1999, Schmerer et al. 1999) und wurde auch in dieser Untersuchung für tierliche Knochen der Bronzezeit (850-500 v. Chr.) erfolgreich angewendet (Kap. 5.1.2, S. 58ff). Die Phenol/Chloroform-Extraktion ist das Mittel der Wahl, um phenolische Geopolymere wie Humin- und Fulvosäuren, die die enzymatische Amplifikation inhibieren, von der DNA zu trennen. Auch Leder ist durch die Gerbung mit Polyphenolen kontaminiert, so daß die Phenol/ChloroformExtraktion auch hier zum Einsatz kam. Für Buchleder konnte gezeigt werden, daß 
die Phenol/Chloroform-Methode in der Lage ist, Inhibitoren $\mathrm{zu}$ entfernen und DNA quantitativ zu isolieren (Kap. 5.2.3; S. 70). Bei archäologischen Ledern treten zu den Polyphenolen der Gerbstoffe noch die des Bodens hinzu, weswegen die Aufreinigung nur selten gelang. Nur wenn mehrere Phenolschritte erfolgten, konnten die Inhibitoren entfernt werden. In diesen Fällen war aber auch keine DNA mehr nachweisbar (Kap. 5.2.4, S. 71).

Bei den Inhaltsresten der aztekischen Behälter (Kap. 5.4.2, S. 75ff) handelte es sich in der Regel um eine dunkle harzige Masse und bereits die Lyse dieser Stoffe war mit herkömmlichen Extraktionspuffern nicht zu bewerkstelligen. Eine Kombination aus einem Guanidinthiozyanatpuffer und anschließender Phenol/Chloroform-Extraktion brachte hierfür die Lösung. Sowohl die starken Inhibitoren wurden entfernt als auch die endogene DNA aufgeschlossen. Mit der Guanidinthiozyanat-Phenol/Chloroform-Methode gelang es sogar, die Inhibitoren aus den vermeintlichen Nachgeburtsbestattungen, die fast vollständig aus Erdreich bestanden, aufzureinigen (Kap. 5.4.3, S. 77f). Für Leime und Bindemittel historischer Werkstoffe wurde derselbe Effekt durch die Kombination eines CTABPuffers mit der Phenol/Chloroform-Extraktion erreicht (Kap. 5.3.2, S. 73f).

Proben wie Pergamente, die nur geringfügig mit polymeren Abbauprodukten belastet sind, können ohne größeren Aufwand mit Schnellextraktionen wie der Chelexmethode behandelt werden.

Folgendes Fazit kann aus den Erfahrungen mit unterschiedlichen Extraktionsmethoden gezogen werden. Kommerzielle Kits sind in der Lage, geringe Mengen an Inhibitoren effektiv aufzureinigen. Jedoch geht die Reinheit auf Kosten der Ausbeute. Viele Sachüberreste zeichnen sich allerdings durch größere Mengen an Inhibitoren aus, da durch den Herstellungsprozess oder die Bodenlagerung Substanzen eingeführt werden, die antimikrobiell und damit präservierend wirken. Präservierende Substanzen - hierzu zählen auch die Huminstoffe des Bodens - können als Inhibitoren auftreten. Die Aufreinigung großer Mengen an Inhibitoren kann durch kommerzielle Kits nicht mehr bewerkstelligt werden. Insofern sind die meisten Untersuchungen an Sachüberresten auf effektivere Aufreinigungsmethoden, eventuell sogar auf die Kombination mehrerer Protokolle angewiesen. Mit 
den vorliegenden Verfahren wurden Basisprotokolle entwickelt, die bei intensiverer Beschäftigung mit einzelnen Materialgruppen oder individuellen Funden an spezifische Anforderungen angepaßt werden können.

\subsubsection{DNA-Erhalt}

Neben das Liege- bzw. Lagerungsmilieu treten bei Sachüberresten die Herstellungsprozesse als Einflußfaktoren auf den DNA-Erhalt. Hinsichtlich des DNAErhalts gilt es bei Sachüberresten zwei Gruppen zu unterscheiden: Zum einen diejenigen Materialien, bei denen der Herstellungsprozess maßgeblich an DNAErhalt bzw.-Degradierung beteiligt ist und zum anderen diejenigen, bei denen das Liegemilieu bzw. die Überdauerungsgeschichte den Hauptfaktor darstellt.

Bei fast allen Sachüberresten (Pergamenten, Ledern, Leimen, Bindemitteln, Ölen und Inhaltsresten) ist der Verarbeitungs- bzw. der Herstellungsprozess der für den DNA-Erhalt kritische Faktor. Während z.B. die Verarbeitung von Häuten bei der historischen Pergamentherstellung aufgrund von Äscherung und Trocknung einen positiven Einfluß auf die DNA hat, zerstört das Gerben die DNA der Haut. Die Herstellung von Leimen besteht in der Regel aus der thermischen Auflösung von biologischen Kollagenstrukturen. Für die DNA ist dabei entscheidend, wie lange sie den Temperaturen ausgesetzt ist. Es ist anzunehmen, daß die historischen Rezepte diesbezüglich variierten. Abgesehen von hohen Temperaturen sind bei der klassischen Herstellung von Leimen aus Kollagengeweben keine weiteren negativen Faktoren für den DNA-Erhalt zu erwarten. Insofern sind die Erhaltungsaussichten von DNA in Leimen dann gut, wenn der Leim nicht bei zu hohen Temperaturen hergestellt wurde. Dasselbe gilt für die Inhaltsreste von Behältern, wenn es sich dabei um gekochte Nahrung handelt.

Zusammenfassend kann festgestellt werden, daß beim Prozessieren der Materialien zusätzlich zu den basalen Faktoren Temperatur, Feuchtigkeit und pH-Wert komplexere chemische Abläufe durch Zusatzstoffe (z.B. Kalk bei Häuten, Gerbstoffe bei Ledern, Gewürze bei Inhaltsstoffen, Metalle bei Farbstoffen, etc.) in 
Betracht zu ziehen sind. Die Rolle von Zusatzstoffen des Herstellungsprozesses gilt es im einzelnen zu überblicken und bei der DNA-Isolierung zu berücksichtigen.

Zusätzlich zu den Prozessen der Materialerzeugung treten bei Sachüberresten die Wirkungen der Lagerung und des Liegemilieus hinzu. Hier gilt es zu unterscheiden, ob es sich um archäologische, bodengelagerte Funde oder um Gegenstände handelt, die an der Oberfläche die Zeit überdauerten. Für erstere gelten, wie für alle archäologischen Funde, die Mechanismen, wie sie bereits für bodengelagerte Skelettelemente beschrieben wurden (Burger et al. 1997, 1999). Organik, die nicht aus einem archäologischen Zusammenhang stammt, muß bereits bei der Herstellung des jeweiligen Werkstoffes oder Gegenstands protektive Behandlungen erfahren haben, um die Zeit überdauern zu können. Organische Stoffe aller Art würden ohne speziellen Schutz die aggressive Umgebung des Sauerstoffs und die Aktivität von Mikrofauna und -flora nicht überstehen. Das bedeutet, daß an der Luft, ebenso wie im Boden, bereits eine Präselektion stattfindet; Objekte, die erhalten bleiben, zeugen allein durch ihre Existenz von günstigen Erhaltungsbedingungen. Ob günstige Erhaltungsbedingungen für die Morphologie sich mit denen für DNA decken, muß im Einzelfall geklärt werden ${ }^{12}$. Entscheidend ist, ob die DNA in eine Struktur eingebettet ist, die sie vor aggressiven Umweltfaktoren wie Sauerstoff, Wasser, UV-Strahlung, freien Radikalen und Mikroorganismen schützt. Bei organischen Gebrauchsspuren an Steinwerkzeugen, Bindemitteln in Felsbildern und den meisten archäologischen Kleinfunden ist dies definitiv nicht der Fall. Deswegen konnte aus diesen Materialien keine DNA gewonnen werden und es bestehen darauf auch in Zukunft nur schlechte Aussichten.

\footnotetext{
${ }^{12}$ Kollagenfibrillen in Pergamenten und Ledern benötigen beispielsweise zur Aufrechterhaltung ihrer Struktur eine bestimmte Menge an Feuchtigkeit (Reed 1972); ohne diese wird das Material brüchig und zerfällt. Bei DNA jedoch führt Feuchtigkeit zu hydrolytischen und vor allem oxidativen Schäden.
} 


\subsubsection{Datenauswertung}

\subsubsection{Speziesidentifizierung von Tieren durch mtDNA-Sequenzierung und PCR-RFLP}

In der Literatur wurde der locus der 12SrRNA kodierenden DNA für phylogenetische Untersuchungen sowohl auf dem Niveau der Familie als auch der Genera und Spezies herangezogen (Hillis et al. 1996: 235, Simon et al. 1990). Die in der vorliegenden Untersuchung verwendeten Primersysteme rR4ab und rR4ac erwiesen sich zur Speziesidentifikation von Vertebraten als geeignet. Vor dem Hintergrund der Erfahrungen dieser Untersuchung kann festgestellt werden, daß der locus für taxonomische Untersuchungen auf dem Niveau der Spezies sehr gut, für populationsgenetische Untersuchungen aber nicht geeignet ist. Von der weiteren Anwendung der Primersysteme rR4 wird dennoch abgeraten, da die Primer aufgrund fehlender mismatches zum Menschen für die Spurenanalytik nicht geeignet sind.

Die Variabilität innerhalb des Cytochrom B-Gens ist sehr unterschiedlich und am höchsten in der Nähe des 3'-Endes des codierenden Strangs. Unabhängig von der Position innerhalb des Gens konnte bei den verwendeten Primersystemen fast ausschließlich eine Variabilität hinsichtlich der Spezies festgestellt werden (vgl. Kocher et al. 1989). Auch das Cytochrom B-Gen wurde als geeigneter locus für die Speziesidentifikation durch Sequenzierung kurzer DNA-Abschnitte bestätigt.

Die Untersuchungen zeigten, daß bei allen Fragen der Speziesidentifikation darauf zu achten ist, die häufigsten Kontaminatoren Mensch und Rind durch diskriminierendes Primerdesign von der Amplifikation auszuschließen. Sollte dies aus inhaltlichen Gründen nicht möglich sein, kann die Authentizität einer Sequenz nur dann festgestellt werden, wenn die gefundenen Sequenzen von den Sequenzen der Kontaminanten reproduzierbar abweichen. Da die beiden loci Cytochrom B und 12SrRNA sich hinsichtlich der Spezies sehr konservativ verhalten, kann die Authentizität nur durch parallele Untersuchung anderer, variablerer Marker wie STRs oder Sequenzen der hypervariablen Region des Mitochondrions nachgewiesen werden. 


\subsubsection{Taxonomische Identifikation von Pflanzen durch cpDNA- Sequenzierung}

Die Substitutionsrate des rbcL-Gens läßt es -soweit die Angaben in der Literaturzu einem geeigneten locus für phylogenetische Fragestellungen auf dem FamilienNiveau werden (Soltis et al. 1990, Olmstead \& Palmer 1992, 1994). Die aDNASequenz des Salbeis im keltischen Beutel ließ sich sogar auf dem Genus-Niveau einordnen (Kap. 5.4.1; S. 74f). In der Regel sind jedoch nur Taxa höherer Ordnung zu diskriminieren. Die Resultate der vorkolumbischen Behälter aus Südamerika sprechen deutlich dafür, daß es sich bei dem rbcL-Gen um einen taxonomisch schwach auflösenden locus handelt. Der Vergleich der gefundenen alten Sequenzen mit Referenzsequenzen aus GenBank zeigte, daß Familien nicht diskriminiert werden können, sondern erst auf dem Niveau der Ordnung eine Identifikation stattfinden kann.

Dies wird am Beispiel des Sequenzvergleichs der Probe Ca1855 mit rezenten Sequenzen aus GenBank deutlich (vgl. Abb. 24, S. 75f). Die alte Probe steht zwar näher zur Spezies Tecoma stans aus der Familie der Bigoniaceae als zu anderen Spezies, da sich aber Spezies unterschiedlicher Familien im selben Cluster befinden, ist diese Aussage ohne Bedeutung. Die Aussage, die getroffen werden kann, ist die, daß die Sequenz der Probe IV Ca1885 zur Ordnung der Lamiales gehört. Die Verhältnisse bei der Probe IVCa 1905c sind analog (vgl. Abb. 25, S. 75f). Die nächst verwandten Sequenzen clustern nicht hinsichtlich der Spezies, des Genus oder der Familie, sondern der Ordnung (Zingiberales). Der Informationsgehalt verringert sich gegenüber der Aussage einer Familienzugehörigkeit beträchtlich. Die aus der Literatur bekannten Arbeiten zur taxonomischen Identifizierung von Pflanzen mithilfe des rbcL-locus (Golenberg et al. 1990, Soltis et al. 1990 und 1992, Poinar et al. 1998, Burger et al. 2000a) sollten hinsichtlich ihrere taxonomischen Interpretationen einer Revision unterzogen werden.

Tabelle 18 listet die Taxa auf, die in dieser Untersuchung mit den angegebenen Primern identifiziert wurden. 
Tabelle 18

\begin{tabular}{|c|c|c|c|}
\hline locus & Organimus & Taxon & Linie \\
\hline \multirow[t]{8}{*}{ 12S rRNA } & Odocoileus virginianus & Spezies & $\begin{array}{l}\text { Ruminantia (Subordnung); Pecora; Cer- } \\
\text { voidea; Cervidae; Odocoileinae; Odocoi- } \\
\text { leus; }\end{array}$ \\
\hline & Homo sapiens & Spezies & $\begin{array}{l}\text { Primates (Ordnung); Catarrhini; Homini- } \\
\text { dae; Homo }\end{array}$ \\
\hline & Oryctolagus cuniculus & Spezies & Leporidae (Familie); Oryctolagus; \\
\hline & Ovis aries & Spezies & $\begin{array}{l}\text { Ruminantia (Subordnung); Pecora; Bo- } \\
\text { voidea; Bovidae; Caprinae; Ovis }\end{array}$ \\
\hline & Felis catus & Spezies & Fissipedia (Subordnung); Felidae; Felis \\
\hline & Capra hircus & Spezies & $\begin{array}{l}\text { Ruminantia (Subordnung); Pecora; Bo- } \\
\text { voidea; Bovidae; Caprinae; Capra }\end{array}$ \\
\hline & Cyprinoidea & Spezies & $\begin{array}{l}\text { Cyprinoidea (Superfamilie); Cyprinidae; } \\
\text { Acheilognathinae; Rhodeus }\end{array}$ \\
\hline & Camelus bactrianus & Spezies & $\begin{array}{l}\text { Cetartiodactyla; Tylopoda (Subordnung); } \\
\text { Camelidae; Camelus; }\end{array}$ \\
\hline \multirow[t]{6}{*}{ Cytochrom B } & Capreolus capreolus & Spezies & $\begin{array}{l}\text { Ruminantia (Subordnung); Pecora; Cer- } \\
\text { voidea; Cervidae; Odocoileinae; Capreo- } \\
\text { lus; }\end{array}$ \\
\hline & Cervus elaphus & Spezies & $\begin{array}{l}\text { Ruminantia (Subordnung); Pecora; Cer- } \\
\text { voidea; Cervidae; Cervinae; Cervus; }\end{array}$ \\
\hline & Ovis aries & Spezies & $\begin{array}{l}\text { Ruminantia (Subordnung); Pecora; Bo- } \\
\text { voidea; Bovidae; Caprinae; Ovis }\end{array}$ \\
\hline & Capra hircus & Spezies & $\begin{array}{l}\text { Ruminantia (Subordnung); Pecora; Bo- } \\
\text { voidea; Bovidae; Caprinae; Capra }\end{array}$ \\
\hline & Felis catus & Spezies & Fissipedia (Subordnung); Felidae; Felis \\
\hline & Homo sapiens & Spezies & $\begin{array}{l}\text { Primates (Ordnung); Catarrhini; Homini- } \\
\text { dae; Homo }\end{array}$ \\
\hline \multirow[t]{5}{*}{ rbcL } & Salvia & Genus & Lamiales; Lamiaceae \\
\hline & Lamiales & Ordnung & - \\
\hline & Zingiberales & Ordnung & - \\
\hline & Pinaceae & Familie & Coniferales (Ordnung \\
\hline & Avena & Genus & Poales (Ordnung); Poaceae \\
\hline
\end{tabular}




\subsubsection{Individualidentifizierung durch STR-Genotypisierungen}

Im Rahmen dieser Untersuchung wurde zum ersten Mal tierliche MicrosatellitenDNA aus Sachüberresten isoliert und charakterisiert. Dies hat folgende Bedeutung für zukünftige Anwendungen:

1. Isolierte Fragmente eines Gegenstands können zugeordnet werden. Eine kulturgeschichtlich interessante Anwendung könnte die Methode z.B. bei den Fragmenten der Qumran-Rollen finden. Die religiösen Schriftrollen der Essener aus der judäischen Wüste sind inzwischen in Tausende von Fragmenten zerfallen, die mit klassischen kodikologischen Mitteln nicht mehr in ihren ursprünglichen Zusammenhang gebracht werden können (Reed \& Poole 1964, Parry \& Ricks 1996). STR-Genotypisierungen der Fragmente könnten sie nach Ziegenhäuten vorsortieren.

2. Mit der Isolierung nuklearer single-copy loci konnte gezeigt werden, daß nukleare Geninformationen aus Sachüberresten zu erhalten sind. Somit werden in Zukunft auch Analysen chromosomaler Merkmale (z.B. Fellfarbe, Krankheiten, etc.) verarbeiteter Tiere auf DNA-Ebene möglich sein.

3. Forensischen Anwendungen werden in Zukunft auf ein breiteres Materialspektrum mit molekulargenetischen Methoden zurückgreifen können. Die Methoden der STR-Analyse von Pergamenten sind auch auf andere prozessierte organische Materialien, wie etwa Pelze, anwendbar und können somit zur Beweisfindung beitragen.

\subsubsection{Populationsgenetische Perspektiven}

STR-Individualdaten aus Sachüberresten wurden mit Allelfrequenzen von modernen Rindern verglichen (vgl. Tab. 11, S. 68). Die Differenzen zwischen den modernen und historischen Allelfrequenzen sind so hoch, daß weitere populationsgenetische Analysen hinfällig waren. Nichtsdestotrotz besteht nun die Möglichkeit, 
historische Fundkomplexe untereinander und Einzelfunde mit diesen zu vergleichen. Die Analyse mitochondrialer DNA auf dem Cytochrom B-Gen und der 12SrRNA-DNA läßt sich für Sachüberreste auch auf Abschnitte des Mitochondrions übertragen, die eher von populationsgenetischem Interesse sind, wie etwa auf die D-loop-Region (vgl. Cooper \& Wayne 1998). Die populationsgenetischen Untersuchungen, die nun möglich geworden sind, werden zu der Beantwortung der Fragen führen, woher Fundstücke kommen, welche (Handels-) Wege sie genommen haben und zu welcher Tierpopulation bzw. Herde sie gehörten.

Neben archäometrisch-materialkundlichem besteht hierfür populationshistorisches Interesse. Auch außerhalb der Archäometrie sind die Anwendungsmöglichkeiten zahlreich. Spezies- bzw. Populationen identifizierende Systeme können in forensischen Zusammenhängen, z.B. bei illegalem Tierhandel oder Wilderei effektiv eingesetzt werden. Hier, aber auch in der Lebensmittelanalyse können die vorgestellten Protokolle der mtDNA-Sequenzierung und des PCR-RFLP gerade dann eingesetzt werden, wenn geringe Ausgangsmengen an stark degradierter DNA vorliegen. Der PCR-RFLP eignet sich darüber hinaus zur Identifizierung von Gemischen, was besonders für die Lebensmitteldiagnostik von Wert sein sollte. ${ }^{13}$

\subsubsection{Methodik}

Im methodischen Bereich der aDNA-Analytik können die vorgestellten Kriterien zum Design (semi)universeller Primer als Grundlage für sensiblere, effektivere und weniger kontaminationsbelastete Identifizierungsverfahren dienen. Auf der Basis der entwickelten Kriterien empfiehlt es sich, in Zukunft für einzelne Klassen bzw. Superfamilien weitere Primersysteme zu entwickeln. Für archäometrische Zwecke wäre es z.B. dienlich, mindestens ein Primersystem für Fische zu besitzen,

${ }^{13}$ Untersuchungen von Gemischen unterschiedlicher Organismen, die nicht mehr in diese Arbeit einfließen konnten, haben gezeigt, daß das vorgestellte PCR-RFLP-Protokoll (Kap. 4.4.1) Gemische im Verhältnis 1:20 eindeutig identifizieren kann. 
um Fischleime analysieren zu können. Im Bereich der taxonomischen Identifikation von Pflanzen gilt es zu prüfen, ob neue Erkenntnisse der Pflanzensystematik, wie z.B. die Verwendung von IT-spacer-Regionen und deren Sekundärstrukturen, für phylogenetische Analysen auch im Sinne von aDNA-Untersuchungen verwendet werden können.

Übersicht 2 faßt abschließend zusammen, welche Ergebnisse in Hinblick auf die in Kapitel 2 angesprochenen Nachfragen aus unterschiedlichen Wissenschaftsgebieten erzielt wurden und fügt drei weitere Bereiche (Lebensmittelanalytik, Forensik, Archäozoologie) hinzu, die von den Ergebnissen dieser Untersuchung profitieren können.

\section{Übersicht 2}

\section{Bereich}

Restaurierung, Konservierung und Denkmal- Identifizierung von Fischleim, Kasein, Körnerpflege hautleim, Hasenleim

Technik- und Materialkunde S.o.

Archäozoologie

Pharmazie und Medizin

Anthropologie und Archäologie

Handschriftenkunde und Kodikologie

Lebensmittelanalytik

Forensik

Kunstgeschichte
Schnelle und sichere Speziesbestimmung durch PCR-RFLP

Identifizierung prähistorischer pflanzlicher Inhaltsstoffen (z.B. Salbei)

Identifizierung prähistorischer. Nahrungsbestandteile in Behältern Bestimmung der Funktionalität eines keltischen Beutels.

Spezies- und Individualidentifizierung aus Pergamenten

Verbesserung vorhandener Methoden der Speziesbestimmung durch PCR-RFLP

Ausbreitung des Materialienspektrums auf stark prozessierte Materialien

Speziesbestimmung von Leimen und Bindemitteln 


\section{$7 \quad$ Kurzzusammenfassung}

Im Mittelpunkt der Untersuchungen stand die taxonomische Identifizierung archäologischer und kulturhistorischer Funde und Werkstoffe. Für stark degradierte tierliche DNA wurde dies auf dem Niveau der Spezies durch PCR-RFLP und Sequenzierung mitochondrialer loci (Cytochrom B, 12SrRNA-DNA) umgesetzt. Dabei konnte gezeigt werden, daß kollagene Materialien, wie frühneuzeitliche Pergamente, bronzezeitliche Knochen und rezente Fischleime, unter positiven Erhaltungsbedingungen in vielen Fällen endogene DNA aufweisen. Bei Pergament wirkt sich der Herstellungsprozess in der Regel förderlich auf den DNA-Erhalt aus, während das Gerben von Ledern die DNA der Tierhaut meistens zerstört. Aus prähistorischen süd- und zentralamerikanischen Behältern konnten ebenso wie aus einem keltischen Beutel pflanzliche Chloroplasten-Sequenzen ermittelt werden. Der hierfür benutzte rbcL-locus diskriminierte in einem Fall hinsichtlich des Genus, konnte aber in anderen Fällen nur die Ordnung identifizieren und erwies sich hierdurch als wenig geeignet für systematische Anwendungen an degradierter DNA. Bindemittel in Felsbildern und kleinere archäologische Pflanzen-, Textilund Lederfunde ergaben aufgrund ihrer feuchten Erhaltungsbedingungen bzw. ihrer ungeschützten Oberflächen keine reproduzierbaren Resultate.

Die Charakterisierung boviner Microsatelliten-DNA aus historischen Pergamenten führte zur erstmaligen Erstellung von STR-Genotypen aus prozessierten Materialien. Der Vergleich der historischen Allele mit modernen Allelfrequenzen zeigte, daß die meisten Allele aus den Pergamenten in rezenten Populationen fast ganz abwesend sind.

Die wesentlichen Probleme bei der Analyse degradierter DNA sind Kontaminationen, Mischspuren und die Authentifizierung der Resultate. Kontaminationen durch Bearbeiter konnten durch diskriminierendes Primerdesign ausgeschlossen werden. Mit dem PCR-RFLP wurde ein Protokoll entwickelt, das die Identifizierung selbst stark degradierter Mischspuren ermöglicht. Für die Authentifizierung von aDNA wurde ebenso wie für das Design taxonomisch informativer (semi)universeller Primer ein Kriterienkatalog erstellt. 


\section{Literatur}

Ade-Rademacher D \& Sartorius K (1997) “...wo weder Sonne noch Mond hinscheint...”-Die archäologischen Befunde. In: Archäologische Informationen aus Baden-Würtemberg 36: 1725 .

Altschul SF, Madden TL, Schäffer AA, Zhang J, Zhang Z, Miller W, Lipman DJ (1997) Gapped Blast and PSI-Blast: a new generation of protein database search programs. Nucl. Acids Res. 25: 3389-3402.

Annals of the Missouri Botanical Gardens Vol. 80, 3, 1993.

Austin JJ, Ross AJ, Smith AB, Fortey RA Thomas, RH (1997) Problems of reproducibility - does geological ancient DNA survive in amber-preserved insects? Proc. R. Soc. Lond. B. Biol. Sci. 264: 467-474.

Bada JL, Wang XS, Hamilton H (1999) Preservation of key biomolecules in the fossil record: current knowledge and future challenges. Phil. Trans. R. Soc. Lond. B. 354: 77-87.

Bada JL, Wang XS, Poinar HN, Pääbo S, Poinar GO (1994) Amino acid racemization in amberentombed insects - Implications for DNA preservation. Geochim. Cosmochim. Acta 58: 3131-3135.

Bailey JF, Richards MB, Macauley VA, Colson IB, James IT, Bradley DG, Hedges REM, Sykes BC (1996) Ancient DNA suggests a recent expansion of European cattle from a diverse wild progenitor species. Proc. R. Soc. Lond. B. 263: 1467-1473.

Baldino F Jr, Chesselet MF, Lewis ME (1989) High-resolution in situ hybridization histochemistry. Methods Enzymol. 68:761-777.

Barendse W \& Armitage SM (1994) A genetic linkage map of the bovine genome. Nat. Genet. 6: 227-235.

Bartel A (1998) Die organischen Reste an der bronzenen Schnabelkanne des Keltenfürsten von Glauburg-Glauberg, Wetteraukreis (Grab 1). In: Ein frühkeltischer Fürstengrabhügel am Glauberg im Wetteraukreis, Hessen. Bericht über die Forschungen 1994-1996, S. 68-87. Sonderdruck Germania 75, 2.

Bartlett SE \& Davidson WS (1992) FINS (Forensically Informative Nucleotide Sequencing): a procedure for identifying the animal origin of biological specimens. BioTechniques 12,3: 408-411.

Bocherens H (1997) Isotopic biogeochemistry as a marker of Neandertal diet. Anthropol. Anz. 55: 101-120.

Boehringer Mannheim, PCR applications manual. Mannheim 1995.

Boghosian S, Garp T, Nielsen K (1999) Study of the chemical breakdown of collagen and parchment by Raman Spectroscopy. In: Advanced Study Course of the Royal Danish Acadamy of Fine Arts 1999: 73-88.

Bramanti B \& Pacciani E (1999) Norme per il recupero di resti umani nello scavo archeologico in funzione dell'analisi del DNA. In: Rollo F (Hg.) Il DNA nello studio dei resti umani antichi: principi, metodi, applicazioni, Palermo: 19-29.

Breslauer KJ, Frank R, Blocker H, Marky LA (1986) Predicting DNA duplex stability from the base sequence. Proc. Natl. Acad. Sci. U S A 11: 3746-50.

Buoncristiani M, von Beroldingen C, Sensabaugh GF (1990) Effects of UV damage on DNA amplification by the polymerase chain reaktion. In: Polesky HF \& Mayr WR (Hg.) Advances in Haemogenetics 3. Heidelberg: 151-153.

Burger J \& Großkopf B (1997a) DNA aus Nachgeburtsbestattungen -Molekulare Anthropologie und Archäometrie. Wo weder Sonne noch Mond hinscheint. Archäologische Nachweise von 
Nachgeburtsbestattungen in der Frühen Neuzeit. Archäologische Informationen aus BadenWürttemberg 36: 43-44.

Burger J \& Großkopf B (1997b) DNA in rock art. Tracce 9:78.

Burger J (1997) Erhaltungszustand von DNA aus prähistorischen Zähnen unterschiedlichen Liegemilieus und verschiedener Art der Lagerung. Magisterarbeit Mainz.

Burger J, Großkopf B, Hummel S, Herrmann B (2000c) DNA techniques in archaeometry - News and progress. Proceedings 31st International Symposium on Archaeometry, Budapest 1998, im Druck.

Burger J, Großkopf B, Pfeiffer I, Kahle M, Hummel S, Herrmann B (1998): Paläogenetische Untersuchungen an Pergamenten und Ledern. In: Hauptmann G (Hg.) Archäometrie und Denkmalpflege. Kurzberichte, Bochum 1998: 39-42.

Burger J, Hummel S, Herrmann B (1997) Nachweis von DNA-Einzelkopiesequenzen aus prähistorischen Zähnen. Liegemilieu als Faktor für den Erhalt von DNA. Anthrop. Anz. 55,2: 193198

Burger J, Hummel S, Herrmann B, Henke W (1999a) DNA preservation: A microsatellite-DNA study on ancient skeletal remains. Electrophoresis 20,8:1722-1728

Burger J, Hummel S, Pfeiffer I, Herrmann B (2000a) Palaeogenetic analysis of (pre)historic artifacts and its significance for anthropology. Anthropol. Anz. 58,1, im Druck.

Burger J, Hummel S, Pfeiffer I, Herrmann B (1999b) Ancient DNA from archaeological and historical artefacts. Human Genome Diversity Euroconference, Cambridge. Poster.

Burger J, Pfeiffer I, Hummel S, Fuchs R, Brenig B, Herrmann B (2000d) Mitchondrial and nuclear DNA from (pre)historic hide-derived material. Molecular Ecology, submitted.

Burger J,Hummel S, Herrmann B (2000b) Palaeogenetics and cultural heritage. Species determination and STR genotyping from ancient DNA in art and artefacts. Thermochemica Acta, im Druck.

Burger, J (1999) Extraktion of DNA from leather and parchment. In: Advanced Study Course of the Royal Danish Acadamy of Fine Arts 1999: 121-125.

Burmester A \& Krekel C (1998) Von Dürers Farben. In: Heimberg B, Goldberg G, Schawe M (Hg.) Albrecht Dürer. Die Gemälde der Alten Pinakothek. München.

Cano RJ, Poinar HN, Poinar Jr GO (1992) Isolation and partial characterisation of DNA from the bee Proplebeia dominicana in 25-40 milion year old amber. Med. Sci. Res. 20: 249-251.

Cha RS \& Thilly WG (1995) Specifity, efficiency, and fidelity of PCR. In: Diefenbach CW \& Dveksler GS: PCR Primer. A laboratory manual. Cold Spring Harbor Laboratory Press: $37-$ 51.

Chaffee SD, Hyman M, Rowe MW, Coulam NJ, Schroedl A, Hogue K (1994) Radiocarbon dates on the All American Man pictograph. American Antiquity 59, 4: 769-781.

Cimino G, Metchette K, Isaaks ST, Sheng Zhu Y (1990) more false-positive problems. Nature 345 : 773-774.

Clottes J (1996) Thematic changes in Upper Palaeolithic art: a view from the Grotte Chauvet. Antiquity 70: 276-288.

Collins MJ, Waite ER, Duin ACT (1999) Predicting protein decomposition: the case of asparticacid racemization kinetics. Phil. Trans. R. Soc. Lond. B. 354: 51-64.

Cone RW \& Fairfax MR (1993) Protocol for ultraviolet irradiation of surfaces to reduce PCR contamination. PCR Meth. Appl. 3: 15-17.

Cooper A \& Wayne R (1998) New uses for old DNA. Current opinions in Biotechnology 9: 49-53.

Cooper A, Mourer-Chauviré C, Chambers GK, von Haessler A, Wilson AC, Pääbo S (1992) Independent origins of New Zealand moas and kiwis. Proc. Natl. Acad. Sci, USA 89: 87418744.

Crooijmans RPMA, van der Poel JJ, Groenen MAM (1995) Functional genes mapped on the chicken genome. Anim. Genet. 26: 73-78. 
De Reyer D, Pilbout S, Dennebouy N, Monnerot M (2000) Medieval textiles: Ancient DNA and analyses of metal threads made of animal substrate. Proceedings 31st International Symposium on Archaeometry, Budapest 1998, im Druck.

DeReyer D, Pilbout S, Dennebouty N, Monnerot M (1997) Cultural properties and molecular biology: gold threads on Medieval textiles. Conference Ancient DNA IV, June 1997, Goettingen.

DeSalle R, Gatesy J, Wheeler W, Grimaldi D (1992) DNA sequences from a fossil termite in Oligo-Miocene amber and their phylogenetic implications. Science 257: 1933-1936.

Diefenbach CW \& Dveksler GS: PCR Primer. A laboratory manual. Cold Spring Harbor Laboratory Press 1995.

Dobiat C \& Stoellner T (1997) Siedlungs- und Wirtschaftsgeschichte des Dürrnberges bei Hallein. Vorbericht zu den Gelände- und Laborforschungen des Ausgrabungsjahres 1996. Arch. Korrbl. 27: 583-599.

Dobiat C, Stoellner T, Boenke N, Burger J, Buthmann N, Gawlick HJ, Hummel S, Herrmann B, Megaw V, Morgan G, Posselt M, Roettger K, Zickgraf B (2000) Siedlungs- und Wirtschaftsgeschichte des Duerrnberges bei Hallein. Vorbericht zu den Gelände- und Laborforschungen des Ausgrabungsjahres 1998/1999. Arch. Korrbl. 30,1, 2000, im Druck.

Doran GH, Dickel DN, Ballinger WEJ, Agee OF, Laipis PJ, Hauswirth WW (1986) Anatomical, cellular, and molecular analysis of 800-year-old human brain tissue from the Windover archaeological site. Nature 323: 803-806.

Downs EF \& JM Lowenstein (1995) Identification of archaeological blood proteins: a cautionary note. J. Archaeological Sci. 22: 11-16.

Ede AJ, Pierson CA, Crawford AM (1994) Ovine microsatellites at the OarCP34, OarCP38, OarCP43, OarCP49, OarCP73, OarCP79 loci. Anim. Genet. 26: 130-131.

Eglinton G \& Logan GA (1991) Molecular preservation. Phil. Trans. R. Soc. Lond. B. 333: $315-$ 328.

Eglinton G, The archaeological and geological fate of biomolecules. In: Greenblatt CL (Hg.) Digging for pathogens. Ancient emerging diseases-their evolutionary, anthropological and archaeological context. Balaban publishers, Rehovot/Israel 1997: 299-327.

Engelke DR, Hoener PA, Collins FS (1988) Direct sequencing of enzymatically amplified human genomic DNA. Proc. Natl. Acad. Sci. USA 85,2: 544-548.

Erlich HA (Hg.) PCR technology. Principles and applications for DNA amplification. New York 1989.

Evershed RP, Dudd SN, Charters S, Mottram H, Stott AW, Raven A, van Bergen PF, Bland HA (1999) Phil. Trans. R. Soc. Lond. B. 354: 19-31.

Fabig A (1998) Die Rekonstruktion der Ernährungsgrundlage als Möglichkeit der Differenzierung zwischen berufs- und ernährungsbedingten Elementeinträgen in das Skelett am Beispiel einer Bergbaubevölkerung. Eine methodenorientierte Untersuchung an Knochenproben und Nahrungsmitteln. Diplomarbeit Göttingen.

Fiedel SJ (1996) Blood from stones? Some methodological and interpretive problems in blood residue analysis. J. Archaeological Sci. 23: 139-147.

Findlay I, Taylor A, Quirke P, Frazier R, Urquhart A (1997) DNA fingerprinting from single cells. Nature 389: 555-556.

Flindt S (1996) Die Lichtensteinhöhle bei Osterode, Ldkr. Osterode am Harz. Eine Opferhöhle der jüngeren Bronzezeit im Gipskarst des südwestlichen Harzrandes. Berichte zur Denkmalpflege Niedersachsen 2: 41-43.

Fuchs R (1991) Der widerspenstigen Zähmung - Pergament in Geschichte und Struktur. In : Rück P (Hg.) Pergament. Geschichte, Struktur, Restaurierung, Herstellung. Sigmaringen 1991: 263-277.

Gerstenberger J, Hummel S, Herrmann B (1998) Assignment of an isolated skeletal element to the skeleton of Duke Christian II. Ancient Biomolecules 2: 63-68. 
Gillespie R (1997) On human blood, rock art and calcium oxalate: further studies on organic carbon content and radiocarbon age of materials relating to Australian rock art. Antiquity 71: 430-437.

Golenberg EM, Giannasi DE, Clegg MT, Smiley CJ, Durbin M, Henderson D, Zurawski G (1990) Chloroplast DNA sequences from a miocene Magnolia species. Nature 344: 656-658.

Goodman MF (1995) DNA polymerase fidelity: Misinsertions and mismatched Extensions. In: Innis MA, Gelfand DH, Sninsky JJ, PCR strategies. San Diego: 17-31.

Greenwood AD, Capelli C, Possnert G, Pääbo S (1999) Nuclear DNA Sequences from Late Pleistocene Megafauna. Mol. Bio. Evol. 16,11: 1466-1473.

Großkopf B \& Burger J (1997) Applications of DNA analysis in archaeometry. Meeting ancient DNA IV, Göttingen

Hagelberg E, Sykes B, Hedges R (1989) Ancient bone DNA amplified. Nature 342: 485

Handt O, Krings M, Ward RH, Pääbo S (1996) The retrieval of ancient human DNA sequences Am. J. Hum. Genet. 59: 368-376.

Hardy B (1997) Mammalian aDNA from palaeolithic stone tools. Conference Ancient DNA IV, June 1997, Goettingen.

Hardy BL, RA Raff, V Raman (1997) Recovery of mammalian DNA from Middle Paleolithic stone tools. J. Archaeological Sci. 24: 601-611.

Hardy C, Casane JD, Vigne JD, Callou C, Dennebouy N, Mounolou J-C, Monnerot M, (1994) Ancient DNA from bronze age bones of european rabbit (Oryctolagus cuniculus). Experientia 50: 564-570.

Heidemann E (1991) Das verhalten der Haut bei der pergamentherstellung - interpretiert aus der Biophysik und Biochemie ihrer Struktur. In: Rück P (Hg.) Pergament. Geschichte, Struktur, Restaurierung, Herstellung. Sigmaringen 1991: 221-228.

Herrmann B \& Hummel S (Hg.) Ancient DNA. Recovery and analysis of genetic material from paleontological, archaeological, museum, medical, and forensic specimen. New York 1994.

Herrmann B (Hg.) Archäometrie. Naturwissenschaftliche Analyse von Sachüberresten. Heidelberg 1994.

Higuchi R, Bowman B, Freiberger M, Ryder OA, Wilson AC (1984) DNA sequences from the quagga, an extinct member of the horse family. Nature 312: 282-284.

Hillis DM, Moritz C, Mable BK (Hg.) Molecular Systematics. Sunderland, USA 1996.

Hodgins G (1999) Dissertation, Newcastle, UK.

Hodgins G, DeSalle R, McGlinchey C (1995) Isinglass DNA: identifiyng the animal species origin of glues found in art and artefacts. Conference Ancient DNA III, July 1995, Oxford.

Horai S, Hayasaka K, Murayama K, Wate M, Koike H, Nakai N (1989) DNA amplification from skeletal remains and their sequence analysis. Proc. Jpn. Acad. 65: 229-233.

Höss M, Jaruga P, Zastwany TH, Dizdaroglu M, Pääbo S (1996) DNA damage and DNA sequence retrieval from ancient tissues. Nucl. Acids Res. 24,7: 1304-1307.

Hummel S \& Herrmann B (1991) Y-chromosome-specific DNA amplified in ancient human bone. Naturwissenschaften 78: 266-267.

Hummel S \& Schultes T (2001) From skeletons to fingerprints. STR typing of ancient DNA. Ancient Biomolecules, im Druck.

Hummel S (1994): DNA aus alten Geweben. In: Herrmann B (Hg.) Archäometrie. Naturwissenschaftliche Analyse von Sachüberresten. Springer, Heidelberg 1994: 87-100.

Hummel S, Bramanti B, Schultes T, Kahle M, Haffner S, Herrmann B (2000) Megaplex DNA typing can provide strong indication of the authenticity of ancient DNA amplifications by clearly recognizing any possible type of modern contamination. Anthrop. Anz. 58, im Druck. 
Hummel S, Herrmann B, Rameckers J, Müller D, Sperling K, Neitzel H, Tönnies H (1999b) Proving authenticity of ancient DNA by Comparative Genome Hybridization. Naturwissenschaften 86: 500-503.

Hummel S, Nordsiek G, Rameckers J, Lassen C, Zierdt H, Baron H, Herrmann B (1995) aDNA Ein neuer Zugang zu alten Fragen. Z. Morph. Anthrop. 81: 41-65.

Hummel S, Schultes T, Bramanti B, Herrmann B (1999a) Ancient DNA profiling by megaplex amplifications. Electrophoresis 20: 1717-1721.

Hunan medical college (1980) Study of an ancient cadaver in Mawangtui Tomb No. 1 of the Han Dynasty in Changsha. Beijing:Ancient Memorial Press: 184-187.

Hyland DC, Tersak JM, Adovasio JM, Siegel MI (1990) Identification of the species of origin of residual blood on lithic material. American Antiquity 55, 1: 104-112.

Ilger WA, Hyman M, Southon J, Rowe MW (1996) Radiocarbon dating of ancient rock paintings. Archaeological Chemistry ?: 401-414.

Innis MA \& Gelfand DH (1990) Optimization of PCRs. In: Innis MA, Gelfand DH, Sninsky JJ, White JW (Hg.) PCR protocolls. A guideline to methods and applications. San Diego: 3-12.

Innis MA, Gelfand DH, Sninsky JJ, White JW (Hg.): PCR protocolls. A guideline to methods and applications. San Diego 1990.

Irwin DM, Kocher TD, Wilson (1991) Evolution of the cytochrome b gene of mammals. J. Mol. Evol. 32: 128-144.

Jacobsen W, Der Klosterplan von St. Gallen und die karolingische Architektur. Berlin 1992.

Johnson PH, Olson CB, Goodman M (1985) Isolation and characterization of deocyribonucleic acid from the tissue of the woolly mammoth. Mammuthus primigenius. Comp. Biochem. Physiol. 81B,4: 1045-1051. (Wurde bereits 1981 Auf den Paleopathology Association meetings, Detroit vorgetragen)

Kahila Bar-Gal G, Woodward SR, Smith P, Broshi M, Zias J, Greenblatt C (1995) Analysis of ancient parchment from the Judean Desert using DNA techniques. Conference Ancient DNA III, July 1995, Oxford.

Kaukinen J \& Varvio SL (1993) Eight poymorphic bovine microsatellites. Anim. Genet. 24: 148.

Kimpton C, Gill P, Walton A, Urquhart A, Millican ES, Adams M (1993) Automated DNA profiling employing multiplex amplifications of short tandem repeat loci. PCR Meth. Applicat. 3: 13-22.

Kimpton C, Walton A, Gill P (1992) A further tetranucleotide repeat polymorphism in the vWF gene. Hum. Mol. Gen. 1,4: 287.

Kimura B, Hardy BL, Brandt SA, Hauswirth WW (1997) Analysis of DNA from ethnoarchaeological stone scrapers. Conference Ancient DNA IV, June 1997, Goettingen.

Kocher TD, Thomas WK, Meyer A, Edwards SV, Pääbo S, Villablanca FX, Wilson AC (1989) Dynamics of mitochondrial DNA evolution in animals: Amplification and sequencing with conserved primers. Proc. Natl. Acad. Sci. USA, 86: 6196-6200.

Koller J \& Baumer U (1998) Fette und fette Öle in Malschichten: Tricks und Tücken bei der Analyse. In: Hauptmann A (Hg.) Archäometrie und Denkmalpflege. Kurzbericht. Jahrestagung Würzburg 1998: 49-54.

Krajewski C, Driskell AC, Baverstock PR, Braun MJ (1992) Phylogenetic relationship of the thylacine (Mammalia:Thylacinidae) among dasyuroids marsupials: evidence from cytochrome b DNA sequences. Proc. R. Soc. Lond. B. Biol. Sci. 250, 1327: 19-27.

Krekel C \& Burmester A (1998) Die Preise von Düreres Farben: Ultramarin und Azurit. In: Hauptmann A (Hg.) Archäometrie und Denkmalpflege. Kurzbericht Jahrestagung Würzburg 1998: 75-77.

Krings M, Geisert H, Schmitz RW, Krainitzki H, Paabo S (1999) DNA sequence of the mitochondrial hypervariable region II from the neandertal type specimen. Proc Natl Acad Sci U S A, 96,10: 5581-5. 
Krings M, Stone A, Schmitz R-W, Krainitzki H, Stoneking M, Pääbo S (1997) Neandertal DNA sequences and the origin of modern humans. Cell 90: 19-30.

Larsen R, Barkholt V, Nielsen K (1989) Amino Acid Analysis of leather. Preliminary studies in deterioration, accelerated ageing and conservation of vegetable tannes leather. Das Leder: 153-158.

Lassen C, Hummel S, Herrmann B (1994) Comparison of DNA extraction and amplification from ancient human bone and soft tissue. Int. J. Leg. Med. 107: 152-155.

Lee LG, Spurgeon SL, Heiner CR, Benson SC, Rosenblum BB, Menchen SM, Graham RJ, Constantinescu A, Upadhya KG, Cassel JM (1997) New energy transfer dyes for DNA sequencing. Nucl. Acids Res. 25: 2816-2822.

Lindahl T (1993) Instability and decay of the primary structure of DNA. Nature 362: 709-715.

Litt M, Hauge XY, Sharma V (1993) Shadow bands seen when typing polymorphic dinucleotid repeats: Some causes and cures. BioTechniques 15: 280-284.

Loreille O, Vigne JD, Hardy C, Callou C, Treinen-Claustre F, Dennebouy N, Monnerot M (1997) First distinction of sheep and goat archaeological bones by the means of their fossil mtDNA. J. Archaeological Sci. 24: 33-37.

Loy TH \& Hardy B (1992) Blood residue analysis of 90.000 year old stone tools from Tabun Cave, Israel. Antiquity 88: 24 -35.

Loy TH \& Matthaei KI (1994) Species of origin determination from prehistoric blood residues using ancient genomic DNA. Australas. Biotechnol. 4, 3: 161-162.

Loy TH (1983) Prehistoric blood residues: detection on tool surfaces and identification of species of origin. Science 220: 1269-71.

Loy TH (1990) Prehistoric organic residues: recent advances in identification, dating and their antiquity. In: Archaeometry. Proceedings of the 27th international symposium in Archaeometry, Heidelberg 1990: 645-656.

Loy TH (1993) The artifact as site: an example of the biomolecular analysis of organic residues on prehistoric tools. World Archaeologoy 25, 1: 44-63.

Loy TH, Jones R, Nelson DE, Meethan B (1990) Accelerator radiocarbon dating of human blood proteins in pigments from Late Pleistocene art sites in Australia. Antiquity 64: 110-116.

Marota I, Luciani S, Ubaldi M, Basile C, Rollo F (1997) DNA analysis of ancient papyri: a quantitave approach. Conference Ancient DNA IV, June 1997, Goettingen.

Meyer R, Höfelein C, Lüthy J, Candrian U (1995) Polymerase Chain Reaction-Restriction fragment length polymorphisms analysis: a simple method for species identification in food. Journal of AOAC International 78,6: 1542-1551.

Moore SS \& Byrne K (1994) Characterisation of 65 bovine microsatellites. Mamm. Genome 5: 8490.

Nelson DE (1991) A new method for carbon isotope analysis of protein. Science 251: 552-554.

Niehaus C \& Gehrmann P (1991) PCR: Kontamination und deren Vermeidung. BioTechniques 2: 48-49.

Olmstead RG \& Palmer JD (1992) A chloroplast DNA phylogeny of the Solanaceae: Subfamilial relationships and character evolution. Ann. Missouri Bot. Garden 79: 346-360.

Olmstead RG \& Palmer JD (1994) Chloroplast DNA systematics: A review of methods and data analysis. Am. J. Bot. 81: 1205-55.

Pääbo S (1984) Über den Nachweis von DNA in altägyptischen Mumien. Das Altertum 30,4 : 213 218.

Parry DV \& Ricks SD (Hg.) Current research and technological developments on the Dead sea Scrolls. Leiden 1996.

Pfeiffer I \& Brenig B (1998) A highly polymorphic microsatellite within intron 5 of the porcine 54/56 kDA vacuolar H(+)-ATPase subunit gene (V-ATPase). Animal Genetics 29: 464-465. 
Pfeiffer I, Burger J, Brenig B (1999) Microsatellite typing of ancient parchment and leather. Annual meeting of EAAP, Zürich, Aug. 1999 (Poster).

Plath A, Krause I Einspannier R (1997) Species identification in dairy products by three different DNA-based techniques. Z. Lebensm. Unters. Forsch. A. 205: 437-441.

Poinar HN \& Stankiewicz BA (1999) Protein preservation and DNA retrieval from ancient tissues. Proc. Natl. Acad. Sci. USA 96: 8426-8431.

Poinar HN, Hofreiter M, Spaulding WG, Martin PS, Stankiewcz BA, Bland H, Evershed RP, Possnert G, Pääbo S (1998) Molecular Coproscopy: Dung and Diet of the Extinct ground sloth Nothrotheriops shastensis. Science 281: 402-406.

Poinar HN, Höss M, Bada JL, Pääbo S (1996) Amino acid racemization and the preservation of ancient DNA. Science 272: 864-866.

Polymeropoulos MH, Rath DS, Xia H, Merril CR (1991) Tetranucleotide repeat polymorphism at the human c-fes/fps proto-oncogen. Nucl. Acids Res. 19,14: 4018.

Rameckers J, Hummel S, Herrmann B (1997) How many cycles does a PCR need? - Determination of cycle numbers depending on the number of targets and the reaction efficiency factor. Naturwissenschaften 84: 259-262.

Rasmussen SB, Bechmann D, Nielsen K (1999) Detection of radicals in collagen and parchment produced by natural and artificial deterioration, electron paramagnetic resonance spectroscopy (EPR) and its implications for artificial ageing and test of conservtion. In: Advanced Study Course of the Royal Danish Acadamy of Fine Arts 1999: 89-100.

Rebel E, Albrecht Dürer. Maler und Humanist München 1999.

Reed R \& Poole JB (1964) A study of some Dead Sea Scroll and leather fragments from cave 4 at Qumran part II. Chemical examination. Proceedings of the Leeds Philosophical and Literary Society 1964: 171.

Reed R: Ancient Skins, parchments, and leathers. London 1972.

Reese RL, M Hyman, MW Rowe, JN Derr, SK Davis (1996) Ancient DNA from Texas Pictographs. J. Archaeological Sci. 23: 269-277.

Rolfs A, Schuller I, Finck U, Weber-Rolfs I: PCR: Clinical diagnostics and research. Berlin 1992.

Rölleke S, Gurtner C, Drewello U, Lubitz W, Weissmann R (1999) Analysis of bacterial communities on historical glass by denaturing gradient gel electrophoresis of PCR-amplified gene fragments coding for 16S rRNA. J. Microbiol. Methods 36,1-2: 107-114.

Rölleke S, Muyzer G, Wawer C, Wanner G, Lubitz W (1996) Identification of Bacteria in a biodegraded wall painting by denaturing gradient gel electrophoresis of PCR-amplified gene fragments coding for 16S rRNA. Applied and Environmental Microbiology 62, 6: 2059-65.

Rösch M (1998) Pollenanalyse an einem eisenzeitlichen Gefäßinhalt aus eiem keltischen Fürstengrab am Glauberg in Hessen. In: Ein frühkeltischer Fürstengrabhügel am Glauberg im Wetteraukreis, Hessen. Bericht über die Forschungen 1994-1996, Sonderdruck Germania 75,2: 89-96.

Rück P (Hg.) Pergament. Geschichte, Struktur, Restaurierung, Herstellung. Sigmaringen 1991.

Rychlik (1995b) Selection of primers for polymerase chain reaction. Mol. Biotechnol. 3,2: 129134.

Rychlik W (1995a) Priming efficiency in PCR. Biotechniques 18,1: 88-90.

Rychlik W, Spencer WJ, Rhoads RE (1990) Optimization of the annealing temperature for DNA amplification in vitro. Nucl. Acids Res. 18,21: 6409-12.

Saiki RK (1989) The design and optimization of the PCR. In: Erlich HA (ed): PCR technology. Principles and Applications for DNA Amplification. New York: 7-16.

Saiki RK, Scharf SJ, Faloona F, Mullis KB, Horn GT, Erlich HA, Arnheim N (1985) Enzymatic amplification of beta-globin genomic sequences and restriction analysis for diagnosis of sickle-cell anemia. Science 230: 1350-54. 
Sanger F, Nicklen S , Coulson AR (1977) DNA sequencing with chain-terminating inhibitors. Proc Natl Acad Sci USA 74: 5463.

Schmerer WM (1996) Reproduzierbarkeit von Microsatelliten-DNA-Amplifikation und Alleldetermination aus bodengelagertem Skelettmaterial. Diplomarbeit Göttingen.

Schmerer, W.M., Hummel, S., and Herrmann, B. (1999) Optimized DNA extraction to improve reproducability of short tandem repeat genotyping with highly degraded DNA as target. Electrophoresis 20: 1712-1716.

Schmidt T \& Schram J (1998) Antiquarische Bücher als Senke luftgetragener Schadstoffe. In: Hauptmann, A (Hg.) Archäometrie und Denkmalpflege . KurzberichtJahrestagung Würzburg 1998: 52-54.

Schmidt T (1995) Aufdeckung von Kontaminationsquellen durch Amplifikation hochrepetitiver DNA-Sequenzen. Diplomarbeit, Göttingen.

Schmidt T, Hummel S, Herrmann B (1995) Evidence of contamination in PCR-laboratory disposables. Naturwissenschaften 82: 423-431.

Schultes T, Hummel S, Herrmann B (1997a) Zurodnung isolierter Skelettelemente mittels aDNAtyping. Anthrop. Anz. 55: 207-216.

Schultes T, Hummel S, Herrmann B (1997b) Recognizing and overcoming inconsistencies in microsatellite typing of ancient DNA samples. Anc. Biomol. 1: 227-233.

Schultes T, Hummel S, Herrmann B (1999) Amplification of Y-chromosomal STRs from ancient skeletal material. Hum. Gen. 10: 164-166.

Schutkowski H (1995) What you are makes you eat different things - interrelations of diet, status, and sex in the early medieval population of Kirchheim unter Teck, FRG. Hum. Evol. 10: 119-130.

Schwarcz HP \& Schoeninger MJ (1991) Stable isotope analyses in human nutritional ecology. Yearb. Phys. Anthrop. 34: 283-321.

Simon C, Pääbo S, Kocher TD Wilson AC (1990) Evolution of mitochondrial ribosomal RNA in insects as shown by the polymerase chain reaction. In: Clegg M, O'Brian S (Hg.) Molecular Evolution. UCLA Symposium on Molecular and Cellular Biology, New Series, Vol. 122. New York 1990: 235-244.

Smith LM, Sanders JZ, Kaiser RJ, Hughes P, Dodd C, Connell CR, Heiner C, Kent SBH, Hood 1 (1986) Fluorescence detection in automated DNA sequence analysis. Nature 321: 674-678.

Smith P R \& Wilson MT (1992) Blood residues on ancient tool surfaces: a cautionary note. J. Archaeological Sci. 19: 237-242.

Smith P R \& Wilson, MT (1990) Detection of haemoglobin in human skeletal remains by ELISA. J. Archaeological Sci. 17: 255-268.

Soltis DE, Clegg MT, Durbin M (1990) rbcL sequence divergence and phylogenetic relationships in the Saxifragaceae sensu lato. Proc. Natl. Acad. Sci. USA 87: 4640-44.

Soltis PS, Soltis DE, Smiley CJ (1992) An rbcL sequence from a Miocene Taxodium (bald cypress). Proc. Natl. Acad. Sci. USA 89: 499-451.

Stoellner T \& Dobiat C (1998) Keltische Salzmetropole. Arch. Deutschland 1: 6-11.

Sykes B (1997) Really ancient DNA. Lights turning red on amber. Nature 386: 764-765.

Thomas WK, Pääbo S, Villablanca FX, Wilson AC (1990) Spatial and temporal distribution of kangaroo rat populations shown by sequencing mitochondrial DNA from museum specimens. J. Mol. Evol. 31: 101-112.

Thorne RT (1992) Classification and geography of the flowering plants. Botanical review 58: 225238.

Tite MS, Methods of physical examination in archaeology. London 1972.

Valladas H, Cachier H, Arnold M (1990) AMS C-14 dates for the prehistoric Cougnac cave paintings by selective oxidation of organic carbon. Nature 348: 710-711. 
Van Der Merwe NJ, Sealy J, Yates R (1987) First accelerator carbon-14 date from a rock painting. South African Journal of Science 83: 56-57.

Vargas Sanders R \& Zayil Salazar C (2000) A study of migration in Mexican prehispanic populations by DNA analysis. Proceedings 31st International Symposium on Archaeometry, Budapest 1998, im Druck.

Walsh PS, Metzger DA, Higuchi R (1991) Chelex ${ }^{\circledR} 100$ as a medium for simple extraction of DNA for PCR-based typing from forensic material. Biotechniques 10,4: 506-513.

Ward R \& Stringer C (1997) A molecular handle on the Neanderthals. Nature 17, 388: 225-226.

Weber JL \& May PE (1989) Abundant class of human polymorphisms wich can be typed using the polymerase chain reaction. Am. J. Hum. Genet. 44: 388-396.

Wess T (1999) Analysis of collagen structure in parchment by small angle x-ray diffraction. In: Advanced Study Course of the Royal Danish Acadamy of Fine Arts 1999: 127-135.

Woodward SR, Kahila G, Smith P, Greenblatt C, Zias J, Broshi M, in: Perry DW \& Ricks S (Hg.) Current research and technological developments on the Dead Sea scrolls. Leiden 1996: 215-238.

Zierdt H (1995) Amplifikation von Mikrosatelliten-DNA aus Knochen- und Zahnproben zur Verwandschaftsrekonstruktion einer frühmittelalterlichen Bevölkerung. Diplomarbeit Göttingen. 


\section{Anhang}

\subsection{Einheiten und Abkürzungen}

\begin{tabular}{|c|c|}
\hline $\begin{array}{l}\% \\
\text { (®) }\end{array}$ & $\begin{array}{l}\text { Prozent } \\
\text { rechtlich geschützt }\end{array}$ \\
\hline${ }^{\circ} \mathrm{C}$ & Grad Celsius \\
\hline$\mu 1$ & Microliter \\
\hline$\%$ & Promille \\
\hline 6-FAM & 6-Carboxylfluorescein \\
\hline Abb. & Abbildung \\
\hline abs & absolut \\
\hline $\mathrm{AD}$ & anno domini \\
\hline aDNA & ancient DNA (alte DNA) \\
\hline APS & Ammoniumpersulfat \\
\hline $\mathrm{BP}$ & before present (engl. vor heute) \\
\hline bp & Basenpaar(e) \\
\hline bzw. & beziehungsweise \\
\hline ca. & circa, ungefähr \\
\hline $\mathrm{cm}$ & Zentimeter \\
\hline cpDNA & Chloroplasten DNA \\
\hline d.h. & das heißt \\
\hline ddNTPs & Didesoxinucleotidtriphosphate \\
\hline DNA & Desoxiribonucleic Acid (Desoxiribonucleinsäure) \\
\hline dNTPs & Desoxinucleotidtriphosphate \\
\hline EDTA & Ethylendiamintetraacetat \\
\hline et al. & et alii \\
\hline fmol & Femtomol \\
\hline $\mathrm{g}$ & Gramm \\
\hline $\mathrm{h}$ & Stunde \\
\hline HCL & Salzsäure \\
\hline HEX & 6-Carboxyl-2', 4', 7', 4, 7-Hexachlorofluorescein \\
\hline $\mathrm{Hg}$. & Herausgeber \\
\hline Kap. & Kapitel \\
\hline $\mathrm{Kb}$ & Kilobasenpaare \\
\hline 1 & Liter \\
\hline M & molar \\
\hline $\max$. & maximal \\
\hline $\min$ & Minute(n) \\
\hline $\mathrm{ml}$ & Milliliter \\
\hline $\mathrm{mM}$ & millimolar \\
\hline mol & Mol \\
\hline \multicolumn{2}{|c|}{ mtDNAmitochondriale DNA } \\
\hline n.d. & non determinandum (nicht zu bestimmen) \\
\hline $\mathrm{NaAc}$ & Natriumacetat \\
\hline ncDNA & nukleare DNA \\
\hline ng & Nanogramm \\
\hline $\mathrm{nm}$ & Nanometer \\
\hline p.a. & pro analysei \\
\hline PAGE & Polyacrylamidgelelektrophorese \\
\hline PCR & Polymerase Chain Reaktion \\
\hline
\end{tabular}




$\begin{array}{ll}\text { pg } & \text { Picogramm } \\ \text { pH } & \text { pondus Hydrogeni, Protonenaktivitätsexponent } \\ \text { pM } & \text { picomolar } \\ \text { pmol } & \text { Picomol } \\ \text { pp. } & \text { Seiten } \\ \text { RFLP } & \text { Restriktions-Fragment-Längen-Polymorphismus } \\ \text { ROX } & \text { 6-Carboxylrhodamin } \\ \text { RT } & \text { Raumtemperatur } \\ \text { s } & \text { Sekunde(n) } \\ \text { s.o. } & \text { siehe oben } \\ \text { STR } & \text { Short Tandem Repeat } \\ \text { Tab. } & \text { Tabelle } \\ \text { Taq-Polymerase } \\ \text { TB } & \text { Tris-Borat-Puffer } \\ \text { TBE } & \text { Tris-Borat-EDTA-Puffer } \\ \text { TEMED } & \text { N, N, N', N'Tetramethylethylendiamin } \\ \text { TF } & \text { Tris-Formiat-Puffer } \\ \text { Tris } & \text { Tri[hydroxymethyl]aminomethan } \\ \text { rm } & \text { Trade Mark (Warenzeichen) } \\ \text { U } & \text { Unit, Einheit für Enzymaktivität } \\ \text { U/min } & \text { Umdrehung pro Minute } \\ \text { UV } & \text { Ultraviolett } \\ \text { V } & \text { Volt } \\ \text { v. Chr. } & \text { vor Christi Geburt } \\ \text { vgl. } & \text { vergleiche } \\ \text { w/v } & \text { weight per volume (Gewicht pro Volumen) } \\ \text { x } & \text { mal } \\ \text { z.B. } & \text { zum Beispiel } \\ & \end{array}$

\subsection{Verwendete Gräte, Chemikalien und Kits}

\section{Geräte}

Bidestillationsanlage Typ 1071, Köttermann

Dentalbohrmaschine Typ K10, 1000-40000 U/min, EWL

Digital-pH-Meter Typ 646 mit Standard Glaselektrode, Knick

DNA-Extraktor GenePure Typ 341A, Applied Biosystems

DNA-Sequenzer Modell 310 und 373A stretch mit 672 GENESCAN-ANALYSIS software und 672 GENESCAN-COLLECTION software zur Fragmentlängenanalyse, Applied Biosystems

DNA Thermal Cycler Typ TC1, Perkin Elmer Cetus

Elektrophoresekammern Horizon 1060BD 5.8 (5x8 cm), Gibco BRL

Elektrophoresekammern Horizon 1060BD 11.14 (11x14 cm), Gibco BRL

Elektrophoresekammern, Maxigel Typ G48, 16x20 cm, vertikal, Biometra

Kugelschwingmühle Typ MM2, mit Zirkonium-Mahlbechern, Retsch

Magnetrührer Ikamag ${ }^{\circledR}$ RET, Ikamag ${ }^{\circledR}$ MTC, Ikamag ${ }^{\circledR}$ RH, Janke \& Kunkel Ika-Werk Matrixdrucker iDP-560RS, Secoman

Polaroid $_{\text {тм }}^{\text {TM }}$-Film, ISO $3000^{\circ}$, Typ 667, Polaroid ${ }_{\text {тм }}^{\text {тм }}$

Polaroid ${ }^{\mathrm{TM}}$-Kamera, MP4 Land Camera, Polaroid ${ }^{\mathrm{TM}}$ mit Orangefilter Typ 15 für Ethidiumbromidfärbung, Polaroid 
Präzisionswaage excellence Typ E 1200S, Sartorius

Rotator (Eigenbau), $15 \mathrm{U} / \mathrm{min}$

Schüttelapparat, Typ 3011, GFL

Stromversorgung Typ P25, 400V/1000 mA, Biometra

Stromversorgung Typ ST504 Electrophoresis Power Supply, Gibco BRL

Stromversorgung Typ ST606 Electrophoresis Power Supply, Gibco BRL

Thermomixer Typ 5437, Eppendorf

Thermostat Typ 5320, Eppendorf

Transilluminator Typ IL-350K, 254 nm, Bachofer

Trockenschrank, Memmert

UV-Handlampen Typ UVK-12, $254 \mathrm{~nm}$, Neolab

UV-Spektralphotometer Typ S.750, Secoman

Varipetten $^{\circledR}$ Typ 4810, Satz: 0,5-10 $\mu 1,10-100 \mu 1,50-250 \mu 1,500-2500 \mu 1$, Eppendorf

Zentrifuge Typ 5402, Eppendorf

Zentrifuge Typ 5415C, Eppendorf

\section{Chemikalien}

1 Kb DNA-Leiter (Molekulargewichtslängenstandard), Life Technologies

2 x Lyse-Puffer, DNA purification grade, Applied Biosystems

Acrylamid/Bisacrylamid 29:1, 40\% (w/v), Amresco ${ }^{\circledR}$

Acryl-Glide Glass Plate Coating, Amresco ${ }^{\circledR}$

Agarose UltraPure , electrophoresis grade, Gibco BRL

Agarose, analytical grade for DNA electrophoresis, Serva

Alconox (Detergenz), Aldrich

Ammoniumpersulfat, ACS grade, Amresco

AmpFlSTR ${ }^{\circledR}$ Blue ${ }^{\mathrm{TM}}$ Allelic Ladder, 5-FAM markiert, D3S1358 (Allel 12-19), vWA (Allel 11-21), FGA (Allel 18-30), Perkin Elmer Applied Biosystems

AmpFlSTR ${ }^{\circledR}$ Green $^{\text {TM }}$ II Allelic Ladder, JOE markiert, Amelogenin (Allel X, Y), D8S1179

(Allel 8-19), D21S11 (Allel 24.2-38), D18S51 (Allel 9-26), Perkin Elmer Applied

Biosystems

AmpFlSTR ${ }^{\circledR}$ PCR Reaktionsmix, $\left(\mathrm{MgCl}_{2}\right.$, dATP, dGTP, dCTP, dTTP, BSA, Natriumacetat $[0,05 \%])$, Perkin Elmer Applied Biosystems

AmpFlSTR ${ }^{\circledR}$ Profiler Plus ${ }^{\mathrm{TM}}$ Primer Set, Primer für die Loci D3S1358 (5-FAM), vWA (5-

FAM), FGA (5-FAM), D8S1179 (JOE), D21S11 (JOE), D18S51 (JOE), D5S818

(NED), D13S317 (NED), D7S820 (NED) und Amelogenin (JOE), Perkin Elmer Applied Biosystems

AmpFlSTR $^{\circledR}$ Yellow $^{\text {TM }}$ Allelic Ladder, NED markiert, D5S818 (Allel 7-16), D13S317

(Allel 8-15), D7S820 (Allel 6-15), Perkin Elmer Applied Biosystems

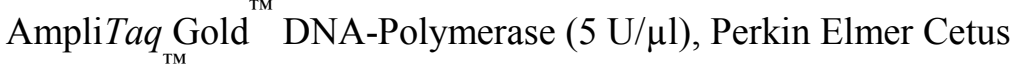

AmpliTaq DNA-Polymerase (5 U/ $\mu \mathrm{l})$, Perkin Elmer Cetus

Ampuwa (steriles Wasser), Fresenius

Aqua bidestilata, eigene Herstellung

Borsäure, p.a., Merck

Bromphenolblau Natriumsalz, p.a., Serva

Chelex ${ }^{\circledR} 100$ Resin, Bio-Rad

Chloroform, DNA purification grade, Applied Biosystems

CTAB Isolations Puffer, $2 \%, \mathrm{pH} 8,0$,

dATP, dCTP, dGTP, dTTP, Boehringer

Dextran-Blau, Fluka 
EDTA (Ethylendinitrotetraacetat Dinatriumsalz-Dihydrat): Titriplex ${ }^{\circledR}$ III, Merck Ethanol absolut, p.a., Abgabestellen der Bundesmonopolverwaltung: Zander-Göttingen, Nordbrand-Nordhausen (Abfüllung Universitätsklinikumsapotheke Göttingen)

Ethidiumbromid, wässrige Lösung 1\%(w/v), $10 \mathrm{mg} / \mathrm{ml}$, Serva

Extran $^{\circledR}$ Typ AP13 alkalisch mit Detergenzien, Merck

Fluoreszenzfarbstoff SYBR ${ }^{\text {TM }}$ Green I, Nucleic Acids Gel Stain (S-7567), Molecular

Probes, MoBiTec

Formamid, Sigma

GeneAmp ${ }^{\circledR} 10$ x PCR Buffer II \& $\mathrm{MgCl}_{2}$ Solution $25 \mathrm{mM}$, Perkin Elmer Cetus

GeneAmp ${ }^{\circledR} 10 \times$ PCR Buffer, Perkin Elmer Cetus

GENESCAN-350 ROX-Kit (spurinterner Standard, loading buffer), Applied Biosystems

Glasmilk $^{\circledR}$ Typ Geneclean ${ }^{\circledR}$, Bio 101, Dianova

Harnstoff, Gibco BRL

Hexadecylmethylammoniumbromid (CTAB), Merck-Suchardt

Isopropanol, p.a., Merck

LS V (Molekulargewichtslängenstandard), Boehringer Mannheim

Mineralöl NUJOL, Perkin Elmer Cetus

Natriumacetatpuffer, $2 \mathrm{M}, \mathrm{pH}$ 4,5, DNA purification grade, Applied Biosystems

Natriumhydroxyd Plätzchen, p.a., Merck

Phenol:Chloroform:Wasser (70:16:14), DNA purification grade, Applied Biosystems

Proteinase K, DNA purification grade, Applied Biosystems

Proteinase K, Qiagen

QIAshredder, Qiagen

Salpetersäuer, $\mathrm{HNO}_{3}, 65 \%$, p.a., Merck

Salzsäure rauchend, $\mathrm{HCl}, 37 \%$, Merck

TEMED (Tetramethylethylendiamin), Amresco ${ }^{\circledR}$

TEMED (Tetramethylethylendiamin), Fluka

Tris (Tri[hydroxymethyl]aminoethan), Trizma ${ }^{\mathrm{T} M}$ Base, p.a., Sigma

\section{Einwegmaterialien und Hilfsmittel}

Dental-Diamantsägeblätter Typ Diaflex-TH350 220, Horico

Einmaluntersuchungshandschuhe Peha ${ }^{\circledR}$-safe, Peha ${ }^{\circledR}$-soft, Hartmann

Eppendorf Reaktionsgefäße $(0,5 \mathrm{ml})$ safe-lock, Eppendorf

Eppendorf Reaktionsgefäße $(2,0 \mathrm{ml})$ safe-lock, Eppendorf

GeneAmp ${ }^{\circledR}$ PCR-Reaktionsgefäße $(0,5 \mathrm{ml})$, Perkin Elmer Cetus

Gesichtsmasken: Surgine face mask, Johnson \& Johnson

Kimwipes ${ }^{\circledR}$ Präzisionstücher, Kimberley-Clark

Kleenex ${ }^{\circledR}$ Tücher, Kimberley-Clark

Microcon ${ }^{\text {TM }}$ Ultrakonzentratoren 10.000, 30.000, und 50.000 MWCO, entspricht 30, 60

und 125 NCO für ssDNA, Amicon

Parafilm $^{\circledR} \mathrm{M}$, American National Can

PE-Zentrifugationsgefäße, BlueMax ${ }_{\text {тм }}^{\text {тм }} 15 \mathrm{ml}$ Conical Tubes 2070, Falcon ${ }_{\mathbb{B}}^{\circledR}$

PE-Zentrifugationsgefäße, BlueMax ${ }^{\text {TM }} 50 \mathrm{ml}$ Conical Tubes 2070, Falcon

Pipettenspitzen: blaue Spitzen $1 \mathrm{ml}$, Sarstedt

Pipettenspitzen: gelbe Spitzen $100 \mu 1$, Sarstedt

Pipettenspitzen: Standardtips $10 \mu 1$, Eppendorf

Pipettenspitzen: Standardtips 2,5 ml, Eppendorf 
Präzipitetten: 13mm Precipitette -II Cardridge, Applied Biosystems

Sterilfiltrationseinheiten, $0,2 \mu \mathrm{m}$ Membran, Nalgene

Längenstandards Agarosegellektrophorese

$1 \mathrm{~Kb}$ Leiter, Life Technologies

(Größen in bp)

$\begin{array}{llllllllll}75 & 134 & 154 & 201 & 220 & 298 & 344 & 396 & 506 & 517 \\ 1018 & 1636 & 2036 & 3054 & 4072 & 5090 & 6108 & 7126 & 8144 & 9162\end{array}$

$\begin{array}{lll}10180 & 11198 \quad 12216\end{array}$

LS V Leiter, Boehringer Mannheim

(Größen in bp)

$\begin{array}{llllllllll}8 & 11 & 18 & 21 & 51 & 57 & 64 & 80 & 89 & 104 \\ 123 & 124 & 184 & 192 & 213 & 234 & 267 & 434 & 458 & 504 \\ 540 & 587 & & & & & & & & \end{array}$

$\underline{\text { Kits }}$

Profiler Plus Kit, PE Biosystems

Dneasy Plant Kit, Qiagen

QIAamp Tissue Kit, Qiagen

QIAquick, Qiagen

Wizard PCR Prep DNA Purification System, Promega 


\subsection{Eigene Publikationen}

\section{Journale mit review}

Burger J, Hummel S, Herrmann B (1997) Nachweis von DNAEinzelkopiesequenzen aus prähistorischen Zähnen. Liegemilieu als Faktor für den Erhalt von DNA. Anthrop Anz 55,2:193-198.

Burger J, Hummel S, Herrmann B, Henke W (1999) DNA preservation: A microsatellite-DNA study on ancient skeletal remains. Electrophoresis 20,8:1722-1728.

Burger, J, Hummel, S, Pfeiffer, I, Herrmann, B (2000a) Palaeogenetic analysis of (pre)historic artifacts and its significance for anthropology. Anthropol. Anz., 58,1,69-76.

Burger J, Pfeiffer I, Hummel S, Fuchs R, Brenig B, Herrmann B: Mitochondrial and nuclear DNA from (pre)historic hide-derived material. Ancient Biomolecules, im Druck.

Burger, J, Schoon, R, Zeike, B, Hummel, S, Herrmann, B: Species determination using species-discriminating PCR-RFLP of ancient DNA from prehistoric skeletal remains. Ancient Biomolecules, im Druck.

Burger J, Hummel S, Herrmann B (2000b) Palaeogenetics and cultural heritage. Species determination and STR genotyping from ancient DNA in art and artefacts. Thermochemica Acta 365,1-2: 141-146.

\section{Journale ohne review}

Burger J \& Großkopf B (1997) DNA aus Nachgeburtsbestattungen -Molekulare Anthropologie und Archäometrie. Wo weder Sonne noch Mond hinscheint. Archäologische Nachweise von Nachgeburtsbestattungen in der Frühen Neuzeit. Archäologische Informationen aus Baden-Württemberg 36: 43-44.

Burger J, Großkopf B, Hummel S, Herrmann B (1998) DNA techniques in archaeometry - News and progress. Proceedings 31st International Symposium on Archaeometry, Budapest 1998, im Druck.

Burger J \& Großkopf, B (1997) DNA in rock art. Tracce 9:78.

Dobiat C, Stoellner T, Boenke N, Burger J, Buthmann N, Gawlick HJ, Hummel S, Herrmann B, Megaw V, Morgan G, Posselt M, Roettger K, Zickgraf B (2000) Siedlungs- und Wirtschaftsgeschichte des Duerrnberges bei Hallein. Vorbericht zu den Gelände- und Laborforschungen des Ausgrabungsjahres 1998/1999. Arch. Korrbl. 30,1: 65-84.

Hummel S, Burger J, Lassen C, Rameckers J, Schultes T, Herrmann B (1996) DNA typing of highly degraded DNA from human teeth and bone samples by Multiplex PCR. Amplifications 14:7+20. 
Hummel S, Burger J, Rameckers J, Lassen C, Schmerer W, Herrmann B (1996)

Improvement of short tandem repeat amplifications of highly degraded DNA from human teeth and bone samples. Amplifications 14(1):5-6.

\section{Konferenzbeiträge mit Abstract}

Bramanti B, Burger J, Herrmann B, Hummel S, Rollo FU, Vernesi C, Ardito G, Chiarelli B (1997) Analisi genetica di popolazioni storiche. Gli Etruschi. Antropologia Contemporanea. XII Congresso Ass. Antropol Ital., Palermo-Alia Sept. 97.

Burger J, Großkopf B, Hummel S, Herrmann B (1997) DNA in rock art. 2nd International Congress of Rupestrian Archaeology, Valcamonica.

Burger J \& Großkopf B (1998) DNA-Analyse kulturhistorischer Objekte. Tagung Gesellschaft für Anthropologie, Göttingen.

Burger J, Großkopf B, Hummel S, Herrmann B (1998) DNA techniques in archaeometry - News and progress. 31st International Symposium on Archaeometry, Budapest.

Burger J, Großkopf B, Hummel S, Pfeiffer I, Kahle M, Herrmann B (1998) Paläogenetische Untersuchungen an Pergamenten und Ledern. Jahrestagung Archäometrie, Würzburg.

Burger J, Hummel S, Henke W, Herrmann B (1999) Ancient Microsatellite DNA Preservation. 5th international DNA fingerprinting conference, Port Elizabeth.

Burger J, Hummel S, Herrmann B (1999) Gene aus der Vergangenheit. Molekulargenetische Untersuchungen an archäologischen Artefakten. 3. Deutscher Archäologenkongreß Heidelberg.

Burger J, Hummel S, Herrmann B (1999) Palaeogenetics of archaeological artefacts. European Archaeological Association Conference, Bournemouth, UK, 14.-19.09.1999.

Burger J, Pfeiffer I, Hummel S, Herrmann B (1998) DNA in parchment and leather. 4th contractors meeting, MAP, Offenbach.

Burger J, Pfeiffer I, Hummel S, Herrmann B (1999) Ancient Microsatellite DNA in animal skin. MAP-meeting, Prag.

Burger J, Pfeiffer I, Hummel S, Herrmann B (1999) Animal skin, DNA, and archaeology. World archaeological congress, Kapstadt.

Burger J, Großkopf B, Pfeiffer I, Kahle M, Hummel S, Herrmann B (1998) Paläogenetische Untersuchungen an Pergamenten und Ledern. In: Hauptmann $\mathrm{G}$ (Hg.) Archäometrie und Denkmalpflege - Kurzberichte. Bochum 1998.

Burger J, Pfeiffer I, Hummel S, Herrmann B (1999) The (high) potential for ancient DNA analysis from animal skin. 5th international DNA fingerprinting conference, Port Elizabeth. 
Burger J, Hummel S, Herrmann B(1999) Ancient Microsatellite DNA Preservation, 5th international DNA fingerprinting conference, Port Elizabeth.

Burger J \& Großkopf B (1998) DNA-Analyse kulturhistorischer Objekte. Homo 49/Suppl.:13

Burger J, Pfeiffer I, Hummel S, Herrmann B (1999) Animal skin, DNA, and archaeology. World archaeological congress 4, Internetveröffentlichung.

Burger J, Hummel S, Herrmann B (1999) Palaeogenetics of Archaeological Artefacts. Meeting European Archaeological Association. Bournemouth.

\section{Poster}

Burger J, Hummel S, Pfeiffer I, Herrmann B (1999) Ancient DNA from archaeological and historical artefacts. Human Genome Diversity Euroconference, Cambridge.

Großkopf B, Burger J (1997) Applications of DNA analysis in archaeometry. Meeting ancient DNA IV, Göttingen.

Großkopf B, Burger J, Pfeiffer I, Hummel S, Herrmann B (1998) DNA in parchment and leather. 31st International Symposium on Archaeometry, Budapest.

Hummel S, Schultes T, Burger J, Herrmann B (1999) Determining kinship by ancient DNA analysis. European Archaeological Association Conference, Sep. 1999, Bournemouth,UK.

Pfeiffer I, Burger J, Brenig B (1999) Microsatellite typing of ancient parchment and leather. Annual meeting of EAAP, Zürich, Sep. 1999.

\section{Ausstellungen}

Genwelten. Leben aus dem Labor? Ausstellung Landesmuseum für Technik und Arbeit, Mannheim Mai-Juni 1997.

\section{Beiträge in Lehrbüchern}

Burger J, Extraktion of DNA from leather and parchment. In: Advanced Study Course of the Royal Danish Acadamy of Fine Arts 1999, 121-125.

Burger J Hummel S, Herrmann B, Palaeogenetics of parchment. In: Wouters J \& Larsen R. (ed.) Micromethods in the analysis of parchment, im Druck. 


\section{Danksagung}

Ich danke Herrn Professor Dr. Bernd Herrmann und Frau Dr. Susanne Hummel für die Ermöglichung dieser Arbeit und ihre inhaltliche Unterstützung.

Dem Bundesministerium für Bildung und Forschung und dem Forschungszentrum Jülich, namentlich Herrn Dr. Krebs und Herrn Dr. Husemann, sei für die finanzielle Unterstützung gedankt.

Für vieljährigen guten Rat und freundschaftliche Hilfe danke ich Tobias Schultes.

Ich danke Frau Dr. Ina Pfeiffer und Herrn Rainhold Schoon für erfolgreiche Zusammenarbeit. Frau Melanie Kahle, Frau Birgit Zeike, Frau Cadja Lassen, Herrn Alexander Fabig, Frau Ruth Bollongino, Frau Simone Haffner, Frau Birgit Großkopf, Frau Sibylle Hourticolon und Herrn Eberhard George danke ich für tatkräftige Unterstützung.

Bei Götz Frömming, Wolfram Brinker, Ekkehard May, Oliver Hill und Barbara Bramanti bedanke ich mich nicht nur für ihr wissenschaftliches Vorbild.

Für ihre Kooperationsbereitschaft und für das Bereitstellen von Proben bedanke ich mich bei Frau Dr. Maria Gaida, Staatliche Museen zu Berlin, Preussischer Kulturbesitz, Museum für Völkerkunde, Herrn Professor Robert Fuchs, Fachhochschule Köln, Restaurierung und Konservierung von Kunst- und Kulturgut, Frau Solveig Turpin und Herrn Jim Zintgraf, Herrn Professor Marvin Rowe, Department of Chemistry, Texas A\&M University, College Station, USA, Frau Roberta McGregeor, Witte Museum, San Antonio, USA, Frau Dr. Renate van Issem, Handschriften- und Restaurationsabteilung der Staats- und Universitätsbibliothek Göttingen, Herrn Axel Treptau, Bayerisches Nationalmuseum, München, Herrn Professor Bertram Brenig, Tiergenetik, Universität Göttingen, Herrn Professor Charles Greenblatt, The Kuvin Centre for the Study of Infectous Tropical Diseases, The Hebrew University Jerusalem, Israel, Herrn Dr. Fritz-Rudolf Hermann und Herrn Will, Landesdenkmalamt Hessen, Wiesbaden Biebrich, Herrn Professor Hartmut Stegemann, Theologische Fakultät der Georg August Universität Göttingen, Abteilung Antikes Judentum, Herrn Dr. J. Koller, Bayerische Staatsgemäldesammlung, Doerner Institut, München, Herrn Dr. Jan Wouters, Royal Institute for Artistic Heritage, Brüssel, Belgien, Herrn Dr. René Larsen, Det Kongelige Danske Kunstakademi, Konservatorskolen, Kopenhagen, dem Niedersächsisches Landesamt für Ökologie, Hannover und Herrn Dr. Thomas Stöllner, Vorgeschichtliches Seminar der Philipps-Universität Marburg.

Nicht zuletzt gilt mein besonderer und herzlichster Dank meinen Eltern und meiner Tante Coletta. 


\section{Curriculum Vitae}

\section{von Joachim Anton Burger}

geboren am 27. 06. 1969 in Aschaffenburg

Staatsangehörigkeit: deutsch

1988

$1988-1990$

$1991-96$

1994-95

1996

1997

1997- 2000

\author{
Abitur am Kronberg-Gymnasium in Aschaffenburg \\ Zivildienst in Aschaffenburg \\ Studium der Anthropologie an der Johannes Gutenberg-Universität \\ Mainz
}

Studium der Molekulargenetik und Biochemie an der Universität Glasgow. Projektarbeit am dortigen Institut für Gerichtsmedizin.

Magisterarbeit an der Universität Göttingen am Institut für Anthropologie eingereicht zu Erlangung des Magister Artium in Anthropologie 1997 an der Johannes Gutenberg-Universität in Mainz. Titel der Arbeit: „Erhaltungszustand von DNA aus prähistorischen Zähnen unterschiedlichen Liegemilieus und unterschiedlicher Art der

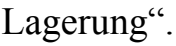

Aufnahme des Promotionsprojekts „Alte DNA aus archäologischen Funden und historischen Werkstoffen“ im Rahmen des Vorhabens „Biowissenschaftliche Archäometrie. DNA-Analysen von kulturhistorischen Objekten“.

Wiss. Angestellter am Institut für Zoologie und Anthropologie Göttingen.

Göttingen, im März 2000

Joachim Burger 